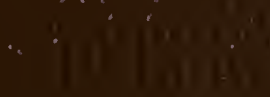


MRR 191979 






\title{
FLORA OF GUATEMALA
}

\author{
PART IX
}





\section{FLORA OF GUATEMALA}

PAUL C. STANDLEY

Late Curator of the Herbarium

Field Museum of Natural History

LOUIS O. WILLIAMS

Chairman, Department of Botany

Field Museum of Natural History

AND

DOROTHY N. GIBSON

Supervisor of the Herbaria

Field Museum of Natural History

FIELDIANA: BOTANY

VOLUME 24, PART IX, NUMBERS 1-4

Published by

FIELD MUSEUM OF NATURAL HISTORY

1970-1973 
The research on Part IX of the "Flora of Guatemala" was made possible through generous grants from the National Science Foundation to Field Museum of Natural History, Louis $\mathrm{O}$. Williams, principal investigator.

Library of Congress Catalog Card Number: 48-3076

PRINTED IN THE UNITED STATES OF AMERICA

BY FIELD MUSEUM PRESS 


\section{FLORA OF GUATEMALA}

PAUL, C. STANDLEY

AND

LOUIS O. WILLIAMS

JAN 191979

BIOLOGY LIRRARY
101 BURRILL HALL

The Librarv of the

JAN 181979

at Urbana-Lhampatgin

FIELDIANA: BO'TANY

VOLUME 24, PART IX, NUMBERS 1 AND 2

Published by

FIELD MUSEUM OF NATURAL HISTORY

JUNE 26, 1970 



FLORA OF GUATEMALA

PART IX 


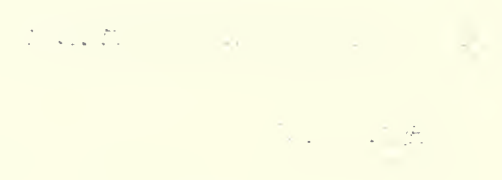




\title{
FLORA OF GUATEMALA
}

\author{
PAUL C. STANDLEY
}

The Late Curator of the Herbarium

AND

LOUIS O. WILLIAMS

Chief Curator, Botany

\author{
FIELDIANA: BOTANY \\ VOLUME 24, PART IX, NUMBERS 1 AND 2 \\ Published by \\ FIELD MUSEUM OF NATURAL HISTORY \\ JUNE 26, 1970 \\ PUBLICATION 1100
}


Library of Congress Catalog Card Number: 48-3076

PRINTED IN THE UNITED STATES OF AMERICA

BY FIELD MUSEUM PRESS 
Leaves not scale-like, chlorophyll present; sometimes parasites (or saprophytes).

Leaves opposite.

Flowers zygomorphic.

Stamens the same number as the corolla lobes.

Stigma one.

Ovule one in each locule

Solanaceae.

Ovules more than one in each locule.

Ovules two or more in each locule.

Locule one. Boraginaceae.

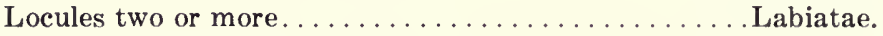

Ovules numerous in each locule.

Placentation axile.......... Solanaceae and Scrophulariaceae.

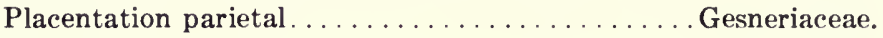

Stigmas two or more.

Ovule one in each locule.

Locule one. ...................... Pedaliaceae.

Locules two or more.

Corolla lobes imbricate.

Verbenaceae.

Corolla valvate or contorted

Polemoniaceae.

Ovules more than one in each locule.

Ovules two or more in each locule.

Locule one.

Corolla lobes imbricate.

Pedaliaceae.

Corolla valvate or contorted.

Acanthaceae.

Locules two or more.

Polemoniaceae.

Ovules numerous in each locule.

Corolla lobes imbricate.

Locule one.........Pedaliaceae and Scrophulariaceae (rare). Locules two........... Scrophulariaceae and Polemoniaceae. Corolla valvate, convolute or contorted.

Locule one. Acanthaceae.

Locules two or more

Polemoniaceae.

Stamens not the same number as the corolla lobes.

Stigma one.

Ovule one in each locule.

Solanaceae.

Ovules more than one in each locule.

Ovules two or more in each locule. Labiatae.

Ovules numerous in each locule.

Placentation axile.

Locule one.........Pedaliaceae and Scrophulariaceae (rare).

Locules two or more................. Scrophulariaceae.

Placentation parietal. ................ Gesneriaceae.

Stigmas two or more.

Ovule one in each locule.

Locule one. . ....................... Pedaliaceae.

Locules two or more................... Verbenaceae.

Ovules more than one in each locule.

Ovules two or more in each locule.

Corolla lobes imbricate.

Pedaliaceae. 
Corolla lobes valvate.

Acanthaceae.

Ovules numerous in each locule.

Placentation axile.

Corolla lobes imbricate.

Locule one........ Pedaliaceae and Scrophulariaceae (rare). Locules two or more

Scrophulariaceae and Bignoniaceae (rare).

Corolla valvate, convolute, or contorted ......... Acanthaceae.

Placentation parietal.... Martyniaceae and Bignoniaceae (rare).

Flowers actinomorphic.

Stigma one.

Ovule one in each locule.

Solanaceae.

Ovules more than one in each locule.

Ovules two or more in each locule.

Locule one.......................... Boraginaceae.

Locules two or more . . . . . . . . . . . . . . . . . . . . . Labiatae.

Ovules numerous in each locule.

Placentation axile..................... Solanaceae.

Placentation parietal.

Sepals valvate. . . . . . . . . . . . . . . . . Gesneriaceae.

Sepals imbricate..... Hydrophyllaceae and Gesneriaceae (rare).

Stigmas two or more.

Corolla lobes imbricate.................... Verbenaceae.

Corolla lobes valvate. .................. Polemoniaceae.

Leaves alternate.

Flowers zygomorphic.

Stamens same number as corolla lobes.

Stigma one.

Ovule one in each locule. . . . . . . . . . . . . . . Solanaceae.

Ovules more than one in each locule.

Ovules two or more in each locule............. Boraginaceae.

Ovules numerous in each locule.

Placentation axile........... Solanaceae and Scrophulariaceae.

Placentation parietal. ................. Gesneriaceae.

Stigmas two or more.

Corolla lobes valvate.................... Polemoniaceae.

Corolla lobes imbricate. . . . . . . . . . . . . . . . Scrophulariaceae.

Stamens not the same number as the corolla lobes.

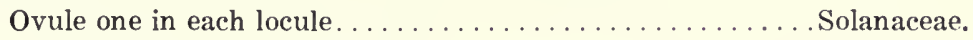

Ovules numerous in each locule

Solanaceae, Scrophulariaceae and Lentibulariaceae.

Flowers actinomorphic.

Stigma one.

Ovule one in each locule........... Solanaceae and Convolvulaceae.

Ovules more than one in each locule.

Ovules two or more in each locule. . Boraginaceae and Convolvulaceae.

Ovules numerous in each locule.

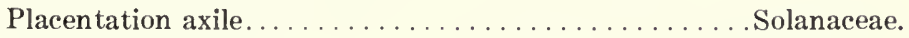

Placentation parietal. ........ Hydrophyllaceae and Gesneriaceae. 
Stigmas two or more.

Corolla lobes imbricate. Verbenaceae and Convolvulaceae.

Corolla lobes not imbricate.

Corolla lobes plicate-contorted . . . . . . . . . . Convolvulaceae.

Corolla lobes valvate................... Polemoniaceae.

\section{EXCEPTIONS}

\section{Families of Tubiflorae in Which Compound Leaves May Occur.}

Stamens the same number as the corolla lobes.

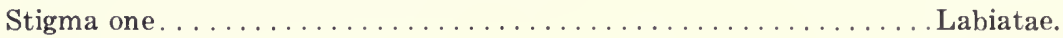

Stigmas two or more.

Corolla lobes imbricate........................ Verbenaceae.

Corolla lobes valvate...................... Polemoniaceae.

Stamens not the same number as the corolla lobes.

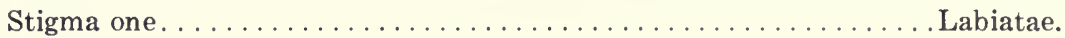

Stigmas two or more.

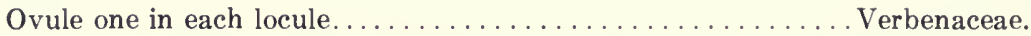

Ovules numerous in each locule................... Bignoniaceae.

II. Families of Tubiflorae in Which Inferior Ovaries May Occur.

Stigma one; parietal placentation . . . . . . . . . . . . . Gesneriaceae.

Stigmas two or more; axile placentation................ Pedaliaceae.

III. Families of Tubiflorae in Which the Stamens May Be Connate (mostly by anthers).

Stigma one.

Ovule one in each locule.

Ovules numerous in each locule.

Placentation axile.

Solanaceae.

Placentation parietal

Solanaceae and Scrophulariaceae.

Stigmas two or more.

Corolla lobes imbricate.............. Scrophulariaceae and Bignoniaceae.

Corolla lobes valvate, convolute, contorted.................

IV. Families of Tubiflorae in Which Unisexual Flowers May Occur.

Stigma one.

Corolla lobes convolute, plicate-contorted ............ Convolvulaceae.

Corolla lobes imbricate. . . . . . . . . Boraginaceae and Convolvulaceae.

Stigmas two or more.............. Verbenaceae and Convolvulaceae.

V. Family of Tubiflorae in Which Stipules or Pseudostipules May Occur.

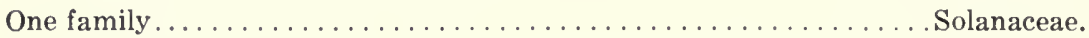

\section{CONVOLVULACEAE. Morning Glory family}

Paul C. Standley and Louis O. Williams

Herbs, vines (usually twining), shrubs or rarely trees, the sap usually milky; leaves simple but of ten lobate, pinnate or pectinate, or reduced to scales in Cuscuta, 
estipulate; inflorescence axillary, the flowers solitary or in dichasia, heads or pancles; flowers perfect, regular or slightly zygomorphic, of ten large and showy but ugaceous; sepals 5, free, imbricated, equal or not, usually persistent and of ten accrescent in fruit, corolla sympetalous, tubular, funnelform, campanulate or salverform, the limb with 5 lobes or teeth or almost entire, often induplicate in bud and with distinctly limited longitudinal midpetaline areas or stripes; anthers 5 , listinct, inserted on the base of the corolla tube and alternate with the lobes, linear or oblong, 2-celled, introrse; disc annular or cupular, sometimes 5-lobate, or none; ovary superior, mostly 2-3-celled and each cell biovulate, or 4-6-celled and the cells uniovulate, rarely 1-celled with 4 ovules; the ovary of 2-4 almost free carpels; tyle filiform, simple or bifid or with 2 distinct styles; stigma capitate or bilobate or the stigmas 2 and globose, ellipsoid or linear; fruit 4-1-celled, usually capsular and dehiscent by valves, rarely transversely or irregularly dehiscent or indehiscent; seeds of ten fewer than the ovules, of ten pubescent, with sometimes scanty but very ard endosperm.

The Convolvulaceae, world wide but most numerous in the tropics' contains some 40 or 50 genera. The largest of these genera is Ipomoea which contains some $300-400$ species, which are often common and showy in Central America in both dry and wet regions. Ipomoea batatas, the sweet potato, is one of the important food plants in the tropies of the world. It is commonly grown in Central America. Several members of this family are grown as ornaments and numerous weeds occur in the family. One other genus, Stictocardia, is known in Central America.

The family is much in need of critical revision. It is a natural one and the genera are not easy to delimit. Most of the work on the Convolvulaceae in recent years has been carried out by the brilliant Argentine botanist Carlos Alberto O'Donell (1912-1954). Posthumous works published in Lilloa (29: 19-376. 1959) indicate 0 'Donell's thinking along generic lines. It was a great tragedy that this man of such great promise died so young.

Plants slender twining parasites, without any green coloring, the stems yellow or

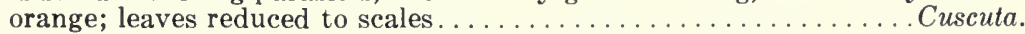
Plants not parasitic, the leaves green and normally developed.

Ovary and fruit deeply bilobate, or the carpels distinct; small creeping plants with minute flowers; leaves reniform, sericeous beneath....... Dichondra. Ovary and fruit entire, not lobate.

Fruits indehiscent, somewhat baccate or dry, or dehiscent but the seeds surrounded by orange-colored pulp; woody vines.

Leaves cordate or subcordate at the base; seeds usually 1 ; corolla white.

Leaves obtuse or acute at the base.

Turbina.

Fruit indehiscent; flowers purple, $3.5-5 \mathrm{~cm}$. long; leaves glabrous beneath

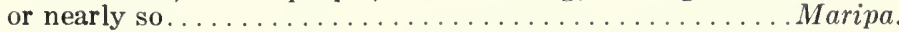

Fruit dehiscent; flowers greenish, $1 \mathrm{~cm}$. long; leaves densely sericeous

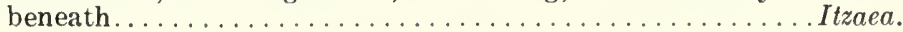


Fruit dehiscent, dry; seeds never surrounded by pulp.

Style 1 and bifid, or the styles 2 and distinct.

Plants scandent, woody; styles bifid; stigmas capitate

Plants not scandent, herbaceous, small; styles 2; stigmas elongate.

Style 1, entire.

Sepals very unequal, the outer ones much broader and concealing the inner ones, ovate, green; herbaceous vines; leaves obtuse or acute at the base; flowers white................... Aniseia.

Sepals subequal, or but slightly unequal, the outer ones of ten shorter or narrower than the inner.

Stigmas elliptic or oblong; small or large vines, the flowers usually small..............................Jacquemontia.

Stigmas globose or biglobose.

Capsule transversely dehiscent................ Operculina. Capsule opening by vertical valves.

Stamens and style exserted.

Corolla salverform, white or blue........... Calonyction.

Corolla funnelform or tubular, rarely salverform, red, orange, yellow, bronze, or greenish............ Quamoclit.

Stamens and style not exserted.

Pollen smooth; herbaceous vines; flowers yellow or white.

Merremia.

Pollen echinate; plants various in habit, of ten woody; flowers various in color, most of ten blue or purple, rarely white or yellow........................ Ipomoea.

\section{ANISEIA Choisy}

Plants herbaceous, prostrate or scandent; leaves linear to ovate or elliptic, of ten mucronate, entire; flowers small, axillary, solitary or in few-flowered dichasial inflorescences; sepals 5, herbaceous, unequal, the 3 outer ones larger, of ten decurrent on the pedicel; corolla funnelform, the limb 5-dentate or subentire, with 5 longitudinal pubescent stripes outside; stamens and style included; ovary glabrous, 2-celled, the cells bi-ovulate; disk small or none; style 1, slender, the stigma biglobose; capsule globose, 2-celled, 4-valvate, 4-seeded.

About five species, one in the Old World tropics, the others American. One other species is known from southern Central America.

Aniseia cernua Moric. Pl. Nouv. Amer. 56. 1838; Standl. \& Steyerm. Field Mus. Bot. 22: 270. 1940. Jacquemontia chiapensis Brandeg. Univ. Calif. Publ. Bot. 6: 60. 1914.

Wet thickets or wet meadows bordering lakes, $800 \mathrm{~m}$. or less; Jutiapa; Escuintla. Southern Mexico; British Honduras; El Salvador; Honduras; South America.

A slender herbaceous vine, the stems prostrate and rooting or usually twining, appressed-pilose; leaves narrowly oblong or linear-lanceolate, $3-10 \mathrm{~cm}$. long, 1.5 
$\mathrm{cm}$. broad or narrower, acute or rounded and mucronate at the apex, acute at the base, somewhat fleshy when fresh, appressed-pilose with whitish hairs or glabrate, short-petiolate; peduncles axillary, mostly 1-flowered, shorter than the leaves; bracts linear, 2-4 mm. long; sepals appressed-pilose, the 3 outer ones ovate, acute or acuminate, broadly rounded or subcordate at the base, 9-13 $\mathrm{mm}$. long, the 2 inner ones ovate, acuminate; corolla white, $1.5 \mathrm{~cm}$. long or larger; capsule $2 \mathrm{~cm}$. long; seeds black, glabrous.

Called "bejuco de pescado" in El Salvador, the tough stems being used there for stringing fish. A. martinicensis (Jacq.) Choisy and its var. nitens (Choisy) O'Donell occur in Central America.

\section{BONAMIA Petit-Thouars}

Reference: Tin Myint \& Daniel B. Ward, A taxonomic revision of the genus Bonamia, Phytologia 17: 121-239, figs. 1968.

Herbaceous or woody vines, or the plants sometimes prostrate and not twining, glabrous or pubescent; leaves entire; flowers cymose, the cymes axillary and short-pedunculate, sometimes forming a terminal panicle, the bracts small, sepals obtuse or rarely acute, subequal or the outer ones larger and orbicular-cordate; corolla campanulate, the limb plicate, 5 -angulate, stamens shorter than the corolla, the filaments filiform, often dilated at the base, the anthers oval or oblong; ovary 2 celled, 4-ovulate, the style filiform, bifid, or the styles 2 and free, the stigmas capitate; capsule globose or ovoid, 4-valvate, membranaceous or coriaceous; seeds 4 or by abortion fewer, glabrous or pilose.

Species about 45 , in tropical regions of both hemispheres. Only three species have been found in Central America.

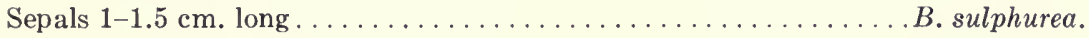
Sepals $0.4-0.5 \mathrm{~cm}$. long . . . . . . b.

Bonamia brevipedicellata Myint \& Ward, Phytologia 17: 188, fig. 1968.

Forest edges and clearings, near sea level, endemic, Machaca, British Honduras (type Schipp 1210).

Woody vines to $15 \mathrm{~m}$. or more long and $2-3 \mathrm{~cm}$. in diameter. Leaves elliptic to ovate-elliptic, acute or acuminate, rounded or obtuse at the base, $8-12 \mathrm{~cm}$. long and 4-7 cm. broad, glabrous above, densely puberulent below, the petioles $2-3 \mathrm{~cm}$. long; inflorescence axillary, a compact many-flowered cyme, up to $10 \mathrm{~cm}$. long or perhaps more with short pedicels to $3 \mathrm{~mm}$. long; sepals subequal, ovate-orbicular, 4-5 mm. long and 3-4 mm. broad, densely puberulent; corolla campanulate with a narrow cylindrical tube, $1-1.2 \mathrm{~cm}$. long, hirsute on the interplicae; stamens included; styles free to the base, subequal, $1 \mathrm{~cm}$. long or less, stigmas peltate subglobose.

Bonamia sulphurea (Brandegee) Myint \& Ward, Phytologia 17: 178. 1968. Breweria sulphurea Brandegee, Univ. Cal. Publ. Bot. 4: 384.1913. 


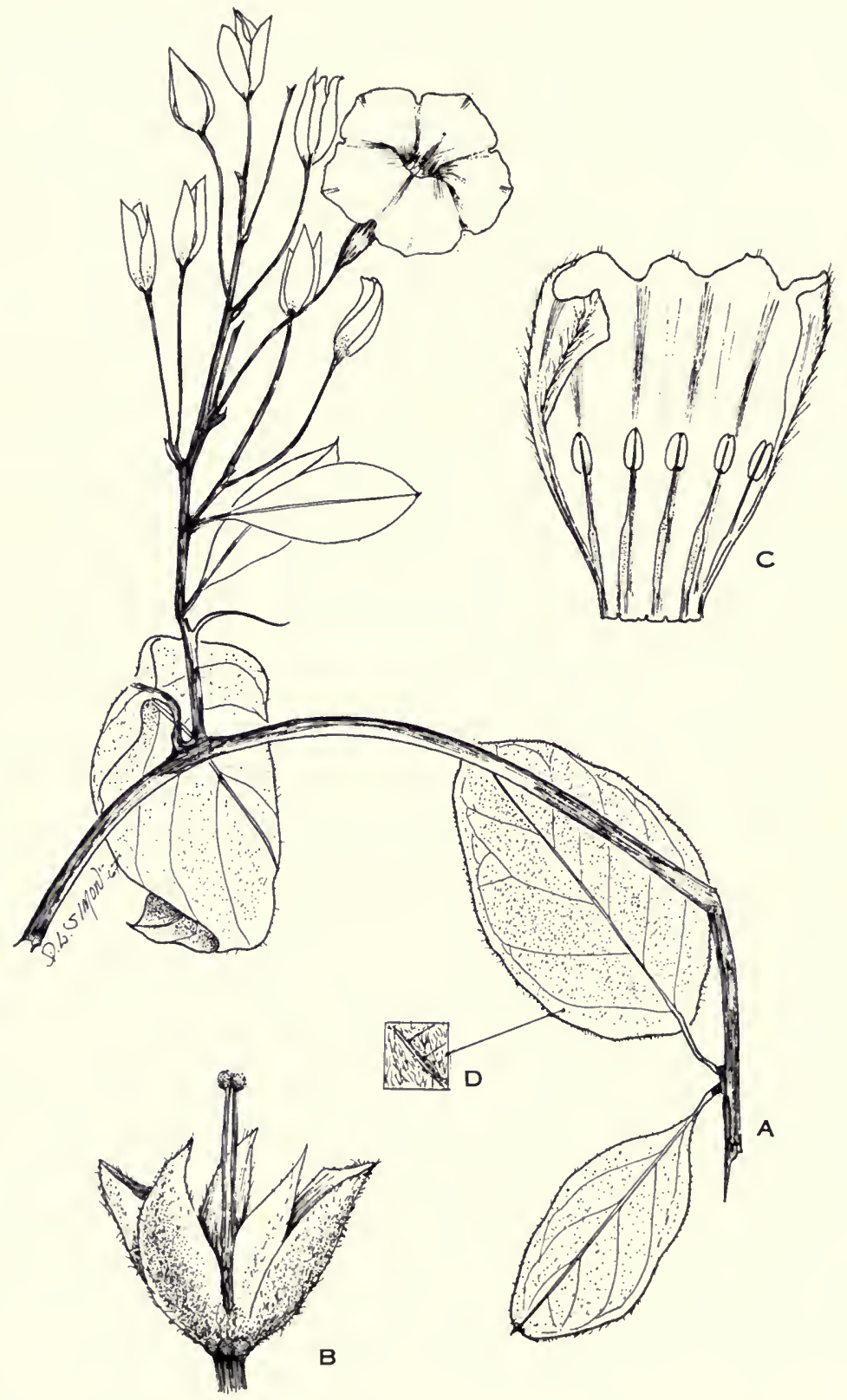

FIg. 1. Bonamia sulphurea. A, habit, natural size; B, calyx (imbricated) with styles, $\times 2$; C, corolla dissected to show stamens, $\times 2$; D, foliar pubescence, much enlarged. 
Rocky, brushy hillsides, 200-900 m.; Zacapa; Chiquimula. Mexico (Veracruz); Honduras.

A woody vine, climbing over shrubs, the stems covered with short, brownish or yellowish, ascending hairs, glabrous in age; leaves short-petiolate, rather thick, entire, elliptic-oblong to oval, $4-7.5 \mathrm{~cm}$. long, rounded and mucronate at the apex, rounded at the base, thinly appressed-pilose above, densely fulvous-pilose or tomentose beneath; flowers numerous, in small cymes, these short-pedunculate or sessile, the pedicels long and slender; sepals $1-1.5 \mathrm{~cm}$. long, lance-oblong or ovateoblong, acute, appressed-pilose; corolla white, $1.5 \mathrm{~cm}$. long, hirsute outside; immature capsule hirsute.

\section{GALONYGTION Choisy}

Large vines, usually herbaceous throughout, the stems sometimes covered with fleshy prickles; leaves large, thin, entire or lobate, cordate at the base; flowers large, white or blue, opening in the evening and closing in the morning; sepals coriaceous or herbaceous, the outer ones of ten with subulate appendages; corolla long-salverform, the tube usually cylindric or nearly so; stamens and style exserted; styles united, the stigmas globose; capsule globose, 2-celled, 4-seeded.

Half a dozen species, widely dispersed in tropical regions. Probably only the following occur in Central America. Hardly distinct from Ipomoea.

Sepals with conspicuous subulate green appendages at the apex; stems with thick aculeate appendages................................ Sepals without subulate appendages.

Stems long hirsute with hollow hairs, flowers blue............. C. clavatum. Stems glabrous or with scale-like pubescence.

Calyx lobes subequal, mostly less than $1 \mathrm{~cm}$. long; stems glabrous; leaves not lobate.............................. ventricosum.

Calyx lobes very unequal, more than $1 \mathrm{~cm}$. long; stems with scale-like pubes-

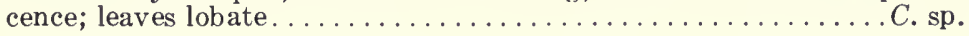

Calonyction aculeatum (L.) House, Bull. Torr. Bot. Club 31: 590. 1904. Convolvulus aculeatus L. Sp. Pl. 155.1753. Ipomoea bonanox L. Sp. Pl. ed. 2. 228. 1762. I. aculeata Kuntze, Rev. Gen. Pl. 2: 442. 1891. Luna blanca (Petén). Moon-flower.

Moist or wet thickets, of ten in second growth, sometimes running over rocky banks, $800 \mathrm{~m}$. or less; Petén; Alta Verapaz; Izabel; Zacapa; Santa Rosa; Escuintla; Sololá; Suchitepéquez; Retalhuleu; San Marcos. Southern Florida; Mexico; British Honduras to El Salvador and Panama; West Indies; South America; Old World tropics.

A small or large herbaceous vine, usually scandent, glabrous, sometimes $20 \mathrm{~m}$. long or more and covering large trees, the sap milky; stems densely armed with short fleshy prickles to smooth; leaves long-petiolate, rounded-ovate, thin, $5-15 \mathrm{~cm}$. 
long, entire or rarely trilobate, abruptly short-acuminate, deeply cordate at the base; peduncles bearing 1-several flowers, usually elongate but shorter than the leaves; sepals green and fleshy, about $1 \mathrm{~cm}$. long, the outer ones (at least) terminated by a long slender green horn-like appendage; corolla tube very slender, 10 $12 \mathrm{~cm}$. long, the limb white, $8-10 \mathrm{~cm}$. broad, each lobe with a broad green median stripe; capsule ovoid, pointed, $2 \mathrm{~cm}$. long; seeds black, glabrous or nearly so.

There is a problem involved in the selection of the proper name for this plant if placed in the genus Ipomoea. It is possible that $I$. tuba (Schlecht.) G. Don is the proper one.

Called "panal de niño" in Honduras; "nata," "naxh" (Chiapas); "nicua," "cración" (Yucatan); "zutub" (Yucatan, Maya); "campanilla blanca," "pitoreta," "bejuco de tabaco," "flor de luna," "galán de noche," "garza" (El Salvador). In the evening, when in full bloom, the plant is a showy and handsome one. It is often grown for ornament in temperate regions where it is not hardy, but must be grown from seeds each summer. When the proper stage of dusk or darkness has arrived, the buds open rapidly, in only a few minutes. The milky sap of this plant and of various other Convolvulaceae has long been used in Central America for coagulating the latex of Castilla rubber trees. The tough stems often are employed in place of string, especially for hanging tobacco leaves to cure (hence the name bejuco de tabaco).

Calonyction clavatum G. Don, Gen. Syst. 4: 264. 1838. Ipomoea clavata v. Oostr. \& Macbride, Field Mus. Bot. 11: 3. 1931. Luna morada.

Moist or dry forest or thickets, $800 \mathrm{~m}$. or less; Petén. Southern Mexico; British Honduras; Nicaragua; Costa Rica; western South America, southward to Ecuador.

A large herbaceous vine, the stems hirsute with very long and soft, hollow, spreading, whitish hairs; leaves long-petiolate, the petioles long-hirsute; leaf blades glabrous or nearly so, rounded ovate, large, acute or acuminate, deeply cordate at the base, entire; peduncles mostly 1-flowered, densely hirsute, much shorter than the petioles, the pedicels stout, glabrous, usually longer than the peduncles, fistulose-thickened above; sepals 2.5-3 cm. long, muticous, glabrous, lance-oblong, obtuse or subacute; corolla blue, about $12 \mathrm{~cm}$. long, the limb $10 \mathrm{~cm}$. broad, the tube dilated upward, $2.5 \mathrm{~cm}$. broad in the throat, glabrous; capsule broadly ovoid, $2.5 \mathrm{~cm}$. long, glabrous; seeds densely covered with long hairs.

Called "morning-glory" and "gloria de la mañana" in British Honduras. The latter name is a Spanish translation of the English one, and probably of recent introduction. The usual Spanish name for plants of this family in most parts of Central America is "cam- 


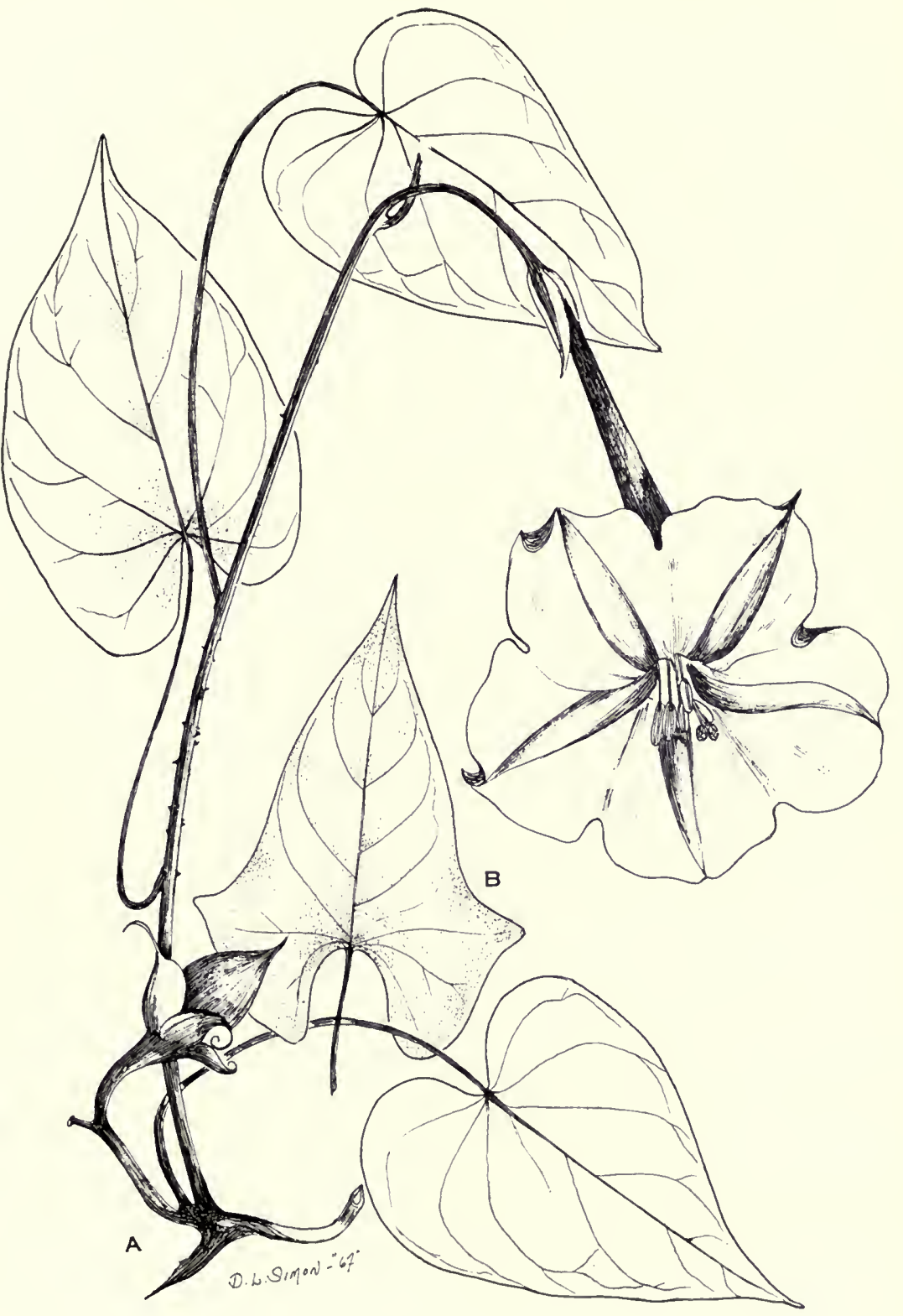

Fig. 2. Calonyction aculeatum. A, habit, $\times \frac{1}{2}$; B, leaf from another collection, natural size. The fruit is also $\times 1 / 2$. Stems are not always aculeate. 
panilla." The vine is an exceptionally beautiful one, one of the most gorgeous of all the morning-glories, its huge blossoms of an exquisite shade of blue rarely seen in flowers.

Calonyction ventricosum Hallier f., Bot. Jahrb. 16: 556. 1893, nomen; Bull. Herb. Boiss. 5: 1027. 1897. Ipomoea santillanii O’Donell, Anal. Inst. Biol. Mex. 12: 93. 1941. Quilamul; campana.

Moist or wet thickets, often in roadside hedges, 200-1,800 m.; Chiquimula; Jutiapa; Santa Rosa; Guatemala; Chimaltenango; Suchitepéquez; Quezaltenango. Southern Mexico; El Salvador; Costa Rica.

A large, coarse herbaceous vine, glabrous throughout or nearly so; leaves longpetiolate, thin, entire, rounded-ovate, usually caudate-acuminate, deeply cordate at the base; peduncles of ten equaling the leaves, divided into 2 long scorpioid branches, several-flowered, the pedicels mostly short, thickened above; bracts whitish or pale green, sometimes tinged with pink, membranaceous, broadly spatulate, large and concealing the flower buds; sepals ovate, glabrous, rounded at the apex, muticous, $1 \mathrm{~cm}$. long; corolla white, the lower part of the tube slender, $3 \mathrm{~cm}$. long, the upper portion dilated, $2.5 \mathrm{~cm}$. long and $2 \mathrm{~cm}$. broad, the limb $6 \mathrm{~cm}$. broad or more.

A showy and rather handsome plant. It is particularly plentiful and conspicuous on the otherwise sterile and uninteresting slopes of Cuesta de la Conora in the Department of Jutiapa.

\section{Calonyction sp.}

Probably edges of clearings or thickets, Alta Verapaz, Steyermark $44999 ; 45121$.

Coarse herbaceous vine; the stems covered with scale-like pubescence to about $3 \mathrm{~mm}$. long, glabrous with age; leaves trilobate, of ten to near the middle, cordate, broadly ovate-suborbicular in outline, to $15 \mathrm{~cm}$. long and nearly as broad, petioles to about $10 \mathrm{~cm}$. long, with sparse scale-like pubescence or none; the calyx lobes in fruit very unequal and large, coriaceous, from about $1.5 \mathrm{~cm}$. long to $4 \mathrm{~cm}$. long; immature capsule to $3 \mathrm{~cm}$. long; seeds pubescent with scale-like hairs.

These specimens have been called $C$. clavatum and $C$. ventricosum, which they are not.

\section{GUSGUTA L. Dodder}

References: T. G. Yuncker, Revision of the North American and West Indian species of Cuscuta, Univ. Ill. Biol. Monog. 6, nos. 2-3: 1-142. 1921; The Genus Cuscuta, Mem. Torr. Bot. Club 19:113-331. 1932; Cuscuta, No. Am. Fl. ser. 2, 4: 1-51. 1965.

Small, twining, parasitic plants without chlorophyll, the stems filiform, yellow or orange (rarely greenish), attached by haustoria to the host plant; leaves reduced 
to minute scales; inflorescence of cymose clusters of small, usually white flowers; calyx gamosepalous and five-parted or rarely the sepals nearly free; corolla usually urceolate or campanulate, the lobes various and usually 5, with scale-like appendages attached at the base within and opposite the stamens to form a corona or sometimes lacking; ovary 2-celled and each cell biovulate; styles distinct (rarely united), terminal, the stigmas capitate to linear; capsule indehiscent or circumcissle near the base.

The genus has perhaps as many as 150 species. The host preference of those of Guatemala is little known and it is assumed that most occur on a variety of hosts. Germination of the seeds is in the sround, the seedling plants soon attach themselves to host plants and the attachment with the soil withers. Certain species cause considerable damage in cultivated crops, especially in flax, beets, and chiles but we do not know of damage to crops by Cuscuta in Guatemala.

Capsule indehiscent; section Clistogrammica.

Capsule globose with a conspicuously thickened stylopodium; flowers rather thick and fleshy, papillate or glandular............... indecora. Capsule depressed-globose, not definitely thickened at the apex.

Calyx lobes acute...................... yucatana. Calyx lobes obtuse.

Corolla lobes obtuse..................... obtusiflora.

Corolla lobes acute..................... campestris. Capsule circumscissile; section Eugrammica.

Styles stout and more or less subulate, tapering to the globose or conic ovary.

Calyx deeply cleft, the lobes distinct or nearly so

C. boldinghii.

Calyx not deeply lobate, definitely gamosepalous.

Calyx lobes much broader than long at maturity; stigmas large and convolute.............................. rugosiceps.

Calyx lobes about as broad as long; stigmas not conspicuously enlarged or convolute...........................

Styles slender, usually of about the same thickness throughout.

Calyx lobes, and usually also the corolla lobes, obtuse.

Flowers about as broad as long. .................. tinctoria.

Flowers longer than broad.

Corolla saccate, subglobose. . ............. corymbosa.

Corolla not saccate, cylindric.............. cozumeliensis.

Calyx lobes, and usually also the corolla lobes, acute.

Pedicels mostly longer than the flowers, in lax inflorescences; lobes of the corolla about equaling the tube............... saccharata.

Pedicels not longer than the flowers, in dense compact inflorescences; lobes of the corolla mostly shorter than the tube...C. costaricensis.

Cuscuta boldinghii Urban, Repert. Sp. Nov. 16: 38. 1919.

Growing on various herbs, $600 \mathrm{~m}$. or less; Santa Rosa; Escuintla; Retalhuleu; Sololá. Southern Mexico; Honduras; Nicaragua; West Indies; Costa Rica. Venezuela. Florida. 
Plants slender; flowers about $2 \mathrm{~mm}$. long, sessile or nearly so, in dense clusters; calyx lobes equaling or longer than the corolla tube, distinct or nearly so, imbricate, oblong or oval, obtuse and mucronate, or obtuse and bearing a horn-like projection from its dorsal surface near the apex; corolla lobes about equaling the campanulate tube, erect or spreading, oblong or oval, obtuse, irregularly dentate at the apex and with a subapical horn-like projection; stamens shorter than the corolla lobes, the anthers small, oval-ovate, shorter than the stout subulate filaments; scales reaching the filaments, oblong or broadly ovate, short-lacerate; styles stout, subulate, much longer than the globose ovary, the stigmas capitate; capsule globose, circumscissile, bearing the withered corolla at its apex; seeds oval, $1 \mathrm{~mm}$. long.

The species is noteworthy for the horn-like projections on the perianth lobes. The plant is called "hierba mala" in Honduras and reported to be poisonous to stock. The genus yields a substance called cuscutin, but there is no clear proof that it has been found poisonous in the United States, although it has been suspected.

Cuscuta campestris Yuncker, Mem. Torr. Bot. Club 18: 138, fig. 1932; No. Am. Fl. ser. II, pt. 4: 5. 1965.

Parasite in clearings near sea level, British Honduras (Gentle 7914). Said by Yuncker to be distributed throughout the range of the genus, but no specimens in our herbarium determined by him. The type locality is Texas. The description is that of Yuncker.

\begin{abstract}
"Stems medium; flowers up to about 1.5-2 mm. long from the base of the flower to the corolla sinuses, appearing much larger when in fruit, smooth or with scattered, pellucid, gland-like cells, on pedicels mostly shorter than the flowers, in glomerulate-cymose clusters; calyx about as long as the corolla tube, the lobes overlapping at the base, but not markedly angled at the sinuses, ovate to ovalovate, commonly as long as wide, obtuse; corolla tube campanulate, soon enlarging about the maturing capsule, the lobes triangular to sublanceolate, about as long as the tube, spreading to reflexed, of ten granulate, the tips acute, inflexed; stamens shorter than the lobes; filaments slightly subulate, as long as or somewhat longer than the oval anthers; infrastamineal scales reaching the filaments, ovateoblong, abundantly fringed with medium-length processes, bridged below the middle; style slender to slightly subulate, as long as or longer than the globose ovary; stigmas capitate; capsule depressed-globose, the withered corolla remaining about the lower half; seeds ovate in outline, about $1.5 \mathrm{~mm}$. long; hilum short, oblong; embryo slender, with about 2 coils."

We have followed Prof. Yuncker in using the name C. campestris for this plant, although we think it possible that the proper one may be $C$. arvensis Beyrich.
\end{abstract}

Cuscuta corymbosa R. \& P. var. grandiflora Engelmann, Trans. Acad. St. Louis 1: 483. 1859. Tripa de gallina; cabello de león; pelo de león; bejuco de mesquino; pelo de angel; cancam (Quecchí); fideos; cabellos de angel; barba de león. 


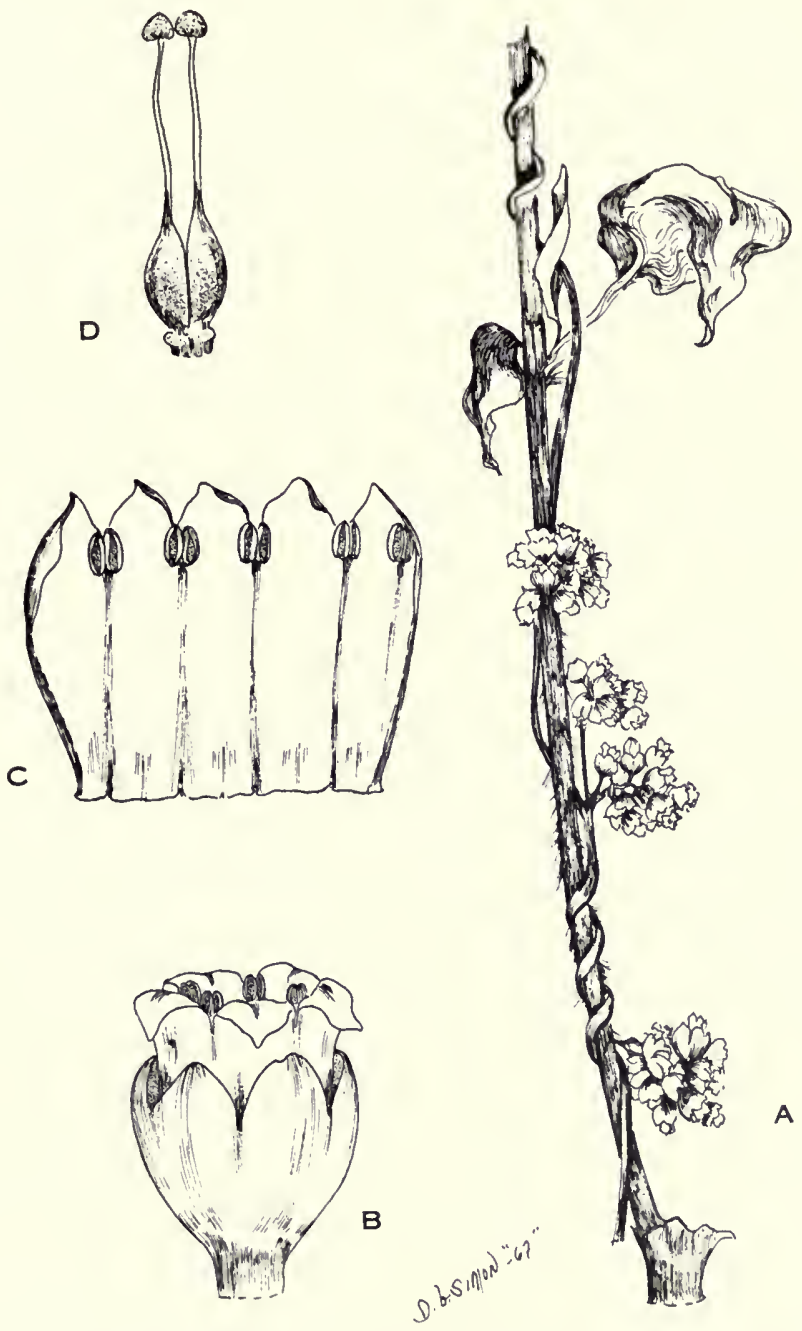

FIG. 3. Cuscuta corymbosa var. grandiflora. A, habit of the parasite, natural size; $\mathrm{B}$, flower, $\times 5$; C, corolla dissected to show stamens in natural position, $\times 5$; D, pistil, $\times 5$.

Parasitic on shrubs or coarse herbs, 2,700 m. or lower; Alta Verapaz; El Progreso; Jalapa; Escuintla; Guatemala; Sacatepequez; Chimaltenango; Sololá; Suchitepéquez; Retalhuleu; Quezaltenango. Southern Mexico; El Salvador to Costa Rica; northwestern South America.

Stems bright orange (as in other species), the corolla white; flowers $4-8 \mathrm{~mm}$. long, on pedicels of about equal length, in rather lax, corymbose-paniculate inflores- 
cences; calyx about reaching the middle of the corolla tube, the lobes short, broad, obtuse, slightly imbricate; corolla lobes one-fourth to one-half as long as the tube, ovate-oblong, obtuse, erect or spreading; scales thin, narrow, reaching the middle of the tube, dentate or with a few scattered processes; capsule globose, circumscissile, capped and surrounded by the withered corolla; seeds 1-1.5 mm. long.

The Maya name "canlecay" has been reported from Yucatan for this or a related species. The vernacular names cited above are, of course, applied indiscriminately to all species, and all are alike in general appearance and color. In some parts of Guatemala, especially in the Pacific coastal plain, the plants often are seen in great abundance, densely covering shrubs and tall herbs. The plants are often used in Guatemala for dying textiles. Dieseldorff states that about Cobán the plants are employed in domestic medicine to treat eruptions on the face. This variety has been reported from Guatemala as C. americana L.

Cuscuta costaricensis Yuncker, Mem. Torr. Club 18:227. 1932. Bejuco de mesquino. Central Mexico; Costa Rica.

Stems slender; flowers $3-4 \mathrm{~mm}$. long, more or less papillate, subsessile, in dense glomerulate clusters; calyx loose about the corolla tube, the lobes broadly ovate, acute or acuminate, slightly imbricate; corolla lobes broadly ovate or suborbiculate, erect or spreading, shorter than the campanulate tube, acute or acuminate or usually cuspidate; stamens shorter than the corolla lobes, the filaments equaling or exceeding the oval anthers; scales oblong, reaching the stamens, fimbriate; styles slender, much longer than the globose ovary; capsule depressed-globose, circumscissile; seeds $1.7 \mathrm{~mm}$. long, ovoid.

Cuscu ta cozumeliensis Yuncker, Bull. Torr. Bot. Club 49: 108, f. 2. 1922.

Parasitic on shrubs, $600 \mathrm{~m}$. or less; Suchitepéquez; Retalhuleu. Mexico, Yucatan, the type from Cozumel Island.

Stems rather coarse; flowers 2-3 mm. long, the pedicels equaling or shorter than the flowers, in cymose clusters; calyx shorter than the corolla tube, the lobes ovate-orbiculate, imbricate, somewhat carnose toward the base; corolla lobes erect or spreading, imbricate, obtuse or rarely subacute, half as long as the cylindric tube; stamens shorter than the corolla lobes, the filaments equaling or slightly longer than the oval anthers; scales reaching the stamens or shorter, oblong, moderately laciniate; styles slender, much longer than the depressed-globose ovary; capsule circumscissile.

Cuscuta indecora Choisy, Mem. Soc. Phys. Hist. Nat. Geneve 9: $278, t$. 3, f. 3. 1841.

On low herbs, near sea level; British Honduras (Malfredi Lagoon, Schipp 1161). Mexico. 
Flowers 2-3 mm. long, fleshy, papillose-hispid, the pedicels longer than the flowers; calyx lobes triangular-ovate, acute or obtuse, shorter than the corolla tube; corolla campanulate, the lobes erect or spreading, triangular, acute, with inflexed tips; scales equaling or longer than the corolla tube, ovate or subspatulate, deeply fimbriate; stamens shorter than the corolla lobes, the anthers broad, oval, about equaling the filaments; styles equaling or slightly longer than the globose pointed ovary, divaricate in fruit; capsule globose, thickened at the apex, surrounded by the withered corolla; seeds $1.7 \mathrm{~mm}$. long, roundish or broader than long, somewhat scurfy.

Cuscuta jalapensis Schlecht. Linnaea 8: 515. 1833. Fideos; cabellos de angel; barba de león; coralillo; flor de cadena.

On shrubs and coarse herbs, 1,300-3,000 m.; Jalapa; Chimaltenango; Huehuetenango; Totonicapán; Quezaltenango; San Marcos. Southern Mexico.

Stems of medium thickness, orange; flowers $2.5-5 \mathrm{~mm}$. long, white or greenish white, the pedicels equaling or shorter than the flowers, densely clustered; calyx usually shorter than the campanulate corolla, the lobes imbricate, ovate, obtuse, somewhat thickened and verrucose along the middle; corolla lobes ovate, obtuse, shorter than the tube, erect or reflexed; scales ovate-oblong, about equaling the tube or exserted, fimbriate; stamens shorter than the corolla lobes, the anthers ovate, about equaling the filaments; styles strongly subulate, mostly shorter than the globose-conic ovary; capsule globose, circumscissile, surrounded by the withered corolla, the styles conic, widely divergent; seeds $1.5 \mathrm{~mm}$. long, ovoid.

This species seems to be confined in Guatemala to the higher mountains, and often is found as high as the Cupressus forests. Near Palojuno (Quezaltenango) the senior author's attention was attracted one day by what he assumed to be great masses of shrubs with orange flowers about a mile away. Walking across the fields to see what this unknown and remarkably showy plant might be, he was disgusted when he reached the spot to find that these solid masses of color consisted of Cuscuta plants covering Sambucus bushes.

Cuscuta obtusiflora HBK. var. glandulosa Engelm. Trans. Acad. St. Louis 1: 492. 1859.

On low shrubs, $600 \mathrm{~m}$. or less; Jutiapa (Steyermark 31988). United States; Mexico; Costa Rica; West Indies.

Stems of medium thickness; flowers $2 \mathrm{~mm}$. long, glandular, subsessile, in compact glomerulate clusters; calyx enclosing the corolla tube, the lobes unequal, rounded-ovate, obtuse, the margins usually irregularly serrulate, not imbricate; corolla lobes triangular-ovate, acute or subobtuse, spreading or reflexed, shorter than the campanulate tube; stamens shorter than the corolla lobes, the filaments equaling or longer than the oval or cordate anthers; scales oblong, fimbriate at the apex, scarcely reaching the stamens; styles rather stout and subulate, shorter than 
the globose ovary or about equaling it; capsule depressed globose, indehiscent, the styles subulate and divergent; seeds ovate, $1.5 \mathrm{~mm}$. long.

Cuscuta rugosiceps Yuncker, Univ. Ill. Biol. Mongr. 6, nos. 2-3: 117. f. 1, 70, 155. 1921.

On shrubs or coarse herbs, $1,600-3,300 \mathrm{~m}$.; Sacatepéquez; Quiché; San Marcos; Huehuetenango. Southern Mexico.

Stems coarse; flowers glabrous, 4-6 mm. long, sessile, in compact clusters; calyx large, campanulate, almost as long as the corolla tube, the lobes short, usually broader than long, unequal, obtuse, imbricate, sometimes carinate; corolla lobes ovate, obtuse, spreading, shorter than the campanulate tube; scales reaching the filaments, fimbriate; stamens shorter than the corolla lobes, the anthers oval, about equaling the filaments; ovary small, somewhat conic, tapering into the subulate styles, the stigmas large and more or less convolute; capsule circumscissile, with a very thick apex, giving the capsule a conic appearance, surrounded by the withered corolla; seeds rounded, compressed, $1.4 \mathrm{~mm}$. long.

Cuscuta saccharata (Engelm.) Yuncker, Mem. Torrey Club 18: 239. 1932. C. gracillima var. saccharata Engelm. Trans. Acad. Sci. St. Louis 1: 489. 1859.

Parasitic on herbs, 200-550 m.; Zacapa; Chiquimula. Southern Mexico; Honduras; Costa Rica.

Stems very slender; flowers $2-2.5 \mathrm{~mm}$. long, densely papillate (as also the stems, pedicels and bracts), the slender pedicels longer than the flowers, in dense compact clusters; calyx about equaling the corolla tube, the lobes ovate-lanceolate, acute or acuminate; corolla lobes erect or spreading, about equaling the campanulate tube; stamens shorter than the corolla lobes, the slender filaments longer than the oval anthers; scales ovate, reaching the stamens, short-fimbriate; styles slender, longer than the globose ovary; capsule globose, thin, irregularly circumscissile; seeds oval, $1 \mathrm{~mm}$. long.

Cuscuta tinctoria Mart. ex Engelm. Trans. Acad. Sci. St. Louis 1: 480.1859.

On shrubs or trees; Sacatepéquez; Quiché; Totonicapán (Lehmann 1682). Mexico.

Flowers smooth, 4-5 mm. long, sessile or short-pedicellate, single or in dense glomerules of many flowers; calyx lobes unequal, orbicular, obtuse, imbricate, about equaling the corolla, sometimes carinate; corolla campanulate, becoming urceolate in fruit, thinner toward the base, the lobes ovate or almost oblong, obtuse, imbricate, erect or usually spreading; scales reaching the filaments; stamens shorter than the corolla lobes, the filaments about equaling the oval-oblong anthers; styles usually longer than the globose ovary, exserted in fruit; capsule depressedglobose, circumscissile; seeds $1.5 \mathrm{~mm}$. long, angulate. 
Cuscuta tinctoria var. kellermaniana Yuncker, Univ. Ill. Biol. Monogr. 6, nos. 2-3: 32, f. 16. 1921.

Known only from the type, Volcán de Agua, Sacatepéquez, 2,700 m., W. A. Kellerman 7567; on Ceanothus.

Like the species, but the scales oblong, sparsely fimbriate; styles shorter than the depressed-globose ovary and capsule, not exserted.

Cuscuta yucatana Yuncker, Bull. Torr. Bot. Club 62: 511. 1935. Coralillo.

On Houstonia serpyllacea, 2,500 m.; Jalapa (Montaña Miramundo, Steyermark 32648). Known otherwise only from Valladolid, Yucatan.

Stems slender; flowers $2 \mathrm{~mm}$. long, the pedicels equaling or longer than the flowers, in compound umbellate cymes; calyx longer than the corolla tube, the lobes triangular-ovate, acute, not imbricate; corolla lobes oblong-lanceolate, very harply acute, erect in young flowers, the tips inflexed, soon becoming reflexed, the lobes equaling or longer than the campanulate tube, more or less grandular-papilate; filaments slender or slightly subulate, mostly 2-3 times as long as the ovalelliptic anthers; scales oblong or subspatulate, reaching the stamens, fimbriate; tyles equaling or longer than the depressed-globose ovary; capsule depressedglobose, not circumscissile; seeds $0.8-1 \mathrm{~mm}$. long, oval.

The distribution of this species is remarkable, for it would be hard to imagine two regions more unlike than the localities from which the plant is known at present. Even though both specimens known, the type and Steyermark 32648, have been determined by Prof. Yuncker we are inclined to suspect that the Guatemalan collection represents another species.

\section{DICHONDRA Forster}

Reference: B. C. Tharp \& Marshall C. Johnston, Recharacterizaion of Dichondra and a revision of North American species, Brittonia 13: 346-360. 1961.

Slender perennial herbs, glabrous or sericeous; leaves small, cordate-orbicular or reniform, entire, long-petiolate; flowers minute, solitary and pedicellate in the eaf axils; sepals subequal, distinct, usually spatulate; corolla broadly campanuate, deeply 5-fid, the lobes induplicate; stamens shorter than the corolla, the ilaments filiform, the anthers small; ovary bilobate, the lobes distinct, 2-celled, oiovulate; styles 2 , between the lobes, filiform, the stigmas capitate; capsules 2 , nembranaceous, erect, usually 1 -seeded, indehiscent or irregularly bivalvate; seeds ubglobose, smooth; cotyledons oblong-linear, 2-plicate.

Perhaps a dozen species, widely distributed in tropical and warmemperate regions. Only the following is known from Central America. 
Dichondra sericea Sw. Prodr. Veg. Ind. Occ. 54.1788. D. repens var. sericea Choisy in DC. Prodr. 9: 451. 1845.

Usually in moist or dry open, often rocky slopes in open forest, sometimes in moist shaded habitats, $1,200-2,500$ m. Alta Verapaz; Chiquimula; Jalapa; Jutiapa; Escuintla; Guatemala; Sacatepéquez; Chimaltenango; Sololá; Huehuetenango; Quezaltenango; San Marcos. Arizona; Mexico; Central America; the West Indies and South America.

Plants very slender, repent, rooting at the nodes, the stems usually short but sometimes $30 \mathrm{~cm}$. long or more, appressed-pilosulous or glabrate; leaves long-petiolate, reniform or cordate-orbicular, mostly $8-20 \mathrm{~mm}$. broad, broadly rounded at the apex and often emarginate, deeply cordate at the base, green on both surfaces, sparsely pilosulous on both surfaces with subappressed hairs to sericeous below; peduncles shorter than the petioles, filiform; sepals oblong or spatulate-oblong, obtuse, green, pubescent, about equaling the corolla, shorter than the capsule, about $2 \mathrm{~mm}$. long; corolla yellowish; capsules densely pilose.

We have followed the work of Tharp and Johnston, cited above, with some reservations. Their work is based on relatively little of the material now available and limited in extent-consequently open to some question.

\section{EVOLVULUS L.}

Reference: Simon Jan van Ooststroom, A monograph of the genus Evolvulus, in Med. Bot. Mus. \& Herb. R. Univ. Utrecht 14: 1-267. 1934 .

Plants usually slender, annual or perennial, herbaceous or suffrutescent, not twining, sometimes creeping; leaves small, of ten narrow, entire; flowers in axillary, peduculate, 1-several-flowered dichasia, sometimes solitary, pedunculate or sessile in the leaf axils; sepals 5, free, equal or subequal; corolla small, rotate, funnelform, or salverform, blue or white, the limb plicate, usually subentire, the lobes with a pilose longitudinal stripe outside; stamens 5 , the filaments filiform, inserted at the mouth of the corolla tube; anthers ovate to oblong or linear; ovary 2-celled, each cell 2-ovulate, sometimes 1-celled and 4-ovulate; styles 2, slightly united at the base or wholly free, each style 2-cleft; stigmas long, terete, filiform or subclavate; capsule globose or ovoid, 4-valvate, 4-1-seeded; seeds small, smooth or minutely verrucose; cotyledons almost flat, the radicle incurved.

About 100 species, widely distributed in both hemispheres, mostly in the warmer regions.

Inflorescence not pedunculate, the flowers solitary or fasciculate from leaf axils.

Plants repent, the stems rooting at the nodes; leaves broadly oval or orbicular.

Plants erect or ascending; leaves oblong-ovate to linear.

E. nummularius.

Leaves oblong-ovate; stems pilose with long, lax, spreading hairs...E. ovatus. 
Leaves linear to oblong; stems strigose or sericeous E. sericeus. Inflorescence pedunculate, axillary or sometimes terminal.

Pubescence of the stem spreading, leaves variable.

Corolla $3-7 \mathrm{~mm}$. broad . . . . . . . . . . . . . . . E. alsinoides. ${ }^{1}$

Corolla $10 \mathrm{~mm}$. broad, the leaves $12-20 \mathrm{~mm}$. broad . E. tenuis. ${ }^{1}$ Pubescence of stem appressed E. filipes. ${ }^{1}$

Evolvulus alsinoides L. Sp. Pl. ed. 2. 392. 1762. Convolvulus alsinoides L. Sp. Pl. 157. 1753. C. linifolius L. Amoen. Acad. 4: 306. 1759. Quiebra-cajete; cenicito.

Usually in open, moist or dry places, sometimes in thickets or on rocky banks, often in pine forest, frequently a weed in cultivated ground, 200-1,900 m.; Baja Verapaz; Alta Verapaz; Izabal; Jalapa; Jutiapa; Santa Rosa; Escuintla; Guatemala; Sacatepéquez; Chimaltenango; Sololá; Suchitepéquez; Huehuetenango. Southwestern United States; Mexico; British Honduras to El Salvador and Panama; widely distributed in temperate and tropical America and in the Old World.

Plants slender, annual or perhaps sometimes perennial, erect to prostrate, often much branched, pilose with appressed or spreading hairs; leaves mostly oblong to elliptic-oblong or lanceolate and 1-2.5 $\mathrm{cm}$. long, usually $1 \mathrm{~cm}$. broad or less, on very short petioles, obtuse or acute, rounded or acute at the base, generally rather densely appressed-pilose, especially beneath; inflorescence axillary, shorter than the leaves or of ten much longer, 1-few-flowered, peduncles almost filiform; pedicels equaling or longer than the calyx; sepals lanceolate, acute or acuminate, $1.5-3 \mathrm{~mm}$. long, pilose; corolla pale blue or sometimes white, $3-5.5(-7) \mathrm{mm}$. broad; ovary glabrous; capsule globose, with 4 or fewer seeds, these black, smooth.

Called "oreja de ratón" in El Salvador; "xiatiu" (Yucatan, Maya).

S. J. Ooststroom indicates that there are four varieties of this species in Guatemala: var. griesbachianus Meissn., var. debilis (HBK.) v. Ooststr., var. adscendens (House) v. Ooststr., and var. acapulcensis (Willd.) v. Ooststr. The differences seem slight if not non-existent. Van Ooststroom recognized 15 varieties of this species, world-wide.

Evolvulus filipes Mart. Flora 24, Beibl. 2: 100. 1844.

Moist shaded places, or sometimes a weed in cultivated fields, 200-2,000 m.; Zacapa; Jalapa; Jutiapa; Santa Rosa; Guatemala; Huehuetenango. Mexico; Honduras to Panama; Jamaica; South America.

${ }_{1}$ The junior author is not at all sure that the Central American material traditionally named as $E$. alsinoides and $E$. filipes represents other than a single weedy and somewhat variable species. Evolvulus tenuis likewise seems doubtfully distinct from $E$. alsinoides, as represented by Central American material. 
Plants annual, erect or ascending, usually $30 \mathrm{~cm}$. high or less, of ten densely branched, the stems sparsely appressed-pilose; leaves sessile or on very short petioles, linear or narrowly lanceolate, $1-2.5 \mathrm{~cm}$. long, mostly $2-5 \mathrm{~mm}$. broad, acute or subobtuse, acute at the base, very sparsely pilose or glabrous above, sparsely appressed-pilose beneath; peduncles longer or shorter than the leaves, mostly 1-2flowered, the pedicels equaling or shorter than the calyx, reflexed in fruit; sepals lanceolate, glabrous or sparsely pubescent, ciliate, $2-2.5 \mathrm{~mm}$. long; corolla pale blue or white, at most twice as long as the sepals, $3-4.5 \mathrm{~mm}$. broad; ovary glabrous; capsule little exceeding the sepals, globose or ovoid, with 4 or fewer seeds, these brownish black, smooth.

The Maya name of Yucatan is recorded as "yax-cumil."

Traditionally $E$. filipes has been considered to be distinct from $E$. alsinoides, having smaller flowers, narrower more glabrous leaves, pubescence of the stems appressed. The junior author finds that these characters are not consistent and believes that so far as the Central American material is concerned only one somewhat variable and weedy species is involved. Until monographic work can be done it would be as well to name all pedunculate Evolvulus in Central America as E. alsinoides.

Evolvulus nummularius L. Sp. Pl. ed. 2. 391. 1762. Convolvulus nummularius L. Sp. Pl. 157. 1753. Volvulopsis nummularium Roberty, Candollea 14: 28. 1952. Hierba de pesar (Petén, fide Lundell); cuartillo.

Moist shaded places, often among cobblestones in streets, frequent on roadside banks or a weed in cultivated fields, $1,200 \mathrm{~m}$. or less; Petén; Izabal; Zacapa; Chiquimula; Jutiapa; Santa Rosa; Escuintla; Guatemala; Suchitepéquez; Retalhuleu. Mexico; British Honduras to El Salvador and Panama; West Indies; South America; Old World tropies.

Plants perennial, herbaceous, repent, rooting at the nodes, the stems short or often $50 \mathrm{~cm}$. long, pilose with short spreading curved hairs; leaves distichous, short-petiolate, broadly oval to orbicular, $4-15 \mathrm{~mm}$. long, rounded or emarginate at the apex, rounded or subcordate at the base, glabrous or of ten sparsely appressedpilose beneath; flowers 1-2 in each leaf axil, the pedicels 2-6 $\mathrm{mm}$. long, recurved in fruit; sepals 2.5-4 mm. long, ovate-oblong, obtuse or subacute, sparsely pilose or glabrous, ciliate; corolla white, 5-7 mm. broad; ovary glabrous; capsule globose, equaling or slightly longer than the sepals, with 4 or fewer seeds.

Evolvulus ovatus Fernald, Proc. Amer. Acad. 33: 89. 1898.

Dry brushy plains or hillsides, 200 m.; Zacapa. Western Mexico; Colombia and Venezuela to Brazil. 


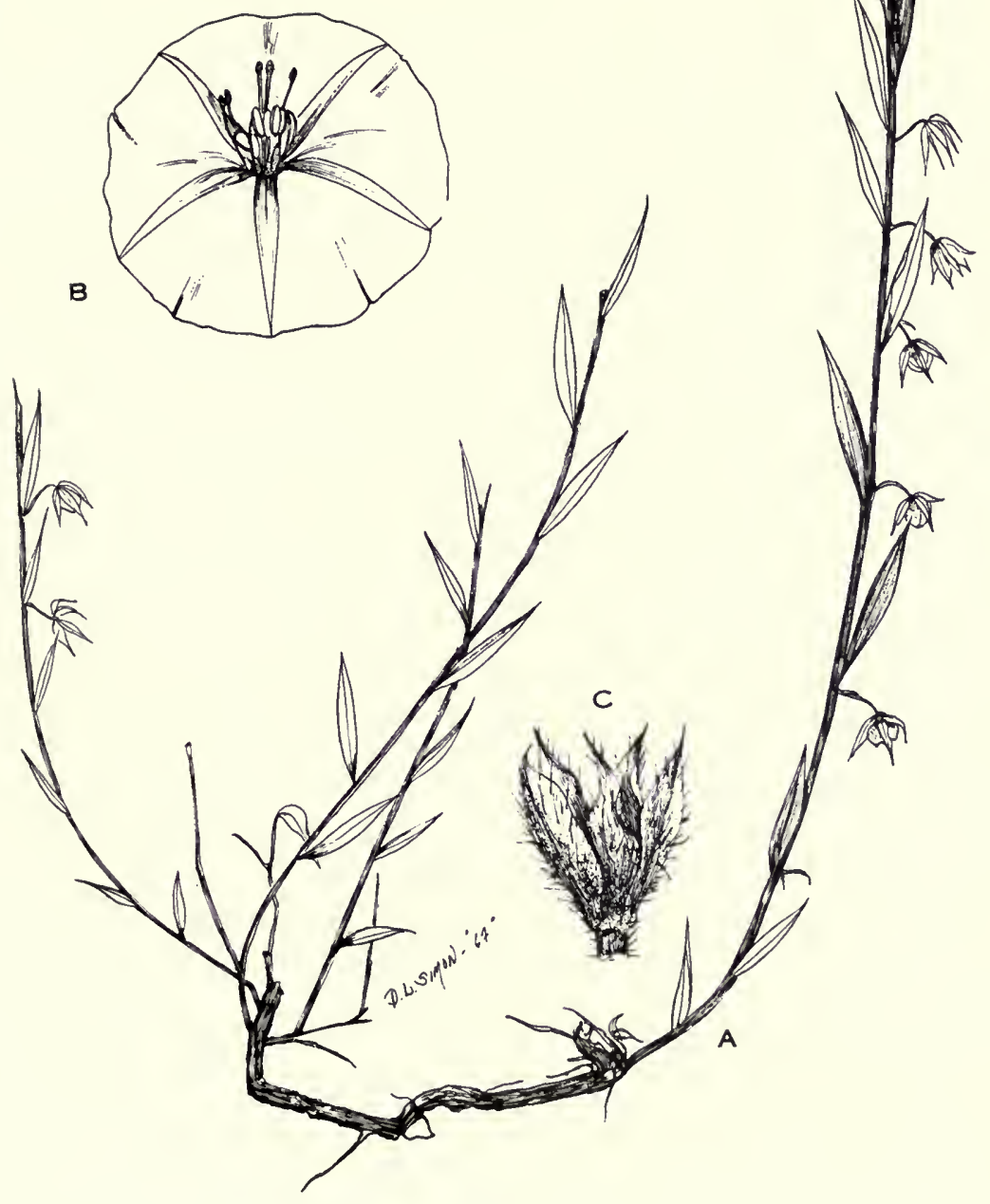

FIG. 4. Evolvulus sericeus. A, habit of plant, natural size; B, flower with corolla in natural position, $\times 3 ; \mathrm{C}$, calyx, $\times 4$. 
Plants annual, erect, $30 \mathrm{~cm}$. high or less, sparsely branched, the stems villous with long spreading lax hairs; leaves short-petiolate or the upper ones sessile, oblong-ovate, 1-3 cm. long, obtuse or subacute, rounded or subcordate at the base, sparsely appressed-pilose on both sides with very long, lax hairs; inflorescence axillary, flowers 1-2, the pedicels shorter than the calyx, reflexed in fruit; sepals lanceolate, acute, $4-5 \mathrm{~mm}$. long, pilose; corolla blue, $5 \mathrm{~mm}$. broad; ovary glabrous; capsule depressed-globose, shorter than the sepals, 4-seeded; seeds smooth, dark brown.

Evolvulus sericeus Swartz, Prod. Veg. Ind. Occ. 55. 1788.

Savannas or open grassy places, sometimes on rocky slopes, on serpentine outcrops, or in pine forest, 2,000 m. or less; Petén; Alta Verapaz; Zacapa; Chiquimula; Santa Rosa; Huehuetenango. Southwestern United States; Mexico; British Honduras to El Salvador and Panama; West Indies; South America.

Plants perennial, erect or ascending, mostly $25 \mathrm{~cm}$. high or less, of ten densely branched from the base, sometimes suff rutescent below, the stems slender but stifi, grayish-sericeous; leaves erect or erect-spreading, sessile or nearly so, linear or linear-lanceolate or elliptic, sericeous, at least beneath, sometimes glabrous on the upper surface, 1-2.5 cm. long, 1-8 mm. broad; flowers solitary or few in the leaf axils, sessile or short-pedicellate, reflexed in age; sepals narrowly oblong-lanceolate, acuminate, 3-5 mm. long, densely appressed-pilose; corolla white or pale blue, 7-12 mm. broad; ovary glabrous; capsule globose, 1-4-seeded; seeds brown, smooth.

The common form of the species in Guatemala has leaves pubescent on both surfaces. Two collections are referable to the following variety:

Evolvulus sericeus var. discolor (Benth.) Gray, Syn. Fl. 2, pt. 1: Suppl. 436. 1886. E. discolor Benth. Pl. Hartw. 6. 1839.

Grassy open slopes, 2,200 m.; Huehuetenango. Southwestern United States; Mexico.

Differing from the common form (in Guatemala) of the species in having broader leaves which are glabrous rather than pubescent on the upper surface.

Evolvulus tenuis Mart. ex Choisy, Mem. Soc. Phys. Hist. Nat. Geneve 78. 1837.

Dry or moist, brushy slopes, 1,400 m. or less; Chiquimula; Quezaltenango(?). Yucatan; Costa Rica; South America.

Plants erect or ascending, annual or somewhat suffrutescent at the base, the stems sometimes more than a meter long, rather sparsely branched, the stems densely pilose with long pale ascending hairs; leaves mostly ovate or oblong-ovate and 1.5-3.5 cm. long, 1-2 cm. broad, acute or acuminate, sparsely or of ten densely 
appressed-pilose; peduncles longer or shorter than the leaves, 1-few-flowered, the pedicels usually longer than the calyx; sepal lanceolate, acute or acuminate, 2.5$3 \mathrm{~mm}$. long; corolla blue or white, $10 \mathrm{~mm}$. broad, ovary globose, glabrous.

This is presumably the plant reported by Hemsley from Llano de San Juan de Dios, Quezaltenango, as E. villosus Ruiz \& Pavón, Bernoulli 181. The species is very closely related to $E$. alsinoides L.

\section{IPOMOEA L.}

References: Homer Doliver House, The North American Species of the genus Ipomoea, Ann. N. Y. Acad. Sci. 18: 181-263. 1908. Eizi Matuda, El Género Ipomoea en México, An. Inst. Biol. 24: 85-145. 1964, 25: 45-76. 1965, 26:83-106. 1965.

Twining or creeping, rarely erect herbs or shrubs, rarely trees. Leaves alternate, entire, angled, lobate, or palmately or pinnately divided, usually petiolate; the flowers usually large and showy, usually fugacious; the inflorescences usually axillary, rarely aggregated in terminal panicles; sepals coriaceous or foliaceous, equal or unequal, persistent; corolla funnelform or campanulate, rarely salverform, the limb entire or 5-angulate, rarely 5-lobate, usually induplicate; stamens included, rarely exserted; pollen said to be spinulose; ovary 2-4-celled; style included, the stigmas 1-2, globose-capitate; capsule 2-4-valvate, 2-4-seeded; seeds often densely lanate or pubescent.

The genera Quamoclit, Turbina, Exogonium, and Calonyction are sometimes included in Ipomoea but are kept separated in this florahowever, in each case names in I pomoea are provided in the synonomy.

There are perhaps not fewer than 400 species of Ipomoea which are widely distributed, the majority of them in tropical regions. There are currently credited to Mexico, Central America, and Panama, in our index to this region, about 250 species (and a few varieties). There are to be expected from Guatemala additional species as collections continue, for this genus is difficult to collect and has been neglected.

Two accounts of Ipomoea are useful in the study of the Guatemalan species, both mentioned above. Mr. House's treatment was prepared more than 60 years ago when Central America was relatively little known. Professor Matuda's account of the Mexican species is helpful for those of Guatemala.

Species of Ipomoea seem to be widely ranging and there is little doubt that when the South American species have been compared more critically with those of North America some changes will be required in the nomenclature used here. Many Ipomoeas occur at relatively low elevations and experience indicates that it is from these regions that most wide-ranging plants are found. 
The Ipomoeas produce some of the showiest and most beautiful flowers of Guatemala, and occur in great abundance almost anywhere at low and at middle elevations, more abundantly in the foothills and on the plains. In some places along the foothills or lowlands of Escuintla and Santa Rosa one rides for miles in the morning with solid sheets of morning-glory flowers on each side of the road. The flowers of all or most species open in the evening and close usually before noon. In the higher parts of central and western Guatemala there are few Ipomoeas, or only an occasional plant may be found. The flowers are much visited by bees. The people of Chiquimulilla (Santa Rosa) claim that the superior flavor of honey produced there is due to the fact that it comes largely from Ipomoea flowers. The most common vernacular name current in Guatemala for this genus is "campanilla," but other terms, such as "quilamul," sometimes are used, and even "alegría de la mañana," which is probably a translation of the usual English name.

\section{KEY TO IPOMOEA}

Plants not twining, erect or climbing shrubs or trees, or sometimes almost wholly herbaceous.

Leaf blades obtuse or rounded at the base; trees; corolla white; seeds with white hairs on the dorsal angles only.

Sepals and corolla glabrous................... pauciflora.

Sepals and corolla pubescent.

Corolla and sepals tomentose outside; sepals $2-3 \mathrm{~cm}$. long . . . I. murucoides.

Corolla and sepals puberulent; sepals $1 \mathrm{~cm}$. long or shorter. . .I. arborescens.

Leaf blades cordate or subcordate at the base; corolla white or purple-pink; seeds with black hairs on all surfaces................. fistulosa.

Plants twining or repent, usually herbaceous throughout or nearly so.

Sepals herbaceous, at least above, sometimes subcoriaceous but then covered with long, fleshy, subulate tubercles, of ten elongated and densely pilose; ovary usually 3 -celled.

Sepals covered with long spreading setae or fleshy tentacular outgrowths.

Leaves deeply lobate, the lobes 3-7.

Sepals oblong, obtuse, $10-14 \mathrm{~mm}$. long. .............. setosa.

Sepals linear-lanceolate, about $25 \mathrm{~mm}$. long............. silvicola. Leaves entire.

Sepals all long-attenuate. ................... silvicola.

Sepals, at least the inner ones, very obtuse........... crinicalyx.

Sepals merely pilose or hirsute, or glabrate, never with fleshy outgrowths.

Corolla copiously pubescent outside; leaves densely sericeous beneath.

Corolla glabrous; leaves rarely if ever sericeous.

I. mairetii.

Sepals glabrous or with only short appressed hairs

I. indica.

Sepals hirsute, at least below, with long spreading hairs.

Corolla small, only $2-3 \mathrm{~cm}$. long; inflorescences dense and head-like, much shorter than the leaves................ meyeri. 
Corolla large, 4-8 cm. long; inflorescences usually open, often longpedunculate.

Sepals abruptly contracted into a long linear tip, $2-3 \mathrm{~cm}$. long; leaves trilobate............................. nil.

Sepals acute or gradually acuminate, usually shorter.

Inflorescences short-pedunculate; stems usually glabrous; sepals acuminate. . . . . . . . . . . . ..... indica var. variabilis.

Inflorescences long-pedunculate; stems usually hirsute; sepals merely acute or sometimes obtuse.

Stems creeping, rooting at the nodes, densely long-hirsute; sepals lance-linear. . ................... ophioides.

Stems scandent, not rooting at the nodes, short-hirsute; sepals broader.

Inner sepals mostly $12-15 \mathrm{~mm}$. long, obtuse; leaves entire; corolla $6-8 \mathrm{~cm}$. long............... tyrianthina.

Inner sepals mostly 9-12 mm. long, acute; leaves trilobate or entire; corolla $4-6 \mathrm{~cm}$. long............. purpurea.

Sepals coriaceous, membranaceous, or obscurely herbaceous, usually not elongate, most of ten glabrous but sometimes pubescent; ovary usually 2- or 4celled.

Leaves deeply palmate-lobate or pinnate-lobate almost to the base or to the costa, the lobes narrow; plants erect or usually twining.

Leaves sessile, divided to the base into fliform segments; plants usually

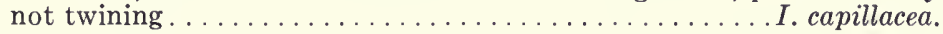

Leaves petiolate, the segments linear or often much broader; plants usually twining.

Lobes of the leaves less than $4 \mathrm{~cm}$. long; small vines.

Sepals cuspidate; peduncle not coiled.............. costellata.

Sepals rounded at the apex; peduncles usually spirally coiled at the

base................................ pulchella.

Lobes of the leaves $5-8 \mathrm{~cm}$. long; large vines.

Leaves parted to the base, the terminal lobe 3-parted....I. heterodoxa.

Leaves not parted to the base, the lobes all entire.......... digitata.

Leaves entire, or lobate to the middle or usually much less deeply, rarely more deeply lobate (I. stolonifera) but the plants then creeping.

Plants prostrate or creeping, not twining, herbaceous.

Leaf blades cordate or sagittate at the base.

Sepals pilose or ciliate, about $2 \mathrm{~mm}$. long . . . . . . .I. minutiflora. Sepals glabrous, $5-10 \mathrm{~mm}$. long.

Leaves sagittate. ..................... reptans.

Leaves rounded-cordate................... asarifolia.

Leaf blades rounded at the base.

Flowers white; leaves mostly oblong, sometimes deeply lobate, mostly 1-2 cm. wide. . . . . . . . . . . . . . . ...... stolonifera.

Flowers pink or purple; leaves suborbicular, mostly $6 \mathrm{~cm}$. wide or more, never lobate........................ pes-caprae.

Plants twining or trailing, at least the tips twining.

Sepals in anthesis $5 \mathrm{~mm}$. or less long; corolla blue to purple or yellow.

Corolla blue or pink to purple.

Calyx rugose on dorsal veins; corolla blue or purple, about $20-25 \mathrm{~mm}$. long.......................... aristolochiaefolia.

Calyx lobes not rugose; corolla pink, about $15 \mathrm{~mm}$. long..I. perplexa.

Corolla yellow, $8-25 \mathrm{~mm}$. long. 
Corolla about $8 \mathrm{~mm}$. long; leaves mostly as broad as long, rounded at the apex or abruptly acute; plants of ten prostrate.

I. minutiflora.

Corolla 20-25 mm. long; leaves longer than broad, acute or acuminate; plants twining.................. microsepala.

Sepals in anthesis $5 \mathrm{~mm}$. long or usually much longer; corolla rarely yellow.

Corolla yellow or orange.

Calyx lobes elliptic or oblong, subequal, 3-4 mm. broad... I. flavida.

Calyx lobes broadly ovate to suborbicular, unequal, more than $4 \mathrm{~mm}$. broad.

I. aurantiaca.

Corolla never yellow.

Leaves densely and conspicuously tomentose or sericeous beneath.

Corolla glabrous or essentially so.

Sepals aristate at the apex............. leucotricha.

Sepals rounded at the apex, not aristate.

Sepals sericeous.

I. tuxtlensis.

Sepals glabrous.

Leaves sagittate; anthers near the base of the corolla.

I. squamosa.

Leaves not sagittate; anthers near middle of corolla.

Leaves cuneate at the base; flowers red or carmen.

Leaves cordate at base.

I. steerei.

Leaves suborbicular-ovate; flowers lilac.....I. teruae.

Leaves trilobate; flowers white with red, or red.

I. tuxtlensis.

Corolla copiously, often densely pilose.

Sepals $5-15 \mathrm{~mm}$. long; leaves glabrous or only slightly pubescent above.

Sepals narrowly lanceolate, acuminate; stems muriculate, pilose with brownish hairs; corolla purple....I. villifera.

Sepals suborbicular; stems pale, whitish tomentose at first; corolla violet-pink or white............. carnea.

Sepals almost or quite $2 \mathrm{~cm}$. long; leaves densely whitishtomentose on both surfaces............... praecana.

Leaves glabrous beneath or inconspicuously pubescent, never densely sericeous or tomentose.

Sepals conspicuously aristate at the apex.

Sepals minutely aculeolate along the costa; petioles minutely aculeolate; leaves triangular-hastate, entire....I. setifera.

Sepals and petioles not aculeolate; leaves not triangular-hastate.

Sepals hirsute or at least ciliate............. triloba.

Sepals glabrous.

Stems mostly creeping and rooting, only the tips of the stems twining; plants usually not flowering.. I. batatas.

Stems not rooting at the nodes, twining throughout, the plants flowering abundantly.

Corolla about $2-3 \mathrm{~cm}$. long; leaves usually lobate.

I. trifida.

Corolla 3.5-7 cm. long; leaves usually not lobate.

Sepals $1 \mathrm{~cm}$. long or shorter. 
Corolla $3.5-5 \mathrm{~cm}$. long; stamens inserted below middle of the corolla; outer calyx lobes cochleate.

I. tiliacea.

Corolla 6-7 cm. long; stamens inserted near the throat; outer calyx lobes not cochleate.

I. seducta.

Sepals $1.3 \mathrm{~cm}$. long or longer.

Sepals oblong to oval, obtuse; peduncles about $1 \mathrm{~cm}$. long.................... santae-rosae.

Sepals narrowly lanceolate, subaristate; peduncle essentially none............... sessilis.

Sepals not aristate at the apex, usually rounded or obtuse.

Stems setose or setose-hispid.

Calyx lobes glabrous.

Calyx lobes ovate, obtuse, unequal, $10-20 \mathrm{~mm}$. long.

I. sepacuitensis.

Calyx lobes lanceolate to elliptic, acute, subequal, 25-30 mm. long.................. contrerasii.

Calyx lobes setese. . . . . . . . . . . . . . I. setosa.

Stems not setose nor setose-hispid.

Stems woody throughout; plants glabrous; corolla white.

Stems wholly or chiefly herbaceous.

I. paucifiora.

Flowers subtended by a large leaf-like reniform bract $2-5$ cm. long........................ suffulta.

Flowers never subtended by a large leaf like bract.

Sepals in anthesis about $5 \mathrm{~mm}$. long, narrow, lanceolate or ovate-lanceolate, imbricate only below.

Corolla glabrous outside, 5-6 cm. long; sepals mostly oblong-lanceolate, white marginate...I. tricolor.

Corolla puberulent outside, about $3 \mathrm{~cm}$. long; sepals lanceolate-ovate.............. parasitica.

Sepals in anthesis usually longer, mostly oval to orbicular, sometimes elliptic-oblong, usually strongly imbricated for most their length.

Upper leaves sessile or short-petiolate; corolla salverform..................... purga.

Upper leaves all or mostly long-petiolate; corolla funnelf orm.

Stems, at least below, bearing numerous fleshy tubercles; sepals $6 \mathrm{~mm}$. long.........I. parasitica.

Stems not tuberculate.

Leaves sagittate, the terminal portion oblong or triangular to almost linear.

Sepals very unequal, the outer ones less than half as long as the inner; peduncles severalflowered...I. anisomeres var. sagittiformis.

Sepals subequal, the outer ones but little shorter than the inner; peduncles mostly 1 -flowered................... sagittata.

Leaves narrowly to broadly ovate, cordate.

Corolla 5-8 cm. long, white, pink, purple, or brown-purple.

Sepals $12-18 \mathrm{~mm}$. long. 
Peduncle less than $2 \mathrm{~cm}$. long; inflorescence 1-2-flowered........... armentalis.

Peduncle 10-20 cm. long; inflorescence usually many-flowered....I. demerariana.

Sepals 6-10 $\mathrm{mm}$. long.

Stems conspicuously papillate on older growth; stamens only a third as long as corolla.............. anisomeres.

Stems smooth; stamens extending to the middle of the corolla or beyond.

Seeds long-pectinate-pilose; corolla brown-purple.......I. armentalis.

Seeds glabrous or short-pubescent; corolla rose-purple or white.

Corolla purple; leaves glabrous or nearly so, or sparsely pubescent.

Peduncles 0-5 mm. long... I. lindenii.

Peduncles $70 \mathrm{~mm}$. long or usually much longer.

Corolla campanulate or funnelform; anthers not reaching the middle of corolla.

I. squamosa.

Corolla salverform; anthers reaching the throat or exserted.

I. signata.

Corolla white; leaves densely hirtellous beneath.............I. saxorum.

Corolla about $4-4.5 \mathrm{~cm}$. long, sometimes longer, usually white, sometimes tinged with pink or yellow.

Stems woody with age; under surface of leaf with microscopic black dots; sinus at base of leaf shallow.......I. microsticta.

Stems herbaceous; under surface of leaves without black dots.

Sinus at base of leaf shallow; flowers yellow. I. flavida.

Sinus at base of leaf deep; flowers not yellow................... wallii.

Ipomoea anisomeres Rob. \& Bartl. Proc. Am. Acad. 43: 57. 1907.

Moist or wet thickets at $500 \mathrm{~m}$. or less; Zacapa (type, Deam 318); Petén (Contreras 437). Possibly British Honduras. Mexico (Veracruz).

A slender herbaceous vine, glabrous, the stems to about $3 \mathrm{~mm}$. in diameter, smooth at first becoming prominently papillate with age. Leaves oblong-ovate to broadly ovate, acute or acuminate, cordate and the basal lobes broad and rounded, petioles slender, 3-6.5 cm. long; inflorescence several-many-flowered corymbs or cymes, the peduncles 4-14 cm. long, the pedicels slender, and up to $2.5 \mathrm{~cm}$. long, slightly thickened above; calyx coriaceous, up to about $1 \mathrm{~cm}$. long, the lobes very 
unequal, the outer ones orbicular or transversely oval, 1-3 $\mathrm{mm}$. long, the inner lobes oblong to ovate, obtuse, $8-10 \mathrm{~mm}$. long at anthesis; corolla white with a purple throat, narrowly infundibulif orm, about $7 \mathrm{~cm}$. long, the limb 4-5 cm. broad; stamens unequal in length, one-third as long as the corolla or less; style as long as the stamens; capsule unknown.

Two numbers, Deam 318 and 319 are cited as types. We select 318 as the lectotype in Gray Herbarium.

Ipomoea anisomeres var. sagittiformis L. Wms. Fieldiana, Bot. 32:185. 1970.

Trailing on the ground or in thickets, $600 \mathrm{~m}$. or less, Izabal (type Steyermark 38485). Endemic.

Like the typical variety described above except: leaves smaller, sagittiform, pubescent, about $8 \mathrm{~cm}$. long with the terminal lobe linear-oblong, about 1-2 cm. broad; the exterior calyx lobes $3-5 \mathrm{~mm}$. long; the corolla purple. The capsule is suborbicular, about $1 \mathrm{~cm}$. long, the seeds subvelutinous with a longer sericeous coma along the lateral margins; these last characters not known for the typical variety.

Ipomoea arborescens (Humb. \& Bonpl.) G. Don, Gen. Syst. 4: 267. 1838. Convolvulus arborescens Humb. \& Bonpl. ex Willd. Enum. Pl. 1: 204. 1809.

Dry, rocky thickets, 900 m.; Chiquimula; Zacapa; Jutiapa (near Jutiapa, Standley 60491). Western and southern Mexico. El Salvador.

Small tree, the branches densely and minutely puberulent, the bark whitish; leaves slender-petiolate, ovate or oblong-ovate, mostly $5-14 \mathrm{~cm}$. long, acute or acuminate, shallowly cordate at the base, finely pubescent above or glabrate, densely and minutely pubescent beneath, the veins conspicuous and closely reticulate; peduncles usually short and several-flowered; sepals oval, obtuse or rounded at the apex, 8-12 mm. long, tomentulose; corolla white, $5 \mathrm{~cm}$. long, glabrous or glabrate outside; capsule ovoid, $2 \mathrm{~cm}$. long; seeds black, the angles densely longpilose.

Three collections of this species have been made in Guatemala, one by the senior author, and on the label it is stated that the tree is abundant about Jutiapa. The specimen is immature and may well be this species, which is known to occur on both sides of Guatemala, or it could be the common I. murucoides. The peduncles in $I$. arborescens are usually several flowered while those of $I$. murucoides usually bear a single flower. 
Ipomoea aristolochiaefolia (HBK.) G. Don, Gen. Hist. Pl. 4: 277. 1838; O’Donell, Lilloa 29: 114, fig. 4. 1959. Convolvulus aristolochiaefolia HBK. Nov. Gen. \& Sp. Pl. 3:102. 1819. I. tuerckheimii Vatke ex Donn.-Sm. Bot. Gaz. 40: 8. 1905 (type from Cobán, Tuerckheim 386). Campanilla; quiebra cajete.

Moist thickets, 600-2,000 (?) m.; Alta Verapaz; Jalapa; Santa Rosa; Zacapa. Mexico; El Salvador; Costa Rica; Venezuela; Colombia and Ecuador to Argentina.

A slender vine, the stem puberulent with short, erect hairs, becoming glabrous, internodes 5-10 $\mathrm{cm}$. long. Leaves with short petioles $1-5 \mathrm{~cm}$. long, the blades $5-8 \mathrm{~cm}$. long and $2-4 \mathrm{~cm}$. broad, cordate, acuminate, glabrous or sparsely puberulent above; peduncle very slender, $3-6 \mathrm{~cm}$. long, puberulent or not, often passing between the basal lobes of leaf, usually several-flowered; sepals oval, acute or obtuse, rugose on the dorsal veins, nearly equal or the outer ones shortest, mostly $3-5 \mathrm{~mm}$. long; corolla campanulate, glabrous, $20-25 \mathrm{~mm}$. long; ovary conic, bilocular, the style longer than the stamens; capsule ovoid, $1 \mathrm{~cm}$. long, seeds pubescent, black or brown.

Ipomoea armentalis L. Wms. Fieldiana, Bot. 32: 185. 1970.

Thickets, cornfields and forest edges, 500-1,200 m.; Chiquimula; Jutiapa (type, Standley 76005); Escuintla; Huehuetenango. Mexico (Chiapas). Madre de maiz; campanilla.

Delicate twining herbaceous or suffrutescent vines with puberulent or glabrescent stems to about $1 \mathrm{~mm}$. in diameter. Leaves oblong-ovate to ovate, cordate, acuminate, pilose-puberulent on both surfaces, the blade $3-8 \mathrm{~cm}$. long and $1.5-$ $4.5 \mathrm{~cm}$. broad, petiole slender, shorter than the blade; inflorescence axillary, 1(rarely 2-) flowered, longer than the subtending leaf, peduncle $0.1-1.2 \mathrm{~cm}$. long, puberulent, the slender pedicels $1-4 \mathrm{~cm}$. long, puberulent; calyx about $1.5 \mathrm{~cm}$. long at anthesis and in fruit, coriaceous, glabrous, the lobes unequal to subequal, oblong or oblong-oblanceolate, obtuse, $8-12 \mathrm{~mm}$. long, with the outer lobes often shorter than the inner ones; corolla dark purple to blue, narrowly campanulate, about $5-6 \mathrm{~cm}$. long, tip of bud puberulent; capsule lanceolate-ovoid, the thick style base persisting, $1.5-2 \mathrm{~cm}$. long; seeds subtrigonous, black, puberulent over the whole surface, except the lateral margins with long coma of comb-like hairs, about $9 \mathrm{~mm}$. long and $4 \mathrm{~mm}$. broad.

The only species in Guatemala with the margins of the seeds pectinate-ciliate; the one-flowered inflorescences are uncommon in the genus.

Ipomoea asarifolia (Desr.) Roem. \& Schult. Syst. 4: 251. 1819. Convolvulus asarifolius Desr. in Lam. Encycl. 3: 562. 1789. Hierba del carbunclo.

Moist or wet, open places, $200 \mathrm{~m}$. or less; Petén (La Libertad). Mexico (Chiapas); Honduras; Panama; West Indies; South America; tropical Asia and Africa. 
Plants herbaceous, trailing, not twining, glabrous, the stems very coarse and thick, rooting at the nodes; leaves succulent, rounded-cordate or subreniform, often $10 \mathrm{~cm}$. broad, rounded at the apex, entire; peduncles short or elongate, several-flowered, the pedicels short or elongate, rather slender; sepals unequal, 5-10 mm. long, elliptic or oval, subcoriaceous, rounded at the apex, mucronate; corolla purple, 6-8 cm. long, glabrous; seeds blackish, glabrous.

This species is noteworthy for its irregular and interrupted distribution. It is frequent in Panama but apparently rare in other parts of continental North America, or at least has not been collected.

Ipomoea aurantiaca L. Wms. Fieldiana, Bot. 32: 187. 1970.

Moist slopes and thickets, alt. 1,000-2,000 m., known only from Chiapas (Breedlove 13362, type) and from Huehuetenango (Steyermark 51015).

Delicate twining glabrous herbs with stems to about $2 \mathrm{~mm}$. in diameter. Leaves oblong-lanceolate, acuminate, truncate at the base, membranaceous or submembranaceous, the blade when mature $4.5-12 \mathrm{~cm}$. long and $1.5-6 \mathrm{~cm}$. broad, the petioles very slender $(0.5 \mathrm{~mm}$. in diameter $), 1-1.5(4) \mathrm{cm}$. long; inflorescence axillary, about as long as or longer than the subtending leaves, few-flowered, basically cymose, the peduncle about as thick as the stem, $2.5-7 \mathrm{~cm}$. long, the pedicels slender, somewhat furfurescent, mostly less than $2 \mathrm{~cm}$. long; calyx about 8-10 $\mathrm{mm}$. long, the lobes unequal, broadly ovate to suborbicular, obtuse, coriaceous, the outer ones somewhat furfurescent dorsally, 4-6 $\mathrm{mm}$. long, the inner lobes 8-10 mm. long, the margins chartaceous; corolla orange or yellow, tubularcampanulate, glabrous, $5-6 \mathrm{~cm}$. long and about $1 \mathrm{~cm}$. in diameter near the throat, lobes broadly ovate, about $1 \mathrm{~cm}$. long; capsule unknown.

There are only two species of Ipomoea in Guatemala with large yellow flowers - this and I. flaivda.

Ipomoea batatas (L.) Poir. Encycl. 6: 14. 1804. Convolvulus batatas L. Sp. Pl. 154. 1753. Camote; is or iz (Quiché, Maya, Quecchí); iis (Ixil); on (Jacaltec, Chuje); om (Poconchí). Sweet potato.

Cultivated commonly at low and middle elevations, and often naturalized in waste ground or moist thickets or fields; perhaps native of America, now cultivated in most warmer regions of the earth; noted as escaped in Sacatepéquez and Quezaltenango, and doubtless to be found in various other departments.

Perennial from a large fleshy root, glabrous or nearly so; stems usually trailing, a meter long or more; leaves very variable in outline, ovate to rounded, cordate at the base, entire or dentate or lobate, of ten deeply lobate, with acute lobes; peduncles equaling or shorter than the petioles, few-flowered; sepals oblong, acute or rounded and cuspidulate, 7-10 $\mathrm{mm}$. long, somewhat unequal; corolla pale purple or almost wholly white, about $5 \mathrm{~cm}$. long, glabrous; capsule 2-celled, glabrous; seeds glabrous.

The usual name for the sweet potato in Mexico and Central America is "camote," a word of Nahuatl origin. In Cuba this vege- 
table is called "boniato," a word said to be of Antillean origin. In Puerto Rico and in other parts of tropical America it is called "batata," perhaps a Carib word. It may be noted that the term batata belongs properly to the sweet potato, but in Central America and elsewhere it was transferred to the Irish potato when that was introduced from South America, and in most parts of the earth the Irish potato now is known by the name that belongs rightfully to the sweet potato. The name of this plant has given its name to a pueblo of the Department of Chiquimula, Camotán. Sweet potatoes are grown abundantly in some parts of Guatemala and large quantities are eaten, but they are not a highly important food, and in some regions they seldom are seen. The only departments with a large production are Alta Verapaz, Sacatepéquez, Izabal, and Petén. Although often of good quality, most of the local sweet potatoes are small, compared with those marketed in the United States. They of ten are sold boiled in the markets, and by the upland Indians are eaten more or less as a delicacy. In Guatemala sweet potatoes are especially esteemed for preparing a dessert known as dulce de camote, which sometimes is rather good, but generally is too highly flavored with cinnamon. There are a number of distinct color varieties of sweet potatoes in Guatemala. A camote blanco when grated or mashed is almost snow-white when cooked, and is much esteemed for desserts, likewise the camote morado, which is of a handsome deep purple color when put on the table. The sweet potato doubtless has been grown in Central America for many centuries. It is closely related to 1. tiliacea, and is believed by some persons to have originated from that species. In cultivation the plants often bear no flowers, and fertile capsules are a great rarity.

Ipomoea capillacea (HBK.) G. Don, Gen. Syst. 4: 267. 1838. Convolvulus capillaceus HBK. Nov. Gen. \& Sp. 3: 97. Feb. 1819. Ipomoea muricata Cav. Icon. 5: 52, t. 478, fig. 2. 1799, non Jacq. 1798. I. armata Roem. \& Schult. Syst. 4: 214. Spring 1819. I. muricatisepala Matuda, An. Inst. Biol. Méx. 34: 124. 1964, nom. illeg.

Open grassy places in pine forest, sometimes in wet meadows or on limestone, 800-2,000 m.; Zacapa; Chiquimula; Guatemala; Quiché; Huehuetenango. Southwestern United States; Mexico; El Salvador; Honduras; Costa Rica; Panama. Northwestern South America.

Perennial from a small tuberous root, the stems erect, simple or sparsely branched, usually $40 \mathrm{~cm}$. long or less, glabrous throughout or nearly so; leaves sessile, pedately parted into filiform segments $1-2 \mathrm{~cm}$. long; peduncles equaling 
or shorter than the leaves; inflorescence 1-flowered; sepals 4-5 $\mathrm{mm}$. long, oval or broadly ovate, obtuse, sparsely or densely muricate dorsally; corolla bright pink or purple, about $2.5 \mathrm{~cm}$. long; capsule globose, glabrous, $4-5 \mathrm{~mm}$. long; seeds minutely puberulent.

Easy of recognition by the erect habit, small flowers, and filiform divisions of the leaves. Called "pinito" in El Salvador.

Ipomoea carnea Jacq. Enum. Pl. Carib. 13. 1760.

Rocky brushy hillsides, 200-500 m.; Zacapa. Mexico (Yucatan); Nicaragua; Costa Rica; West Indies; northern South America.

A large woody vine, the branches usually stout and thick, pale, whitishtomentose at first; leaves broadly ovate to suborbicular, $5-15 \mathrm{~cm}$. long, rounded and apiculate at the apex or subacute, shallowly cordate at the base, pilosulous and densely puncticulate above or glabrate, pale-tomentose beneath, petiole usually shorter than the blade; peduncles about equaling the petioles or shorter, several-flowered; sepals suborbicular, $5 \mathrm{~mm}$. long, tomentose; corolla violet-pink or white, 4-7 cm. long, pilose outside; capsule ovoid, $1.5 \mathrm{~cm}$. long, glabrous; seeds densely covered with very long, soft, spreading hairs.

The Maya name of Yucatan is recorded as "chocobcat."

Ipomoea contrerasii L. Wms. Fieldiana, Bot. 32: 1891970.

Thickets at 300 meters or less, Petén (type, Contreras 3640).

Twining herbaceous vines, the slender stems, the petioles and the peduncles with long spreading hirsute pubescence, the hairs 4-5 mm. long. Leaves broadly ovate-cordate, short acuminate, with $6-8$ pairs of lateral nerves, the blades 8-12 $\mathrm{cm}$. long and 7.5-10 $\mathrm{cm}$. broad, glabrous, submembranaceous, cordate base very open, the petioles slender, hirsute, $9-11 \mathrm{~cm}$. long; inflorescence axillary, 1-flowered, the peduncles $4-5 \mathrm{~cm}$. long, hirsute, pedicels $3-4.5 \mathrm{~cm}$. long, swollen upward (inflated?), glabrous, $4-5 \mathrm{~mm}$. in diameter at the apex; sepals chartaceous, the margins thin and membranaceous, about equal in length, narrowly oblong-lanceolate, acute, $2.5-3 \mathrm{~cm}$. long and $0.8-1 \mathrm{~cm}$. broad; corolla blue, campanulate, the limb rotate, $10-12 \mathrm{~cm}$. long in anthesis, glabrous, stamens inserted about $2.5 \mathrm{~cm}$. above the base of the corolla, the filaments bearded at the base, the anthers reaching to about the middle of the corolla or less; capsule unknown.

This is one of the largest flowered of the Guatemalan morning glories, easily distinguished by a combination of large flowers, spreading hairs on the stems, petioles and peduncles, and the large calyx.

Ipomoea costellata Torr. Bot. Mex. Bound. Surv. 149. 1859.

Brushy plains or limestone hillsides, 250-1,500 m.; Zacapa; Chiquimula; Huehuetenango. Southwestern United States; Mexico.

Plants annual, erect or ascending, the larger plants twining, very sparsely pilosulous or almost glabrous; leaves small, short petiolate, cleft almost to the base 
into several linear, entire or lobate segments $1.5 \mathrm{~cm}$. long or shorter, strigillose; peduncles filiform, longer than the leaves, 1-flowered; sepals subequal, $4 \mathrm{~mm}$. long, linear-oblong or lance-oblong, acute, glabrous, subcoriaceous; corolla $12 \mathrm{~mm}$. long, glabrous, the limb purple, the tube white; capsule subglohose, $6 \mathrm{~mm}$. long; seeds glabrous.

This is a diminutive plant, in general appearance unlike most Central American Ipomoeas, but several similar species occur in Mexico.

Ipomoea crinicalyx S. Moore, Trans. Linn. Soc. II. 4: 402, t. 27, f. 1. 1895; O’Donell, Lilloa 29: 139, t. 9. 1959. I. seleri Millsp. Bot. Jahrb. 36, Beibl. 80: 23. 1905 (type from Yucatan).

British Honduras (El Cayo). Southern Mexico; Brazil; Argentina.

A small or large, herbaceous vine, glabrous or sparsely short-pilose; leaves long-petiolate, rounded-cordate, abruptly acuminate, shallowly or deeply cordate at the base, entire, more or less punctate and minutely papillose beneath along the linear-oblong or lance-oblong, acute, glabrous, subcoriaceous; corolla $12 \mathrm{~mm}$. veins; peduncles shorter or longer than the petioles, inflorescence a 1 -few-flowered cyme, the pedicels slender, usually elongate, minutely puberulent; sepals herbaceous, about $1.5 \mathrm{~cm}$. long, acute or obtuse, puberulent and puncticulate, densely covered with long spreading green fleshy spine-like appendages; corolla purple or blue, glabrous, 6-9 cm. long; capsule ovoid, glabrous, $12-15 \mathrm{~mm}$. long; seeds pilose on the angles.

Ipomoea demerariana Choisy in DC. Prodr. 9: 361. 1845.

Wet thickets or forest, often in wooded swamps, $700 \mathrm{~m}$. or usually less; Izabal; Alta Verapaz. British Honduras; along the Atlantic coast to Panama; Lesser Antilles; northern South America.

A large vine, sometimes climbing to a height of 15 meters, herbaceous or somewhat woody below, the stems as much as $2.5 \mathrm{~cm}$. thick, glabrous or nearly so; leaves long-petiolate, rounded-cordate, $8-20 \mathrm{~cm}$. broad, abruptly acute or cuspidate-acuminate, often purplish beneath, shallowly or deeply cordate at the base, glabrate, sometimes short-pilose beneath along the veins; peduncles $10-20 \mathrm{~cm}$. long or more, usually many-flowered; sepals broadly ovate, $15-18 \mathrm{~mm}$. long, obtuse or subacute, purple or lavender, finely pubescent or almost glabrous, subequal; corolla 5-8 cm. long, purple, glabrous; capsule subglobose, glabrous, $1 \mathrm{~cm}$. long; seeds covered with long soft hairs.

This is an exceptionally showy and handsome morning-glory, and attains perhaps a greater size than any other Guatemalan species. It has been confused, rather strangely, with Stictocardia campanulata (L.) House, and has been reported from British Honduras and Panama under that name. Stictocardia, so far as available records indicate, is not found north of Costa Rica and Panama. 
Ipomoea digitata L. Syst. ed. 10. 924. 1759.

Wet thickets, at or little above sea level; Izabal. British Honduras; Honduras; Panama; West Indies; South America; Old World tropics.

A stout vine, usually herbaceous, sometimes woody below, the stems sparsely pubescent or glabrous; leaves slender-petiolate, somewhat succulent, palmately lobate to or (ours) below the middle, cordate or truncate at the base, the lobes usually $5-7$, ovate or lanceolate, acute or acuminate, entire, $5-8 \mathrm{~cm}$. long, glabrous or sparsely pilose, pale beneath; peduncles usually longer than the petioles, pilosulous or glabrous; inflorescence cymose, few-several-flowered; pedicels much longer than the calyx; sepals equal, orbicular, subcoriaceous, $8-10 \mathrm{~mm}$. long, glabrous or sparsely pubescent; corolla rose-pink, 4-6 cm. long, glabrous; ovary glabrous, 2celled; seeds 4, long-pilose.

Known in Guatemala, Honduras, and British Honduras at sea level and doubtless will be found along the Atlantic shore in Nicaragua and Costa Rica. It is rare in collections.

Ipomoea fistulosa Mart. ex Choisy, DC. Prodr. 9: 349. 1845; O'Donell, Lilloa 29: 157, fig. 15. 1959. Batatas ? crassicaulis Benth. Voy. Sulph. 5: 134. 1845. Ipomoea crassicaulis Rob. Proc. Am. Acad. Sci. 51:530.1916. Campanilla; mañanita; campana; campanula lila.

Usually in wet, open ground, especially in marshes about lakes or along streams, often becoming naturalized in thickets, $1,000 \mathrm{~m}$. or less; found wild in Petén; Izabal; Chiquimula; Jutiapa; San Marcos; and probably elsewhere; cultivated commonly for ornament in parks and gardens of many parts of Guatemala. Southwestern Texas; Mexico; British Honduras; El Salvador to Costa Rica; Panama; South America; Old World.

An erect herb or shrub, sometimes $2.5 \mathrm{~m}$. high or even more, the stems stout, minutely puberulent or glabrous, fistulose; leaves long-petiolate, lance-cordate or narrowly ovate-cordate, $10-25 \mathrm{~cm}$. long, very narrowly long-acuminate, shallowly cordate at the base, entire, minutely puberulent or glabrous; peduncles little longer than the petioles, several-flowered, the pedicels short or elongate, thick; sepals subcoriaceous, suborbicular, $5-6 \mathrm{~mm}$. long, minutely puberulent or glabrate; corolla deep pink or rose-purple, finely tomentulose, $5-8 \mathrm{~cm}$. long; capsule subglobose, $2 \mathrm{~cm}$. long or smaller, glabrous; seeds covered with very long, soft, spreading hairs.

Sometimes called "campanilla de árbol" and "campanola" in El Salvador. The plant is not a particularly handsome or showy one, but it is much planted in Guatemalan gardens, perhaps because it thrives in spite of neglect. Its natural habitat in Central America seems to be marshes about the borders of lakes, but it grows well, even during the dry season, in well drained soil. 
Dr. O'Donell, l. c., believes that this species is native only in South America but has been introduced as an ornamental plant in North America and to other continents. It has the appearance of a native plant in Guatemala.

Ipomoea flavida L. Wms. Fieldiana, Bot. 32: 190. 1970.

Probably moist thickets and forest edges, alt. about $1,000 \mathrm{~m}$.; known only from the type (Tuerckheim 3930); Alta Verapaz. Endemic.

Slender herbaceous vines with minutely puberulent stems to about $2 \mathrm{~mm}$. in diameter. Leaves ovate, the base shallowly cordate, apex acuminate, glabrous or puberulent along or on the veins, principal lateral veins 5 alternate pairs, blade $3.5-11 \mathrm{~cm}$. long and $2-7.5 \mathrm{~cm}$. broad, petioles slender, puberulent, $2-6 \mathrm{~cm}$. long; inflorescence axillary, corymbiform, mostly 5-7-flowered, shorter or subequal to the subtending leaves, peduncles $0.2-2 \mathrm{~cm}$. long, the pedicels slender, at anthesis about 2-2.5 $\mathrm{cm}$. long; calyx about $12 \mathrm{~mm}$. long, the lobes elliptic-oblong, obtuse, coriaceous, subequal and $3-4 \mathrm{~mm}$. broad, the outer dorsally puberulent or pilosulose, the inner glabrous or nearly so; corolla narrowly infundibuliform, bright sulphur-yellow, glabrous except tip of lobes, about $4.5 \mathrm{~cm}$. long and $1.5 \mathrm{~cm}$. broad, contracted to a short narrow tube at the calyx, anther reaching to about the middle of corolla, about $5 \mathrm{~mm}$. long, the style reaching middle of the corolla; capsule and seeds unknown.

The only Ipomoea in Guatemala with large yellow flowers. Another occurs in Mexico (Chiapas).

Ipomoea heterodoxa Standl. \& Steyerm. Field Mus. Bot. 23: 82. 1944.

British Honduras, in moist thickets or open forest, little above sea level; type from Maskall, Gentle 971. Mexico (Yucatan; Campeche).

A slender twining herb, glabrous throughout; leaves long-petiolate, digitately 5-7-foliolate, the lower leaflets short-petiolulate or sessile, oblanceolate or linearoblanceolate, $4-8.5 \mathrm{~cm}$. long, $8-18 \mathrm{~mm}$. broad, slightly narrowed to the obtuse apex, attenuate to the base, entire; terminal leaflets 6-12 cm. long, deeply 3-parted, often almost to the base, cuneately long-attenuate at the base, the lobes entire; inflorescence a few-several-flowered cyme exceeded by leaf petioles, the peduncle to $1.5 \mathrm{~cm}$. long, the slender pedicels less than $1 \mathrm{~cm}$. long; sepals unequal, subcoriaceous, oval or suborbicular, the inner ones $5-6 \mathrm{~mm}$. long, rounded and muticous at the apex, the outer ones somewhat shorter; corolla white tinged with pink, or pale pink throughout, glabrous, $3.5-4 \mathrm{~cm}$. long, the limb scarcely more than $1.5 \mathrm{~cm}$. broad; capsule glabrous, ellipsoid-ovoid, $1 \mathrm{~cm}$. long; seeds covered with long soft spreading hairs.

A curious species allied to $I$. cairica (L.) Sweet. 
Ipomoea indica (Burm.) Merrill, Int. Rumph. Herb. Amb. 445. 1917. Convolvulus indicus Burm. Index Universalis Herb. Amb. 7: [6]. 1755. Ipomoea congesta R. Br. Fl. Nov. Holl. ed. 1, 485. 1810; O’Donell, Lilloa 29: 134. 1959. Convolvulus acuminatus Vahl, Symb. Bot. 3: 26. 1794. Ipomoea cathartica Poir. in Lam. Encycl. Méth. Suppl. 4:633. 1816. I. acuminata Roem. \& Schult. Syst. Veg. 4: 228. 1819, non I. acuminata Ruiz \& Pavón, 1799. I. vahliana House, Ann. N. Y. Acad. Sci. 18: 204. 1908. Quilamul; sayún (Cobán, Quecchí).

Moist or wet thickets, often a weed in second growth or in abandoned fields or hedge rows, 1,400 m. or less; Petén; Alta Verapaz; Zacapa; Sacatepéquez; Suchitepéquez; Retalhuleu; Huehuetanango; San Marcos; doubtless in other departments. British Honduras. Pantropical, the type from southeast Asia, and widely cultivated. In America from the southern United States to Argentina.

Plants herbaceous, twining, much branched and of ten elongated, rarely prostrate, the stems appressed-pilosulose to glabrate; leaves rounded-ovate, mostly 5-9 cm. long, usually acuminate, cordate at the base, entire or rarely trilobate, appressed-pilosulous or glabrate; peduncles $2-20 \mathrm{~cm}$. long, mostly shorter than the petioles but sometimes longer; inflorescences 1-few-flowered cymes; sepals pale green, herbaceous at least toward the apex, lance-ovate or ovate, 1-2 cm. long, 3-7 mm. broad, acuminate or long-acuminate, appressed-pilosulous or usually glabrate; corolla blue or purple, rarely white, glabrous outside, $5-7 \mathrm{~cm}$. long or even larger, the limb 6-8 cm. broad; capsule globose, $1 \mathrm{~cm}$. broad or less, glabrous; seeds glabrous, $3 \mathrm{~mm}$. long.

Called "gloria de la mañana" in British Honduras, a translation of the English name that has come into use along the banana coast of Central America, "quiebra-platos" (Veracruz). The species is a variable one, especially in pubescence. House divided the material that we refer here into three species, but they cannot be separated definitely by the characters that he suggested.

Ipomoea indica var. variabilis (Schlecht. \& Cham.) L. Wms. Fieldiana, Bot. 32: 191. 1970. Convolvulus variabilis Schlecht. \& Cham. Linnaea 5: 116. 1830. Ipomoea variabilis Choisy in DC. Prodr. 9: 383. 1845.

Moist or wet thickets, $700 \mathrm{~m}$. or less; Izabal; Escuintla; San Marcos. Southern Mexico.

A slender herbaceous vine, the stems and leaves glabrous or nearly so; leaves thin, long-petiolate, cordate-ovate or triangular-ovate, 5-8 cm. long, acuminate or long-acuminate, rather shallowly cordate at the base, sometimes subhastate, entire; peduncles shorter than the petioles, 1-2 cm. long, 1-5-flowered, the bracts green, linear-lanceolate; sepals lanceolate or ovate-lanceolate, herbaceous, $12-15$ 
$\mathrm{mm}$. long, long-setose or subsetose at the base; corolla bright purple, $5-6 \mathrm{~cm}$. long, glabrous, with a very broad limb; capsule $8-10 \mathrm{~mm}$. in diameter; seeds glabrous.

Distinguished from the species by the long setose or subsetose hairs at the base of the calyx.

Ipomoea leucotricha Donn.-Sm. Bot. Gaz. 23: 10. 1897.

Alta Verapaz; type collected near Nentón, Heuhuetenango, $900-$ 1,200 m., Nelson 3512. Nicaragua; Costa Rica.

Plants twining, densely silvery-sericeous throughout except less so on the corollas and the upper leaf surface; leaves long-petiolate, orbicular-cordate, 7-12 cm. long, 6-10 cm. broad, entire or rarely lobate, sparsely pilose and green on the upper surface; peduncles longer than the leaves, with numerous flowers; bracts linearlanceolate, $6 \mathrm{~mm}$. long, the pedicels 1-2 $\mathrm{cm}$. long; sepals $6 \mathrm{~mm}$. long, subequal, oblong-ovate, with a recurved mucro at the apex; corolla purple, 5-7 cm. long and $2.5 \mathrm{~cm}$. broad at the throat, sericeous outside except in the plicae; ovary glabrous.

Ipomoea lindenii Mart. \& Gal. Bull. Acad. Brux. 12, 2: 264. 1845; Matuda, An. Inst. Biol. 36: 84. 1965.

Thickets. Guatemala, Escuintla, Standley 24406, according to Matuda. Mexico.

Twining plants with slender of ten suffruticose stems. Leaves cordate-ovate to subtriangular, acuminate, glabrous to sparsely pubescent along the veins, 5$10 \mathrm{~cm}$. long and $2-6 \mathrm{~cm}$. broad, petioles slender, $3-5 \mathrm{~cm}$. long; inflorescence axillary, 1-2-flowered, the peduncles 1-5 $\mathrm{mm}$. long, the pedicels to about $15 \mathrm{~mm}$. long, glabrous to sparsely pilose; sepals unequal, oblong or lance-oblong, obtuse, 6-8 $\mathrm{mm}$. long, glabrous or nearly so; corolla infundibuliform to campanulate, glabrous except toward the tip, 5-6 cm. long.

Prof. Matuda, possibly in error, reports the species from Guatemala based on Standley 24406 in 1922.

Ipomoea mairetii Choisy in DC. Prodr. 9: 374. 1845. Quiebracajete.

Moist or rather dry thickets or forest, of ten in pine-oak forest, 650-1,900 m.; Zacapa; Chiquimula; Jalapa; Jutiapa; Santa Rosa; Guatemala; Sololá; Sacatepéquez; Chimaltenango. Southern Mexico.

A woody vine, of ten large and climbing over trees, the stems densely sericeous or somewhat tomentose; leaves long-petiolate, rounded-ovate or subreniform, 7$15 \mathrm{~cm}$. long or larger, acute or acuminate, shallowly or deeply cordate at the base, of ten trilobate, usually green above and rather densely appressed-pilose, very densely silvery-sericeous beneath; peduncles several-flowered, equaling or shorter than the leaves, the inflorescence a few-flowered cyme, open or dense, the bracts large, ovate, acute or acuminate, persistent, the pedicels $1-3 \mathrm{~cm}$. long; sepals ovate or broadly ovate, $2-2.5 \mathrm{~cm}$. long, acute, densely sericeous; corolla bright rose- 
purple, $7-8 \mathrm{~cm}$. long, the tube densely white-pilose outside; capsule glabrous, globose, $1 \mathrm{~cm}$. in diameter; seeds blackish, densely and finely pubescent.

One of the handsomest of the local Ipomoea species, abundant at many places in the central region at middle elevations, often growing in thin oak forest. It has been reported from Guatemala as $I$. tyrianthina Lindl.

Ipomoea meyeri (Spreng.) G. Don, Gen. Syst. 4: 275. 1838. Convolvulus meyeri Spreng. Syst. 1: 597. 1825. I. chiapensis Brandegee in Univ. Calif. Publ. Bot. 6: 60. 1914 (type from Tonalá, Chiapas). I. brachypoda Benth. Bot. Voy. Sulph. 135. 1844.

Moist thickets, 150-500 m.; Alta Verapaz; El Progreso; Zacapa; Chiquimula; Santa Rosa. Southern Mexico; British Honduras; Honduras; Costa Rica; Panama; West Indies; northern South America.

A small, slender herbaceous vine, the stems glabrous or sparsely pilose; leaves slender-petiolate or the upper ones short-petiolate, broadly or narrowly ovate, 4$10 \mathrm{~cm}$. long, acute or acuminate, cordate at the base, entire or hastately trilobate, glabrate, of ten white-puncticulate beneath; inflorescence a few-several-flowered cyme as long as or usually shorter than the subtending leaf, peduncles to $6 \mathrm{~cm}$. long (usually much shorter in Guatemalan material), the pedicels short, bracts linear; sepals 1-2 cm. long, linear-lanceolate, acuminate, pilose or hirsute with long pale spreading hairs with tuberculate bases, green, herbaceous; corolla blue or purple with a white throat, $2.5-3 \mathrm{~cm}$. long, glabrous; capsule globose, $8 \mathrm{~mm}$. in diameter; seeds densely and finely pubescent.

Called "camotillo" in British Honduras; the Maya names "tsusuc" and "xhail" are reported from Yucatan. In Honduras called "campanilla."

Ipomoea microsepala Benth. Bot. Voy. Sulph. 136. 1844. Principe amarillo.

Wet to dry, sometimes rocky thickets, 1,600 m. or less; Sololá; Sacatepéquez; Suchitepéquez; Retalhuleu; San Marcos. Western and southern Mexico.

A small, slender herbaceous vine, climbing over shrubs, the stems sparsely hirsute with long spreading hairs or glabrous; lower leaves long-petiolate, the upper on very short petioles, broadly ovate, mostly $3-6 \mathrm{~cm}$. long, acuminate to obtuse, deeply cordate at the base, entire, glabrous or nearly so; inflorescence a few-flowered axillary cyme on usually long almost filiform peduncles exceeding the leaves, the pedicels subfiliform, mostly less than $1 \mathrm{~cm}$. long; sepals subequal, oblong, obtuse, sphacelate, about $2 \mathrm{~mm}$. long and $1 \mathrm{~mm}$. broad; corolla bright yellow, 2-2.5 cm. long; capsule subglobose; seeds densely short-pilose.

A common plant of the western Pacific plains, easily recognized by the small yellow flowers and elongate twining stems and very small, sphacelate sepals. 
Ipomoea microsticta Hallier f. Bull. Herb. Boiss. ser. 1, 7: 411. 1899; L. Wms. Fieldiana, Bot. 32: 191. 1970. I. glabriuscula House, Bot. Gaz. 43: 409. 1907.

Moist thickets or forest edges, 325-1,200 m.; Escuintla (type Seler \& Seler 2427); Suchitepéquez; Sacatepéquez; Santa Rosa; Chiquimula; Jutiapa. Mexico; British Honduras; Costa Rica.

Herbaceous or suffrutescent vines, the branches becoming quite woody with age, glabrous, terete. Leaves broadly ovate to suborbicular, shallowly cordate, acuminate, obscurely puberulent below or glabrous, provided with abundant microscopic "glands" below, the blades $3-10 \mathrm{~cm}$. long and $2.5-11 \mathrm{~cm}$. broad, the petioles $2.5-6 \mathrm{~cm}$. long, slender, usually with two inconspicuous glands at the apex; inflorescence a 1-several-flowered axillary cyme, the peduncles $2-8 \mathrm{~cm}$. long, the pedicels about $1 \mathrm{~cm}$. long, angulate, subclavate; calyx subglobose, glabrous, the sepals broadly elliptic to suborbicular, subcoriaceous, cochleate to somewhat concave, 6-8 mm. long; corolla campanulate, glabrous, pale pink to white, 4-5 cm. long; stamens inserted near the base of the corolla and about a third as long; style exceeding the stamens; capsules broadly ovate, somewhat attenuate to the persistent base of the style, $10-15 \mathrm{~mm}$. long.

Said by Standley to be one of the most attractive morning-glories of Guatemala. The campanulate corolla, subglobose calyx, and shallowly cordate leaves are distinctive marks of this species.

The small "glands," described by Hallier, from the undersurface of the leaves are on all the specimens we have seen. However, we are not sure that these are not caused by a fungus.

Ipomoea minutiflora (Mart. \& Gal.) House, Muhlenbergia 5: 71. 1909. Convolulus minutiflorus Mart. \& Gal. Bull. Acad. Brux. 12, pt. 2: 262. 1845. I. filipes Benth. ex Meissn. in Mart. Fl. Bras. 7: 274. 1869.

Moist shaded banks, brushy rocky slopes, wet meadows, sometimes a weed in cultivated ground, 1,200 m. or less; Zacapa; Chiquimula; Jutiapa; Santa Rosa; Escuintla. Southern Mexico; British Honduras to Nicaragua and Costa Rica; northern South America.

Plants annual, usually prostrate, very slender, the stems pilose or glabrate, of ten densely leafy; leaf blades broadly ovate to subreniform, 1-3(-6.5) cm. long, acute to rounded at the apex, shallowly or deeply cordate at the base, entire or somewhat angulate, ciliate, sparsely pilosulous above, glabrous beneath, long-petiolate to almost sessile; peduncles filiform, 1-3-flowered, usually longer than the leaves, the pedicels recurved in fruit; sepals $2 \mathrm{~mm}$. long, acute, pilose; corolla yellow, 1-1.5 cm. long; capsule subglobose, glabrous, 4-5 mm. long; seeds blackish, minutely puberulent or glabrate.

An inconspicuous little plant, usually creeping, noteworthy for the very small, bright yellow corollas. It is to be expected in other departments. 
Ipomoea murucoides Roem. \& Schult. Syst. 4:248. 1819. Siete camisas; tonche; tutumuzco; tutumuste; siete pellejos; tutumuscuavo; palo blanco; siete capas; tutusmuscuago; tutumuzcual.

Brushy, open, dry, often rocky slopes or plains or in open dry forest, frequently in hedges, or in oak forest, 600-2,000 m.; Chiquimula; Jalapa; Jutiapa; Santa Rosa; Guatemala; Sacatepéquez; Quiché; Huehuetenango. Southern Mexico.

A tree, commonly 5-9 m. high, the crown low and spreading, the bark almost smooth, white, the branches thick, the young branches densely white-tomentose; leaves slender-petiolate, oblong-lanceolate, mostly 7-12 cm. long, long-acuminate, obtuse or rounded at the base, entire, somewhat tomentose when young but soon glabrate; inflorescence a white tomentose few-several-flowered terminal raceme, or single flowers borne in the axils of leaves, the peduncles as short as the petioles or almost none, the pedicels $2-4 \mathrm{~cm}$. long; sepals $2-3 \mathrm{~cm}$. long, subequal, coriaceous, rounded at the apex, tomentose outside, sericeous within; corolla pure white, 7$8 \mathrm{~cm}$. long, tomentose outside; capsule $2.5 \mathrm{~cm}$. long, ovoid, glabrous; margins of the seeds densely set with long soft spreading white hairs.

It is said that the ashes make the best lye for soap-making. Cattle are fond of the ashes, which they eat in place of salt. This species belongs to the group of tree Ipomoeas that grow so profusely in the dryer parts of western Mexico. It is common and conspicuous in the central region, especially about Antigua, where it is often planted for living fence posts or for hedges. It is more abundant in the west, and is conspicuous on the arid hills about Sacapulas in Quiché. The trees are conspicuous because of their white trunks and branches, which look as if they had been used as roosting places by birds. The abundant large white flowers are very handsome, and the trees are strangely unlike most members of the morning-glory family. The flowers apparently remain open all day long and, once open, probably do not close until they wither.

Ipomoea nil (L.) Roth, Cat. 1: 36. 1797; O’Donell, Lilloa 29: 197, t. 1959. Convolvulus nil L. Sp. Pl. ed.2.219.1762. Campanilla; campana.

Wet to dry, often rocky thickets, often in waste or cultivated ground, 1,750 m. or less; Zacapa; Chiquimula; Jutiapa; Santa Rosa; Sacatepéquez; Guatemala; Quiché; Huehuetenango. Florida; Mexico; British Honduras to Panama; West Indies; South America; Old World tropics.

A small or rather large, herbaceous vine, usually always annual, hirsute almost throughout with sparse or often dense, usually pustulate-based, unicellular, brownish hairs; leaves $5-15 \mathrm{~cm}$. long, shallowly or deeply cordate at the base, ovate to 


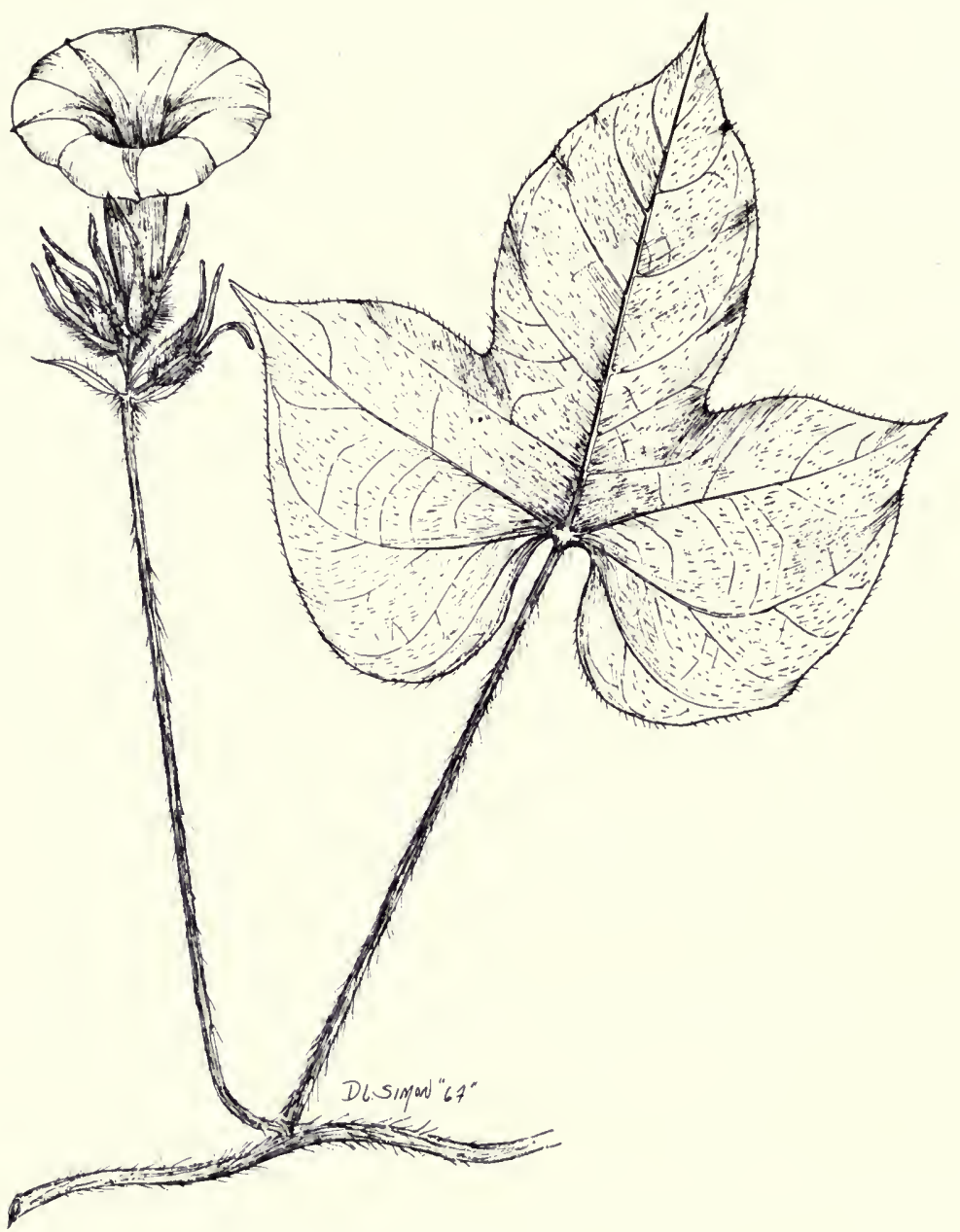

FIG. 5. Ipomoea nil. Habit of the plant, $\times 1 / 2$.

suborbicular, entire or trilobate (rarely 5-lobate), the lobes entire, abruptly acute or acuminate; inflorescence 2-5-flowered, cymose, dense and head-like, peduncles longer or shorter than the petioles; sepals subequal, $1.5-2.5 \mathrm{~cm}$. long, linear and herbaceous, the bases somewhat broadened, densely long-hirsute; corolla infundibuliform, blue or purple, $3-5 \mathrm{~cm}$. long, glabrous, the limb $4-5 \mathrm{~cm}$. broad; ovary 3 -celled; style 17-30 mm. long, stigma biglobular; capsule globose, 8-12 mm. long; seeds finely and densely pubescent.

One of the most common weedy species of Ipomoea through much of the lowlands of Central America. The Maya name "itzotz-cabil" is reported from Yucatan. 
Ipomoea ophiodes Standl. \& Steyerm. Field Mus. Bot. 23: 82. 1944.

Moist thickets or forest, $200-400 \mathrm{~m}$.; Santa Rosa (type from region of La Morenita, northeast of Chiquimulilla, Standley 78884). El Salvador.

A small herbaceous vine, the stems sometimes prostrate and rooting at the nodes, densely hirsute with very long, spreading hairs, the internodes elongate; leaves long-petiolate, cordate-ovate, $4-10 \mathrm{~cm}$. long, 3-6.5 cm. broad, acute or acuminate, hirsutulous above, slightly paler beneath and puberulent, the petioles puberulent and very sparsely hirsute; inflorescence 1-flowered, peduncles scarcely $1 \mathrm{~cm}$. long, the slender pedicels $2.5-3.5 \mathrm{~cm}$. long, minutely puberulent and very sparsely hirsute; sepals subequal, subherbaceous, $12 \mathrm{~mm}$. long, linear-lanceolate, acuminate, sparsely long-hirsute; corolla deep purple, 8-9 $\mathrm{cm}$. long, glabrous, the limb $8 \mathrm{~cm}$. broad.

Noteworthy for the very dense and long hairs of the stem, the pubescence of the leaves consisting wholly of short and inconspicuous hairs.

Ipomoea parasitica (HBK.) G. Don, Gen. Syst. 4: 275. 1838. Convolvulus parasiticus HBK. Nov. Gen. \& Sp. Pl. 3: 103. 1819. Campanilla; quebra-cajete.

Brushy slopes and thickets, 800-1,500 m.; Jalapa; Jutiapa; Santa Rosa. Mexico through Central America. Northern South America.

A small or large, herbaceous vine, the stems glabrous or nearly so, often bearing below wart-like fleshy tubercles; leaves long-petiolate, rounded-cordate, 6-10 $\mathrm{cm}$. long, acuminate or rounded and cuspidate at the apex, strigillose above, glabrous beneath or nearly so, the petioles rarely tuberculate; inflorescence 5-12flowered, peduncles shorter or slightly longer than the petioles, stout, the pedicels much thickened upward; sepals 4-5 mm. long, the outer ones lanceolate-ovate, subacute and minutely cuspidate, minutely appressed-pilosulous, the inner ones rounded; corolla sericeous outside, $3 \mathrm{~cm}$. long, bright purple; stamens reaching to about middle of the corolla; style as long as the stamens but breaking off shortly above the capsule after corolla falls; capsule ovoid-globose, $1 \mathrm{~cm}$. long; seeds minutely puberulent.

This species is very closely allied to $I$. tricolor Cav. but can be distinguished by the smaller corollas which are sericeous outside, and by the broader calyx lobes.

Ipomoea pauciflora Mart. \& Gal. Bull. Acad. Brux. $12^{2}: 266$. 1845; Walp. Rep. 6: 532. 1847; L. Wms. Fieldiana, Bot. 32: 192. 1970. Ipomoea populina House, Ann. N. Y. Acad. Sci. 18: 227. 1908.

Dry thickets and hills, 400-900 m.; Chimaltenango; Chiquimula; Progreso. Western and southern Mexico; Honduras; Nicaragua. 
A large vine, woody throughout, the stems sometimes $2 \mathrm{~cm}$. thick, glabrous or nearly so; leaves mostly ovate, entire, $5-8 \mathrm{~cm}$. long, acuminate or long-acuminate, rounded or very shallowly cordate at the base, glabrous or nearly so; inflorescence cymosely few-many-flowered, of ten on defoliate branches, peduncles $8-12 \mathrm{~cm}$. long, the pedicels $3 \mathrm{~cm}$. long or shorter; sepals subequal, rounded-ovate, $5-8 \mathrm{~mm}$. long, glabrous; corolla white, of ten with a dark red or purple throat, about $6 \mathrm{~cm}$. long, glabrous, the limb 6-8 cm. broad; capsule thick-walled, ellipsoid, $2 \mathrm{~cm}$. long, $1 \mathrm{~cm}$. thick, 4-valvate, 2-celled; seeds covered with long soft spreading white hairs.

A most attractive woody vine that is in flower in dry regions from about the end of the rainy season. It is exceedingly common in parts of central Honduras.

I pomoea perplexa L. Wms. Fieldiana, Bot. 32: 193. 1970.

In thickets, clearings, or forest edges, alt. up to $600 \mathrm{~m}$.; Petén. British Honduras (type, Bartlett 12868) and Honduras.

Slender twining herbaceous vines, stems about $1 \mathrm{~mm}$. or less in diameter, glabrous. Leaves glabrous, small, narrowly ovate to broadly ovate in outline, cordate, acute or acuminate, blade entire, dentate to trilobulate, $1.5-6 \mathrm{~cm}$. long and $0.6-$ $4.5 \mathrm{~cm}$. broad, petioles short, to about as long as the blade; inflorescence an axillary few-several-flowered corymb, peduncles about as thick as the stem, $1.5-6 \mathrm{~cm}$. long, pedicels relatively stout, less than $1 \mathrm{~cm}$. long; calyx coriaceous, glabrous, the lobes subequal, about $4 \mathrm{~mm}$. long, the outer ones usually somewhat shorter, oblong to oblong-obovate or obovate, obtuse or truncate, the margins somewhat char taceous, usually with a minute inframarginal apicule at the center; corolla small, pink or purple, narrowly funnelform, glabrous outside, 14-18 $\mathrm{mm}$. long, stamens inserted near the base of the corolla, unequal, reaching to about the middle, anthers 1-1.2 $\mathrm{mm}$. long, filaments bearded at the base, stigma globose (or biglobose), large, about $0.8 \mathrm{~mm}$. broad; capsule glabrous, subglobose, about $4-5 \mathrm{~mm}$. long; seeds brown or black, glabrous, smooth.

The smallest flowered of Central American Ipomoeas with pink or purplish flowers. It is distinguished by the small flowers and the small obtuse or truncate calyx lobes. The leaves are usually lobate but lobate and entire leaves occur on the same stem.

Ipomoea pes-caprae (L.) Sweet, Hort. Lond. 35. 1818. Convolvulus pes-caprae L. Sp. Pl. 159. 1753. See Figure 12.

On sea beaches; Izabal; Escuintla; Retalhuleu; San Marcos; doubtless in all coastal departments. Common on tropical seashores of both hemispheres.

Plants herbaceous, glabrous, somewhat succulent, the stems prostrate, thick, sometimes $20 \mathrm{~m}$. long or more, branched; leaves long-petiolate, suborbicular, 6$10 \mathrm{~cm}$. long, broadly rounded and emarginate at the apex, rounded or subcordate at the base, entire; inflorescence 1-several-flowered, peduncles stout, about equaling the petioles, usually bifid, the pedicels long, slender; sepals oval or suborbicular, $1 \mathrm{~cm}$. long, obtuse or rounded at the apex; corolla pink or purple, glabrous, $4-5 \mathrm{~cm}$. 
long, the limb 5-8 cm. broad; capsule ovoid-globose, $1.5 \mathrm{~cm}$. long; seeds densely pubescent.

One of the most characteristic and widely distributed of tropical strand plants, and found on most of the sandy seashores of Central America. The stems are coarse, rope-like, and strong, so that they can stand the wind and waves that prevail in such places. Along the Pacific coast of Guatemala the leaves and stems wither during the dry season.

American material of this species is said by van Ooststroom, and O'Donell seems to agree (Lilloa 30:46. 1960), to be a subspecies distinct from the typical subspecies which appears to be limited to east Africa, tropical Asia, and the Malay Archipeligo. An acceptable subspecific name for the American plant is subsp. brasiliensis (L.) Oosts. If a varietal rank is desired the proper name would seem to be var. emarginata Hallier f.

Ipomoea praecana House, Ann. N. Y. Acad. Sci. 18: 227. 1908.

Dry thickets or forest, 300-700 m. ; Zacapa; El Progreso. Southern Mexico; Honduras; Nicaragua.

A stout vine, woody throughout, the stems thick, densely whitish-tomentose; leaves on rather short petioles, suborbicular to broadly ovate, 7-20 cm. long, rounded to acute at the apex, shallowly cordate at the base, densely whitish-tomentose on both surfaces, thick; inflorescence 3 -5-flowered, peduncles equaling or shorter than the petioles, the pedicels $5-10 \mathrm{~mm}$. long; sepals $18-25 \mathrm{~mm}$. long, elliptic or oval, obtuse, densely white-tomentose outside, almost glabrous within; corolla white, 6-13 cm. long, sparsely or densely white-pilose outside, the limb 6-10 cm. broad.

Ipomoea pulchella Roth, Nov. Pl. Sp. 115. 1821; O'Donell, Lilloa 29: 221. 1959.

Moist thickets or open grassy places near lake shores, 500-600 m. ; Jutiapa. Circumtropical, in America from southern United States to Argentina.

Plants probably annual, very slender, twining or trailing, herbaceous, glabrous; leaves long-petiolate, pedately 5 -foliolate, the leaflets lanceolate or linear-lanceolate, sessile, 1-4 cm. long, acute, entire; peduncles filiform, equaling or of ten much longer than the petioles, spirally coiled, 1-flowered; sepals greenish, ovate or oval, 5-7 mm. long, obtuse or rounded at the apex; capsule globose, $8-10 \mathrm{~mm}$. long, glabrous; seeds finely pubescent.

This species may be recognized at once by the delicate, conspicuously coiled peduncles, a character not found in any other Ipomoea of Central America. 
Ipomoea purga (Wender.) Hayne, Arzn. Gew. 12: t. 33, 34. 1833; Convolvulus purga Wender. Pharm. Centralbl. 1: 457. 1830. Quilamul; quiebra-cajete; nacta (Quecchí).

Wet to dry thickets, often in waste ground or in hedges, $2,000 \mathrm{~m}$. or lower, most frequent at low elevations; Alta Verapaz; Izabal; Santa Rosa; Escuintla; Guatemala; Suchitepéquez; Retaljuleu; San Marcos. Southern Mexico; El Salvador and Honduras to Costa Rica.

Usually a large, herbaceous vine, glabrous throughout or nearly so; lower leaves long-petiolate, the upper ones almost sessile sometimes and clasping the stems; leaf blades ovate or broadly ovate, thin, mostly 5-11 cm. long, acute or acuminate, deeply cordate at the base, entire; peduncles usually longer than the subtending petioles, 1-2-flowered; sepals very unequal, the longest $8-9 \mathrm{~mm}$. long, oval, very obtuse and usually cuspidulate, glabrous; corolla red-purple or rose-purple, glabrous, salverform, $7-8 \mathrm{~cm}$. long, the tube slender, the limb rotate or nearly so.

Known in El Salvador as “campanilla," "campánula," and "mechoacán." This plant has long been known in pharmacy as the source of the drug jalap or jalapa, obtained from the roots, and formerly used extensively in medicine as a purgative. Large amounts of the crude drug have been exported from Mexico, and some amounts may still be exported to the United States. The purgative properties are believed to exist in a resin that may be separated from the large tuberous roots, which are merely dried for export. The plant was used in medicine by the ancient Mexicans, and perhaps by the people living farther southward. It is one of the handsomest of the Ipomoeas because of its brilliantly colored, red-purple flowers. A century and a half ago there was much confusion regarding the source of the drug jalap, and for a while it was believed that it was derived from Mirabilis jalapa, hence the erroneous drug name given to that plant.

Ipomoea purpurea (L.) Roth, Bot. Abh. 27. 1787. Convolvulus purpurea L. Sp. Pl. ed. 2, 219. 1762. Pharbitis diversifolius Lindl. Bot. Reg. 23: t. 1988. 1837. Ipomoea purpurea var. diversifolia O’Donell, Lilloa 26: 385, fig. 1953. Campanilla; quiebra-cajete; quilamul.

Moist thickets or hedges, often in second growth or waste ground, frequently a weed in cornfields, sometimes in oak forest, 1,300-2,100 m.; Alta Verapaz; Baja Verapaz; Jalapa; Escuintla; Guatemala; Sacatepéquez; Chimaltenango; Huehuetenango. United States; Mexico; El Salvador to Costa Rica; West Indies; South America; Old World tropics, where introduced. 
A slender herbaceous annual vine, the stems pilose or hirsute with spreading or retrorse hairs; leaves broadly ovate or rounded, shallowly or deeply cordate at the base, entire or often trilobate, long-petiolate, hirsute or hirsutulous on both surfaces, mostly 2-10 cm. long and about as broad; cymes 1-5-flowered, peduncles usually longer than the petioles, the pedicels short or elongate, sepals herbaceous, lanceolate or oblong-lanceolate, $8-16 \mathrm{~mm}$. long, acute, pilose or hirsute (especially at the base); corolla glabrous, blue, purple, pink, or white, sometimes with vertical stripes of different colors, $3-5 \mathrm{~cm}$. long; ovary usually 3-celled; capsule depressedglobose, $10 \mathrm{~mm}$. long; seeds black, glabrous.

In Central America this morning-glory does not seem to become so noxious a weed as it often does in the United States where it sometimes forms such dense tangles in cornfields that it is all but impossible to force one's way through them, and in late summer it often is necessary to cut and remove the vines before a potato crop can be harvested. Like all or most Ipomoeas, this is a handsome plant, and often is cultivated for ornament. In Guatemala they often are found in cultivation and sometimes as escapees from cultivation forms with "double" corollas, variously colored. Forms with cordate entire or trilobate leaves are common in Guatemala and sometimes both leaf forms are found on the same specimen.

Ipomoea reptans (L.) Poir. in Lam. Encycl. Suppl. 3: 460. 1813. Convolvulus reptans L. Sp. Pl. 158. 1753. I. aquatica Forsk. Fl. Aegypt. Arab. 44. 1775.

In wet soil or floating in water, at or little above sea level; British Honduras; Costa Rica; Panama; West Indies; South America; Old World tropics.

Plants herbaceous, the stems hollow, rooting at the nodes, trailing on wet soil or floating on water, glabrous or nearly so; leaves mostly hastate, with narrowly triangular or lanceolate, terminal lobes and small spreading basal lobes, acute or obtuse, shallowly cordate at the base, 4-12 cm. long, long-petiolate; peduncles short, 1-few-flowered, the pedicels slender and greatly elongate; sepals subequal, ovate-oblong, obtuse or subacute, mucronulate, glabrous, $7 \mathrm{~mm}$. long; corolla glabrous, purple, 4-5 cm. long, with a broad limb; capsule small, globose, with 4 or fewer seeds, these densely soft-pilose.

A widespread species but uncommon in our region. To be expected in Izabal and in Mexico.

Ipomoea sagittata Lam. Ill. 1: 466. 1791.

In swamps, $300 \mathrm{~m}$.; Huehuetenango (Cienaga de Lagartero, Steyermark 51539). British Honduras (Pueblo Nuevo, New River). Southeastern United States; Mexico; West Indies. 
Usually a small, herbaceous vine, the stems very slender, glabrous throughout or nearly so; leaves slender-petiolate, 4-7 cm. long, very deeply hastate at the base, entire, the terminal lobe almost linear, the basal lobes linear or lanceolate, often almost as long as the terminal one; inflorescence 1.flowered, peduncles stout, shorter than the petioles, the pedicels elongate, thick and dilated above; sepals oval, $8-9 \mathrm{~mm}$. long, glabrous, subcoriaceous, obtuse or rounded at the apex and mucronulate; corolla purple, glabrous, about 6-7 $\mathrm{cm}$. long, the limb $6 \mathrm{~cm}$. broad or larger.

Known in Guatemala from a single collection. The species reaches its southern limit here, in continental North America.

Ipomoea santae-rosae Standl. \& Steyerm. Field Mus. Bot. 23: 81. 1944. Campanilla; campana.

Moist or wet thickets or dry, brushy slopes, $300-1,400$ m.; Baja Verapaz; Guatemala; Zacapa; Santa Rosa (type from Chiquimulilla, Standley 79211); Quezaltenango; Huehuetenango. El Salvador; Honduras; Nicaragua. Mexico (Chiapas).

A slender woody vine, glabrous throughout or nearly so; leaves long petiolate, broadly ovate-cordate, $4-10 \mathrm{~cm}$. long, $3.5-6.5 \mathrm{~cm}$. broad, long-acuminate, deeply cordate at the base, hirtellous beneath at the base of the blade, otherwise glabrous; inflorescence a 1-3 flowered cyme, the peduncles mostly about $1 \mathrm{~cm}$. long, the pedicels slender and thickened upward; sepals subequal, subcoriaceous, $18-30 \mathrm{~mm}$. long, oblong to oval, obtuse and short-aristate at the apex, somewhat thickened and venose in fruit; corolla campanulate, red-purple or rose-pink, $6.5-9 \mathrm{~cm}$. long, glabrous, the tube $1.5 \mathrm{~cm}$. or broader at the mouth; capsule 4-celled, subglobose, glabrous, 8-12 mm. long; seeds 4 , fuscous, minutely puberulent.

The large sepals make this one of the most distinctive species of Ipomoea in Central America.

Ipomoea saxorum Standl. \& Steyerm. Field Mus. Bot. 23: 81. 1941. Quiebra cajete.

In thickets or woods, $150-1,000 \mathrm{~m}$., endemic; Chiquimula (type Steyermark 30254); Huehuetenango; Santa Rosa.

A herbaceous vine, the stems rather stout, densely reflexed or spreading pilose; leaves rounded-ovate, $5-8 \mathrm{~cm}$. long, 5-7 cm. broad, obtuse or acute, truncate or subcordate at the base, densely hirtellous or short-pilose on both surfaces, petioles shorter than the blades, 1-3.5 cm. long; inflorescence 1-few-flowered cymes, peduncles stout, 4-10 cm. long, densely spreading pilose, the stout pedicels $1.5-2.5$ $\mathrm{cm}$. long, pilose; sepals unequal, coriaceous, rounded at the apex, the outer ones oval, $5 \mathrm{~mm}$. long, sparsely hirtellous near the apex, the inner ones glabrous, broader, $8 \mathrm{~mm}$. long; corolla white, glabrous, 6-7 cm. long, the tube $1 \mathrm{~cm}$. broad in the throat; capsule subglobose, glabrous, $1 \mathrm{~cm}$. long, broadly rounded at the apex and abruptly contracted into the style; the style thickened at the base and with a thickened subrotate point of dehiscence about $2 \mathrm{~mm}$. above the capsule; seeds glabrous. 
Ipomoea seducta House, Ann. N. Y. Acad. Sci. 18: 241. 1908.

Damp thickets and forest edges, 250-1,900 m.; Alta Verapaz (type, Tuerckheim 7926); Huehuetenango. Mexico (Chiapas).

Twining herbaceous vines with slender glabrous stems. Leaves suborbicularovate, acuminate, cordate, $5-10 \mathrm{~cm}$. long and $3-7 \mathrm{~cm}$. broad, glabrous, the petioles $1-1.5 \mathrm{~cm}$. long, borne with the peduncle on a "short-shoot" about $1 \mathrm{~mm}$. long, the petioles of sterile leaves of ten much longer; inflorescence two or three-flowered with only one flower developing, peduncles mostly less than $2 \mathrm{~cm}$. long, the pedicels less than $1 \mathrm{~cm}$. long; sepals unequal, all apiculate, the outer ones broadly lanceolate, 4-6 mm. long, the inner ones $8-10 \mathrm{~mm}$. long; corolla subcampanulate or funnelform, $5-7.5 \mathrm{~cm}$. long, expanded from the base and about $1 \mathrm{~cm}$. broad at the throat, stamens reaching to the throat but not exserted, limb $4-5 \mathrm{~cm}$. broad, style elongated and filiform.

This species is related to $I$. purga but is distinguished by the subcampanulate corolla and the leaves and associated peduncle being borne on a "short-shoot," which is the fused bases of the petiole and peduncle. The ecology of the two species seems to be quite different in Guatemala.

The shortening of petioles at fertile nodes is of interest and occurs in several other species of related morning-glories, including I. purga.

Ipomoea sepacuitensis Donn.-Sm. Bot. Gaz. 56: 59. 1913. Ixcajen (Quecchí).

Probably to be found in thickets and in edges of clearings; Alta Verapaz (type from Finca Sepacuite, Cook \& Griggs 590). British Honduras.

Twining herb with herbaceous or suffrutescent stems, these with coarse setose pubescence or glabrous with age. Leaves trilobate, the lobes to near the middle or less, glabrous, with 7-9 nerves from near the base, the base cordate, the petioles glabrous or sparsely setose, to about $10 \mathrm{~cm}$. long, the blade $10-17 \mathrm{~cm}$. long and about as broad; peduncles coarse, setose or not, to about $15 \mathrm{~cm}$. long; inflorescence cymose, few-flowered; flowers white with rose within; calyx fleshy, glabrous, the lobes very unequal in size, the outer ones broadly ovate and obtuse, 10-20 $\mathrm{mm}$. long, the inner one similar and 15-35 mm. long; corolla campanulate, about $5 \mathrm{~cm}$. long or perhaps more; capsule coriaceous, glabrous, to $25 \mathrm{~mm}$. long or perhaps larger at maturity.

Known from only four collections, two of these distributed as different species of Calonyction.

Ipomoea sessilis L. Wms. Fieldiana, Bot. 32: 195. 1970.

Probably to be found in thickets as are most Ipomoeas, known only from the type, between Nentón and Miramar, Huehuetenango, Steyermark 51566. Endemic. 
Delicate twining herbs with glabrous stems to $1 \mathrm{~mm}$. in diameter. Leaves broadly ovate-cordate, shortly acuminate, sparsely setose pubescent on both surfaces and ciliate, the blades $2-4 \mathrm{~cm}$. long and about as broad, the petioles slender, sparsely setose, shorter than the blades, $1.5-3 \mathrm{~cm}$. long: inflorescences of a single flower borne in the axiles of leaves, peduncle none or very short, the pedicel fleshy, obscurely aculeolate and ridged (at least in dry material), up to about $0.8 \mathrm{~cm}$. long; sepals chartaceous to somewhat carnose, verrucose ridged at the base, narrowly lanceolate, acuminate and subaristate, $1.5-2 \mathrm{~cm}$. long, the outer two slightly longer than the inner three; corolla rose-pink with white at base and in middle of lobes, narrowly campanulate, about 5-6 $\mathrm{cm}$. long, glabrous outside; capsule unknown.

The species is easily distinguished from the other species known in Guatemala by the combination of long sepals which are relatively narrow and the sessile one-flowered inflorescences.

Ipomoea setifera Poir. in Lam. Encycl. Meth. 6: 17. 1804; O'Donell, Lilloa 39: 237, fig. 1959. Convolvulus ruber Vahl, Eclog. 2: 12. 1798. I. rubra Millsp. Field Mus. Bot. 2: 86. 1900, non. I. rubra Murr. 1791. I. calidicola Standl. \& L. Wms. Ceiba 3: 127. 1952; I. serrulifera Standl. \& L. Wms. l.c. 128.

Thickets and open forests at or near sea level; Izabal (Tuerckheim II. 1128). British Honduras (Schipp 495). Nicaragua; South American; tropical Africa.

A rather coarse, herbaceous vine, the stems short-hirsute, the other parts of the plant glabrous; stems and petioles usually minutely aculeolate with short fleshy protuberances; leaves long-petiolate, about 7-14 cm. long, varying from broadly ovate-cordate to triangular-hastate, acute or obtuse, the basal lobes obtuse or acute; inflorescence 1-5-flowered, foliaceous bracts at the bases of the pedicels, peduncles generally much longer than the petioles, sometimes $20 \mathrm{~cm}$. long, the pedicels $1.5-2 \mathrm{~cm}$. long; sepals unequal, glabrous, the three outer ones broadly ovate, $15 \mathrm{~mm}$. long, obtuse or subacute, mucronate, the two inner sepals $12 \mathrm{~mm}$. long, ovate-lanceolate, acute or acuminate; corolla rose-pink, $7 \mathrm{~cm}$. long, glabrous; ovary glabrous, 2-celled.

Ipomoea setosa Ker, Bot. Reg. 4: $t$. 335. 1818. I. melanotricha Brandegee, Univ. Cal. Publ. Bot. 4: 381. 1913.

Wet thickets and forest edges, $400 \mathrm{~m}$. or less; Izabal; Santa Rosa. Mexico; British Honduras; Honduras; Nicaragua. South America.

A large, coarse herbaceous vine, the stout stems and petioles hirsute or setose with stout, somewhat fleshy trichomes; leaves large and broad, 10-20 cm. long, deeply 3-7-lobate, cordate at the base, the lobes ovate or lanceolate, long-acuminate; peduncles as long as the petioles or sometimes much longer, 3-12-flowered; pedicels $2.5-3 \mathrm{~cm}$. long, thick and fleshy, setose; sepals oblong, obtuse, subcoriaceous, setose, 10-14 mm. long, enlarged in fruit; corolla pink or purple, 5-6 cm. long; capsule 4-celled, 1.5-2 cm. long, 4-celled, 4-seeded; seeds silky pilose. 
The type, from which the illustration cited was prepared, was grown in England from Brazilian seeds. While O'Donell (Lilloa 29: 241. 1959) does not give Central America in the range of the species it does seem to match the illustration very well.

\section{Ipomoea signata House, Muhlenbergia 3: 46. 1907.}

Thickets and forest clearings, $1,500-2,000 \mathrm{~m}$., in the highlands; Quezaltenango; Huehuetenango (type, Nelson 3595); Sacatepéquez; Sololá; Chimaltenango; Zacapa; El Progreso. Mexico.

Perennial, branched twining vines, the stems mostly $2-3 \mathrm{~mm}$. in diameter, glabrous or sparsely pubescent, the internodes $6-10 \mathrm{~cm}$. long. Leaves ovate, cordate, acuminate, secondary nerves $6-8$ pairs and with tertiary nerves connecting them, the blades $6-14 \mathrm{~cm}$. long and $4-8 \mathrm{~cm}$. broad at maturity, sparsely pubescent on both sides or glabrate, petioles slender, shorter than the blades; inflorescence 1-few-flowered cymes, the peduncles mostly $5-10 \mathrm{~cm}$. long but some to $20 \mathrm{~cm}$. long, pedicels mostly $2-3 \mathrm{~cm}$. long; calyx mostly about $1 \mathrm{~cm}$. long, the outer lobes lanceovate, apiculate, deep green with spathulate margins, the inner lobes similar but longer; corolla salverform, glabrous outside, the tube $4-6 \mathrm{~cm}$. long and $0.5-0.7 \mathrm{~cm}$. in diameter, the limb spreading and $3-4 \mathrm{~cm}$. broad, stamens reaching the throat or exserted, the anthers linear-oblong and $4-5 \mathrm{~mm}$. long, pollen grains spinulose, globose, about $0.1 \mathrm{~mm}$. in diameter; capsules and seeds unknown.

Ipomoea signata has been mostly included in $I$. morelii, quite a different species and one that is quite rare in Guatemala. This species is outstanding among the Guatemalan Ipomoeas in having a salverform corolla with the stamens exserted or at least reaching the throat. The species is not uncommon in the highlands.

Ipomoea silvicola House, Bot. Gaz. 43: 411. 1907. Quiebracajete; campanilla; nechaó (Huehuetenango).

Moist or wet thickets or thin mixed forest, 600-2,000 m.; Chiquimula; Jalapa; Santa Rosa (type from Río de las Cañas, Heyde \& Lux 4022); Escuintla; Chimaltenango; Guatemala; Sololá; Suchitepéquez; Huehuetenango; San Marcos. Southern Mexico; Honduras.

A large or small herbaceous vine, the stems thinly hirsutulous; leaves thin, long-petiolate, orbicular-cordate, abruptly acuminate, entire or of ten trilobate, 5-13 cm. long, appressed-pilose above, more densely so beneath; inflorescence usually 1-3-flowered, peduncles shorter or longer than the petioles, the pedicels usually long and slender, short-hirsute; sepals subequal, lanceolate, herbaceous, acuminate, $2-3 \mathrm{~cm}$. long, pubescent and densely covered with long spreading green spine-like tubercles; corolla bright purple, glabrous, 6-7 cm. long, the limb very broad.

House reports the species from Panama on the basis of a collection made in July, 1860, by Sutton Hayes. A specimen of presumably the 
same collection in the Herbarium of Field Museum is labeled as collected in woods along the road from Escuintla to Antigua, Guatemala. So far as we know, the species has not been found in Panama.

Ipomoea squamosa Choisy in DC. Prodr. 9: 376. 1845. I. morelii Duchass. \& Walp. Linnaea 23: 752. 1850. I. callida House, Muhlenbergia 3: 42, t. 3. 1907. I. wilsonii House, l.c. 44, t. 1. I. vestalii Standl. Contr. Arn. Arb. 5: 130, t. 1\%. 1933.

From swampy thickets and forest edges at sea level to mountain forests and thickets at 2,100 meters. Izabal; Escuintla; Quezaltenango; Solola; Sacatepéquez; Chimaltenango; Guatemala; Jutiapa; perhaps other departments. Mexico through all of Central America and Panama to South America.

Twining herbaceous or suffrutescent vines. Leaves triangular in outline, sagittate, or ovate-cordate, long-acuminate, the lateral lobes spreading, somewhat acuminate; the sinus broad, $6-12 \mathrm{~cm}$. long and $3-8 \mathrm{~cm}$. broad at the base, glabrous to sparsely or densely sericeous-pilose pubescent on both surfaces, petioles slender, pilose or glabrous; inflorescence usually longer than the subtending leaves, a rather compact few-10-flowered cyme, peduncles to $10 \mathrm{~cm}$. long, pedicels bracteate, slender, ultimate segment to $1 \mathrm{~cm}$. long; sepals coriaceous, unequal, ovate to suborbicular, apex rounded or truncate, scarious marginate, glabrous, the outer ones about $5 \mathrm{~mm}$. long, the inner ones to about $1 \mathrm{~cm}$. long; corolla infudibuliform, glabrous, pink to purple, (4)-7-8 cm. long, stamens inserted near the base of the corolla and only about $2 \mathrm{~cm}$. long.

We have followed Dr. O'Donell in using I. squamosa for this common, perhaps aggregate, Ipomoea. The several synonyms given above, all of which have been applied to Guatemalan material, are ones which he has indicated to belong here.

Ipomoea steerei (Standl.) L. Wms. Fieldiana, Bot. 32: 195. 1970 Exogonium steerei Standl. Carnegie Inst. Wash. Publ. 461: 83. 1935.

Known in Guatemala only from thickets in the vicinity of Tikal, Petén. Mexico.

Twining herbaceous or suffrutescent vines with rather coarse stems up to $3-$ $4 \mathrm{~mm}$. in diameter, densely sericeous-puberulent, becoming glabrous, the internodes 6-15 cm. long. Leaves elliptic to elliptic-ovate, obtuse, somewhat cuneate at the base, mostly with 4-6 lateral nerves, the lower surface densely sericeouspubescent with appressed hairs and the papillate excrescences with clumps of pubescence, the upper surface appearing green but sparsely appressed sericeouspubescent, the petioles short, sericeous pubescent, $0.8-1.5 \mathrm{~cm}$. long; inflorescences axillary, a (one-) few-many-flowered dichasium either shorter or longer than the subtending leaf, up to about $20 \mathrm{~cm}$. long but usually less, the peduncle $1-6 \mathrm{~cm}$. long, puberulent, the pedicels mostly about $2 \mathrm{~cm}$. long, thickened at the apex; calyx coriaceous, about $1 \mathrm{~cm}$. long at anthesis and in fruit, glabrous, the lobes unequal, the outer ones suborbicular or ovate, apex rounded, 5-8 $\mathrm{mm}$. long, the inner 


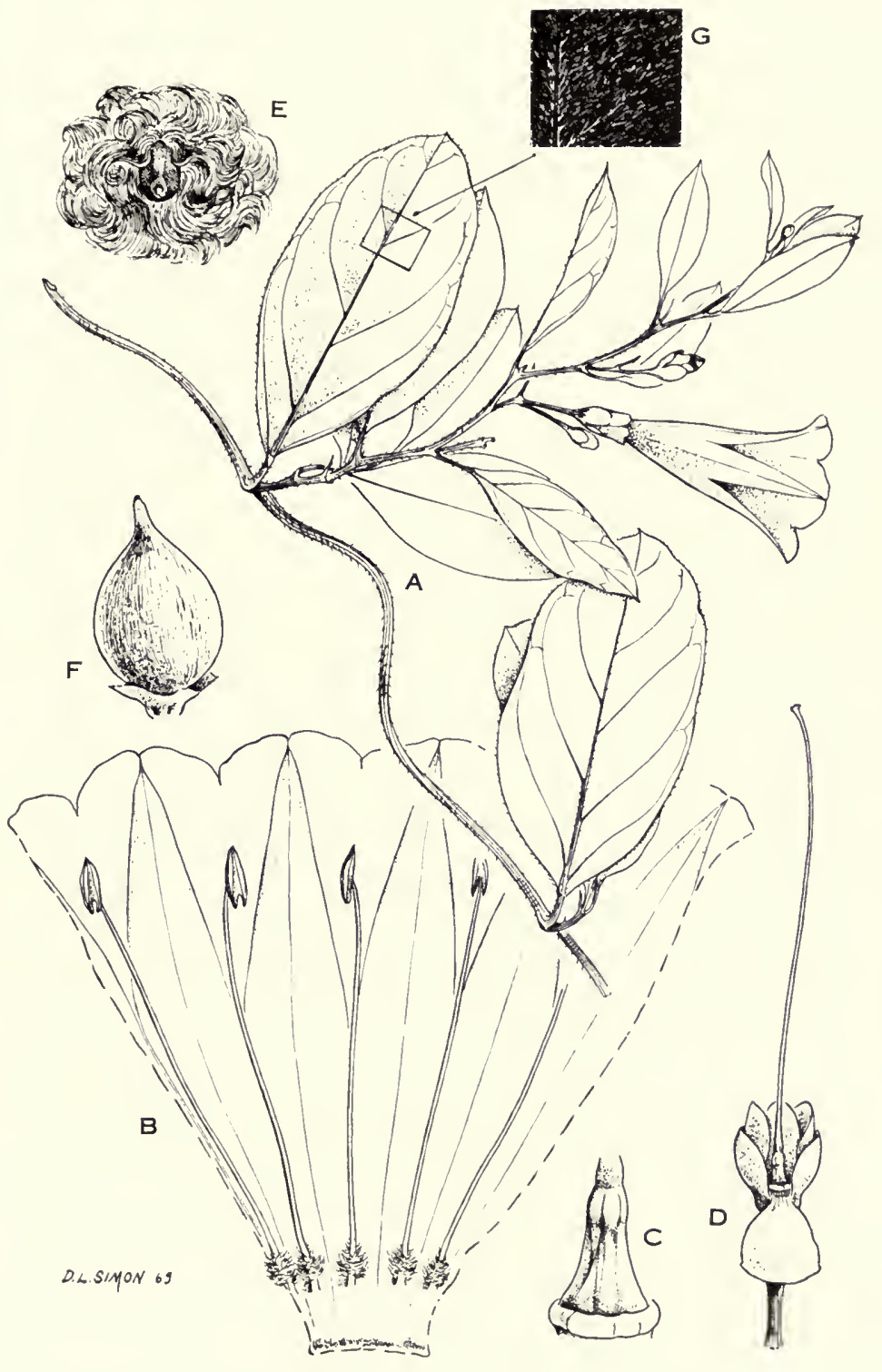

FIG. 6. Ipomoea steerei. A, habit of plant, $\times 1 / 2 ; \mathrm{B}$, corolla dissected to show anthers, $\times 1$; , ovary showing disc below and constriction at base of style, $\times 5$; D, calyx and pistil, $\times 1$; E, seed with dense coma, $\times 11 / 2 ; \mathrm{F}$, mature capsule, $\times 11 / 2 ; G$, under surface of leaf enlarged to show dense sericeous pubescence. 
ones suborbicular or ovate, obtuse or retuse, cochleate, about $10 \mathrm{~mm}$. long; corolla red or carmine, narrowly campanulate, glabrous outside, 5-6 cm. long, the lobes shallow and rounded, stamens inserted near the base of the corolla and reaching nearly to the apex, the filaments bearded at the base; pistil glabrous, on a glandular disc, the style about $5.5 \mathrm{~cm}$. long, contracted and deciduous just above the ovary; capsule broadly ovoid, with thickened persistent base of the style, the whole about $1.5 \mathrm{~cm}$. long; seeds black, about $5 \mathrm{~mm}$. long with very abundant coma of crisped hairs attached on the back and near the apex.

The only species in Guatemala with sericeous leaves with obtuse or cuneate bases and red or carmine flowers.

Ipomoea stolonifera (Cyrill.) Gmel. Syst. Vog. 1: 345. 1796. Convolvulus littoralis L. Syst. ed. 10.924. 1759, not Ipomoea littoralis Blume, 1826. C. stoloniferus Cyrill. Pl. Rar. Neap. 1: 14. 1788. I. littoralis Boiss. Fl. Orient. 4: 112. 1879.

Sandy seashores; Izabal. Southeastern United States; Mexico; British Honduras to Panama; West Indies; South America; Old World tropics.

Plants prostrate and creeping, succulent, glabrous; leaves long-petiolate, mostly oblong or oval, rounded at the base, rounded or emarginate at the apex, $3-7 \mathrm{~cm}$. long, the blades sometimes shallowly or deeply 3-5-lobate; peduncles short, usually 1-flowered; sepals equal or the outer ones shorter, oblong, obtuse, mucronulate, subcoriaceous, glabrous, 10-15 mm. long; corolla glabrous, 4-5 cm. long, white with a purple throat; ovary glabrous, 4-celled; capsule globose, 1-1.5 cm. long, with 4 or fewer seeds, these tomentose.

A characteristic member of the seashore vegetation of the Atlantic coast of Central America, but seldom occurring in abundance.

Ipomoea suffulta (HBK.) G. Don, Gen. Syst. 4: 276. 1838. Convolulus suffultus HBK. Gen. \& Sp. Pl. 3: 102, t. 211. 1819.

Trailing over rocks, 800-1,200 m.; Huehuetenango. Southern Mexico.

Small herbaceous vines, the stems sparsely short hirsute pubescent; leaves or leaf-like bracts pilose on both surfaces with slender bulbose-based hairs, borne on peduncles or "short shoots" 1-4 cm. long (and without buds in the axil on the main stem), rounded-cordate or reniform-cordate, $2-5 \mathrm{~cm}$. long and as broad or broader than long, sessile on the peduncles and with usually a single flower borne in the axil of the leaf or leaf-like bract; inflorescence 1-(2-) flowered and except the corolla often hidden in the conduplicate bract; calyx 5-6 mm. long, the sepals unequal, the outer ones elliptic-oval, the inner ones oblong, obtuse, apiculate, glabrous; corolla funnelform, 6-8 cm. long, glabrous outside, pink to purple.

A most unusual species in which the leaves or leaf-like bracts are borne on peduncles or "short shoots." These are sessile or nearly so and with usually a single nearly sessile flower in the axil. A single collection is known from Guatemala. 

1970.

Ipomoea teruae Molina \& Williams, Fieldiana, Bot. 32: 196.

Vine climbing over trees, alt. 2,000 m.; Sololá (type Williams, Molina \& Williams 25331). Endemic.

Large twining herbaceous vines, the puberulent stems to $4 \mathrm{~mm}$. or more in diameter. Leaves suborbicular-ovate, cordate, the apex acute or short acuminate, the blade $4-7 \mathrm{~cm}$. long and as broad, densely sericeous-pubescent below, glabrous or nearly so above, petioles $1.5-4 \mathrm{~cm}$. long, pubescent; inflorescence about as long as or longer than the subtending leaves, dichasioid, few-flowered, peduncle stout, 5-8 cm. long, pedicels $1.5-2 \mathrm{~cm}$. long, stout, puberulent; calyx glabrous, about $1 \mathrm{~cm}$. long, the lobes broadly ovate to suborbicular, apex obtuse or rounded, the outer ones only slightly shorter, cochleate, coriaceous, the margins chartaceous; corolla lilac, $4-5 \mathrm{~cm}$. long, campanulate, glabrous outside, the stamens reaching to about the middle; capsule and seeds unknown.

This attractive species may be distinguished from all those known in Guatemala by the sericeous undersurface of the leaves, the subequal, broad and cochleate calyx lobes.

Ipomoea tiliacea (Willd.) Choisy in DC. Prodr. 9: 375. 1845. Convolvulus tiliaceus Willd. Enum. Pl. 1: 203. 1809. C. fastigiatus Roxb. Hort. Beng. 13. 1814. I. fastigiata Sweet, Hort. Brit. 288. 1826. Quilamul.

Moist or dry thickets, often on rocky hillsides or in hedges, frequent in waste places or a weed in cultivated grounds, $1,800 \mathrm{~m}$. or less; Petén; Chiquimula; Santa Rosa; Escuintla; Guatemala; Suchitepéquez; Retalhuleu; San Marcos; Quezaltenango. Southern Florida; Mexico; British Honduras to El Salvador and Panama; West Indies; South America.

A large or small, herbaceous vine, glabrous or sparsely pubescent; leaves longpetiolate, cordate-ovate or rounded-cordate, $5-8 \mathrm{~cm}$. long, acute, entire or trilobate; inflorescences few-several-flowered cymes, peduncles equaling the petioles or of ten much longer, the pedicels mostly short; sepals subcoriaceous, oblong to ovate, mucronate or aristulate, unequal, the larger ones about $8 \mathrm{~mm}$. long; corolla purple, pink, or rarely white, usually with a dark throat, $3-5 \mathrm{~cm}$. long, glabrous; capsule subglobose, 2-celled, 8-10 $\mathrm{mm}$. in diameter; seeds glabrous.

Known in El Salvador as "campanola" and "manto de Jesús"; "hebil" (Yucatan, Maya). One of the common weedy species of the Central American lowlands.

Ipomoea tricolor Cav. Icon. 3: 5, t. 208. 1794. Campanilla; quiebra-cajete.

Moist thickets, sometimes in hedges or waste ground, occasionally planted for ornament, 800-1,850 m.; Jalapa; Jutiapa; Santa Rosa; 
Guatemala; Chimaltenango. Mexico to Costa Rica; West Indies; South America.

A small or large, herbaceous vine, glabrous throughout; leaves long-petiolate, rounded-cordate, thin, entire or obscurely lobate, abruptly acuminate or obtuse; peduncles stout, hollow, $2-5 \mathrm{~cm}$. long, usually several-flowered, the stout pedicels 5-40 mm. long; sepals oblong-lanceolate, obtuse, white-marginate, $6-7 \mathrm{~mm}$. long; corolla blue with a white throat, 5-6 $\mathrm{cm}$. long; the limb $6-8 \mathrm{~cm}$. broad; capsule globose-ovoid, 1-1.5 cm. long, glabrous; seeds glabrous.

The Maya name of Yucatan is reported as "yaxcelil." This species has been reported from Guatemala under the name I. violacea L. The blue flowers are very handsome. Possibly an escape from cultivation in many places.

Ipomoea trifida (HBK.) G. Don, Gen. Syst. 4: 280. 1838; O’Donell, Lilloa 30: 58. 1960. Convolvulus trifidus HBK. Nov. Gen. \& Sp. Pl. 3: 107. 1819. Campanilla; campana; cajetilla; sisicuch (Cobán, Quecchí).

Moist or wet thickets or hedges, in waste place or in fields, 2,500 m. or less; Petén; Alta Verapaz; Izabal; Jutiapa; Zacapa; Jalapa; Santa Rosa; Escuintla; Guatemala; Sacatepéquez; Suchitepéquez; Retalhuleu; Quezaltenango; San Marcos; doubtless in all departments. Southern United States; Mexico and British Honduras to South America.

Small to of ten large much branched vines, the stems rounded or angled, 1-3 $\mathrm{mm}$. in diameter, pubscent or usually glabrous. Leaves cordate with the blade ovate, the margins undulate, sometimes to trilobate or rarely 5 -lobate, $2-10 \mathrm{~cm}$. long, the mid-lobe ovate to lanceolate, the sinus deep or shallow, mostly glabrous (ours) to densely pubescent, the petioles slender, about as long as the blades; inflorescence cymose, few-(1-) many-flowered, the peduncles $2-25 \mathrm{~cm}$. long, pedicels 3-15 mm. long; sepals coriaceous or straw-like, the outer ones elliptic to ovate, obtuse or usually long acuminate, glabrous or sparsely pubescent, $4-10 \mathrm{~mm}$. long and half as broad, the inner sepals elliptic to ovate, acuminate and often cuspidate, glabrous or sparsely pubescent, $5 \mathbf{- 1 2} \mathrm{mm}$. long and half as broad; corolla infundibuliform, glabrous, $2-4 \mathrm{~cm}$. long; anthers reaching to about the middle of the corolla; capsule subglobose, glabrous or sparsely pubescent, $5-7 \mathrm{~mm}$. long.

A common and widely distributed species needing study. Perhaps more than one species is included here.

Ipomoea triloba L. Sp. Pl. 161. 1753. I. confertiflora Standl. Carnegie Inst. Wash. Publ. 461: 83. 1935 (type from Río Grande, British Honduras, Schipp 1236). Campanilla; quilamul; resicuch (Cobán, Quecchí). 
Moist or wet thickets or borders of forest, frequently in hedges or a weed in cultivated ground, 1,500 m. or less, most abundant at low elevations; Petén; Alta Verapaz; Zacapa; Chiquimula; Jutiapa; Santa Rosa; Escuintla; Guatemala; Retalhuleu; Sololá; Quezaltenango; Huehuetenango. Southern United States; Mexico; British Honduras; El Salvador to Panama; West Indies; South America to Argentina; naturalized in the Old World tropics.

A small or large, slender, herbaceous vine, sparsely or densely pubescent or glabrate; leaves long-petiolate, small, mostly $3-5 \mathrm{~cm}$. long but of ten larger, cordate at the base, usually deeply 3-5-lobate, the lobes acute or acuminate, entire; inflorescence 1-several-flowered, peduncles mostly longer than the petioles, the pedicles slender, 1-2 cm. long; sepals oblong or oval, 5-6 $\mathrm{mm}$. long, acute or acuminate and of ten mucronate, usually pilose dorsally and long ciliate; corolla pink or pale purple, with a dark red or dark purple throat, glabrous, commonly (1.5-)2.5-3.5 $\mathrm{cm}$. long, the limb 1-2 cm. broad or more; capsule 2-celled, pilose or glabrous, about $7 \mathrm{~mm}$. in diameter; seeds glabrous.

This is perhaps the most abundant Ipomoea species of the Pacific lowlands, where, through much of the year it covers almost completely thousands of acres of thickets. It is not a pretty plant, and is decidedly weedy in nature.

This is the oldest name for an exceedingly abundant and variable group of plants that extend from the southern United States through Mexico, Central America, the West Indies, and South America to Argentina. Ipomoea triloba in the broad sense includes I. trichocarpa Ell. from the southern United States, I. ramonii Choisy from Cuba, I. confertiflora Standl. from British Honduras, and I. trichocarpa var. australis O'Donell from southern South America.

Ipomoea tuxtlensis House, Ann. N. Y. Acad. Sci. 18: 256. 1908. Quiebra-cajete.

Moist or wet thickets, often in rocky places, $450 \mathrm{~m}$. or less; Petén; Alta Verapaz; Izabal. Southern Mexico; British Honduras.

A small or large, herbaceous vine, usually very densely pubescent throughout; leaves long-petiolate, ovate-cordate or rounded-cordate, $5-15 \mathrm{~cm}$. long, deeply cordate to truncate at the base, entire or usually trilobate, the lobes acute or obtuse, densely appressed-pilose above, densely sericeous beneath with lustrous hairs; inflorescence few-many-flowered, peduncles very short, usually less than $2 \mathrm{~cm}$. long, the stout pedicels mostly $4-5 \mathrm{~mm}$. long; sepals subequal, $10-12 \mathrm{~mm}$. long, oblongovate, the outer ones densely sericeous, rounded at the apex, the inner ones glabrous or nearly so, retuse; corolla wine-red, $3.5-6 \mathrm{~cm}$. long, narrowly campanulate, glabrous, the limb $2-3 \mathrm{~cm}$. broad; capsule globose, glabrous, $1 \mathrm{~cm}$. in diameter, densely lanate with very long hairs. 
Ipomoea tyrianthina Lindl. Bot. Reg. 24: Misc. 87. 1838. Pharbitis tyrianthina Hook. Bot. Mag. 49: t. 4024. 1843. P. longipedunculata Mart. \& Gal. Bull. Acad. 12, pt. 2: 271. 1845. I. longipedunculata Hemsl. Biol. Cent. Am. Bot. 2: 389. 1882. Quiebra cajete.

Moist thickets, 1,600-3,800 m. (?); Quiché; Huehuetenango; Chimaltenango. Mexico; Honduras.

A small or large, herbaceous vine, the stems sparsely reflexed-hirsute or glabrate; leaves long-petiolate, orbicular-ovate, $6-10 \mathrm{~cm}$. long, abruptly acuminate, cordate at the base, entire or rarely trilobate, thinly hirtellous or short-pilose; inflorescence 1-5-flowered, peduncles long and slender, of ten much longer than the leaves, the pedicels 1-4 cm. long; sepals subequal, oblong-lanceolate, the outer ones acute or rarely obtuse, the inner acute, $12-15 \mathrm{~mm}$. long, long pilose pubescent becoming glabrate above, the hairs usually from thickened bases, or the inner sepals quite glabrous; corolla rose-purple, $6-8 \mathrm{~cm}$. long, glabrous.

Closely related to Ipomoea purpurea (L.) Roth and perhaps not distinct from it.

Ipomoea villifera House, Muhlenbergia 5: 70. 1909.

Wet thickets and forest, 1,100-1,400 m., endemic; Huehuetenango (type, Nelson 3579; Molina 21404).

Stout, twining vines, the stems muriculate, pilose with brownish hairs, becoming glabrous. Leaves suborbicular, cordate, entire or trilobate, sparsely appressed-pubescent above, more densely so below, the blade 7-12 $\mathrm{cm}$. long and as broad, the petiole slender, pubescent, 5-7 cm. long; inflorescence few-severalflowered, subcapitate, villous, the peduncle at maturity exceeding the subtending leaf, villous, the bracts in the inflorescence ovate to ovate-lanceolate, acute, villous, $1-2.5 \mathrm{~cm}$. long, the pedicels very short; sepals narrowly lanceolate, acuminate, villous, 16-22 $\mathrm{mm}$. long; corolla narrowly campanulate, purple, sparsely villous outside on the tube and plicae.

A rare species from the mountains of Huehuetenango. Known only from the two collections cited above. It is closely related to I. mairetti Choisy.

Ipomoea wallii (Morren) Hemsl. Biol. Cent. Am. Bot. 2: 396. 1882. Batatas wallii Morren, Ann. Soc. Agric. Bot. Gand 2: 285. 1846.

Moist or wet thickets, $300 \mathrm{~m}$. or less; Petén (El Paso, Lundell 1532). British Honduras; Honduras.

A small or large, herbaceous vine, glabrous throughout or nearly so; leaves long-petiolate, cordate-ovate or deltoid-ovate, $6-15 \mathrm{~cm}$. long, acute, rather deeply cordate at the base; inflorescence usually several-flowered, ped uncles usually much longer than the petioles, sometimes short; sepals more or less unequal, subcoriaceous, ovate or oval, $7-8 \mathrm{~mm}$. long, glabrous, rounded at the apex; corolla white, $4.5-6.5 \mathrm{~cm}$. long, glabrous; capsule glabrous, $8 \mathrm{~mm}$. long. 
No authentic material of this species is available, and it is not at all certain that the material we have referred here has been named correctly.

\section{UNRECOGNIZED SPECIES}

IPomoea BReviPes Peter in Engler \& Prantl, Pflanzenfam. IV. Abt. 3a: 30. 1891. Hyponym.

No description of the species has been published, and it is merely listed in a skeleton key prepared by Peter to cover a few species of the genus. The native country is cited as Guatemala. The name, like some others published by Peter at the same time, has no formal status.

Calonyction campanulatum Hallier f., Bull. Herb. Boiss. ser. 1, 5: 1050, t. 18, f. 2. 1897. Ipomoea setosa campanulata House, Ann. N. Y. Acad. Sci. 18: 219. 1908.

The identity of this species is not certain. We presume that of the several specimens cited by Hallier the collection made near Granada, Nicaragua, Lévy 1316, and from which the illustration was made may well be the type although it does not correspond too closely to the description. There are two possibilities,- the species may be a synonym of $I$. setosa as treated in this flora or it may be the same as $I$. sepacuitensis but if transferred to Ipomoea it would become a homonym of $I$. campanulata L.

Convolvulus mollissimus Bertol. Misc. Bot. 20: 11, t. 3. 1859. The type from Volcán de Agua, Velásquez.

We do not know what the species may be and the publication cited is not available to us. We guess that it may be Ipomoea mairetti.

Ipomoea rostrata Peter in Engler \& Prantl, Pflanzenfam. IV. Abt. 3a: 30. 1891, hyponym.

This is said to be based on Guatemalan material. No description of the plant has been published.

IPOMOEA SERICOPHYLla Peter, l.c. 31, hyponym.

Based on material said to have come from Guatemala but no description of the species has been published. Possibly the same as I. tuxtlensis House. 
IPOMOEA TORTUGENSIS Peter, l.c. 31, hyponym.

The name is said to be based on Guatemalan material but the collection is not mentioned and no description has been published to validate the name.

\section{ITZAEA Standley \& Steyermark}

Large woody vines; leaves petiolate, entire, densely sericeous beneath; flowers small, green, in few-many-flowered, compact, short-pedunculate, axillary cymes, these shorter than the petioles, or in fruit sometimes elongate; sepals subequal, suborbicular, rounded or very obtuse at the apex and obscurely apiculate, sericeous outside, glabrous within; corolla campanulate, shallowly 5-lobate, sericeous outside, the lobes induplicate valvate; stamens inserted in the throat of the corolla, short-exserted, the filaments elongate, slightly dilated at the base; anthers oblong, the cells contiguous, the connective narrow; ovary 1-celled, 4-ovulate, pilose; styles 2, short, the stigmas large, globose-capitate; capsule subglobose, somewhat ligneous, the pericarp dry, 3-4-valvate at the apex, finally separating in to numerous longitudinal linear segments suggesting the staves of a barrel; seeds $3-4$, surrounded by bright red pulp, glabrous.

The genus consists of a single species. The generic name is derived from Itzá, name of the race that founded the first Maya Empire.

Itzaea sericea (Standl.) Standl. \& Steyerm. Field Mus. Bot. 23: 83. 1944. Lysiostyles sericea Standl. Field Mus. Bot. 8: 322. 1931.

British Honduras; Petén, to be expected in Izabal; Atlantic coast of Honduras, the type from Lancetilla Valley, Dept. Atlántida.

A large woody vine as much as $15 \mathrm{~m}$. long, the stems densely and minutely sericeous; leaves on slender petioles $1.5-3.5 \mathrm{~cm}$. long, elliptic-oblong or ellipticovate, 7-13 cm. long, $3.5-6.5 \mathrm{~cm}$. broad, obtuse to acuminate, subcordate to acute at the base, glabrous above, very densely lustrous-sericeous beneath; inflorescences solitary, very shortly pedunculate, the pedicels mostly $3-4 \mathrm{~mm}$. long; sepals $4 \mathrm{~mm}$. long; corolla $1 \mathrm{~cm}$. long; capsule subglobose, about $13 \mathrm{~mm}$. in diameter, glabrous.

When fresh, the fruit with its orange-red pulp is strongly suggestive of that of the northern bittersweet (Celastrus scandens).

\section{JACQUEMONTIA Choisy}

Twining herbs, of ten densely pubescent; leaves petiolate, often cordate at the base, entire or sometimes dentate or lobate; inflorescence axillary, umbelliform or head-like cymes, rarely in scorpioid cymes or solitary, flowers small or mediumsized; bracts small and linear or lanceolate or large and leaf like; sepals 5, equal or unequal; corolla funnelform or campanulate, blue, lilac, or white, 5-dentate or almost entire; stamens and style included; style 1, filiform, the 2 stigmas elliptic or oblong and complanate, rarely globose or linear; ovary 2-celled, 4-ovulate; disk 

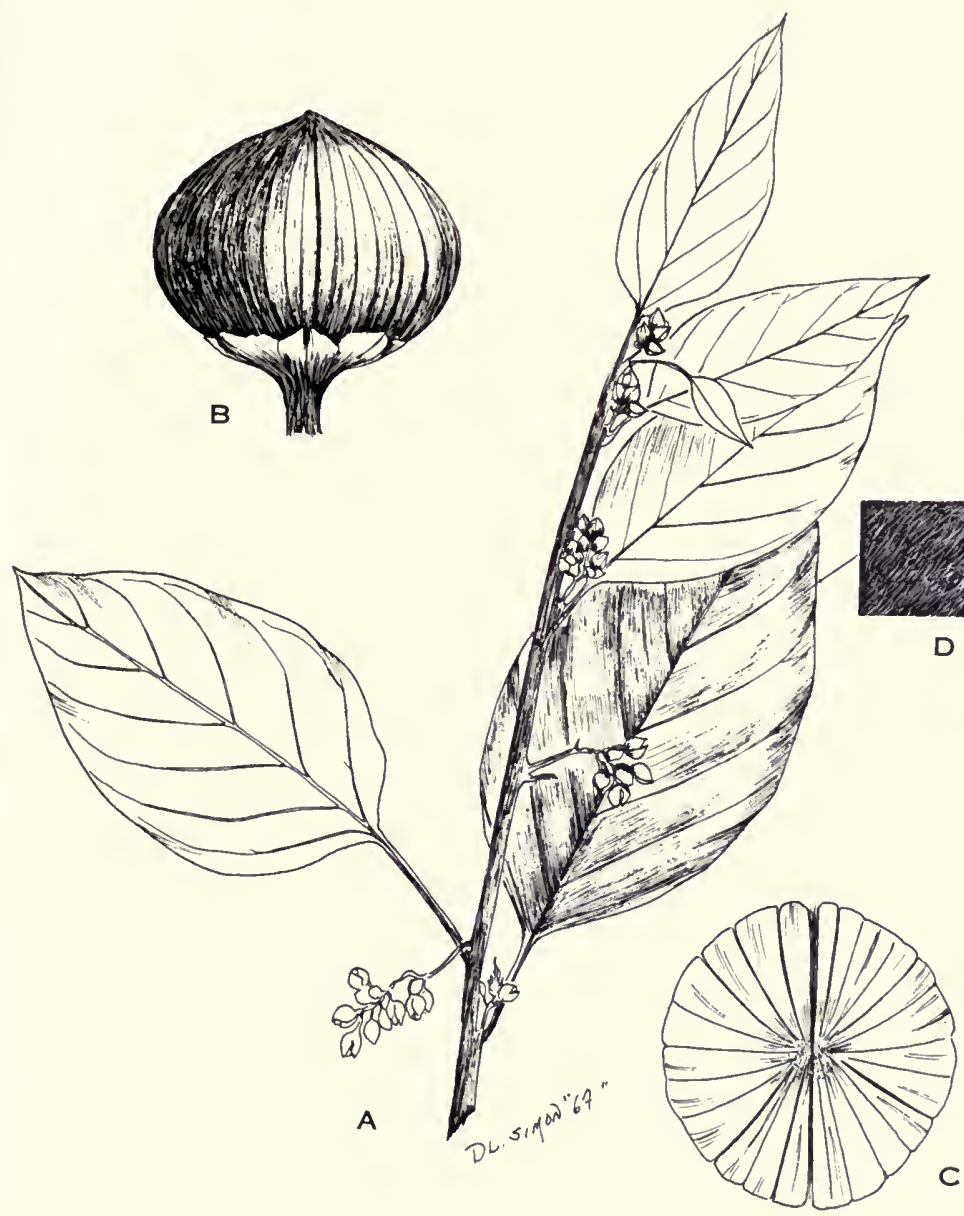

FIG. 7. Itzaea sericea. A, habit, $\times 1 / 2 ; \mathrm{B}$, capsule from the side showing indurated calyx lobes, $\times 2$; C, capsule from above, $\times 4 ; D$, pubescence on upper surface of leaf, much enlarged.

small or none; capsule globose, 2-celled, with 4 valves, 4-seeded; seeds glabrous, tuberculate, or pilose.

About 60 species, in tropical America, Africa, Asia, and Australia. One or two others are known from southern Central America. The genus is very closely allied to Convolvulus.

Inflorescences head-like, the bracts large, foliaceous.

Bracts linear or lanceolate; corolla blue.............. tamnifolia.

Bracts broadly ovate to rounded; corolla white . . . . . . . . . J. hirtiflora. 
Inflorescences cymose, lax and open or rather dense, the bracts small and inconspicuous.

Leaves rounded or very obtuse at the apex, obtuse or rounded at the base, thick and fleshy, glabrous or nearly so.................. havanensis.

Leaves acute or acuminate, usually cordate or subcordate at the base, thin, of ten densely pubescent.

Sepals rounded at the apex, glabrous or nearly so; peduncles much shorter than the cymes; corolla white. . . . . . . . . . . . . . . . nodiflora.

Sepals acute or acuminate, or at least apiculate, of ten densely pubescent; peduncles usually longer than the cymes.

Inflorescence glandular-pilose . . . . . . . . . . . . . .... azurea.

Inflorescence without glandular pubescence.

Sepals mostly $10-15 \mathrm{~mm}$. long; inflorescence lax.........J. mexicana. Sepals all or chiefly $8 \mathrm{~mm}$. long or shorter; inflorescence dense and compact.

Outer bracts ovate.

J. houseana.

Outer bracts subulate or linear-lanceolate.

Leaves green and glabrate beneath............. pentantha.

Leaves densely velutinous-pubescent beneath.

Calyx 3-4 mm. long; leaves acute or subobtuse.....J. pinetorum. Calyx 5-6 mm. long; leaves usually abruptly cuspidate-acuminate.

J. apiculata.

\section{Jacquemontia apiculata House, Muhlenbergia 5: 66. 1909.}

Moist or dry thickets, 900 m. or less; El Progreso; Retalhuleu; Quezaltenango. Mexico; British Honduras.

A herbaceous vine, small or sometimes several meters long, the stems densely pale-tomentose; leaves long-petiolate, broadly ovate or rounded-ovate, $2-5 \mathrm{~cm}$. long and of ten almost as broad, broad at the apex and usually abruptly cuspidateacuminate, shallowly or deeply cordate at the base, densely and finely soft-pubescent above, densely tomentose beneath with whitish or brownish, soft hairs; the inflorescence lax or dense, peduncles $2-8 \mathrm{~cm}$. long, the pedicels short or sometimes 1-2 cm. long, the flowers few or numerous; sepals unequal, the outer ones spatulateobovate, 5-6 mm. long, subacute, pubescent, the inner ones shorter, ovate, acute; corolla blue or white, $2 \mathrm{~cm}$. broad, glabrous.

Jacquemontia azurea (Desr.) Choisy, Mem. Soc. Phys. Hist. Nat. Geneve 6: 476. 1833. Convolvulus azurea Desr. in Lam. Encycl. 3: 554. 1789. J. guatemalensis Standl. \& Steyerm. Field Mus. Bot. 23: 84. 1944 (type from Chiquimula, Steyermark 30066).

Grassy or brushy plains or hillsides, often in rocky places or in pine forest, 200-1,500 m.; Alta Verapaz; Zacapa; Chiquimula; Jutiapa; Huehuetenango. Southern Mexico; British Honduras; Honduras; Costa Rica; Panama; South America.

A slender annual vine, the stems herbaceous, pilose with rather long, soft, more or less spreading hairs; leaves long-petiolate, ovate-oblong to broadly ovate, 1-5 $\mathrm{cm}$. long, acute to long-acuminate, shallowly cordate or truncate at the base, thinly or densely pilose with long spreading di-or tribrachiate hairs, especially beneath; 
peduncles about 3-flowered, very slender, of ten much longer than the leaves, the pedicels usually much longer than the calyx, glandular-pilose; sepals lanceolate, 3-5 mm. long, pilose with long spreading gland-tipped hairs; corolla usually blue, 6-10 mm. long, glabrous; capsule globose, glabrous, 4-5 mm. long.

When well developed, the plant is elongate and twining. If stunted, it sometimes is procumbent or even erect.

Jacquemontia havanensis (Jacq.) Urban, Symb. Antill. 3: 342. 1902. Convolvulus havenensis Jacq. Obs. Bot. 2: 25, t. 45, f. 3. 1767.

Known in our region only from Turneffe Island, British Honduras, growing on coral sand, frequent ben eath coconut palms along the beach, F.E. Egler 42-41. Yucatan Peninsula of Mexico; Cuba.

Plants suffrutescent, trailing or suberect, less than a meter long, the stems puberulent; leaves short-petiolate, succulent, ovate to oblong, 1-4 cm. long, rounded or subemarginate at the apex, rounded or obtuse at the base, minutely puberulent or almost glabrous; inflorescences sometimes 1-flowered but usually in short-pedunculate few-flowered cymes, the peduncles little longer than the petioles, the pedicels longer than the calyx; outer sepals obovate or suborbicular, rounded at the apex, $1.5 \mathrm{~mm}$. long, the inner ones slightly longer; corolla $1 \mathrm{~cm}$. long, white; capsule $3 \mathrm{~mm}$. long, the seeds ovoid, narrowly marginate.

The Maya name of Yucatan is recorded as "extabentuxiu."

Jacquemontia hirtiflora (Mart. \& Gal.) O'Donell, Anal. Inst. Biol. Mex. 12: 81. 1941. Ipomoea hirtiflora Mart. \& Gal. Bull. Acad. Brux. 12, pt. 2: 267. 1845. J. perryana Duchass. \& Walp. Linnaea 23: 751. 1850. I. lactescens Seem. Bot. Voy. Herald 171. 1854. J. platycephala Donn.-Sm. Bot. Gaz. 57: 423. 1914 (type from Cubilguitz, Alta Verapaz, Tuerckheim 4133).

Moist or wet thickets or open rocky forest, $1,500 \mathrm{~m}$. or lower; Alta Verapaz; Santa Rosa; Huehuetenango. Southern Mexico; British Honduras; Costa Rica; Panama.

A large or small vine, herbaceous, the stems stout, hirsute or glabrous; leaves rounded-ovate to deltoid-ovate, $6-13 \mathrm{~cm}$. long, abruptly short-acuminate or sometimes narrowly long-acuminate, shallowly or deeply cordate at the base, glabrous above or sparsely short-pilose, finely appressed-pilose beneath or glabrate; peduncles of ten much longer than the leaves, stout, the inflorescences capitate or at least head-like, $7 \mathrm{~cm}$. broad or smaller, many-flowered, very dense, the outer bracts about $2 \mathrm{~cm}$. long, orbicular, rounded or very obtuse at the apex, the inner ones almost as broad, densely hirsute; sepals elliptic, acuminate, $12 \mathrm{~mm}$. long; corolla pure white, 3-4 cm. long, villous outside.

When in flower, this is a rather handsome plant, much showier than other Central American species of the genus. Called "mano de gato" in Veracruz. 
Jacquemontia houseana Standl. Field Mus. Bot. 11:140. 1932.

Known only from the El Cayo District of British Honduras, the type collected near El Cayo, H. H. Bartlett 12928.

A herbaceous vine, the stems densely stellate-pilosulous; leaves slenderpetiolate, broadly ovate or ovate-elliptic, $2.5-5 \mathrm{~cm}$. long, abruptly acute or acuminate, shallowly or deeply cordate at the base, softly and densely stellate-tomentulose on both surfaces; cymes dense, many-flowered, head-like, about $2.5 \mathrm{~cm}$. broad, the peduncles as much as $10 \mathrm{~cm}$. long, the flowers sessile, densely crowded; bracts foliaceous, ovate, equaling the sepals; sepals ovate or broadly ovate, $6-8 \mathrm{~mm}$. long, acuminate or long-acuminate, densely tomentulose; corolla blue, glabrous, almost $2 \mathrm{~cm}$. broad.

Jacquemontia mexicana (Loes.) Standl. \& Steyerm. Field Mus. Bot. 23: 84. 1944. Aniseia mexicana Loes. Verh. Bot. Ver. Brandenb. 59: 155.1917.

Brushy hillsides, $400 \mathrm{~m}$.; Santa Rosa (La Morenita, northeast of Chiquimulilla, Standley 78873). Chiapas.

A small slender vine, herbaceous or suffrutescent, the young stems tomentulose, becoming glabrate; leaves thin, on long slender petioles, broadly ovate, $3-11$ cm. long, acuminate, usually abruptly so, shallowly or deeply cordate at the base, thinly stellate-pubescent on both surfaces or glabrate; peduncles slender, about equaling the leaves, lax and few-flowered, the bracts lanceolate, 7-10 $\mathrm{mm}$. long; outer sepals broadly ovate, $10-15 \mathrm{~mm}$. long, acute or acuminate, puberulent, usually subcordate at the base; corolla white, $2-3 \mathrm{~cm}$. long, glabrous.

Jacquemontia nodiflora (Desr.) G. Don, Hist. Dichl. Pl. 4: 283. 1838. Convolvulus nodiflorus Desr. in Lam. Encycl. 3: 557. 1789. Campanilla; chata simpatica; loroquito de monte.

Moist or dry thickets or hedges, often in rocky places, 400-1,500 m.; Petén; Zacapa; Chiquimula; Jalapa; Jutiapa; Santa Rosa; Guatemala; Quiché. Mexico; British Honduras; Honduras; Nicaragua; Costa Rica; West Indies; South America.

A small or rather large, slender vine, herbaceous or suffrutescent below, the stems tomentose or almost glabrous; leaves on slender, short or elongate petioles, oblong-ovate to broadly ovate, $3-5.5 \mathrm{~cm}$. long, acute or acuminate, rounded or shallowly cordate at the base, sparsely tomentulose or glabrate above, usually densely tomentulose beneath, sometimes glabrate in age; cymes many-flowered, dense, short-pedunculate, usually much shorter than the leaves; bracts small and inconspicuous; sepals suborbicular, rounded and muticous at the apex, $2 \mathrm{~mm}$. long, glabrous or nearly so; corolla white, 10-12 mm. long, glabrous; capsule glabrous, globose or ovoid, $4 \mathrm{~mm}$. long.

Recently Lewis and Oliver (Ann. Mo. Bot. Gard. 52: 222. 1965) have stated that this species must be included in Convolvulus based upon a study of pollen. We prefer to leave it in Jacquemontia until 


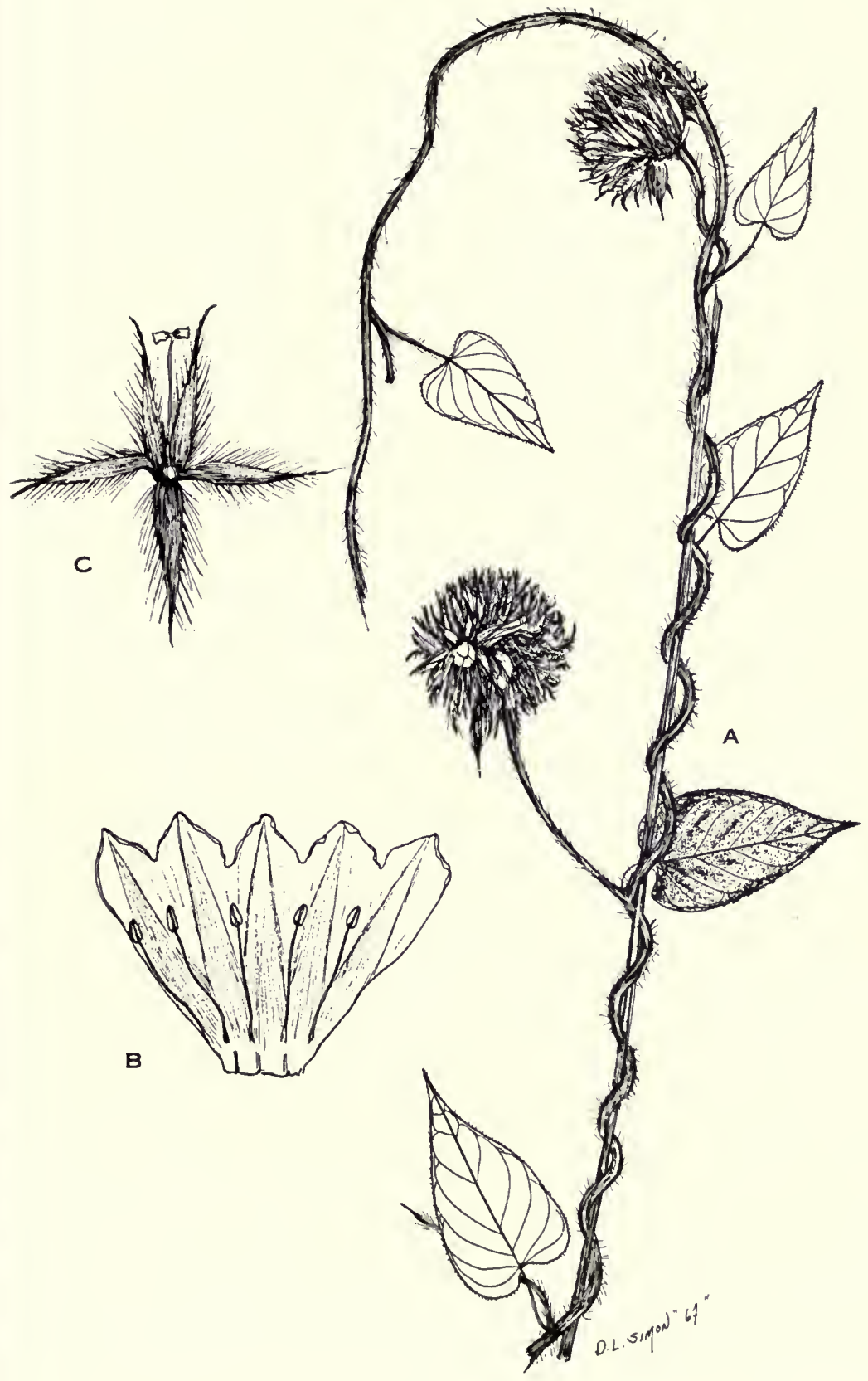

FIG. 8. Jacquemontia tamnifolia. A, habit, $\times 1 / 2 ; \mathrm{B}$, corolla expanded, $\times 2$; C, calyx and pistil, $\times 2$. 
a more thorough study is made of generic characters in this group of Convolvulaceae.

Jacquemontia pentantha (Jacq.) D. Don, Hist. Dichl. Pl. 4: 283. 1838. Convolvulus pentanthus Jacq. Coll. Bot. 4: 210. 1790. J. violacea Choisy, Mem. Soc. Phys. Hist. Nat. Geneve, 61. 1838. J. violacea var. guatemalensis Meissn. in Mart. Fl. Bras. 7: 296. 1869 (type Friedrichsthal 1).

Dry to wet thickets in second growth, 1,500 m. or less; Suchitepéquez; Retalhuleu; Quezaltenango; Huehuetenango. Southern Florida; Mexico; British Honduras; Honduras; Costa Rica; Panama; West Indies; South America.

Usually a small herbaceous vine, the stems pubescent or almost glabrous; leaves slender-petiolate, ovate or broadly ovate, $3-6 \mathrm{~cm}$. long, acute to longacuminate, shallowly or deeply cordate at the base, glabrate, at least in age, somewhat paler beneath; peduncles slender, exceeding the leaves, the cymes dense and almost head-like, few-many-flowered, the bracts small and inconspicuous, the pedicels shorter than the calyx; sepals ovate or lanceolate, acute or acuminate, 4-5 mm. long; corolla blue or white, $2 \mathrm{~cm}$. broad, glabrous; capsule globose, about equaling the sepals.

Maya names of Yucatan are "akilxiu," "sacmiz," "yaax-hebil," and "yaxhal."

Jacquemontia pinetorum Standl. \& Steyerm. Field Mus. Bot. 22: 372. 1940.

\section{Izabal (type Steyermark 38533).}

Plants somewhat woody, prostrate or ascending, branched, the young branches densely velutinous-pilose; leaves long-petiolate, deltoid-ovate, $2-2.5 \mathrm{~cm}$. long, acute or subacuminate, subcordate at the base, grayish, densely stellate, velutinous-pilose on both surfaces; peduncles longer than the leaves, the cymes dense, few-many-flowered, $12 \mathrm{~mm}$. broad, the pedicels short, the bracts small, subulate; sepals $3-3.5 \mathrm{~mm}$. long, densely pilose, rounded-ovate, muticous, rounded at the apex; corolla lavender-purple, $8 \mathrm{~mm}$. long, glabrous.

Jacquemontia tamnifolia (L.) Griseb. Fl. Brit. W. Ind. 474. 1861. Ipomoea tamnifolia L. Sp. Pl. 162. 1753. Thyella tamnifolia Raf. Fl. Tellur. 4: 84. 1836.

Moist or dry thickets, about $900 \mathrm{~m}$; Chiquimula; Jutiapa. Southern United States; Mexico; British Honduras; Honduras; Panama.

A small or large, herbaceous vine, sometimes $6 \mathrm{~m}$. long, hirsute almost throughout, densely so in the inflorescence; leaves slender-petiolate, ovate or broadly ovate, $3-10 \mathrm{~cm}$. long, acute or abruptly acuminate, cordate at the base, 


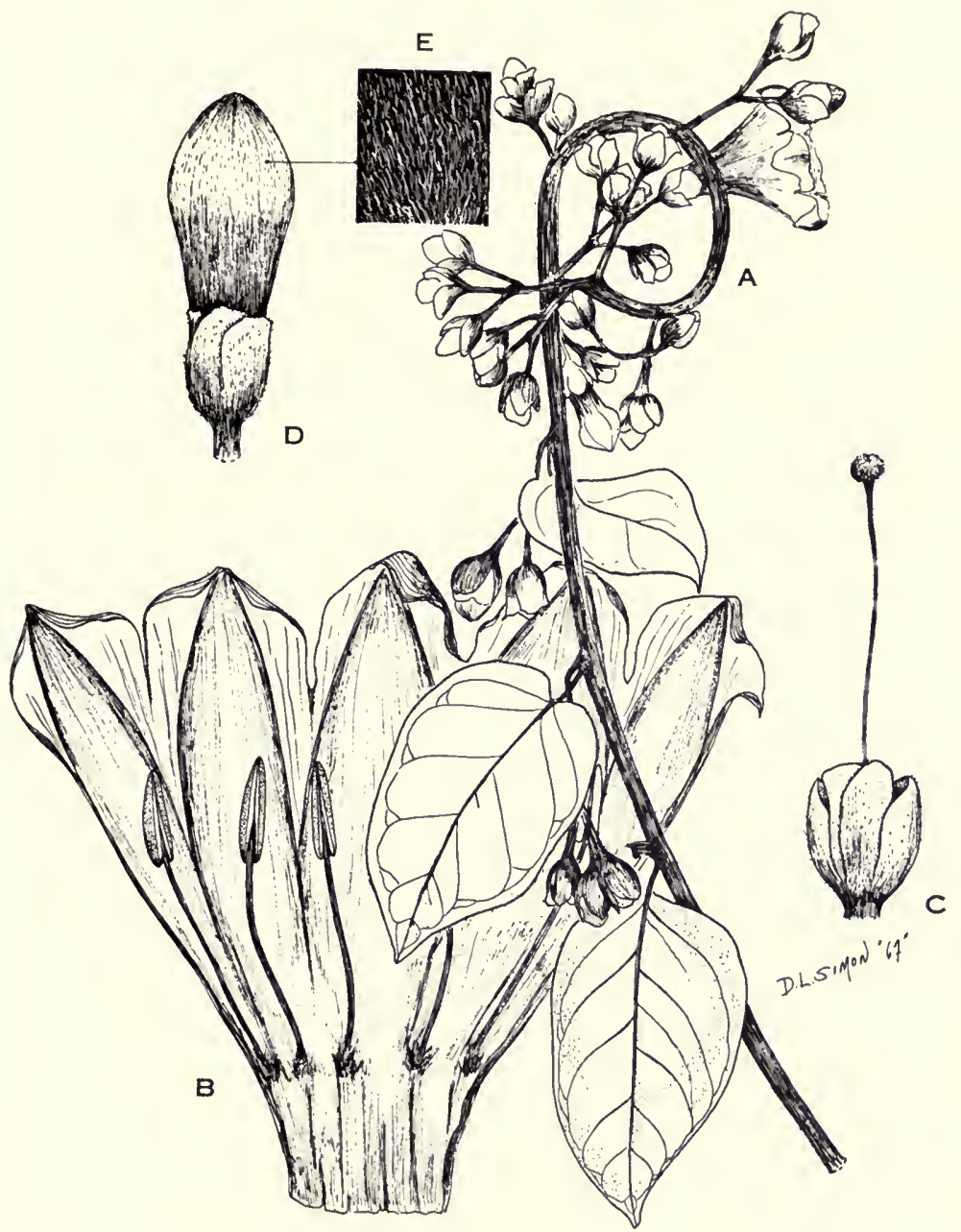

FIG. 9. Maripa nicaraguensis. A, habit, $\times 1 / 2 ; \mathrm{B}$, corolla expanded, $\times 11 / 2$; $\mathrm{C}$, calyx and style, $\times 1 \frac{1}{2} ; \mathrm{D}$, bud, $\times 1 \frac{1}{2} ; \mathrm{E}$, pubescence from the corolla, much enlarged.

sometimes glabrate; peduncles of ten much longer than the leaves, the inflorescence head-like, 3-4 cm. broad, many-flowered, the flowers sessile or nearly so; outermost bracts ovate, 1-3 cm. long; sepals linear, 10-15 mm. long; corolla blue, $1 \mathrm{~cm}$. broad; capsule globose, glabrous, much exceeded by the sepals.

\section{MARIPA Aublet}

Large woody vines, glabrous except in the inflorescence; leaves alternate, coriaceous, petiolate, entire, not cordate; flowers medium-sized or rather small, in 
many-flowered cymes, these usually corymbose or paniculate at the ends of the branches, the bracts scale-like or none; sepals ovate, obtuse, coriaceous, subequal, appressed to the base of the fruit; corolla campanulate, the limb plicate, shallowly 5 -fid; stamens included or exserted, the anthers oblong or linear; disk annular; ovary 2-celled, 4-ovulate; fruit ovoid, oblong, or globose, fleshy or indurate, indehiscent, usually by abortion 1-seeded; séed erect, glabrous.

About ten species, all in tropical America. One other Central American one occurs in Panama.

Maripa nicaraguensis Hemsl. Biol. Cent. Am. Bot. 2: 382. 1882.

Moist or wet forest, 1,000 m. or less; Petén; Alta Verapaz; Izabal. British Honduras, along the Atlantic coast to Costa Rica and South America.

A large woody vine, climbing to a height of $18 \mathrm{~m}$., glabrous or essentially so except in the inflorescence; leaves coriaceous, ovate or oblong, 7-12 cm. long, abruptly acute or cuspidate-acuminate, obtuse to subcordate at the base, shortpetiolate; flowers rose or rose-purple, $3.5-5 \mathrm{~cm}$. long, in small dense terminal panicles, the branches and pedicels at first ferruginous-puberulent; corolla shortly 5-lobate, strongly constricted below the middle, strigillose-puberulent outside above the middle, sparsely and minutely lepidote below the middle; stamens included, the filaments dilated and barbate at the base; ovary glabrous; fruit subglobose or broadly ellipsoid, about $3 \mathrm{~cm}$. long, very hard and woody.

A monograph of the genus is being prepared. It is to be expected that this may be found to be the same species that occurs in the coastal regions of South America, under an older name.

Called Indian Honey in British Honduras.

\section{MERREMIA Dennstedt}

Reference: Carlos A. O’Donell, Revisión de las especies americanas de "Merremia." Lilloa 6: 467-554. 1941.

Plants usually herbaceous and twining, small or often very large; leaves entire, lobate, or palmately compound and with 3-7 leaflets, glabrous or pubescent; flowers solitary and axillary or in few-flowered cymes or dichasia, the bracts linear or lanceolate; sepals usually subequal; corolla campanulate, large or small, white, yellow, or purple; filaments equal or nearly so, usually glandular at the base, the anthers spirally twisted in age; ovary usually glabrous, 2-3-carpellate, 4-6-ovulate; style filiform, the stigma globose or biglobose, never exserted; capsule 2-4-celled, longitudinally dehiscent by $4-6$ valves, the pericarp thin and fragile; seeds $4-6$, glabrous or pubescent.

About 60 species, in the tropics of both hemispheres. Probably all the Central American species are included in the following treatment. 


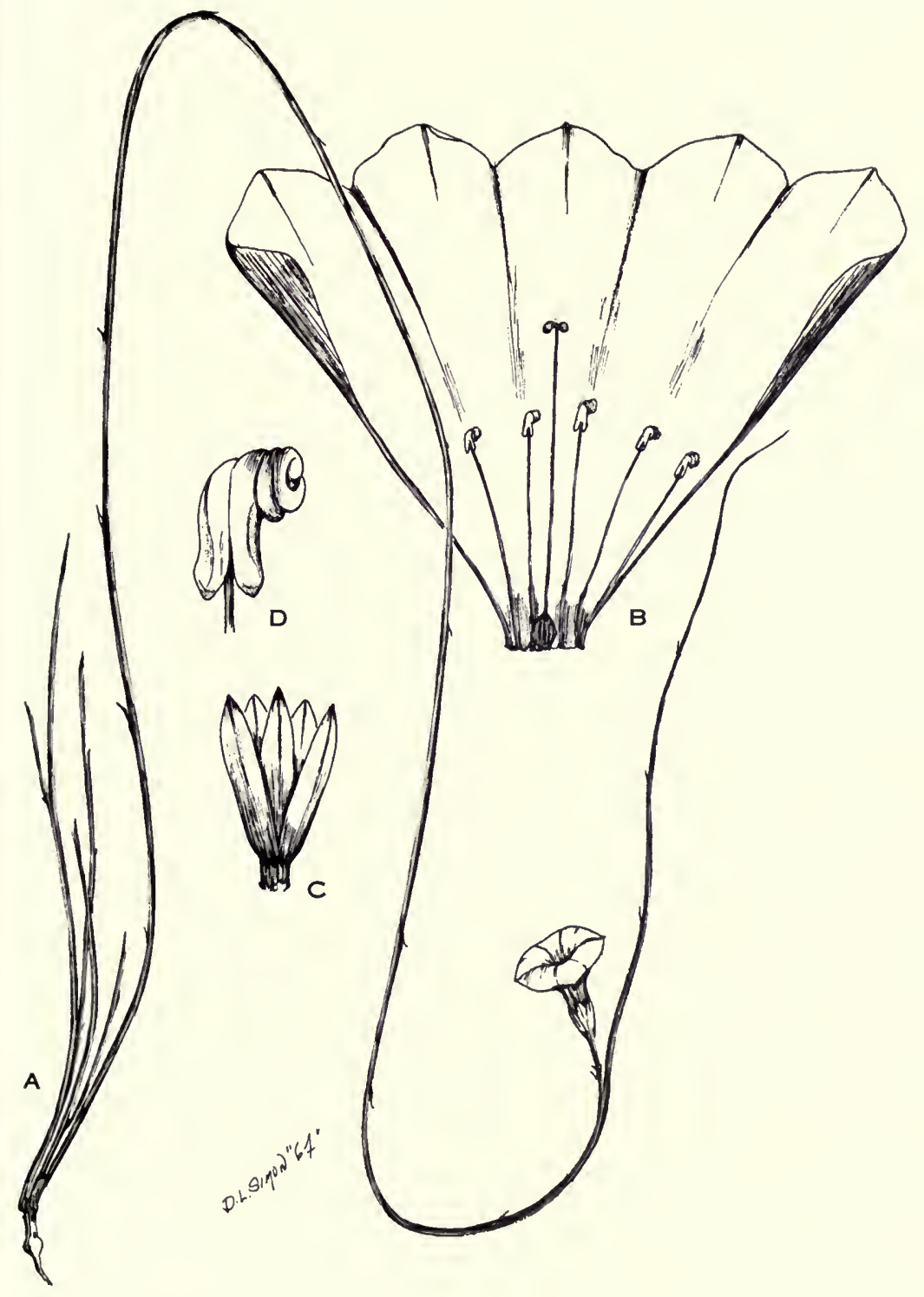

FIG. 10. Merremia aturiensis. A, habit, $\times 1 / 2 ; \mathrm{B}$, corolla expanded showing stamens and pistil, $\times 2$; C, calyx, $\times 2 ; \mathrm{D}$, anther, $\times 15$. 
Leaves reduced to scales; stems not twining M. aturensis.

Leaves normally developed; stems twining.

Leaves entire.

Flowers umbellate; sepals $6-8 \mathrm{~mm}$. long . M. umbellata.

Flowers solitary or on 2-flowered peduncles; sepals $20-30 \mathrm{~mm}$. long.

Leaves compound or deeply lobate.

M. discoidesperma.

Leaves not compound, deeply lobate but the lobes united near the base.

Divisions of the leaves entire; corolla yellow ............. tuberosa.

Divisions of the leaves lobate; corolla white............ dissecta.

Leaves palmately compound, the segments distinct.

Leaflets entire; pubescence not glandular ............... aegyptia.

Leaflets evidently dentate or crenate; pubescence of the calyx of glandular hairs.

Sepals obtuse

M. quinquefolia.

Sepals mostly long-acuminate

M. cissoides.

Merremia aegyptia (L.) Urban, Symb. Antill. 4: 505. 1910. I pomoea aegyptia L. Sp. Pl. 162. 1753. Convolvulus pentaphyllus L. Sp. Pl. ed. 2. 223. 1762. I. pentaphylla Jacq. Coll. Bot. 2: 297. 1788. M. pentaphylla Hallier f., Bot. Jahrb. 16: 552. 1893.

Moist or wet thickets, sometimes a weed in cornfields, $400 \mathrm{~m}$. or less; Zacapa; Chiquimula; Santa Rosa. Mexico; British Honduras to Panama; West Indies; South America; Old World tropics.

A small or large herbaceous vine, the stems usually hirsute with very long, spreading yellowish hairs; leaves long-petiolate, the 5 leaflets elliptic, entire, shortpetiolulate, acuminate or long-acuminate, acute or acuminate at the base, sparsely hirsute on both surfaces; inflorescences long-pedunculate, 6-9-flowered, 15-30 cm. long, hirsute; pedicels 1-3 cm. long; flower buds acute, the sepals oblong, acute, $2 \mathrm{~cm}$. long, hirsute; corolla white, glabrous, $2-3 \mathrm{~cm}$. long; capsule subglobose, $1 \mathrm{~cm}$. in diameter, 4-celled; seeds 4 , glabrous.

Merremia aturensis (HBK.) Hallier f., Bot. Jahrb. 16: 552. 1893. Convolvulus aturensis HBK. Nov. Gen. \& Sp. 3: 96. 1818. Ipomoea aturensis G. Don, Gen. Syst. 4: 226. 1838. I. aphylla Standley, Field Mus. Bot. 11: 139. 1932 (type from Cornhouse Creek, British Honduras, H. H. Bartlett 11316).

In savannas or other open grassy places, little above sea level; British Honduras; Mexico (Chiapas); Colombia to Brazil.

Plants erect or ascending, the stems of ten very numerous, slender, wiry, of ten suffrutescent at the base, striate, glabrous; leaves squamiform, $1.5-2 \mathrm{~mm}$. long; flowers mostly solitary, axillary, the peduncles $1-2 \mathrm{~cm}$. long; sepals oblong-lanceolate, obtuse, mucronulate, 6-10 mm. long; corolla white, $2.5-3.5 \mathrm{~cm}$. long; anthers spirally twisted; ovary glabrous, 4-celled; capsule 4-valvate, seeds 4, glabrous; flower buds acute. 
The small scale-like leaves distinguish this plant from all other Central American members of the Convolvulaceae.

Merremia cissoides (Lam.) Hallier f., Bot. Jahrb. 16: 552. 1893. Convolvulus cissoides Lam. Tabl. Encyl. 1: 462. 1791. Ipomoea cissoides Griseb. Fl. Brit. W. Ind. 473. 1861.

In thickets or waste ground, $1,800 \mathrm{~m}$. or less; Santa Rosa; Suchitepéquez. Mexico; British Honduras; El Salvador and to Costa Rica; West Indies; South America.

A large or small, herbaceous vine, the stems hirsute-pilose with rather short hairs or sometimes glabrate; leaves long-petiolate, the 5 leaflets elliptic or lanceolate, mostly 2-4.5 cm. long, short-petiolulate, acute or acuminate, shallowly dentate or entire, viscid-puberulent or glabrate; flowers usually in few-flowered cymes, rarely solitary, the cymes axillary, usually about equaling the leaves; flower buds acute; sepals $10-15 \mathrm{~mm}$. long, ovate or lance-ovate, long-acuminate, foliaceous, viscid-pubescent; corolla white, $2-3 \mathrm{~cm}$. long; ovary glabrous, 3-4celled, 3-4-ovulate; capsule 7-8 mm. broad, the seeds black, pubescent.

The Maya name of Yucatan is reported as "kixoloc"; "bejuco coronal" (El Salvador).

Merremia discoidesperma (Donn.-Sm.) O'Donell, Lilloa 6:495. 1941. Ipomoea discoidesperma Donn.-Sm. Bot. Gaz. 27. 1889. Quiebra-cajete.

Wet or mixed forest, $2,600 \mathrm{~m}$. or lower; Izabal; Alta Verapaz (type from Pansamalá, Tuerckheim 744); Huehuetenango. Mexico (Chiapas); Nicaragua (?); Cuba; Hispaniola.

Plants stout, twining, glabrous, the stems sometimes several $\mathrm{cm}$. in diameter; leaves on petioles $3-6 \mathrm{~cm}$. long, oval-cordate, $10-15 \mathrm{~cm}$. long, $3-10 \mathrm{~cm}$. broad, entire, coriaceous, acute or acuminate; flowers solitary or the peduncles 2-flowered; sepals oblong, $2-3 \mathrm{~cm}$. long; corolla yellow, $4-5.5 \mathrm{~cm}$. long, glabrous; capsule very large, $3-4 \mathrm{~cm}$. in diameter, subtended by the accrescent and persistent sepals, these in fruit 5-6 cm. long; capsule thin, irregularly dehiscent; seeds usually 1, depressed, $2-3 \mathrm{~cm}$. in diameter, black, velutinous-pubescent.

Merremia dissecta (Jacq.) Hallier f., Bot. Jahrb. 16: 552. 1893. Convolvulus dissectus Jacq. Obs. Bot. 2: 4, t. 28. 1767. Ipomoea sinuata Ortega, Hort. Matr. Dec. 7: 84. 1798. Operculina dissecta House, Bull. Torr. Bot. Club 33: 500. 1906. I. dissecta Pursh, Fl. Amer. Sept. 145. 1814.

Dry to wet thickets, $400 \mathrm{~m}$. or less; El Progreso; Chiquimula; Zacapa. Southern United States; Mexico; Honduras and El Salvador to Panama; West Indies; South America. 
A small or large, herbaceous vine, the stems hirsute or glabrous; leaves palmately divided almost to the base, the $7-9$ segments coarsely sinuate dentate, usually glabrous, sometimes sparsely hirsute; flowers solitary or in 2-4-flowered cymes, the peduncles 5-7 cm. long; pedicels thickened at the apex; sepals $18-25 \mathrm{~mm}$. long, oblong, mucronate, glabrous; corolla white, $3-4.5 \mathrm{~cm}$. long; anthers spirally twisted; ovary glabrous, 2-celled, 4-ovulate; capsule $1.5 \mathrm{~cm}$. in diameter, depressedglobose, surrounded by the accrescent calyx, the sepals in fruit sometimes $3 \mathrm{~cm}$. long; seeds 4 , black, glabrous, $8 \mathrm{~mm}$. long.

Merremia quinquefolia (L.) Hallier f., Bot. Jahrb. 16: 552. 1893. Ipomoea quinquefolia L. Sp. Pl. 162. 1753. Manecilla blanca (fide Aguilar).

Moist or dry thickets or hedges, sometimes in open fields, 1,500 m. or less; Izabal; Zacapa; Chiquimula; El Progreso; Jutiapa; Santa Rosa; Escuintla; Guatemala; Retalhuleu; San Marcos. Mexico; British Honduras to El Salvador and Panama; West Indies; South America.

Usually a small herbaceous vine, sometimes prostrate, the stems glabrous or sparsely hirsute; leaves long-petiolate, the 5 leaflets subsessile, elliptic or lanceolate, glabrous, acute or acuminate, sinuate-dentate, $2-7 \mathrm{~cm}$. long; inflorescence a simple 3-flowered, or rarely compound, dichasium or reduced to a single flower, axillary and usually longer than the leaf, the peduncles glandular-pilose, the pedicels 1-1.5 cm. long; sepals unequal, oblong, obtuse, glabrous, the outer ones 3-5 $\mathrm{mm}$. long, the inner ones 4-7 mm. long; corolla white, $1.5-2.5 \mathrm{~cm}$. long; capsule glabrous, 7-8 mm. broad, subglobose, 4-celled; seeds 4, pubescent.

Called "white cowslip" in British Honduras.

Merremia tuberosa (L.) Rendle in Thist.-Dyer, Fl. Trop. Africa 4: 104. 1905. Ipomoea tuberosa L. Sp. Pl. 160. 1753. Operculina tuberosa Meissn. in Mart. Fl. Bras. 7: 212. 1869. I. nuda Peter in Engler \& Prentl, Pflanzenf. IV. 3a: 31. 1891, hyponym (based on Guatemalan material). Quiebra-machete (Suchitepéquez; probably an erroneous rendering of quiebra-cajete); rosa de barranco; foco de luz; bejuco de golondrina; quinamacal (Petén).

Moist or wet thickets, 1,200 m. or lower; Petén; Alta Verapaz; Baja Verapaz; Izabal; Escuintla; Suchitepéquez; Retalhuleu; Quiché; Quezaltenango; San Marcos. Mexico; British Honduras to Panama; West Indies; South America.

Usually a very large, herbaceous vine, of ten growing over good-sized trees, the stems stout, glabrous or nearly so; leaves large, long-petiolate, $8-15 \mathrm{~cm}$. long or more, deeply 7-lobate, of ten almost to the base, the lobes lanceolate to elliptic, acuminate, entire, glabrous; peduncles $10-20 \mathrm{~cm}$. long, the pedicels 1-2 cm. long, clavate, the flowers usually several in each inflorescence, sometimes solitary; sepals unequal, the outer ones $2.5-3 \mathrm{~cm}$. long in anthesis, oblong, obtuse, mucronate; 
corolla bright yellow, 5-6 cm. long; anthers spirally twisted; capsule irregularly dehiscent, with 4 or fewer seeds, 2-celled; sepals in fruit as much as $7 \mathrm{~cm}$. long; seeds to $17 \mathrm{~mm}$. in diameter, covered with a very dense, short and black pubescence.

Called "seven-fingers" in British Honduras. In Honduras the vine is called "mala hierba," it being claimed that the huge tuberous roots are poisonous to pigs and horses. In the Canal Zone this is known as "Tivoli vine," because it was formerly at least planted about the Tivoli Hotel in Panama City. It is one of the more showy of Central American morning-glories and under favorable conditions attains a great size and is covered with the large blossoms. In Guatemala the dry capsules with their enveloping sepals are much used as decorations in houses or on alters, either in their natural brown color or embellished with silver or gold paint.

Merremia umbellata (L.) Hallier f., Bot. Jahrb. 16: 552. 1893. Convolvulus umbellatus L. Sp. Pl. 155. 1753. Ipomoea polyanthes Roem. \& Schult. Syst. 4: 234. 1819. Cajete; quilamulillo (fide Aguilar).

Dry to wet thickets or hedges, often in second growth, or a weed in cultivated ground, 1,500 m. or less; Petén; Alta Verapaz; Baja Verapaz; Izabal; El Progreso; Zacapa; Jutiapa; Santa Rosa; Escuintla; Guatemala; Sololá; Suchitepéquez; Retalhuleu; San Marcos. Mexico; British Honduras to El Salvador and Panama; West Indies; South America; Old World tropies.

A small or large, herbaceous vine, the stems slender, glabrate; leaves longpetiolate, narrowly triangular to broadly ovate, usually long-acuminate, cordate or hastate at the base, densely pubescent or almost glabrous, entire; inflorescence umbellif orm, usually many-flowered, peduncles $6-15 \mathrm{~cm}$. long; flowers buds obtuse; sepals equal, oblong, 6-8 mm. long, glabrous or pubescent, rounded at the apex, scarious-margined; corolla bright yellow, $3-3.5 \mathrm{~cm}$. long, glabrous; anthers not twisted; ovary glabrous, globose, 2-celled, 4-ovulate; capsule $8 \mathrm{~mm}$. in diameter, regularly 4-valvate; seeds 4 and 5-6 $\mathrm{mm}$. long, densely pubescent.

Known in El Salvador as "cuelga-tabaco," "jicama cimarrona," and "cuajo de ule." The tough stems are used commonly for hanging tobacco to dry, while the milky sap has been utilized for coagulating Castilla rubber sap. The plant is a common weed through much of Central America. The abundant yellow flowers, in head-like clusters, are rather pretty, and they apparently remain open throughout the day. 


\section{OPERCULINA Manso}

Reference: H. D. House, Studies in the North American Convolvulaceae, II. The genus Operculina. Bull. Torr. Bot. Club 33: 495-503. 1906.

Large or small vines, herbaceous or somewhat woody, the stems, petioles, and pedicels of ten winged; leaves entire or variously lobate, of ten cordate; flowers large, axillary, in few-flowered cymes or solitary; sepals large, scarious, glabrous, enlarged in fruit and becoming somewhat coriaceous, of ten irregularly erose on the margins; disk small or none; corolla large, broadly funnelform or campanulate, white, yellow, or salmon-red; stamens and style included, the anthers twisted, at least in age; ovary glabrous, each cell with 2 ovules, style one, simple, filif orm, included, the stigma biglobose; capsule large, dry, epicarp circumscissle in or above the middle, the upper part more or less fleshy and separating from the lower part and from the endocarp.

Species perhaps 20 in the tropics of both hemispheres. One or two additional species in Mexico, no others are known from Central America.

Leaves entire, cordate; peduncles winged

O. pteripes. Leaves digitate, lobate or dentate; peduncles not winged

O. pinnatifida.

Operculina pinnatifida (HBK.) O'Donell, Lilloa 23: 432. 1950. Convolvulus pinnatifida HBK. Nov. Gen. \& Sp. Pl. 3: 85. 1819. Ipomoea pinnatifida G. Don, Gen. Syst. 4: 280. 1838. Merremia pinnatifida Hallier f. in Engler, Bot. Jahrb. 16: 552. 1893. Ipomoea ornithopoda Robinson, Proc. Am. Acad. 19: 183. 1893. Operculina ornithopoda House, Bot. Gaz. 44: 414. 1907. Operculina pectinata House, Muhlenbergia 5: 69. 1909. Quiebra cajete.

A vine in thickets or growing over trees at $300 \mathrm{~m}$. or less; Petén; Huehuetanango. Texas; Mexico (widely distributed).

A glabrous rampant vine, the internodes of the stems to $15 \mathrm{~cm}$. long. Leaves with petiole shorter than the blade, the blade ovate in outline, $2-12 \mathrm{~cm}$. long and about as broad, with 5-9 pinnate divisions or lobes, the segments linear to ovate or rarely obovate and sometimes lobulate, acute or acuminate, the base cordate or subtruncate; inflorescence a simple, axillary 2-3-flowered dischasium or cyme, sometimes with a single flower, the peduncles 3-12 cm. long, sometimes subalate above; sepals obovate, obtuse, glabrous, $15-16 \mathrm{~mm}$. long and 10-13 $\mathrm{mm}$. broad; corolla white, subcampanulate, $3-5 \mathrm{~cm}$. long and about as broad, the interpetaline area sericeous; capsules subglobose-depressed, 1.5-2 cm. in diameter; seeds black, 6-7 mm. long.

Operculina pteripes (G. Don) O'Donell, Lilloa 23: 435. 1950. Calonyction pteripes G. Don, Gen. Syst. 4: 264. 1838. Ipomoea 


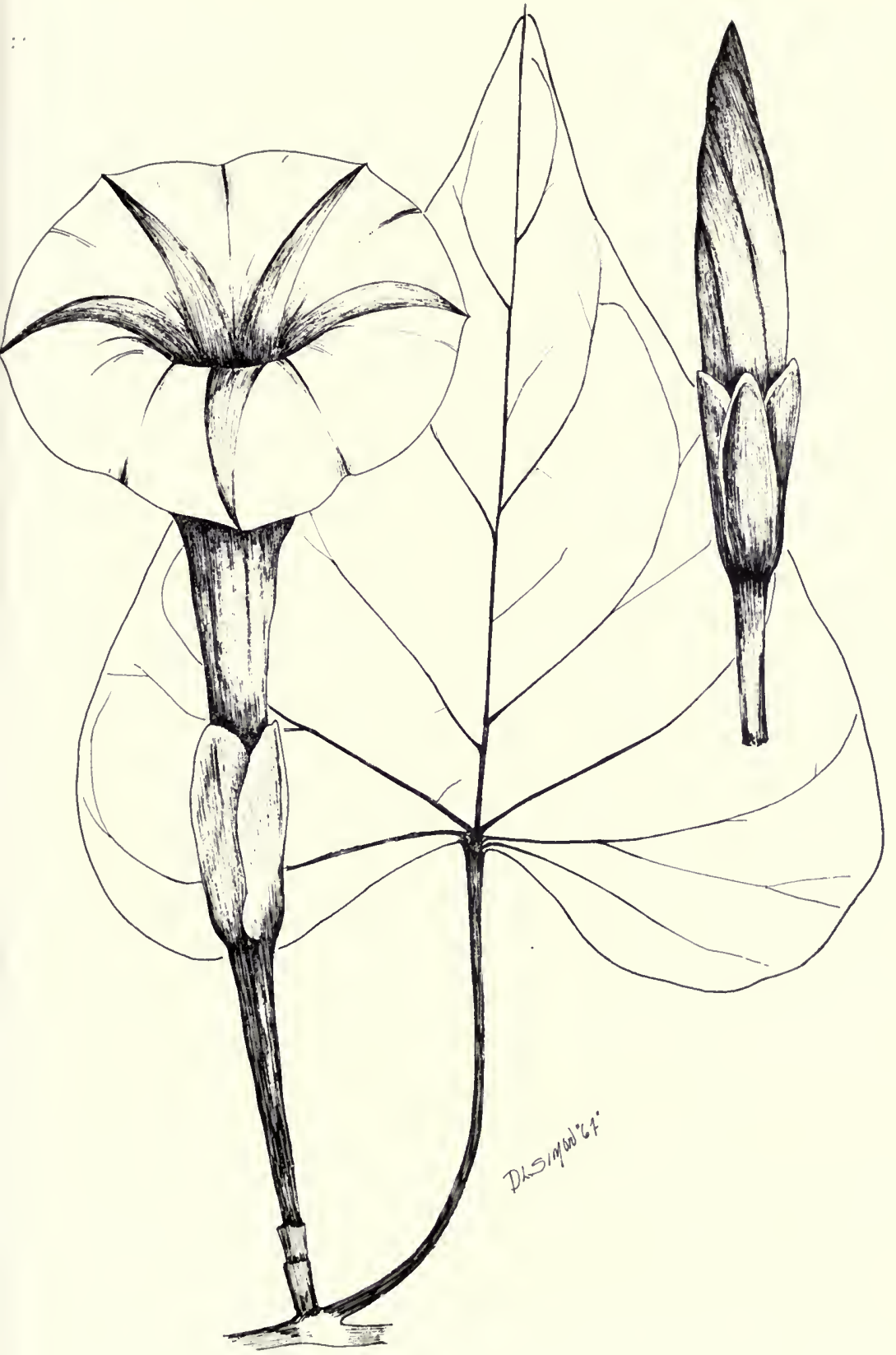

FIG. 11. Operculina pteripes. A, habit and bud, all natural size. 
alatipes Hook. Bot. Mag. 88: t. 5330. 1862. Operculina alatipes House, Bull. Torr. Bot. Club 33: 499. 1906. Chorreque (Jutiapa).

A vine in thickets, usually $950 \mathrm{~m}$. or less; Chiquimula; Jutiapa; Santa Rosa; Escuintla; perhaps in all lowland departments. Mexico to El Salvador and Panama. South America.

A large herbaceous vine, growing over good-sized trees, glabrous throughout; leaves long petiolate, ovate, mostly $3-8 \mathrm{~cm}$. long, long-acuminate, cordate at the base, entire; peduncles narrowly winged, 2-7-flowered, usually strongly curved, the pedicels thickened; calyx $2.5 \mathrm{~cm}$. long, the sepals acute or acuminate; corolla almost salverform, 6-7 cm. long, salmon-colored or brick-red.

Known in El Salvador as "mechoacan," "quiebra-cajete," and "campanilla chocolate." The large turnip-like roots often weigh several pounds. Among all the related plants of Guatemala, this may be recognized at once by the unusual color of the flowers, which are attractive.

\section{QUAMOCLIT Moench}

References: H. D. House, Studies in North American Convolvulaceae-V. Quamoclit, Bull. Torr. Club 36: 595-603. 1909. C. A. O'Donell, Las especies americanas de Ipomoea L., Sect. “Quamoclit" (Moench.) Griseb., Lilloa 29: 19-86. 1959.

Herbaceous vines; leaves alternate, entire, lobate, or pinnately divided; flowers small or large, of ten showy, usually red, yellow, or greenish, axillary, in of ten dichotomous, few-many-flowered cymes; sepals membranaceous or herbaceous, equal or nearly so, of ten appendaged at the apex; corolla tube short or elongate, the limb more or less salverform or funnelform, shallowly or rather deeply lobate; stamens and style exserted, usually declinate, the filaments filiform; ovary 2-celled, 4-ovulate; stigma capitate; capsule globose or somewhat elongate, the style of ten persistent; seeds glabrous.

About a dozen species, in tropical America. Only the following are known from Central America. The genus perhaps is not distinct from Ipomoea.

Leaves pinnately parted into linear segments; sepals not awned at apex.

Leaves entire or palmately lobed; sepals awned at apex.

Q. pennata.

Corolla limb suburceolate with very short tube; inflorescence a bifid cyme with

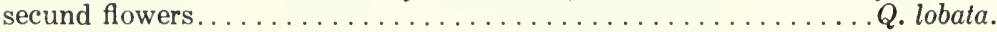

Corolla limb campanulate, tube long or short; inflorescence cymose or corymbiform, the flowers not secund.

Limb of corolla deeply lobed, the lobes $0.7-1.5 \mathrm{~cm}$. long ........ vitifolia. Limb of corolla subentire or shallowly lobed, the lobes broad and short.

Branches of inflorescence short, corymbiform; corolla yellow or sometimes reddish . . . . . . . . . . . . . . . . . . . . . . . . . . .

Branches of inflorescence long; corollas red or reddish. 
Leaves lobate. Q. hederifolia.

Leaves not lobate, rarely dentate. Q. cholulensis.

Quamoclit cholulensis (HBK.) G. Don, Gen. Hist. 4: 259. 1838. Ipomoea cholulensis HBK. Nov. Gen. \& Sp. Pl. 3: 88. 1819; O'Donell, Lilloa 29: 28. 1959. Q. coccinea var. pubescens (Schlecht. \& Cham.) G. Don, 1.c. 258. Q. coccinea of authors, in part. Campanita roja.

Vines growing in thickets or over other plants, often weedy, 1,000-1,500 m.; Alta Verapaz; Sacatepéquez; Guatemala; Chimaltenango; Santa Rosa. El Salvador; Honduras; Nicaragua; Costa Rica. South America.

An annual or possibly more enduring, much branched, glabrous or tomentose. Leaves ovate or lanceolate-ovate, cordate, entire or sometimes dentate, acute to acuminate or caudate, tomentose to pilose or nearly glabrous, $2-12 \mathrm{~cm}$. long and 1-7 cm. broad; inflorescence cymose, 2-8-flowered or rarely the flowers solitary, peduncles $7-19 \mathrm{~cm}$. long; pedicels $0.5-1.5 \mathrm{~cm}$. long; exterior sepals oblong or ovate, $2.5-3.5 \mathrm{~mm}$. long and $1.5-2.5 \mathrm{~mm}$. broad, obtuse with a subterminal awn, glabrous or pubescent; the interior sepals elliptic to ovate, $3-4.5 \mathrm{~mm}$. long, $2-3 \mathrm{~mm}$. broad, awned; corolla hypercratiform, tube slightly spread at the apex, $1.5-2.5 \mathrm{~cm}$. long and $0.15-0.3 \mathrm{~cm}$. in diameter, limb broadly campanulate, obscurely 5-lobate; stamens barely exserted; ovary ovoid, 4-locular, 4-ovulate; stigma biglobose; capsules subglobose.

This is one component of the complex that has been called $Q$. coccinea (L.) Moench. Most Central American material has been determined with that name. O'Donell, in his revision of this group, limits $Q$. coccinea to the United States.

Quamoclit hederifolia (L.) G. Don, Gen. Hist. 4: 259. 1838. I pomoea hederifolia L. Syst. Nat. ed. 10.925. 1759. Q. brevipedicellata Hallier f. Bull. Herb. Boiss. 7: 416. 1899. Q. coccinea var. hederifolia House, Ann. N. Y. Acad. Sci. 18: 262. 1908. Q. coccinea, of many authors, in part. Campanita; xocxop (Huehuetenango).

Moist thickets or hedges, often a weed in cornfields, $1,800 \mathrm{~m}$. or less; Zacapa; Chiquimula; Jutiapa; Santa Rosa; Escuintla; Sacatepéquez; Chimaltenango; Retalhuleu; Huehuetanango. Southern United States; Mexico; British Honduras to Panama; West Indies; South America; Malaysia; Africa.

Usually a small herbaceous vine, glabrous to laxly pubescent; leaves longpetiolate, ovate or rounded-ovate, $4-10 \mathrm{~cm}$. long; acute or acuminate, cordate at the base, (rarely) entire, shallowly to deeply angulate-lobate; peduncles equaling or longer than the leaves, few-many-flowered; sepals oblong, 4-6 $\mathrm{mm}$. long, the outer ones with subulate awns $2-5 \mathrm{~mm}$. long arising on the outside below the apex; 


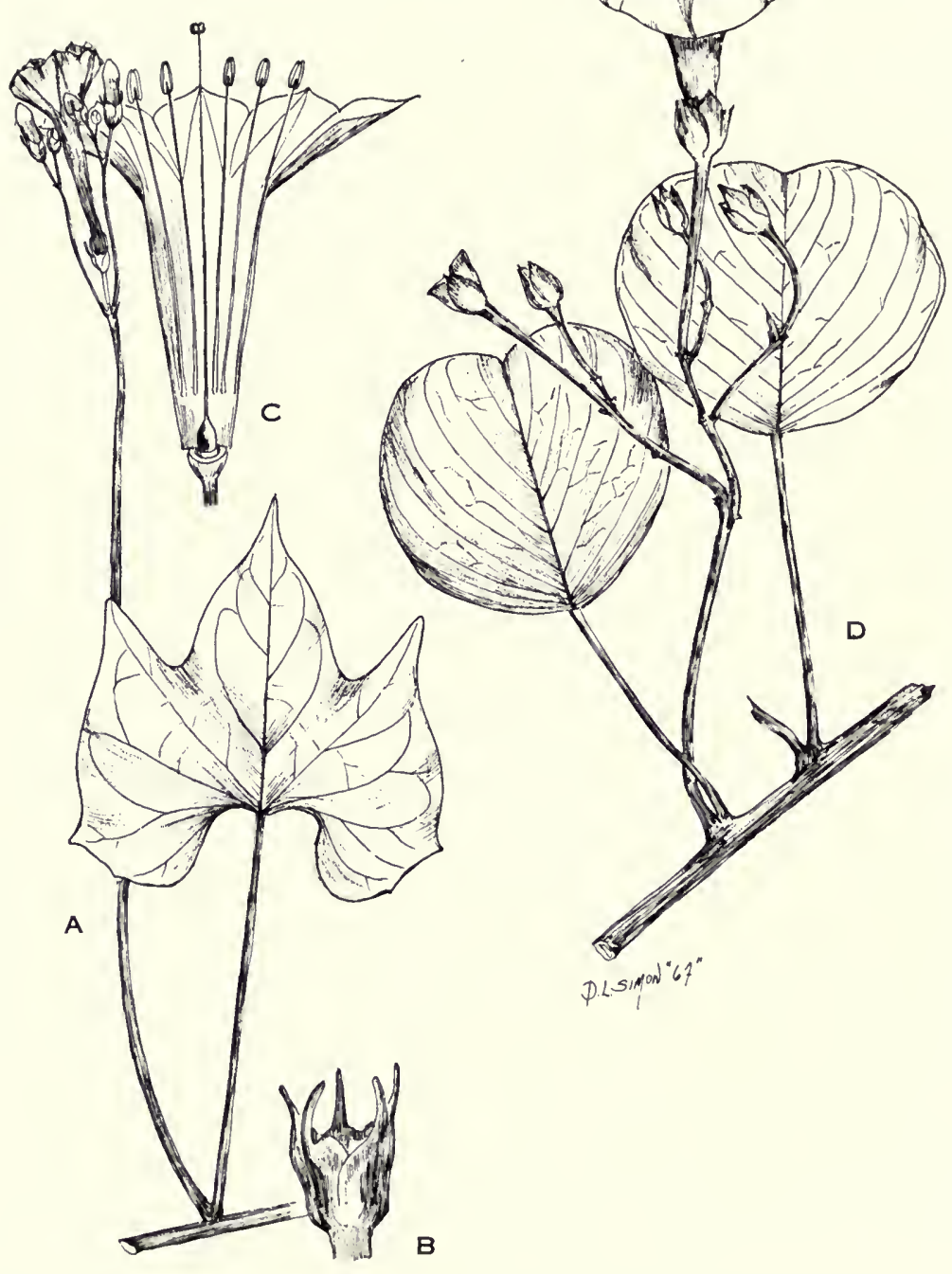

FIG. 12. Quamoclit hederifolia. A, habit, $\times 1 / 2 ; \mathrm{B}$, calyx, $\times 2$; corolla and pistil, natural size (after Flora Brasiliensis). Ipomoea pes-caprae. $\mathrm{D}$, habit, $\times 1 / 2$. 
corolla scarlet, the tube 3-4 cm. long, slightly dilated near the apex, the almost rotate limb 1.5-2 cm. broad, 5-angulate; capsule globose, 6-7 mm. long.

Called "Indian creeper" in British Honduras; "hiedra colorada" (Yucatan). The plant is a weedy one, not very decorative, in spite of its brilliantly colored flowers.

Quamoclit lobata (Llave \& Lex.) House, Bull. Torr. Bot. Club 36: 602. 1909. Mina lobata Llave \& Lex. Nov. Veg. Descr. 3. 1824. Ipomoea versicolor Meissn. in Mart. Fl. Bras. 7: 220. 1869. Bandera española; banderita de España; banderita española.

Cultivated occasionally for ornament. Perhaps native of Mexico.

A slender herbaceous vine; leaves slender-petiolate, ovate, deeply cordate at the base, deeply 3-lobate, the middle lobe constricted near the base, the lateral lobes of ten lobate, glabrous or nearly so; peduncles much longer than the leaves, dichotomous, few-many-flowered, the flowers secund; sepals $3-4 \mathrm{~mm}$. long, the apical appendages recurved; corolla bright yellow, tinged above with red, about $2 \mathrm{~cm}$. long, the tube proper very short, scarcely exceeding the calyx, the throat much dilated, $1 \mathrm{~cm}$. broad, the margin somewhat constricted, with 5 very small and short lobes; stamens twice as long as the corolla.

A showy and handsome plant, deserving wide cultivation. The plants wither when the rains stop, but if watered might remain in bloom for a longer period. The name "bandera española" is given because the corollas bear the colors of the flag of Spain.

Quamoclit lutea (Hemsl.) Hallier f. in Engler, Bot. Jahrb. 16: 557. 1893. I pomoea lutea Hemsl. Diagn. Pl. Nov. 34. 1878 (type from Guatemala, Salvin \& Godman); in Godman \& Salvin, Biol. Cent. Am. Bot. 2: 389, t. 60. 1882. I. lutea var. rubra O’Donell, Lilloa 29: 67. 1959.

Moist thickets or forest, 1,300-1,500 m.; Guatemala; Chimaltenango; Sacatépequez; Quezaltenango; San Marcos; Suchitipéquez. Southern Mexico.

A large vine, glabrous throughout or nearly so, herbaceous; leaves long petiolate, cordate or hastate at the base, sometimes broadly ovate and entire, usually 3 -lobate, the lobes acute to long-acuminate, the outer ones of ten angulate; peduncles greatly elongate, the flowers usually numerous, long-pedicellate, in small compact cymes; sepals $5 \mathrm{~mm}$. long, the slender appendages of equal or greater length; corolla yellow or orange-yellow, $5 \mathrm{~cm}$. long, the tube slightly curved, very gradually dilated upward, $7-8 \mathrm{~mm}$. broad in the throat, the lobes rounded, small, scarcely more than $8 \mathrm{~nm}$. long; stamens shortly exserted.

This species was much misunderstood by House, who treated it as a variety of $Q$. coccinea, from which it is altogether distinct. 
Quamoclit pennata (Desr.) Bojer, Hort. Maurit. 224. 1837. I pomoea Quamoclit L. Sp. Pl. 159. 1753. Convolvulus pennatus Desr. in Lam. Encycl. 3: 567. 1791. Q. vulgaris Choisy, Mem. Soc. Phys. Hist. Nat. Geneve 6: 434. 1833. Clarincillo; clarin.

Probably native in tropical Asia, but planted in many temperate and tropical regions for ornament; grown commonly in Guatemalan gardens, at low and middle elevations; naturalized in many places, usually in moist thickets or in hedges, 1,500 m. or less; Izabal; Zacapa; Chiquimula; Jutiapa; Escuintla; Guatemala; Suchitepéquez; Retalhuleu. British Honduras. Naturalized widely in tropical America.

A slender glabrous vine, often several meters long; leaves $2-10 \mathrm{~cm}$. long, parted to the costa into very numerous linear segments; peduncles mostly longer than the leaves and 1-2-flowered, the pedicels $2-3 \mathrm{~cm}$. long, thickened in fruit; sepals oblong, obtuse, mucronate, not appendaged, $3-5 \mathrm{~mm}$. long; corolla scarlet, 2.5-3.5 $\mathrm{cm}$. long, the tube slender, the limb rotate, with short ovate acute lobes; capsule ovoid, 8-10 mm. long.

Known in El Salvador by the names "clavellina," "cundeamor," and "cambustera" (Yucatan). The plant is often grown in the United States, where usually it is called “cypress vine." Plants with white flowers sometimes are found in cultivation, but they have not been noted in Central America.

The specific name of this plant is often spelled pinnata, which is the form most commonly used in botanical Latin. The original, however, uses the form we have followed which is preferred in classical Latin.

Quamoclit vitifolia (Cav.) G. Don, Gen. Syst. 4: 259. 1838. Calboa vitifolia Cav. Icon. 5: 51, t. 476. 1799. Ipomoea peduncularis Bertol. Fl. Guat. 408, t. 38. 1840 (type from Escuintla, Velásquez). Ipomoea hartwegii Meissn. in Mart. Fl. Bras. 7: 220. 1869 (syntype from Guatemala, Hartweg 603). Bejuco de mariposa.

Usually in moist or wet thickets, often in second growth, $1,500 \mathrm{~m}$. or less; Alta Verapaz; Zacapa; Jutiapa; Santa Rosa; Escuintla; Guatemala; Sacatepéquez; Suchitepéquez; Retalhuleu; Quezaltenango; San Marcos. Mexico; El Salvador to Panama.

Usually a large coarse herbaceous vine with milky sap, often climbing over medium-sized trees, glabrous; leaves long-petiolate, about as broad as long, cordate or cordate-sagittate at the base, rarely subentire but usually deeply trilobate, the lobes ovate to lanceolate, acute to long-acuminate; inflorescence few-manyflowered, the flowers in dense or open cymes, peduncles usually much longer than the leaves; sepals ovate or rounded, $4-5 \mathrm{~mm}$. long, the terminal appendages of less or equal length; corolla $2.5-3.5 \mathrm{~cm}$. long, thick in texture, bronze-yellow, brownish 
yellow or pale greenish yellow, the lohes and upper part of the tube usually tinged with maroon or brown, the tube proper short and thick, the throat abruptly dilated and funnelform, the limb deeply 5 lobate, the lobes ovate, obtuse or acutish, ascending; stamens long-exserted; capsule globose-ovoid, $7 \mathrm{~mm}$. long.

Called "campanilla" and "ala de cucaracha" in El Salvador. This plant is less conspicuous than other species of Quamoclit, the color of the flowers being bizarre but rather dull.

This species has often been considered to include Q. globosa (Llave \& Lex.) G. Don or that is a distinct species. O'Donell considers $Q$. globosa a synonym of Ipomoea hastigera HBK., a species of Quamoclit as delimited here, limited to a small area in Mexico.

\section{TURBINA Rafinesque}

Woody vines, pubescent or glabrous; leaves petiolate, cordate and entire; peduncles axillary, 1-many-flowered, of ten paniculate at the ends of the branches; sepals ovate or lanceolate, the outer ones prominently sphacelate, of ten very unequal and accrescent in fruit; corolla usually large and funnelform; stamens and style usually not exserted; ovary glabrous, with 2 cells; stigmas 2 , globose; fruit dry, usually ligneous, globose or ellipsoid, 1-celled and commonly 1 seeded; seeds glabrous.

Perhaps a half dozen species in America. Only the following is known from Central America.

S. J. van Ooststroom, Blumea 5: 355. 1943, points out that our species does not belong in the genus Rivea Choisy and transferred it to Legendrea, a genus more recent than Turbina, with the same circumscription.

Turbina corymbosa (L.) Raf. Fl. Tell. 11: 81. 1836. Convolvulus corymbosa L. Syst. Nat. ed. 10. 293. 1759. Rivea corymbosa Hallier f. in Engler, Bot. Jahrb. 18: 157. 1893. Convolvulus sidaefolia HBK. Nov. Gen. \& Sp. 3: 99. 1818. Ipomoea sidaefolia Choisy, Mem. Soc. Phys. Hist. Nat. Geneve 6: 459. 1833. Xtabentun (Petén, Maya).

Moist or wet thickets or hedges, often in second growth, $650 \mathrm{~m}$. or less; Petén; Alta Verapaz; Izabal; El Progreso; Zacapa; Santa Rosa. Mexico; British Honduras to Panama; West Indies; South America. Introduced in Phillipines.

A large or small, woody vine, of ten climbing over small trees, glabrous or nearly so; leaves slender-petiolate, ovate, $4-10 \mathrm{~cm}$. long, acute or acuminate, cordate at the base, entire; peduncles axillary, equaling or longer than the leaves, few-many-flowered, often forming large dense terminal panicles, the pedicels slender; sepals oblong, persistent, the inner ones $8-12 \mathrm{~mm}$. long, almost twice as 


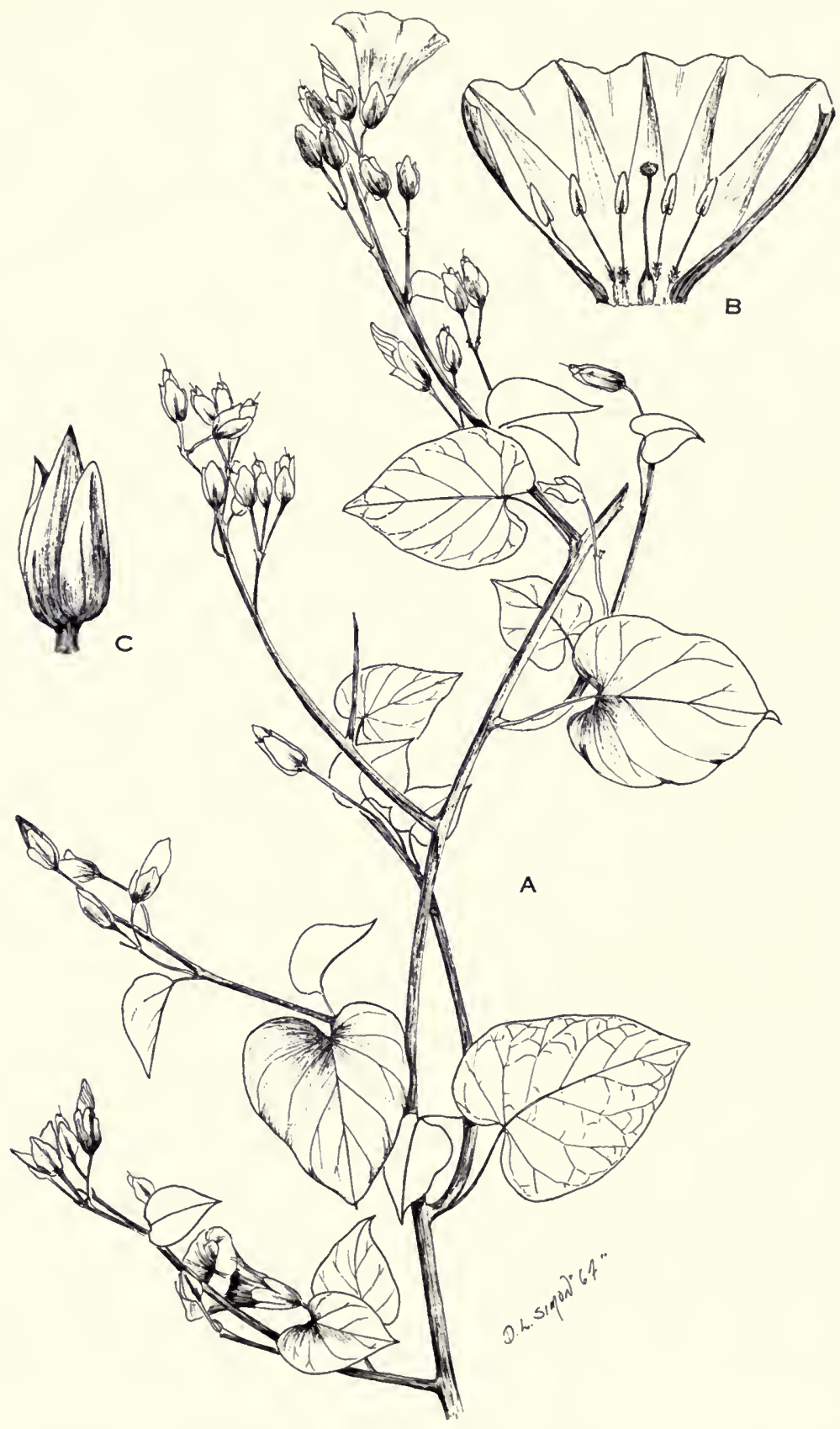

FIG. 13. Turbina corymbosa. A, habit, $\times 1 / 2 ; \mathrm{B}$, dissected corolla showing stamens and pistil, natural size; C, calyx, $\times 4$. 
long as the outer ones; corolla white, $2.5-3 \mathrm{~cm}$. long; capsule ovoid-oblong, acute, shorter than the inner sepals, 1-seeded.

Called "pascua" and "flor de pascua" in Yucatan, presumably in allusion to the fact that it is in bloom there at Christmas time. In Panama the latex is said to be employed for coagulating Castilla rubber latex.

\section{Excluded:}

Rivea Bernoulliana (Peter) Hallier f. in Engler, Bot. Jahrb. 18: 158. 1893. Ipomoea bernoulliana Peter in Engler \& Prantl, Pflanzenf. IV. Abt. 3a: 30. 1891, nomen nudum.

This name is based upon material from Guatemala collected by Bernoulli but no description of the plant has been published.

\section{POLEMONIAGEAE. Phlox Family}

\section{Dorothy N. GiBson}

References: Benth. in DC. Prodr. 9: 302-322. 1845. Benth. \& Hook., Gen. Pl. 2: 820-824. 1876. Brand in Engler, Pflanzenr. IV, 250: 1-203. 1907. Grant, Natural History of the Phlox Family, 1: $1-273.1959$.

Annual or perennial herbs, shrubs or small trees, usually erect (scandent in Cobaea), usually somewhat pubescent, of ten glandular; leaves alternate (lower ones sometimes opposite), entire, serrate, or pinnately divided; inflorescences usually cymose, the flowers rarely solitary and axillary; flowers bisexual, actinomorphic or weakly zygomorphic; calyx 5-lobed, imbricate or valvate, persistent, usually accrescent; corolla tubular (campanulate in Cobaea), 5-lobed, lobes contorted, salverform to rotate; stamens 5 , inserted on corolla tube at various, of ten unequal heights, anthers versatile, bilocular, introrse; ovary superior, inserted on disc, usually trilocular (rarely 2 or 5 carpels), placentation axile, ovules 1-many on each placenta; style filiform, stigmatic branches 3 (rarely 2 or 5 ); fruit a capsule dehiscing loculicidally (septicidally in Cobaea) or rarely indehiscent; seeds usually small, sometimes winged, of ten mucilaginous when wetted; embryo spatulate; endosperm usually firm, abundant.

The Polemoniaceae, containing 317 reporterl species, are naturally distributed throughout North, Central and South America and Eurasia, occurring most frequently in temperate regions. A few occur as 
weeds in Africa and Australia. Of the 15 to 18 genera (not always very distinct) only three, Bonplandia, Loeselia, and Cobaea are known from Central America. Although Gilia capitata Sims and Phlox Drummondii Hook., are cultivated occasionally for ornament and sometimes sold in the markets, neither has yet been reported as an escape.

Plants scandent by tendrils

Cobaea.

Plants not scandent, without tendrils.

Calyx foliaceous; leaves lyrate lobate or pinnately lobed

Bonplandia.

Calyx membranaceous between costae; leaves dentate or serrate......Loeselia.

\section{BONPLANDIA Cav.}

Reference: A. Brand in Engler, Pflanzenr. IV, 250: 179-181, f. 39. 1907.

Annual herbs, usually erect, sometimes becoming bushy, more or less glandular-pubescent throughout; leaves alternate, simple, pinnately divided, entire or with serrate margins, sessile or petiolate; inflorescence usually loose, terminal panicles composed of axillary, short-pedicellate flowers usually in pairs (rarely 1 or 3) or flowers may occur in axils without becoming paniculate; calyx persistent, herbaceous, tubular, slightly zygomorphic; corolla blue to purple, bilabiate, the tube gibbous, the lobes unequal, about equalling or shorter than the tube; stamens glabrous, inserted at different levels on upper part of tube, about equalling the corolla or shortly exserted; ovary broadly ellipsoid to ovoid, superior, on small disc; mature capsule elliptic-ovoid, glabrous, much shorter than the accrescent calyx, dehiscing loculicidally, each locule containing one small, oblong, narrowly winged seed.

Only one of the two known species is in Guatemala.

Bonplandia geminiflora Cav. Anal. Hist. Nat. Madrid 2: 131. 1800. Caldasia heterophylla Willd. Hort. Berol. t. 71, 1807; Benth. in DC. Prodr. 9: 320. 1845.

Known in Guatemala only from Azacualapa, Jutiapa, 400 m., Heyde \& Lux 6223. Widely distributed in Mexico, 270-3,150 m., in wet, shady places, sometimes growing in water, or in rocky canyons.

Plants $20-60 \mathrm{~cm}$. tall, the stems simple or branched, densely glandular-pilose above; leaves petiolate, usually ovate but may be oblanceolate, spatulate, lyrateovate, obate or pinnate-lobate below, usually coarsely and irregularly serrate, acuminate, narrowed to the base, thin, sparsely or densely villous or glandularvillous; flowers on short, densely pilose pedicels; calyx ca. $1 \mathrm{~cm}$. long in maturity, densely glandular-pilose, prominently nerved, the triangular lobes much shorter than the tube; corolla purple, glabrous, $1.5-2 \mathrm{~cm}$. long; mature capsule ca. $0.5 \mathrm{~cm}$. long. 


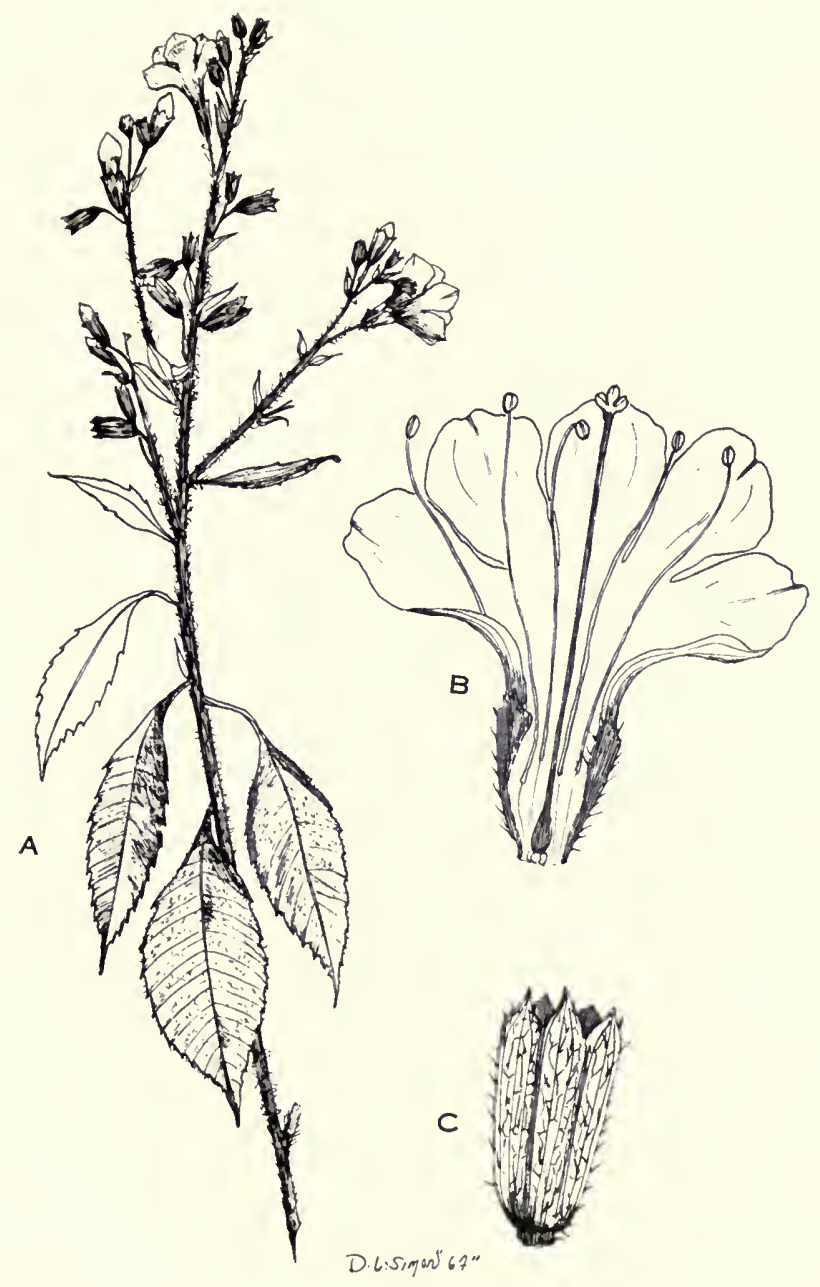

FIG. 14. Bonplandia geminiflora. A, habit, 1/2 natural size; B, corolla dissected to show stamens and pistil, $\times 2$; C, fruiting calyx, $\times 3$. 
The leaves are highly variable; some which are pinnate-lobate with long, almost linear lobes, suggest those of some Cruciferae.

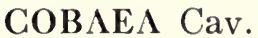

Reference: Paul C. Standley, A revision of the genus Cobaea, Contr. U. S. Nat. Herb. 17: 448-458, t. 26-31. 1914.

Herbs or sub-shrubs, probably always annual (fide Standley), scandent by coiled tendrils, somewhat pubescent; leaves alternate, pinnately compound, sessile to short-petiolate, the 4-6 leaflets entire, usually short-petiolulate, the terminal leaflet usually modified as a tendril; flowers axillary, usually solitary, occasionally $2-3$ on long peduncles; calyx persistent, herbaceous, the 5 sepals broad to narrow, usually divided almost to base but may be united for one-third to more than onehalf their length, regular; corolla green, greenish-white, greenish-yellow, yellow, pale pink or lavender to purplish-green, sometimes striped, campanulate, usually exceeding the calyx, lobes orbicular to ovate or broadly triangular to acuminate, sometimes caudate; stamens equally inserted near base of corolla tube, usually exserted, filaments slender, wooly at point of insertion with pubescence sometimes extending down on to tube, sometimes pubescent to wooly near apex, anthers versatile; style usually exserted, stigma 3-lobed or branched; ovary superior on a large, 5-lobate disc, glabrous, elliptic-ovoid, tri-carpellate, tri-locular; mature capsule exceeding calyx, ellipsoid or elliptic-ovoid, coriaceous, dehiscing septicidally, each locule containing 2 to several large, flat, winged seeds.

Of the 19 species described, six are known from Guatemala. An American genus of humid, montane forests and thickets, sometimes persisting in hedges along cleared fields and slopes, it ranges from Mexico throughout Central America and in the Andes from Venezuela to Colombia and northern Chile.

Cobaea scandens has long been cultivated as an ornamental in Europe as well as the Americas.

Sepals broadly rounded at apex. . . . . . . . . . . . scandens. Sepals attenuate to acute.

Sepals ovate to broadly ovate.................... skutchii. Sepals oblong-lanceolate to linear-lanceolate.

Corolla lobes acuminate. .........................

Corolla lobes short, rounded, ovate-obtuse or broadly triangular.

Corollas $2.5-4 \mathrm{~cm}$. long.

Corollas $2.5 \mathrm{~cm}$. long . . . . . . . . . . . . . steyermarkii.

Corollas $3-4 \mathrm{~cm}$. long .................... triflora.

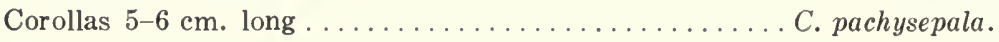




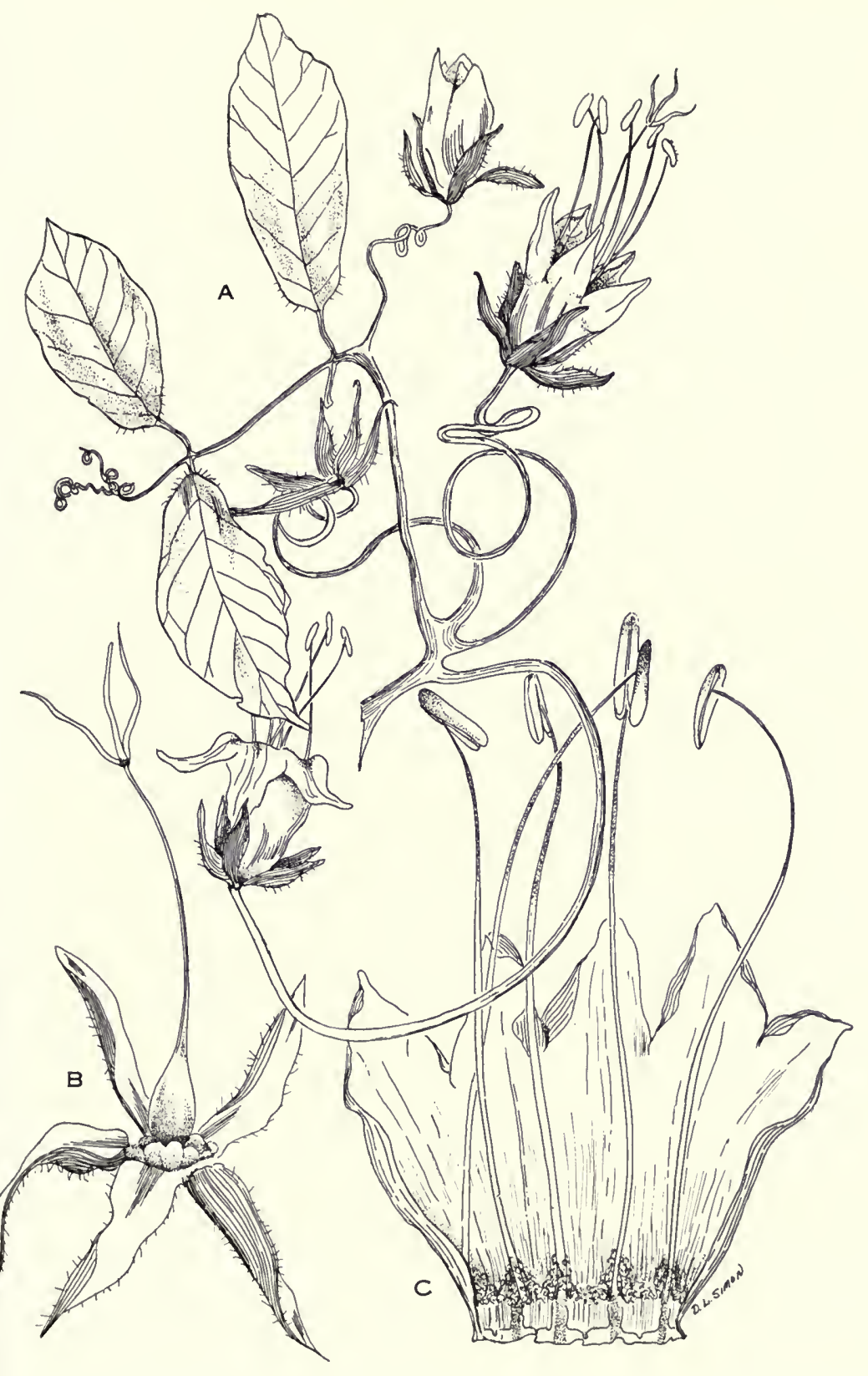

FIg. 15. Cobaea lutea. A, habit, 1/2 natural size; B, pistil, with disc and calyx, atural size; C, corolla opened to show stamens, natural size. 
Cobaea lutea Don, Edinburgh Phil. Journ. 10: 112. 1824. C. macrostema Pavón ex Don, l.c. as synonym; Hook. Bot. Mag. 66: pl. 3780. 1840. C. acuminata DC. ex Hook. l.c. C. macrostoma DC. Prodr. 9: 322. 1845. Rosenbergia macrostoma House, Muhlenbergia 4:24. 1908. Campana morada (Guatemala).

Usually in damp thickets but has been collected on dry hillsides, open, gravelly slopes, in hedges and as a weed in cornfields, 3002,666 m.; San Marcos; Quezaltenango; Retalhuleu; Escuintla; Sacatepéquez; Guatemala; Santa Rosa; Jalapa; Jutiapa; Chiquimula. Mexico (Hinton 11671), San Antonio, Dist. Montes de Oca, Gro.

A small or large vine, sometimes densely covering shrubs or small trees, the typical form glabrous almost throughout; leaflets thin when dry but somewhat succulent when fresh (fide Standley), essentially glabrous but of ten villous ciliate at base, short-petiolulate, oblong to obovate, sometimes pandurate, $3-8 \mathrm{~cm}$. long, acute to short-acuminate, mucronulate, rounded or subcordate at base, of ten unequal; flowers usually solitary but may be 2 or 3 on peduncles $15-25 \mathrm{~cm}$. long; sepals divided almost to base, $2-3.5 \mathrm{~cm}$. long, lanceolate or linear-lanceolate, usually long-attenuate, essentially glabrous but those of the typical form ciliate with long, scattered, slender hairs; corolla pale green or yellowish-green, rarely tinged with brown or light purple, $3.5-6 \mathrm{~cm}$. long, the lobes acuminate to long-acuminate, usually minutely puberulent outside; stamens very long-exserted, purplish; style long-exserted; capsule $3-5.5 \mathrm{~cm}$. long.

The specific name is inappropriate as the corolla is nearly always described by collectors as "pale green"; only one label of the 39 collections studied reads "yellowish-green."

C. lutea f. villosa (Standl.) Gibson, Fieldiana: Botany 31: 354 . 1968. C. villosa Standl. Contr. U. S. Nat. Herb. 17: 454. 1914. Ala de cucaracha and Granadina (El Salvador).

Differs from C. lutea only by villous nodes; sometimes also villous or puberulent on petioles.

Although it has not been reported from Guatemala, it may be expected there, as one collection, Padilla 415, was made in Ahuachapán, near the Guatemalan border.

C. lutea f. viorna (Standl.) Gibson. Fieldiana: Botany 31: 354. 1968. C. viorna Standl. Contr. U. S. Nat. Herb. 17: 453. 1914. Colchito and Rosanillo (Jutiapa). 
Differs from $C$. lutea only in the absence of long cilia on sepals and leaf bases.

Cobaea pachysepala Standl. Contr. U. S. Nat. Herb. 17: 456, t. 29. 1914.

Damp forests and thickets, 1,500-3,000 m. Guatemala; Sacatepéquez; Chimaltenango.

A small or large vine, the stems glabrous except villous at nodes; leaflets essentially glabrous, sometimes villous-ciliate, narrowly oblong to lance-oblong, 5-10 $\mathrm{cm}$. long, 2.3-3 cm. wide, acuminate, mucronate, rounded or sub-cordate at base, petiolules short-villous; flowers $1-3$ on peduncles $12-22 \mathrm{~cm}$. long; sepals divided almost to base, $1.5-3.8 \mathrm{~cm}$. long, thick and leathery, lanceolate, acuminate, puberulent outside near base, the typical form finely tomentulose only inside along margins; corolla pale green or yellowish-green, prominently nerved, narrowed rather abruptly near base, 5.5-6 cm. long, essentially glabrous but sparsely villous near base, the lobes rounded ovate, obtuse, $12-20 \mathrm{~mm}$. long, glabrous but minutely ciliate; stamens about equalling corolla or surpassing it by ca. $1 \mathrm{~cm}$., filaments villous to wooly, more densely so at base; style surpassing corolla by only $8-12 \mathrm{~mm}$., stigmas thick, $2.5-3 \mathrm{~mm}$. long; capsule $5-6.5 \mathrm{~cm}$. long.

C. pachysepala f. tomentulosa (Standl.) Gibson. Fieldiana: Botany 31: 354. 1968. C. tomentulosa Standl. Contr. U. S. Nat. Herb. 17: 457. 1914. Flor de campana (Quezaltenango).

Differs from $C$. pachysepala only in more dense vesture: the stems may be obscurely tomentulose to densely villous, the nodes often densely white-villous, the petiolules short-villous to wooly, the leaflets sparsely pubescent to villous beneath, especially along veins, the sepals usually densely tomentulose on the outside as well as along inside margins, and the corollas may have more scattered puberulence on the lobes.

Cobaea scandens Cav. Icon. Pl. 1: 11, t. 16, 1\%. 1791; Benth. in DC. Prodr. 9: 322. 1845; Brand in Engler, Pflanzenr. IV, 250: 24. 1907. Rosenbergia scandens House, Muhlenbergia 3: 23. 1908. Campana, campana morada (fide Standley), bejuca campana (Dept. Guatemala, fide Aguilar).

Cultivated at various places, 1,500-3,800 m.; cultivated specimens seen from Huehuetenango, San Marcos and Guatemala; of ten persisting in hedges (fide Standley). Mexico and western South America, Venezuela to northern Chile.

A large vine with only scattered pubescence on stem and petioles; mature leaflets usually $7-8 \mathrm{~cm}$. long, $3-3.5 \mathrm{~cm}$. wide but may attain 10 by $5 \mathrm{~cm}$., glabrous (rarely minutely ciliate), acuminate, the upper 2 pairs on short-petiolules, elliptic 
to obovate, oblique at base, the lower pair almost panduriform, usually auriculate, sessile or subsessile; flowers solitary on peduncles $15-22 \mathrm{~cm}$. long; calyx broadly campanulate, outer surface glaucous but minutely short-pubescent on the inside, the sepals united for more than one-half their length, $2.5-3.5 \mathrm{~cm}$. long, $2-3 \mathrm{~cm}$. wide, oval or suborbicular, rounded at apex, undulate, mucronate; corolla usually greenish-lavender or purplish or variously striped but may be green or greenishwhite, purplish inside, $5-6 \mathrm{~cm}$. long, the lobes orbicular to obovate, sometimes with sparse, minute puberulence on the outside; stamens exserted; style slightly exceeding or about equalling corolla tube; capsule 5-7 cm. long, seated on disc of deeply bilobate lobes.

Cobaea skutchii I. M. Johnston, Journ. Arn. Arb. 19:128. 1938.

Wet, mixed forests or thickets, 1,200-2,650 m.; Quezaltenango; Sacatepéquez; Escuintla.

A slender vine, almost entirely glabrous but may be sparsely and minutely villous at nodes; leaflets slender-petiolulate, membranaceous, glabrous, lanceoblong to oblong-ovate, usually 6-11 cm. long, acuminate, mucronate, truncate to subcordate at base, of ten unequal; flowers solitary on peduncles averaging $20 \mathrm{~cm}$. in length; sepals united for one-fourth to one-third their length, 1.3-1.6 cm. long, 0.8-1.1 cm. wide, glabrous, ovate, acuminate, mucronate; corolla pale green, ca. $2.5 \mathrm{~cm}$. long, the lobes obtuse or rounded, minutely puberulent on the outside; stamens shortly exserted (usually not more than $0.5 \mathrm{~cm}$.); style exserted by $1-2$ cm.; capsule ca. $4 \mathrm{~cm}$. long.

Cobaea steyermarkii Standl. Field Mus. Bot. 22: 271. 1940.

Known only from the type, San Marcos, Loma Corona, 9 miles northwest of El Porvenir, southwestern slopes of Volcán Tajumulco, 1,300-2,000 m., Steyermark 37759.

A very slender vine, essentially glabrous, the stems sparsely and minutely villous only at the nodes; leaflets thin, glabrous, slender-petiolulate, oblong-ovate to lance-oblong, 2.5-6 $\mathrm{cm}$. long, acute to acuminate, mucronate, truncate to subcordate at base, of ten unequal; flowers solitary on peduncles to $22 \mathrm{~cm}$. long, sepals divided almost to base, ca. $2 \mathrm{~cm}$. long, glabrous, linear-lanceolate, narrowly longacuminate, mucronate; corolla pale green at first, becoming yellow, ca. $2 \mathrm{~cm}$. long, the lobes broadly triangular, subobtuse, minutely puberulent on the outside; stamens long-exserted (fide Standley); style exserted, capsule $4.5 \mathrm{~cm}$. long.

As this type specimen is a unicate collection, dissection was not made. The small size of the corolla may be misleading, as the flower may not have been completely developed. If the stamens were longexserted as Standley says, they are now broken and gone. In other details, this collection is much like C. triflora.

Cobaea triflora Donn.-Smith, Bot. Gaz. 13:75. 1888. C. macrostoma var. triflora Brand, Pflanzenr. IV, 250: 26. 1907. Rosenbergia triflora House, Muhlenbergia 4: 25. 1908. 
Wet forests or thickets, Alta Verapaz and possibly Baja Verapaz, $900-1,650 \mathrm{~m}$.

A small or large vine, usually glabrous except for some minute pubescence on stems and petioles; leaflets thin, glabrous, slender-petiolulate, oblong-ovate to lance-oblong, 2.6-8 cm. long, acuminate, mucronate, somewhat narrowed to the truncate or subcordate and often oblique base; flowers 1-3 on peduncles 15-22 cm. long; sepals divided almost to base, $2-3 \mathrm{~cm}$. long, essentially glabrous, sometimes minutely villous at base and on margins, linear-lanceolate to lanceolate, longattenuate; corolla purplish-green, or pale yellow tinged with reddish-purple, 3-4 $\mathrm{cm}$. long, the lobes short, rounded to broadly triangular, minutely puberulent without; stamens shortly exserted, exceeding corolla by not more than $0.5 \mathrm{~cm}$.; style usually shortly exserted but may surpass corolla by $1-2 \mathrm{~cm}$.; capsule $4-5 \mathrm{~cm}$. long.

Although the specific name alludes to the fact that there are sometimes three flowers at a node, this character is variable; three flowers have been observed in the nodes of several collections of C. lutea and C. pachysepala and may occur in other species. The corollas of some specimens of $C$. lutea occasionally display purple or brownish tinges, but $C$. triflora is readily separated from $C$. lutea by its smaller corollas with short lobes, and the stamens only shortly exserted. The corolla lobes of $C$. pachysepala are similar in shape but the corolla tubes of $C$. triflora are much smaller, and the filaments of the stamens are never wooly near the apex as in C. pachysepala.

\section{LOESELIA L.}

Reference: Brand in Engler, Pflanzenr. IV, 250: 172-179. 1907.

Annuals or perennials, sometimes low shrubs; leaves sessile to short-petiolate, mostly alternate, occasionally sub-opposite, entire or dentate; flowers 1-3 in leaf axils or glomerate at ends of upper branches, subtended by imbricate bracts; calyx tubular to tubular-campanulate, slightly zygomorphic, the membranous sinuses hyaline, rupturing in age, the lobes herbaceous; corolla pale yellow, white, lavender or purple, salverform, bilabiate, the tube slender or gibbous, the lobes equalling or shorter than the tube; stamens glabrous, inserted at the same height just below the throat of the corolla, exserted; style exserted; ovary elliptic-ovoid, seated on a small disc; mature capsule ellipsoid to elliptic-obovoid, glabrous, enclosed in the accrescent calyx, about equalling the calyx tube, dehiscing loculicidally, each locule containing 1-several small, narrowly winged seeds.

Of the ten reported species, only three are known from Guatemala.

Bracts of inflorescence broadly ovate to reniform, ciliate with long, stiff bristles; corolla lobes pale yellow...................................

Bracts of inflorescence linear or lanceolate, usually dentate but not setose-ciliate; corolla lobes purple.

Inflorescence of several flowers in usually dense, long pedunculate, headlike clusters............................... glandulosa.

Inflorescence of only 1 or 2 flowers, almost sessile or very short pedicillate.

L. ramosissima. 
Loeselia ciliata L. Sp. Pl. 628. 1753. Benth. in DC. Prodr. 9: 319. 1845. L. aristata G. Don, Gen. Hist. Dichl. Pl. 4: 248. 1838. L. involucrata G. Don, l.c. L. ciliata var. echinophylla Brand in Engler, Pflanzenr. IV, 250: 178. 1907. Hoitzia aristata HBK. Nova Gen. \& Sp. 3: 164. 1818. H. loeselia Spreng. Syst. 1: 626. 1825. H. lupulina Hook. \& Arn. Bot. Beech. Voy. Suppl. 441. 1841. Canarios (Guatemala).

Usually in dry thickets or brushy slopes but occasionally in wet thickets, 75-1,800 m.; Baja Verapaz; Chimaltenango; Chiquimula; Escuintla; Guatemala; Jutiapa; Retalhuleu; Santa Rosa; Sacatepéquez; Zacapa. Mexico to Panama.

Annuals, usually much branched, erect (rarely prostrate), 0.45-1.2 m. tall (rarely to $2 \mathrm{~m}$.) the stems and branches slender and brittle, usually puberulent but may be glabrate, especially in age; leaves short-petiolate, oblong-ovate to broadly ovate, dentate, acute, truncate to attenuate at base, puberulous or glabrate; inflorescences usually long pedunculate, with few to many flowers, congested and bracteate, each flower subtended by a pair of papery, awned, glume-like bracteoles in addition to the 3 or more large, green bracts which are broadly ovate to reniform, sessile and clasping, and coarsely dentate, each tooth ending in a long, stiff, pale bristle; calyx lobes narrow, scarious and dentate, the terminal tooth usually prolonged; corolla ca. $1 \mathrm{~cm}$. long, pale yellow, or the tube white with straw-colored lobes, the margins of the lobes usually minutely tomentose; mature capsule ca. $4 \mathrm{~mm}$. long, each locule usually containing 1 (rarely 2) narrowly winged seed.

Loeselia glandulosa (Cav.) G. Don, Hist. Dichl. Pl. 4:248. 1837. L. glandulosa (Cav.) G. Don ssp. cervantesii (HBK.) Brand and var. nepetifolia (Cham. \& Schlecht.) Brand in Engler, Pflanzenr. IV, 250: 176-177. 1907. L. glandulosa (Cav.) G. Don ssp. conglomerata (HBK.) Brand and varieties hirsuta Brand and scabra (Mart. \& Gal.) Brand, l.c. L. nepetifolia G. Don, Gen. Syst. Dichl. Pl. 4:248. 1837. L. conglomerata G. Don, l.c. L. scabra Walpers, Rep. Bot. 6: 527. 1846-47. Hoitzia glandulosa Cav. Icon. 4: 45, t.367. 1797. H. cervantesii HBK. Nova Gen. \& Sp. 3: 128. 1819. H. conglomerata HBK. l.c. H. capitata Willd. in Roem. \& Schult. Syst. Veg. 4: 370. 1819. H. spicata Willd. l.c. H. nepetifolia Cham. \& Schlecht. Linnaea 6: 385. 1831. H. elata Hook. \& Arn. Bot. Beech. Voy. 441. 1841. H. scabra Mart. \& Gal. Bull. Acad. Brux. 12, 2: 274. 1845. Clarincillo silvestre (Huehuetenango); salvia virgen (Escuintla); orozuz amargo, salvia morada (Dept. Guatemala, fide Aguilar); Verbena (Chiapas, Mexico, fide Standley).

Usually in dry places, rocky, bushy hillsides and slopes, along roadsides, in pine-oak forests; occasionally in Cupressus groves and 
damp thickets, 350-2,950 meters; Alta Verapaz; Baja Verapaz; Chimaltenango; Chiquimula; Escuintla; Guatemala; Huehuetenango; Jalapa; Jutiapa; El Quiché; Sacatepéquez; Santa Rosa; Sololá; Zacapa. A heterogeneous species extending from southern Arizona through Mexico and Central America; Colombia and Venezuela.

Annuals, but of ten suffrutescent, usually $40-80 \mathrm{~cm}$. tall, occasionally only 15-20 cm. tall, the stems of ten much branched, slender, brittle, usually glandularpuberulent, occasionally glabrate, rarely eglandular; leaves short-petiolate, lanceolate to broadly ovate, acute to acuminate, sharply serrate, contracted at base and decurrent, usually pubescent but may be glabrate; flowers sessile or subsessile, usually in dense, headlike clusters, these few to many-flowered, on short or much elongated peduncles, the bracts linear to lanceolate, appressed, usually coarsely dentate, often glandular; calyx lobes narrow, dentate, aristate, usually puberulent; corolla pink, blue, lavender or purple, 1-2 cm. long, glabrous, the lobes about equalling the tube; mature capsule $2-3.5 \mathrm{~mm}$. long, each locule containing 3 flat, narrowly winged seeds; the seeds very sticky when wetted.

Loeselia glandulosa sens. lat. is a most interesting genetic complex. For instance, it was possible to readily separate all of the material in the species into two groups - those with corollas only $8-10 \mathrm{~mm}$. long, and those with corollas $15-20 \mathrm{~mm}$. long. It was also observed that the shorter corollas are often sharply constricted above the base of the tube, and that the peduncles of plants with large corollas tend to be longer and considerably farther apart on the stems than those with short corollas. However, none of these characters is constant; plants with small corollas sometimes have internodal distances of $5-8 \mathrm{~cm}$., very short peduncles, and the corolla tubes are not always constricted at the base. Leaf shape and pubescence also vary, occasionally an eglandular form is seen, and a few plants, all from Huehuetenango (Skutch 1930, Standley 65651 and 82092 and Van Hook 1), were observed to have bracts which, although short ciliate and strigose, lack dentation or serration. All of the varieties separated by Brand appear to be only variously pubescent forms, with the single exception of his var. ramosissima. This is Loeselia ramosissima (Mart. \& Gal.) Walpers, incorrectly reduced by Brand to varietal status.

Loeselia ramosissima (Mart. \& Gal.) Walp. Repert. Bot. 6: 526. 1846-47. L. glandulosa var. ramosissima Brand in Engler, Pflanzenr. IV, 250: 177. 1907. Hoitzia ramosissima Mart. \& Gal. Bull. Acad. Brux. 12(2): 273. 1845.

Usually in dry places, along roads in oak or oak-pine forests or on open slopes, occasionally a weed in cornfields, 1,600-2,800 m.; Huehuetenango; Quezaltenango (fide Standley); El Quiché. Western and southern Mexico. 
Annuals, usually branched from the base, erect, low, 8-30 cm. tall, the stems glandular-pilose; leaves short-petiolate, lanceolate or ovate, acute, serrate, usually pubescent (rarely glabrate), the lower leaves soon withering; flowers solitary or geminate, short-pedicillate or almost sessile, the bracts lanceolate or linear-lanceolate, dentate, unequally trilobate (the two opposite lateral lobes in no way equalling the terminal lobe); calyx lobes narrow, scarious, usually dentate; corolla violet or purple, $7-10 \mathrm{~mm}$. long, glabrous, the lobes about equalling the tube; mature capsule 2-3 mm. long, each locule containing only one plump, broadly winged seed.

Although reduced by Brand to varietal status under L. glandulosa, this species, well represented by numerous collections from Mexico and Guatemala, may be separated at a glance from L. glandulosa by the quite different appearance of the long, narrow, flowering branches. Further, the obvious enlargment of the two lateral lobes of the bracts does not occur in L. glandulosa, and L. ramosissima produces only one broadly winged seed in each locule, whereas three narrowly winged seeds are usually found in each locule of $L$. glandulosa.

\section{LENNOAEGAE}

\section{DoRothy N. GiBson}

REFERENCES: O. Drude in Engler \& Prantl, Pflanzenf. IV(1): 1215. 1891. P. A. Rydberg, Lennoaceae, N. Amer. Fl. 29: 19-20. 1914.

Small parasitic herbs, without chlorophyll, the stems fleshy, the leaves reduced to small scales; inflorescences cymose-paniculate, cymose-thyrsoid, spicate, or with flowers arranged on a peltate disk; flowers small, perfect; sepals 5-10, linear, distinct or nearly so; corolla gamopetalous, tubular or narrowly funnelf orm or salverform, 5-8-lobate; stamens 5-10, usually the same number as and alternate with the corolla lobes, the filaments almost entirely adnate to the corolla; anthers 2-celled, introrse, dehiscent by longitudinal slits; gynoecium of 6-14 wholly united carpels, the ovary divided by false dorsal partitions into twice as many cells, these uniovulate; style simple, the stigma capitate or peltate, crenate; ovules anatropous, almost horizontal; fruit drupaceous-capsular, finally irregularly circumscissile, containing 12-28 one-seeded nutlets; seeds with endosperm, the embryo globose.

Three genera, confined to the extreme southwestern United States, western and southern Mexico, and Guatemala. Only one genus is known to be represented south of Mexico.

\section{LENNOA Lexarza}

Low, succulent parasitic herbs, glabrous or somewhat pubescent, the stems simple or branched, bearing numerous more or less dentate bracts; inflorescence cymose-thyrsoid, the flowers densely crowded, bracteate; sepals 5-8, distinct almost to the base, pubescent or puberulent, linear; corolla funnelf orm to salverform, the limb plicate, the 8 lobes emarginate, the tube ventricose at the base, persistent; stamens 8 , in 2 whorls, included, the linear filaments adnate to the corolla for most of their length, anther cells ellipsoid, coherent at the apex, divergent below; ovary 8 -carpellate, with 16 locules in a ring, the 22 ovules horizontal, anatropous; fruit somewhat drupaceous. 


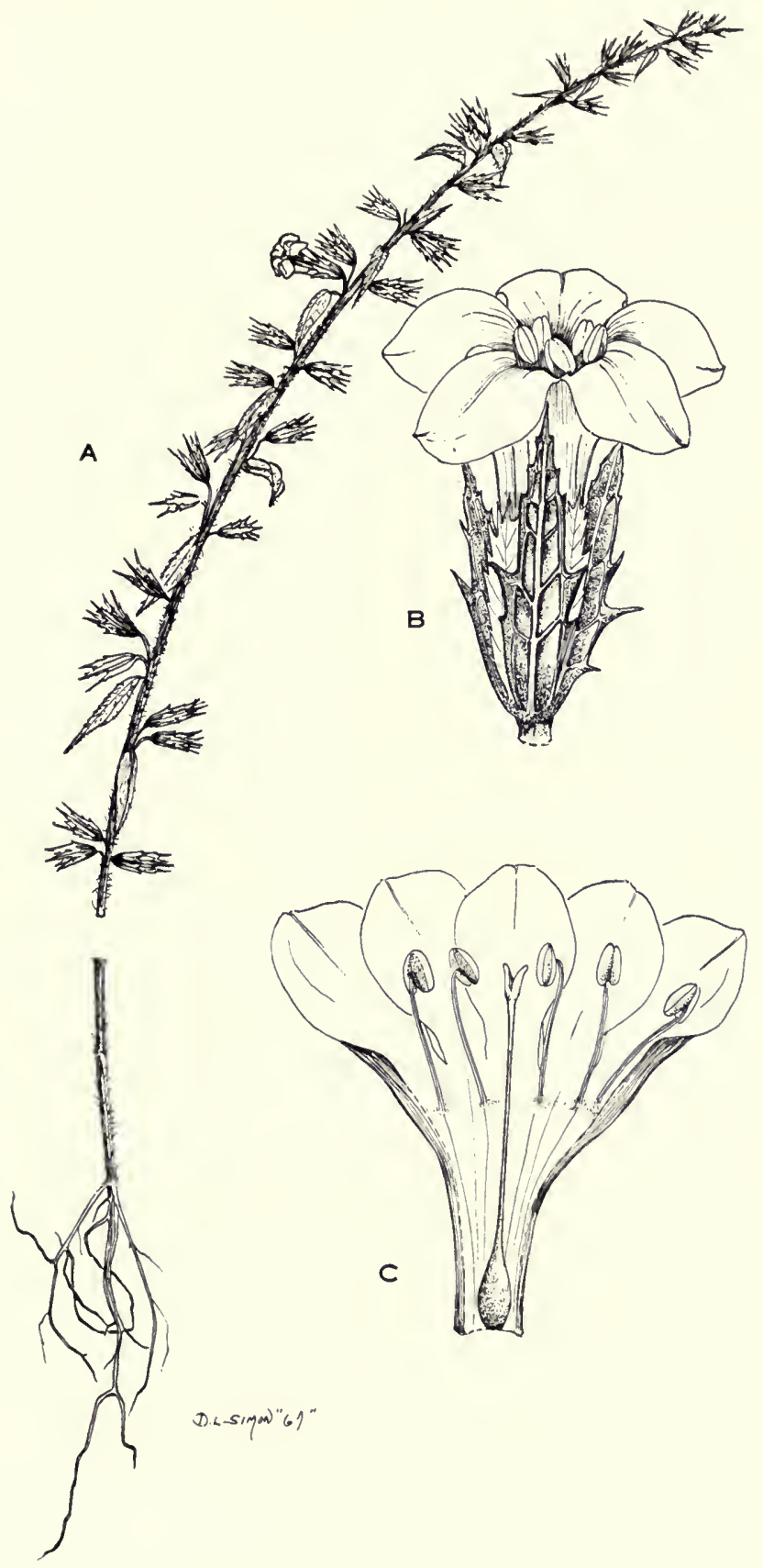

FIG. 16. Loeselia ramosissima. A, habit, natural size; B, flower with bracts, $\times 5$; C, corolla opened to show stamens and pistil, $\times 5$. 


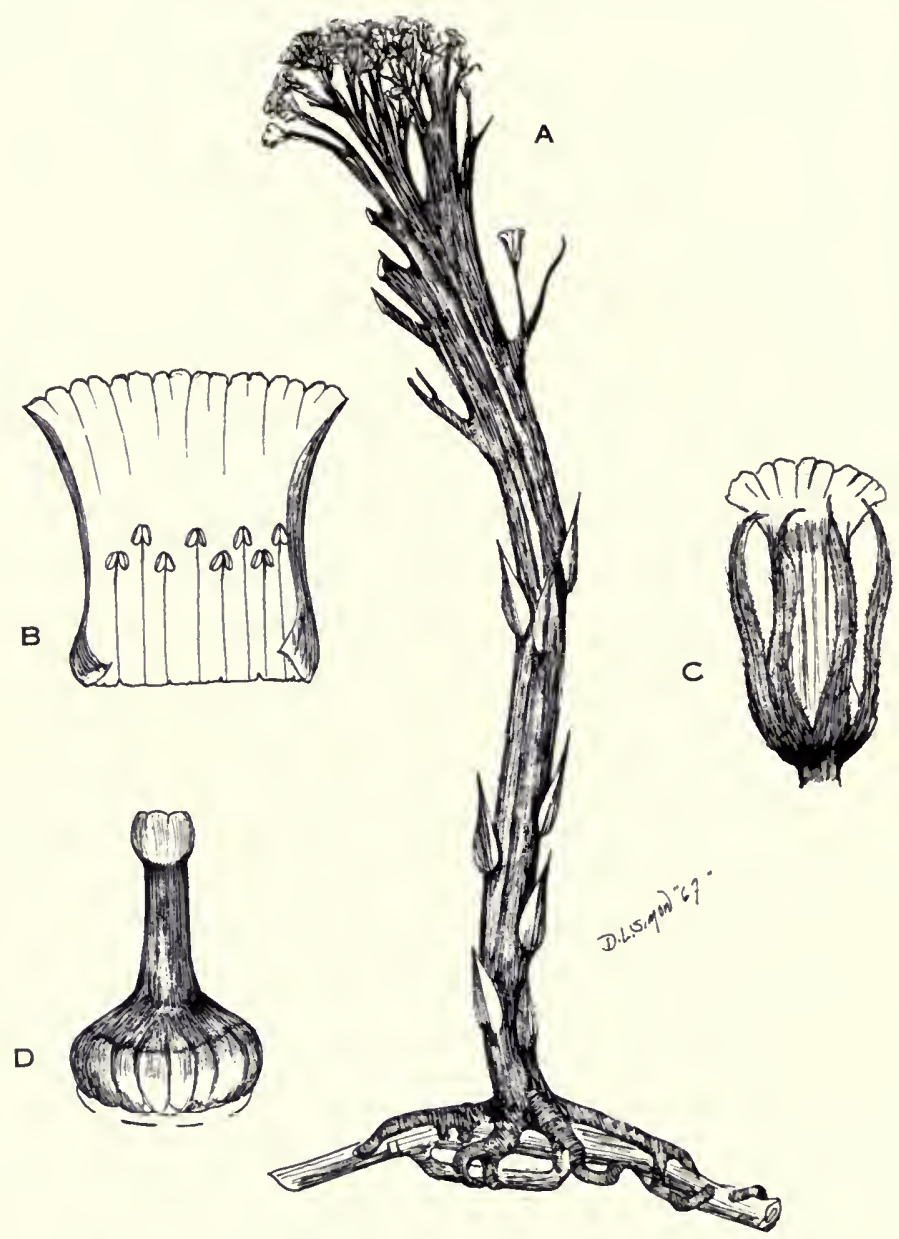

FIG. 17. Lennoa madreporoides. A, habit of plant, natural size; B, corolla opened to show stamens, $\times 5$; C, flower, $\times 5$; D, pistil, $\times 10$.

Two species or perhaps one species with two varieties, one confined to Mexico, one extending southward.

Lennoa madreporoides Lexarza in La Llave \& Lex. Nov. Veg. Descr. 1: 13. 1824. L. madrepoides Steud. Nom. Bot. ed. 2. 2: 22. 1841. L. madreporoides subsp. Australia Steyerm. Acta Bot. Venez. 3: 230. 1969 .

Dry banks, especially in cinders, 300 meters or less; Zacapa; El Progreso. Mexico. Reported from Colombia. 


\section{HYDROLEA L.}

ReFerence: Brand in Engler, Pflanzenr. IV, 251: 174-185. 1913.

Annuals or perennials from taproots, usually erect, sometimes decumbent, herbaceous to partly woody, usually glandular-pubescent, sometimes spiny in leafaxils; leaves alternate, entire, elliptical-lanceolate to obovate; flowers usually few in lateral and/or terminal cymes; calyx divided to base with lobes overlapping at base, persistent, accrescent; corolla usually blue, sometimes white, broadly campanulate, usually exceeding the calyx; stamens included, inserted on tube, partly adnate at base, filaments dilated at base, anthers sagittate; styles 2 (rarely 3 or 5 ), elongating, with clavate-capitate stigmas; ovary superior, globose to nearly elliptic, bilocular, with two fleshy placentae containing numerous ovules; capsule globose to nearly elliptic, dehiscing irregularly, containing numerous, minute seeds.

A variable genus of several species, ranging from the southern United States through Mexico, Central and South America, the East and West Indies, and in Asia and Africa, it is represented in Guatemala by only one species.

Hydrolea spinosa L. Sp. Pl. ed. 2: 328. 1762; Aubl. Hist. Pl. Guian. 1: 281. 1775; HBK. Nova Gen. \& Sp. 3: 98. 1818; Edwards' Bot. Reg. 7: t. 566. 1821; Choisy in Mém. Soc. Phys. Genève 6: 110 . 1833 and in DC. Prodr. 10: 181. 1846; Brand in Engler, Pflanzenr. IV, 251: 180. 1913. H. cervantesii Brand and var. maior Brand, l.c. 184. H. trigyna Swartz, Nov. Gen. \& Sp. Ind. Occ. 54. 1788. Sagonea palustris Aubl. Hist. Pl. Guiana 1:285. 1775. Campanula americana hirsuta Houst. ex Swartz, Nov. Gen. \& Sp. Ind. Occ. 54. 1788. Reichelia guianensis Spreng. Syst. 1: 940. 1825. R. palustris Billberg ex Beurl. in Vet. Acad. Handl. Stockholm 141. 1856. Espina de agua (Dept. Guatemala).

In marshes, wet thickets, meadows, and in sand along streams, rivers and lakes, 45-1,600 m.; Baja Verapaz; Chimaltenango; Chiquimula; Escuintla; Guatemala; Isabal; Jalapa; Jutiapa; Petén; El Progreso; El Quiché; Retalhuleu; San Marcos; Santa Rosa; Sacatepéquez; Zacapa. Southwestern United States through Mexico to Panama.

Annuals or perennials, usually erect, simple or much branched, $15-130 \mathrm{~cm}$. tall, the stems and branches pilose and glandular; leaves subsessile to short petiolate, variable, usually elliptic to elliptic-ovate, occasionally narrowly elliptic, rarely obovate, averaging $2-12 \mathrm{~cm}$. long; flowers usually short-pedunculate, few in axillary and/or terminal cymes, of ten congested; sepals linear-lanceolate to lanceolate, acute, 5-7 mm. long, glandular-pilose; corolla open-campanulate, pale blue to purplish, 7-12 mm. across, 5-12 mm. long; stamens less than or surpassing or about equalling the corolla, adnate near base of tube, filaments dilated at base; ovary ovoid to globose, largely glabrous but minutely glandular near top; styles glandular at base, elongating; mature capsule 4-5 mm. long, ovoid to globose; seeds numerous, minute, light brown, longitudinally ridged. 


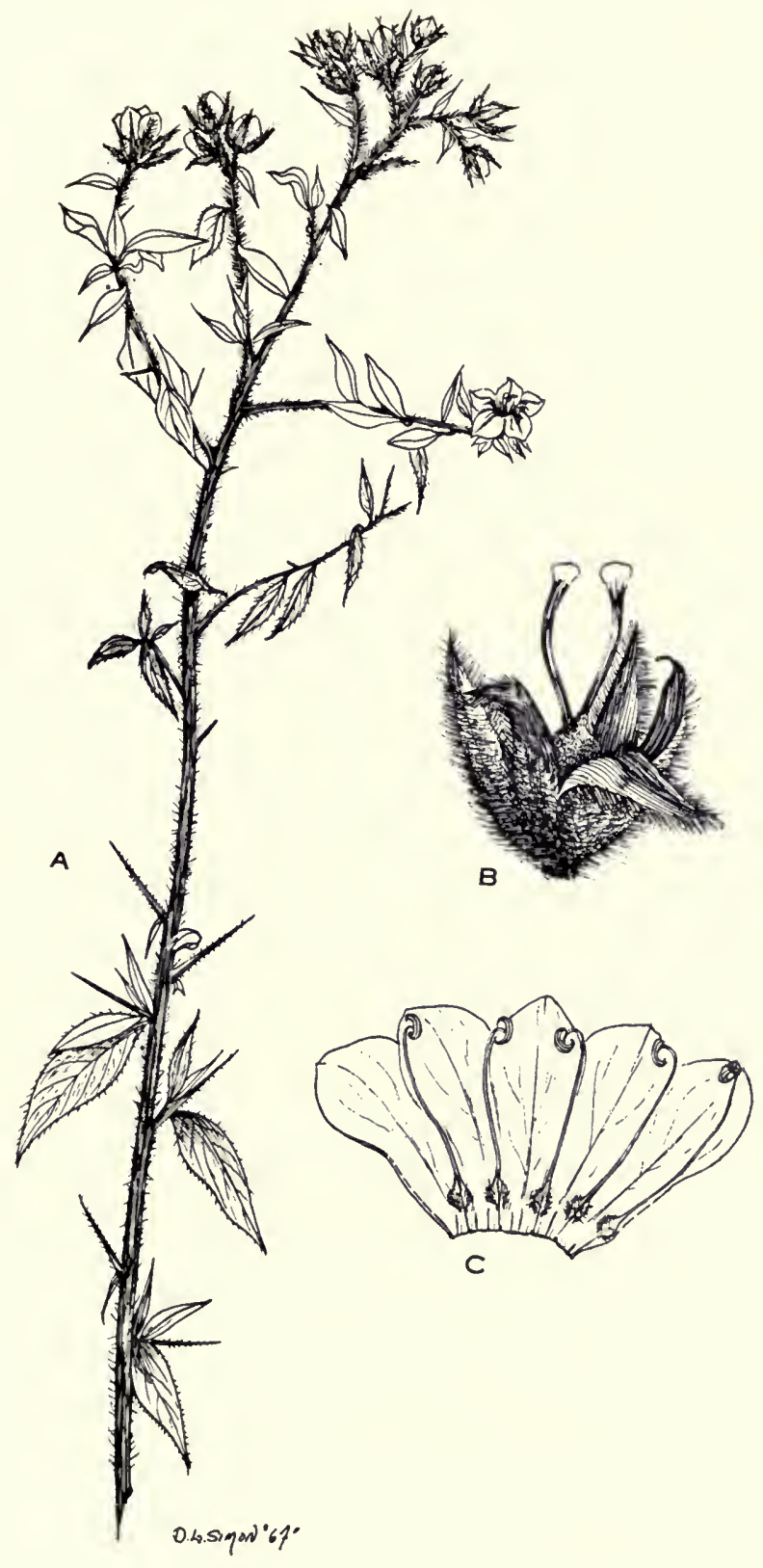

FIG. 18. Hydrolea spinosa. A, habit, $1 / 2$ natural size; $\mathrm{B}$, fruiting calyx, $\times 3$; C, corolla opened to show stamens, $\times 2$. 
Brand, in his description of $H$. cervantesii, stated, "Species basi staminum a ceteris speciebus generis valde diversa." However, several dissections of material cited by him revealed no appreciable or constant differences.

\section{NAMA L.}

ReFerences: Brand in Engler, Pflanzenr. IV, 251: 142. 1913; Hitchcock, A Taxonomic Study of the Genus Nama, I and II, Am. Journ. Bot. 20: 415-430 and 518-534. 1933.

Erect to prostrate, simple or branched, herbaceous to partly woody, pubescent, of ten glandular annuals or perennials from slender taproots; leaves mostly alternate and entire, rarely dentate; flowers borne singly or in pairs in axils of upper leaves or several in reduced lateral or terminal cymes; calyx divided nearly to base, the lobes linear-lanceolate to linear-spatulate, subequal, accrescent; corolla white to purple, sometimes partly puberulent, tubular to funnelform, exceeding the calyx; stamens usually included, all basally adnate and unequally inserted on the corolla tube or may be unequal in length, filaments usually glabrous, their bases dilated or sometimes appendaged; styles 2, elongating, usually free but sometimes partially united, with small capitate stigmas; ovary superior to semi-inferior, usually somewhat puberulent, unilocular but appearing bilocular due to the ingrowing parietal placentae; mature capsule usually ovoid to oblong but may be globose, cartilaginous, dehiscing loculicidally or septicidally, containing numerous brown, variously pitted, reticulate, or smooth seeds.

A variable genus ranging from the western United States through Mexico, Central America, the West Indies, western South America and the Hawaiian Islands.

Plants erect.

Leaves linear-spatulate to oblong-elliptic. . .

N. dichotomum.

Leaves oblong-lanceolate, obovate, or nearly ovate.

Calyx lobes broadly spatulate, strigose-ciliate.

N. dichotomum var chasmogamum. Calyx lobes linear to linear-spatulate, greyish-hirsute.

Plants ascending, trailing, or prostrate.

Plants ascending or trailing; leaves obovate to elliptic-lanceolate or elliptic, petioles not winged ...................... hirsutum.

Plants prostrate; leaves broadly ovate to spatulate, narrowed to winged petioles.................................. jamaicense.

Nama dichotomum (R. \& P.) Choisy, Mém. Soc. Phys. Genève 6: 113. 1833; Gray, Proc. Am. Acad. 5: 338. 1861; Brand in Engler, Pflanzenr. IV, 251: 150. 1913. Hydrolea dichotoma Ruiz \& Pav. Fl. Peruv. 3:22, t. 244, fig. b. 1802. N. tetrandra Pavón ex Choisy, Mém. Soc. Phys. Genève 6: 113. 1833, in synon. N. stricta Phil. Fl. Atac. 37. 1860. Marilaunidium strictum (Phil.) Kuntze, Rev. Gen. Pl. 2, 
434. 1891. N. dichotomum subsp. eu-dichotomum Brand in Engler: Pflanzenr. IV, 251: 151. 1913 (in part). N. dichotomum subsp. eudichotomum f. stricta (Phil.) Brand, l.c. 151, fig. 28. N. dichotomum subsp. eu-dichotomum f. amplifolia Brand, l.c. N. dichotomum var. angustifolium Gray, Proc. Am. Acad. 8:284. 1870. N. angustifolium (Gray) A. Nels., Coult. and Nels. New Man. Rocky Mt. Bot. 410. 1909. N. dichotomum subsp. angustifolium (Gray) Brand in Engler, Pflanzenr. IV, 251: 151. 1913. N. dichotomum $\beta$ pauciflora Choisy ex Gray, Proc. Am. Acad. 8: 284. 1870. Conanthus angustifolius (Gray) Heller, Bull. Torr. Bot. Club 24: 479. 1897. Marilaunidium dichotomum (R. \& P.) Kuntze, Rev. Gen. Pl. 2: 434. 1891. Marilaunidium tenue Woot. \& Standl. Contr. U. S. Nat. Herb. 16: 162. 1913. N. dichotomum var. amplifolium (Brand) Hitchc. Am. Journ. Bot. 20: 530. 1933.

A common weed in gardens, fields and pastures, on open hillsides, sandy stream banks and in open oak forests, 1,600-4,000 m.; Chimaltenango; Guatemala; Huehuetenango; Quezaltenango; El Quiché; Sacatapéquez. Mexico.

Annual, slender, erect, simple or more or less dichotomously branched herbs, 4-30 cm. tall, hirsute and glandular; leaves linear-spatulate to oblong-elliptic, 4$30 \mathrm{~mm}$. long, 1-10 mm. wide, tapering to short petioles; flowers usually in pairs in leaf axils, sessile or on short pedicels; calyx lobes linear-spatulate, $2-5 \mathrm{~mm}$. in flower, to $10 \mathrm{~mm}$. in fruit, hirsute and ciliate; corolla white to pale blue or lavender, or white with blue or lavender lines, narrowly campanulate, to $5 \mathrm{~mm}$. long; stamens unequally placed about $1 \mathrm{~mm}$. from base of corolla, the glabrous filaments widened slightly just above the adnate base and with free margins along the adnate portions; styles to $2 \mathrm{~mm}$. long; capsules more or less puberulent, ovoid to oblong, containing $20-60$ brown, minutely reticulate seeds.

\section{N. dichotomum var. chasmogamum Brand in Engler, Pflan-} zenr. IV, 251: 151. 1913.

More robust and more profusely branched than N. dichotomum; leaves usually larger and broader, to $40 \mathrm{~mm}$. long and $15 \mathrm{~mm}$. wide, oblong-lanceolate to nearly ovate; flowers more numerous, $1-3$ at nodes and in axillary and terminal lax cymes, pedicels longer, to 6 $\mathrm{mm}$.; cilia of calyx lobes usually longer; styles often longer, to $6 \mathrm{~mm}$.

N. dichotomum var. pueblense (Rob. \& Greenm.) Macbride, Contr. Gray Herb. 49: 45. 1917. N. pueblense Rob. \& Greenm. Proc. Am. Acad. 32: 39. 1896.

Leaves oblong-ovate to obovate; calyx and leaves greyish-hirsute.

The only collection seen is from Huehuetenango, Williams, $M_{o-}$ lina \& Williams 22352, apparently a new record for Guatemala. 


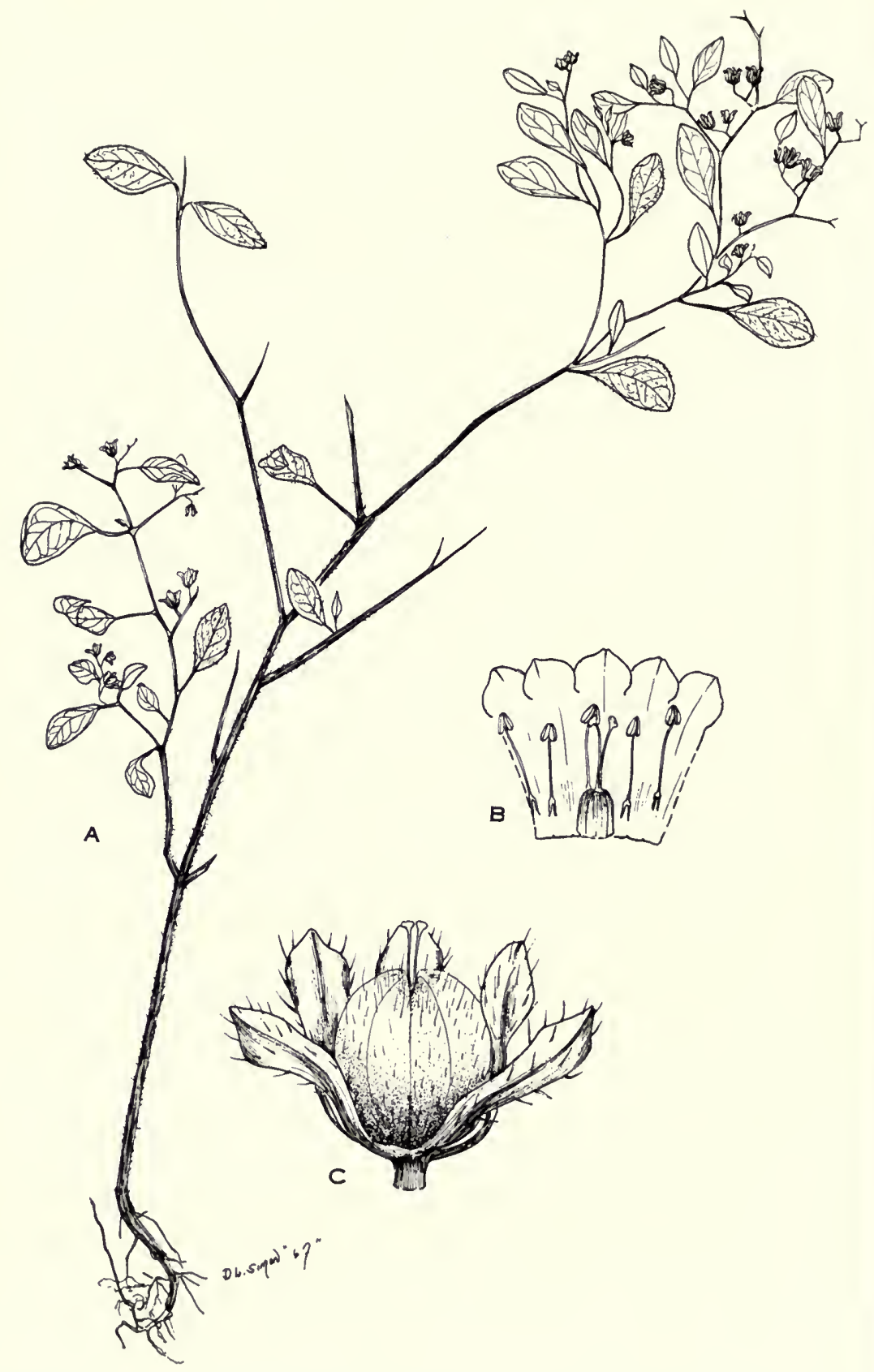

FIG. 19. Nama dichotomum var. chasmogamum. A, habit of plant, 1/2 natural size; $B$, corolla opened to show stamens and pistil, $\times 5$; C, capsule with calyx, $\times 5$. 
Nama hirsutum Mart. \& Gal. Bull. Acad. Sci. Brux. 12(2): 277. 1845; Gray, Proc. Am. Acad. 5: 339. 1861; Brand in Engler, Pflanzenr. IV, 251: 148. 1913. Marilaunidium hirsutum (Mart. \& Gal.) Kuntze, Rev. Gen. Pl. 2: 434. 1891.

Open slopes, 1,800-3,200 m.; Chimaltenango; Quezaltenango; Sololá and Totonicapán. Mexico.

A slender perennial, hispid to strigose-hirsute, ascending or with trailing, somewhat woody older branches, $8-60 \mathrm{~cm}$. long; leaves obovate to elliptic-lanceolate or elliptic, $0.8-3 \mathrm{~cm}$. long, $0.5-1.2 \mathrm{~cm}$. broad, with short petioles on older branches and extreme forms, but may attain $8 \mathrm{~cm}$. by $3 \mathrm{~cm}$. on new shoots and stems, with petioles 1-2 cm. long; flowers in pairs or 3-10 in lax cymes; calyx lobes narrowly oblanceolate-spatulate to spatulate, $3-6 \mathrm{~mm}$. long in flower, $4-8 \mathrm{~mm}$. in fruit, hirsute and ciliate; corolla white to pale lilac or white veined with purple, funnelshaped, 6-11 mm. Iong; stamens unequally placed 1-2 mm. from base of corolla, free filaments flattened, much widened directly above point of insertion and throughout adnate bases, except with margins of adnate bases free; styles $2-5 \mathrm{~mm}$. long; mature capsules more or less puberulent, especially near base of styles, usually ovoid but occasionally nearly globose, containing less than 20 (usually $4-12$ ) granular, minutely alveolate, brown seeds.

It should be noted that all of the Guatemalan collections studied which had been previously identified as N. prostratum Brand (Johnston 1915, Skutch 597, Standley 80138a, Steyermark 47212, Williams et al. 22571 and 23029) are now determined to be $N$. hirsutum, despite minor differences. Although the leaves are smaller and all the styles (with the single exception of Skutch 597) are about $2 \mathrm{~mm}$. shorter than those of the typical N. hirsutum, several dissections disclosed the same number of seeds (never more than 12) and showed the nature of the adnate portions of the filaments to match exactly those of N. hirsutum. Brand's description of N. prostratum leaves much to be desired, and as I was unable to examine the type fragment, Ehrenberg 326 (P) from Mexico, my knowledge of this species is limited to Hitcheock's description and his drawing of the opened corolla (Am. Journ. Bot. 20: t. 27, fig. 28, 1933). Our specimens in no way resemble that drawing. The creation of a new variety does not seem justifiable at this point.

Nama jamaicense L. Syst. Nat. ed. 10, 2: 950. 1759; Choisy in DC. Prodr. 10: 182. 1846; Gray in Hemsl. Biol. Cent. Am. Bot. 2: 365. 1882; Brand in Engler, Pflanzenr. IV, 251:155. 1913. N. jamaicense var. gracile Brand, l.c. 156 . N. reclinata villosa P. Browne, Civ. \& Nat. Hist. Jam. 185, t. 18, fig. 2, 1756, fide Brand. Hydrolea amaicense Roenschel, Nom. ed. 3, 76. 1797. H. decurrens Moc. ex Choisy in DC. Prodr. 10: 181. 1846. Conanthus jamaicensis (L.) 
Heller, Cat. N. Am. Pl. 6. 1898. Marilaunidium jamaicense (L.) Kuntze, Rev. Gen. Pl. 2: 434, t. 27, fig. 19. 1891. Colchita (Jutiapa); paletoria and parietaria (Huehuetenango) fide Steyermark.

A common weed of fields, clearings, dry hillsides, wet banks and sand-bars, 85-2,000 m.; Alta Verapaz; Chimaltenango; Guatemala; Huehuetenango; Isabal; Jalapa; Jutiapa; Petén; Quezaltenango; Sacatepéquez; Santa Rosa. Mexico, West Indies, South America.

A slender annual, prostrate, strigose-hirsute, with branches $10-50 \mathrm{~cm}$. long; leaves broadly ovate to spatulate or broadly obovate-spatulate, $1-8 \mathrm{~cm}$. long, $0.5-3.5 \mathrm{~cm}$. broad, narrowed to distinct, winged petioles a fifth as long as the blades; flowers few, solitary or in 2's, 3's or 5's in leaf axils, nearly sessile or on pedicels to $1.5 \mathrm{~cm}$. long; calyx lobes usually linear and acute, but may be narrowly spatulate, from ca. $5 \mathrm{~mm}$. long in flower to $12 \mathrm{~mm}$. long in fruit, of ten clasping the ovary rather tightly; corolla white, sometimes tinged with lavender, almost tubular, 6-7 mm. long; stamens unequally inserted on tube 1-2 $\mathrm{mm}$. from base of corolla, filaments terete above, but flattened and greatly expanded, ca. $1 \mathrm{~mm}$. above point of insertion, the adnate portion expanded, with free margins; styles 1.5-2 mm. long, usually distinct but sometimes united $1 / 3$ to $1 / 2$ their length; capsule usually puberulent near base of styles, elongated, containing 50-70 light brown, minutely alveolate seeds.

Nama jamaicense closely resembles and intergrades with $N$. biflorum Choisy of Mexico. However, I agree with Hitchcock that both species should be maintained, as $N$. biflorum exhibits several differing characters which appear to be constant, i.e., smaller leaves, larger corollas (to $11 \mathrm{~mm}$. long), and the flowers are borne on longer pedicels $(1.5-4 \mathrm{~cm}$.$) .$

\section{PHACELIA Juss.}

References: A. Brand in Engler, Pflanzenr. IV, 251: 60-130. 1913; Lincoln Constance, A Revision of Phacelia subgenus Cosmanthus, Contr. Gray Herb. 168: 16. 1949.

Herbaceous, branching, erect to decumbent annuals or perennials from taproots or creeping rootstocks, usually pubescent and of ten glandular; cauline leaves usually alternate, entire, lobed, pinnatifid or pinnately dissected; basal leaves often rosulate, flowers few to numerous in usually helicoid, raceme-like terminal cymes, long pedunculate to sessile; corolla blue, purple, pale lilac or white, campanulate; calyx divided nearly to base, persistent, of ten accrescent; stamens usually exserted, all adnate to and equidistant from the base of the corolla tube, a pair of scales or glands adnate to tube sometimes present at base of each filament; style bifid; ovary unilocular with 2 linear placentae adherent to walls; capsule ovoid to globose, loculicidally dehiscent, containing 2 to many, minutely rugose-aerolate seeds. 


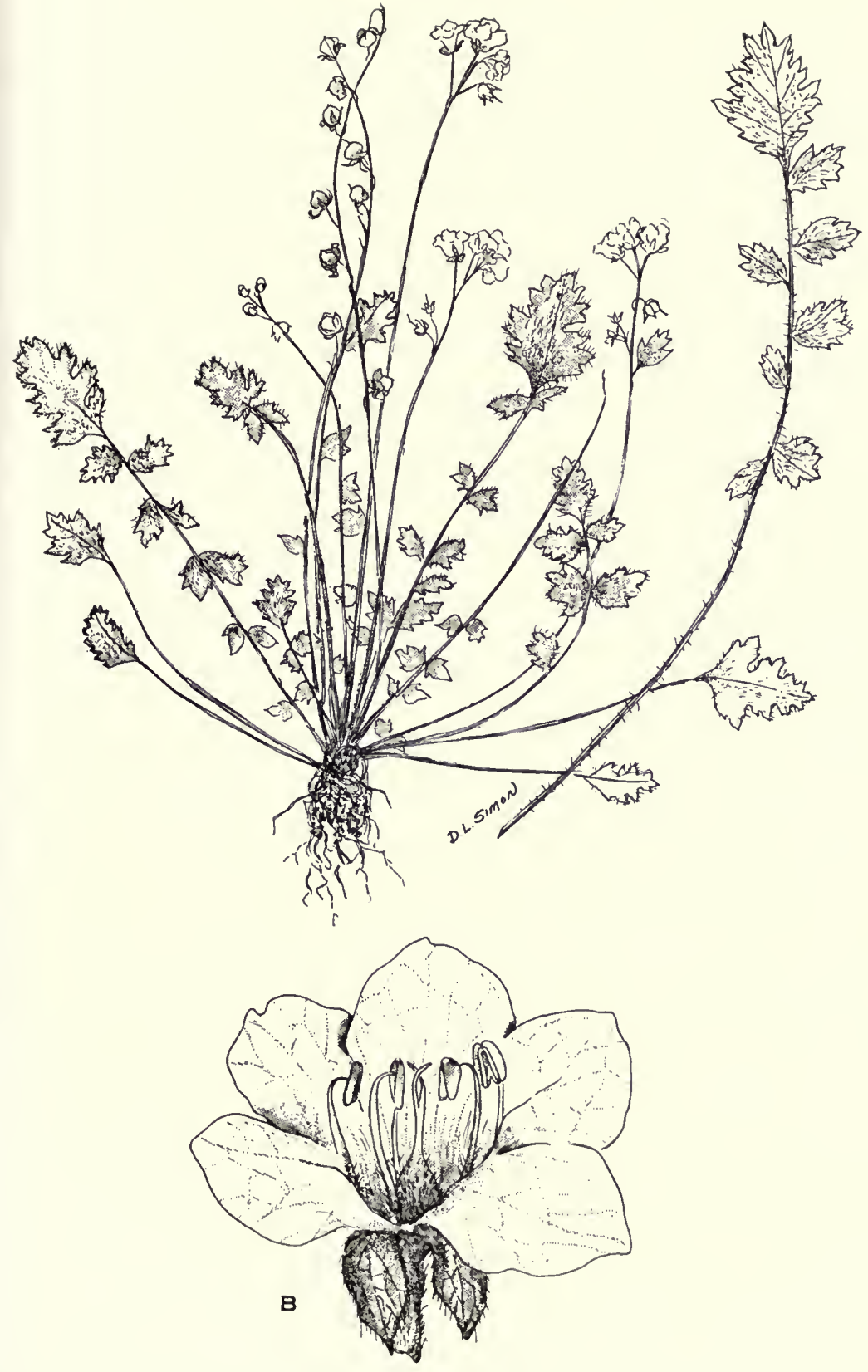

FIG. 20. Phacelia platycarpa. A, habit of plant, $1 / 2$ natural size; $B$, flower, $\times 5$. 
A variable American genus, widely distributed, especially throughout the western United States, it is well represented in Mexico and in the Andes, but only one species is known from Guatemala and none has been reported from other Central American countries. The subgenus Cosmanthus, to which our single species belongs, contains 14 species; ours is apparently limited to the highlands of Mexico and Guatemala.

Phacelia platycarpa (Cav.) Spreng. Syst. 1: 584. 1825. Convolvulus platycarpos Cav. Icon. 5: 155, t. 482. 1799. Polemonium pimpinelloides Willd. ex Roem. \& Schult. Syst. 4:793.1819. P.achillaeifolium Willd. l.c. Eutoca pimpinelloides Spreng. Syst. 1: 569. 1825. E. mexicana Benth., Trans. Linn. Soc. 17:277. 1834. E. andrieuxii A. DC. Prodr. 9: 294. 1845. E. gracilis Mart. \& Gal. Bull. Acad. Brux. 12(2): 276. 1845. E. ortgiesiana Heer ex Regel, Gartenfl. 10: 309, t. 33\%. 1861. Cosmanthus mexicanus A. DC. Prodr. 9: 297. 1845. Nemophila ortgiesiana Roezl ex Regel, Gartenfl. 10: 309. 1861. Phacelia pimpinelloides A. Gray, Proc. Am. Acad. 10: 321. 1875. P. pubescens Peter in Engler \& Prantl, Pflanzenf. 4, 3a: 64. 1893. P. patuliflora var. mexicana Brand in Engler, Pflanzenr. IV, 251: 66. 1913.

In dry or moist meadows and thickets, and along roadsides, cornfields and rivers, 1,500-3,700 m.; Huehuetenango; Quezaltenango; Sololá; Chimaletenango. A variable species, ranging throughout montane Mexico to Guatemala.

Perennial from a stout taproot, 5-40 $\mathrm{cm}$. tall, the branches decumbent to weakly ascending from a basal rosette, pubescent; basal leaves petiolate, linear to oblanceolate or oblong, $3-30 \mathrm{~cm}$. long, $0.8-6 \mathrm{~cm}$. broad, pinnate with $4-8$ pairs of oblong to obovate, entire to pinnatified leaflets, or the terminal one confluent; cauline leaves like the basal but reduced upward, toothed or pinnate, usually somewhat strigulose to hirsute on both surfaces but especially so underneath along midvein; inflorescence a loose cyme of few to many flowers on pedicels $5-30 \mathrm{~mm}$. long; calyx lobes linear-lanceolate to ovate-lanceolate, 3-6 mm. long, unequal, acute, more or less puberulent; corolla pink to pale blue or white tinged with lavender, rotate-campanulate, 6-10 $\mathrm{mm}$. long, $7-15 \mathrm{~mm}$. broad, the lobes rounded, somewhat pilose on the back, puberulent gland flaps free at tips; stamens about equalling or less than the corolla, filaments villous at base and for at least one-half their length; ovary at least partly hirsute, containing 4-10 ovules on each placenta, style hirsute on lower half; mature capsule globose, $3-6 \mathrm{~mm}$. in diameter, containing $9-15$ brown, trigonate, rugose-aerolate seeds.

\section{WIGANDIA HBK.}

REFERENCE: Brand in Engler, Pflanzenr. IV, 251: 134. 1913. 
Large, suffruticose to arborescent perennials, variously pubescent (including stinging hairs) and glandular throughout; leaves alternate, of ten quite large but variable in size from 5-60 cm. long, 3-42 cm. broad, coriaceous, ovate, obtuse to sub-acute at apex, cordate to truncate at base, irregularly twice-dentate; flowers few to many, sessile to sub-sessile, of ten appearing densely spicate, in scorpioid, terminal cymes or panicles; caly $x$ persistent, divided nearly to base, the lobes subequal, linear-lanceolate to lanceolate, acute, accrescent, hispid-hirsute to tomentose and ciliate; corolla greenish-white, yellow, or lavender to purple, usually exeeding the calyx, often partly pilose to tomentose without, the lobes rounded; stamens exserted, partly adnate to the base of the corolla tube, filaments at least partly pubescent, anthers linear-oblong, dorsifixed; styles 2, elongated, with capitate-clavate, depressed stigmas; ovary superior, oblong, pubescent, unilocular, with 2 laminiform placentae, the transverse portions of each meeting in the center, with numerous ovules borne chiefly along their revolute edges; mature capsule ovate-oblong, pubescent, dehiscing loculicidally or septicidally, and containing numerous minute, reticulate-rugose, brown seeds.

A widely distributed, weedy, variable genus, ranging from Mexico throughout Central America, to Argentina.

Plants setose-hispid, at least on stems, petioles, and midveins of leaves. .W. urens. Plants without setae on stems, petioles, or leaves. W. urens var. caracasana.

Wigandia urens (R.\& P.) HBK. Nova Gen. \& Sp. 3: 127.1819; Choisy in DC. Prodr. 10: 184. 1846, incorrectly as "W. urens (R. \& P.) Choisy." W. kunthii Choisy, Mém. Soc. Phys. Genève 6: 116. 1833 and in DC. Prodr. 10: 184. 1846. W. peruviana W. Miller, Bailey Cyclop. Am. Hort. 1975. 1902. W. urens var. eu-kunthii Brand, Pflanzenr. IV, 251: 137. 1913. Hydrolea urens Ruiz \& Pav. Fl. Peruv. 3: 21. t. 243. 1802. Ernstamra urens (R. \& P.) O. Ktze. Rev. Gen. Pl. 2:434. 1891. Chocón (Sacatepéquez); la Aurora (Guatemala); chichicaste (Guatemala, Honduras, El Salvador); quemadora (Mexico); ortiga (Mexico and Costa Rica).

Frequent along roadsides, in thickets, damp meadows or sandy fields, dry slopes, oak and oak-pine forests, and in waste places, 70 3,000 m.; Huehuetenango; San Marcos; Quezaltenango; Sacatepéquez; Chimaltenango; Guatemala; Alta Verapaz; Santa Rosa. Mexico to Panama and in Peru and Ecuador.

Suffruticose plants, occasionally becoming small trees to $5 \mathrm{~m}$. tall, usually densely sordid with hispid to bristly-hirsute, sometimes glandular-viscid, and often stinging hairs; leaves alternate, $5-60 \mathrm{~cm}$. long, 3-42 cm. wide, ovate, obtuse to subacute at apex, cordate to truncate at base, irregularly biserrate, appressed pilose on upper surface and usually white-tomentose underneath, with bristles at least on midvein and petiole; flowers sessile to subsessile in dense, scorpioid terminal cymes or panicles; calyx persistent, the lobes subequal, acutely linear-lanceolate, setosehispid to tomentose and hispid-ciliate, about equalling or slightly surpassing the 


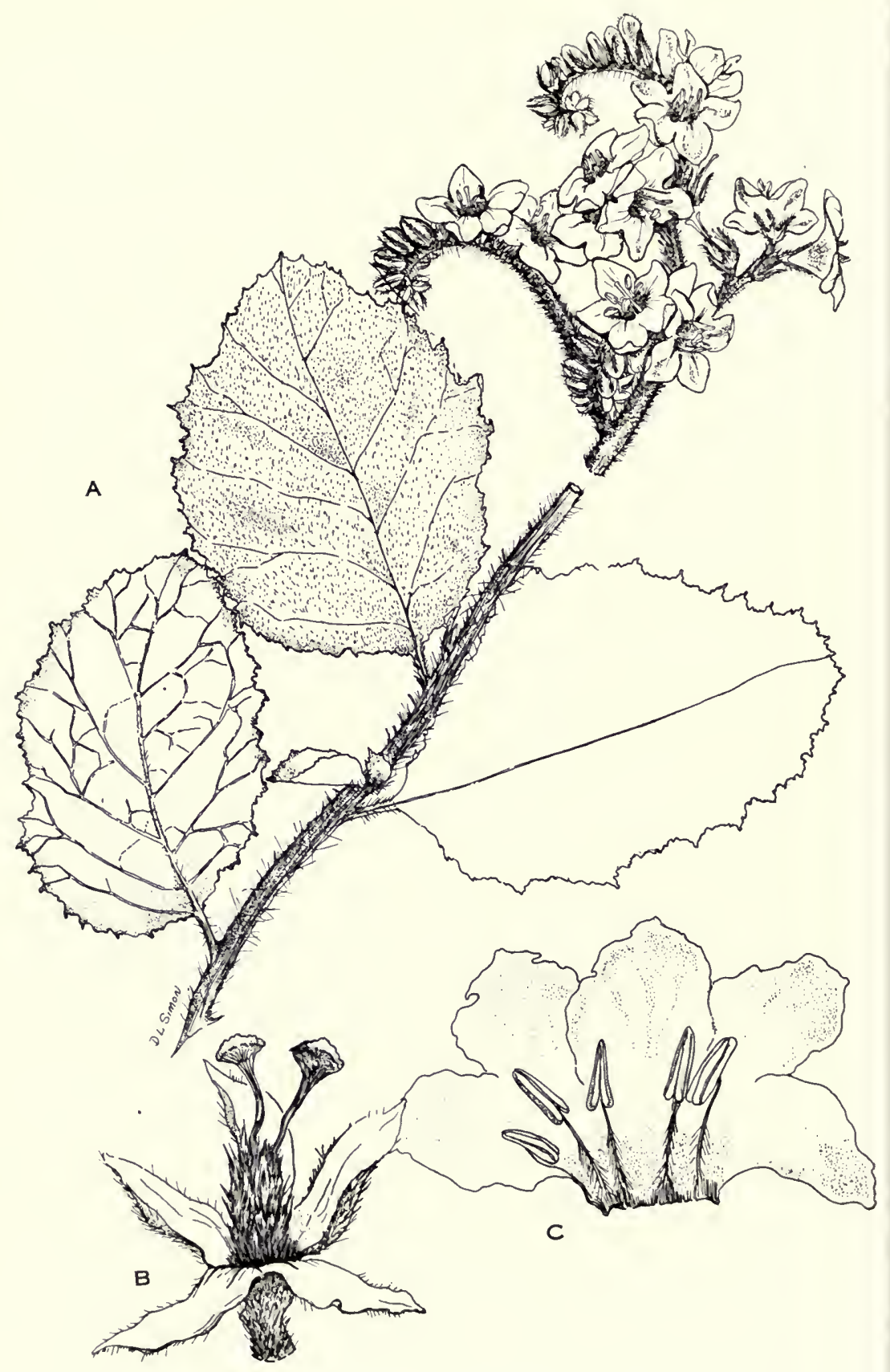

FIG. 21. Wigandia urens. A, flowering branch, $1 / 2$ natural size; $B$, pistil, with calyx, $\times 3 ; \mathrm{C}$, corolla opened to show stamens, $\times 2$. 
mature capsule; corolla pale violet to purple, lighter in throat, silky pilose to tomentose without, to $20 \mathrm{~mm}$. long, equalling or slightly exceeding the calyx; stamens included, subequal, filaments retrorsely hispid from base to half or nearly twothirds their length, basally adnate to corolla tube; styles at anthesis $6-10 \mathrm{~mm}$. long, of ten becoming 10-15 mm. long in maturity, pilose for more than one-third their length; stigmas clavate-capitate; ovary ovoid-oblong, silky to hispid-hirsute; mature capsule oblong-conical, partly hoary to hispid-hirsute; seeds numerous, minute, reticulate-rugose, brown.

A widepsread and variable species, especially in vesture.

One collection from Panama, Davidson 972, has leaves with the soft appearance of var. caracasana, but with stems and calyces covered with long, soft, shaggy hairs and only a few scattered hard bristles. This type of vesture was also seen on peduncles and calyces of a few specimens of the var. caracasana from Mexico and Costa Rica.

W. urens var. caracasana (HBK.) Gibson. Fieldiana: Botany 31: 353. 1968.

W. caracasana HBK. Nova Gen. \& Sp. 3: 128. 1819. W. macrophylla Cham. \& Schlecht. Linnaea 6: 382. 1831. W. scorpioides Choisy, Ann. Sc. Nat. Sér. 1, 30: 249. 1833. W. caracasana var. macrophylla (Cham. \& Schlect.) Brand, Pflanzenr. IV, 251: 136. 1913. W. caracasana var. calycina Brand, l.c. W. caracasana var. viscosa (Donn.-Sm.) Macbride, Contr. Gray Herb. New ser. 49: 42. 1917. W. kunthii var. intermedia Brand, Pflanzenr. IV, 251: 137. 1913. W. kunthii var. viscosa (Donn.-Sm.) Brand, l.c. Chocón, chichicaste (Guatemala, El Salvador and Honduras); tabacón (Jalapa), tabaquillo (Costa Rica).

Mexico to Costa Rica; Colombia and Venezuela.

Differs from $W$. urens only in its lack of bristles on leaves and stems. The leaves usually appear velvety, without bristles on the midvein. The calyx lobes and capsule, however, may be hispid to bristly-hirsute, as in $W$. urens.

\title{
BORAGINACEAE. Borage Family
}

\author{
DoRothy N. GiBson
}

Annual or perennial herbs, shrubs, trees, or woody vines, usually with scabrous, setose, or hispid indument, rarely tomentose or glabrous; stipules none; leaves alternate or rarely opposite or verticillate, entire or dentate; inflorescence normally dichotomous-cymose but sometimes greatly modified, the flowers often secund, sessile or pedicellate, arranged on helicoid or scorpioid cymes; flowers small or large, 
usually blue, purple, or white, sometimes yellow, regular, perfect or rarely by abortion polygamous; calyx usually persistent and often accrescent in fruit, the tube when present usually campanulate, the teeth, lobes, or segments usually 5 , rarely fewer or 6-8, slightly imbricate or of ten open in bud; corolla gamopetalous, funnelform, tubular, salverform, campanulate, or subrotate, the limb usually 5-lobate, imbricate or rarely contorted; stamens as many as the corolla lobes and alternate with them, inserted in the tube or throat of the corolla, equal or slightly unequal; filaments short or long, sometimes dilated at the base, the anthers ovate, oblong, or linear, obtuse or appendaged, dorsifixed above the base, shallowly or deeply bilobate at the base, the cells distinct, parallel, introrsely or laterally dehiscent by longitudinal slits; disk annular, entire or 5-lobate, usually inconspicuous and continuous with the ovary, or obsolete; ovary superior, sessile and confluent at the base with the disk, usually composed of 2 carpels, entire or 4-lobate, the cells 1-2ovulate; style in the lobate ovary inserted between the lobes, in the entire ovary terminal, filiform or short, entire or 1-2-bifid or rarely divided into 2 styles; stigma entire and capitate, or bilobate, or annular; ovules erect, oblique, or subhorizontal; fruit drupaceous, with a hard 2-4-celled endocarp, or the fruit separating into 2-4 nutlets, or by abortion 1-celled and consisting of a single nutlet, the exocarp fleshy and juicy, or when the fruit composed of 4 or by abortion fewer nutlets, these usually hard and distinct, indehiscent, often echinate or variously roughened; seeds straight or incurved; endosperm carnose, abundant, scant, or none; embryo straight or curved; cotyledons flat, plano-convex, or thick and fleshy, the radicle short.

About 90 genera, widely distributed in both hemispheres, frequently weedy. Excepting two, which are native to Europe but frequently grown in Guatemalan gardens (Borago officinalis L. and Myosotis scorpioides L.) and an Asian species (Cynoglossum amabile Stapf \& Drumm., which is becoming naturalized in Guatemala), only the following are known from Central America.

It is often difficult to delimit certain genera, especially if fruiting material is not available. Some shrubby species of Heliotropium are much like Tournefortia; flowering material of Hackelia, Cynoglossum, and Myosotis is often confused in herbaria; monographic work would be most helpful.

Style inserted between the usually 4 distinct lobes of the ovary; plants herbaceous.

Nutlets echinate; corolla blue.

Nutlets erect, the spines of at least some of them always more than $1 \mathrm{~mm}$. long (1.5-4 mm.); gynobase pyramidal; upper cauline leaves more or less narrowed to the base..................................

Nutlets widely spreading, the spines less than $1 \mathrm{~mm}$. long; gynobase depressed; upper cauline leaves rounded at the base and more or less

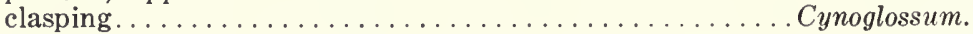

Nutlets not echinate; corolla white or yellow.

Stamens exserted. Macromeria.

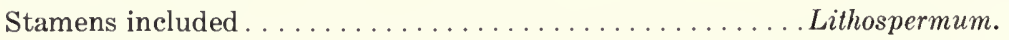

Style apical on the ovary; plants trees, shrubs, or vines, except in Heliotropium.

Style twice bifid. Cordia. 
Style entire or only bifid.

Fruits dry, separating into $2-4$ bony nutlets; herbs or low shrubs.

Fruits drupaceous; shrubs, trees, or vines.

Heliotropium.

Leaves in fascicles Rochefortia.

Leaves not in fascicles.

Stigma annular or conic, topped by a sterile, usually bifid appendage.

Stigmas 2, truncate, capitate, or clavate.

Tournefortia.

Calyx closed in bud, valvate, irregularly $2-5$ lobate at anthesis.

Bourreria.

Calyx not closed in bud, the 5 lobes distinct, of ten imbricate.

Ehretia.

\section{BOURRERIA P. Browne}

References: P. Browne, Civ. Nat. Hist. Jamaica 168. 1756; M. Gürke in Engler \& Prantl, Pflanzenf. IV, 3a: 86-87. 1897.

Trees or shrubs, glabrous or pubescent, of ten tomentulose; leaves mostly alternate, usually petiolate, smooth or scabrous, the margins entire, dentate or serrate; inflorescences terminal, of dichotomous, corymbose cymes, usually many-flowered, the flowers white, small or large, of ten fragrant; calyx in bud globose or ovoid, closed, at anthesis cleft into 2-5 valvate teeth or lobes; corolla 5-lobate, the lobes imbricate in bud, the tube short or elongated, the throat of ten dilated, the lobes broad and spreading; stamens 5, attached to the tube, included or exserted, the filaments glabrous or villous near the base, the anthers ovate or oblong, $2-3 \mathrm{~mm}$. long; ovary at anthesis 4-celled, the style terminal, bifid, the stigmas truncate, capitate or clavate; ovules attached laterally above or below the middle; fruit drupaceous, subglobose or ovoid, separating into 4 hard, of ten triquetrous nutlets, the central column 4-parted; seeds attached laterally, the endosperm carnose; cotyledons flat.

Perhaps 15 or 20 species, from Mexico to the West Indies and northern South America. The generic name has been written Beureria, but the name Bourreria is conserved.

Filaments of stamens villous near base.

Upper surface of leaf blades smooth; calyx glabrous outside........ B. huanita.

Upper surface of leaf blades scabrous; calyx pubescent to velvety or tomentose

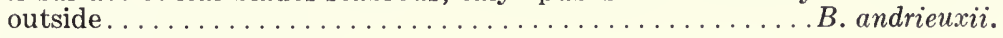
Filaments of stamens glabrous.

Lower surface of leaf blades glabrous, or puberulent only along veins.

B. oxyphylla.

Lower surface of leaf blades densely and finely grayish-pubescent.....B. mollis.

Bourreria andrieuxii (A. DC.) Hemsl. Biol. Cent. Am. Bot. 2: 369. 1882. Ehretia andrieuxii DC. Prodr. 9: 510. 1845. Crematomia andrieuxii Miers, Contr. Bot. 2: 254. 1869. 
At 800-900 meters, Huehuetenango. Mexico, Honduras, Nicaragua.

Shrubs or small trees, to $4.5 \mathrm{~m}$. tall; leaves on stout petioles $1.5-3 \mathrm{~cm}$. long, the blades coriaceous, with 7-9 pairs of lateral veins, ovate to broadly ovate, 6-12 cm. long, 3-9 cm. wide, acute to almost rounded at apex, acute to subtruncate at base, entire, upper surface scabrous, lower surface finely and sof tly pubescent; inflorescence cymose, terminal, ca. $8 \mathrm{~cm}$. long and wide, many-flowered, the stems and peduncles puberulent to velvety or tomentose, flowers nearly sessile or on pedicels 1-4 mm. long (rarely to $10 \mathrm{~mm}$. long); calyx campanulate, of ten somewhat contracted at base, $4-5 \mathrm{~mm}$. long, the 5 lobes lanceolate, acute, about as long as the tube, sparsely or densely pubescent, of ten velvety outside, white tomentose within; corolla white, sometimes pinkish in age, $1-1.5 \mathrm{~cm}$. long, the limb $1-1.5 \mathrm{~cm}$. broad, the rounded lobes ca. $6 \mathrm{~mm}$. long, spreading; stamens exserted, filaments villous near base, anthers $2 \mathrm{~mm}$. long; fruits broadly ovoid, pointed, $7 \mathrm{~mm}$. long, $5 \mathrm{~mm}$. broad (perhaps immature).

The single collection from Guatemala, Steyermark 51402, superficially resembles $B$. pulchra Millsp. (Yucatan) but the leaf surfaces of $B$. pulchra are never scabrid; its calyces are 5-6 mm. long, glabrous outside, and its anthers $3 \mathrm{~mm}$. long. It has been confused with Ehretia latifolia A. DC.

Bourreria huanita (Llave \& Lex.) Hemsl. Biol. Cent. Am. Bot. 2: 370. 1882. Morelosia huanita Llave \& Lex., Nov. Veg. Descr. 1: 1. 1824. Ehretia formosa A. DC. Prodr. 9:510. 1845. B. grandiflora Bertol. Fl. Guat. 410. 1840 (type said to be from Escuintla). B. formosa Hemsl. Diagn. Pl. Nov. 34. 1879. Esquinsucha, esquinsuchil (Guatemala); oreja de león (Quezaltenango).

Damp forest, sea level to $2,100 \mathrm{~m}$.; often planted for ornament; Alta Verapaz; El Quiché; Guatemala; Izabal; Jutiapa; Quezaltenango; Sacatepéquez. Southern Mexico; Honduras; El Salvador; Costa Rica.

Trees, essentially glabrous throughout; leaves on petioles usually 1-3 cm. long, the blades glabrous or sometimes with scattered short hairs on costae and petioles, membranaceous, usually obovate to elliptic-oblong, rarely ovate, mostly $6-12 \mathrm{~cm}$ long, 3-8 cm. wide, obtuse to rounded or acuminate at the apex, broadly rounded to acute and sometimes oblique at the base, margins entire, lateral nerves 7-9 pairs; cymes usually large, ca. $8 \mathrm{~cm}$. long and as broad, usually many-flowered, the flowers sessile or on pedicels 1-6 $\mathrm{mm}$. long; calyx campanulate, 6-8 $\mathrm{mm}$. long, apiculate in bud, glabrous outside, white with short tomentum within, the 5 lobes unequal, 1-2 mm. long, triangular, acute or subacute, usually rupturing in to 3 unequal segments in fruit; corolla white, ca. $2 \mathrm{~cm}$. long, the tube only slightly exceeding the calyx, the limb 2-3 cm. broad, glabrous outside but sometimes with a tuft of appressed sericeous hairs within the lobes near the apex; stamens long-exserted, the filaments villous near the base; fruits large, ovoid, when dry ca. $12 \mathrm{~mm}$. long and $17 \mathrm{~mm}$. broad. 


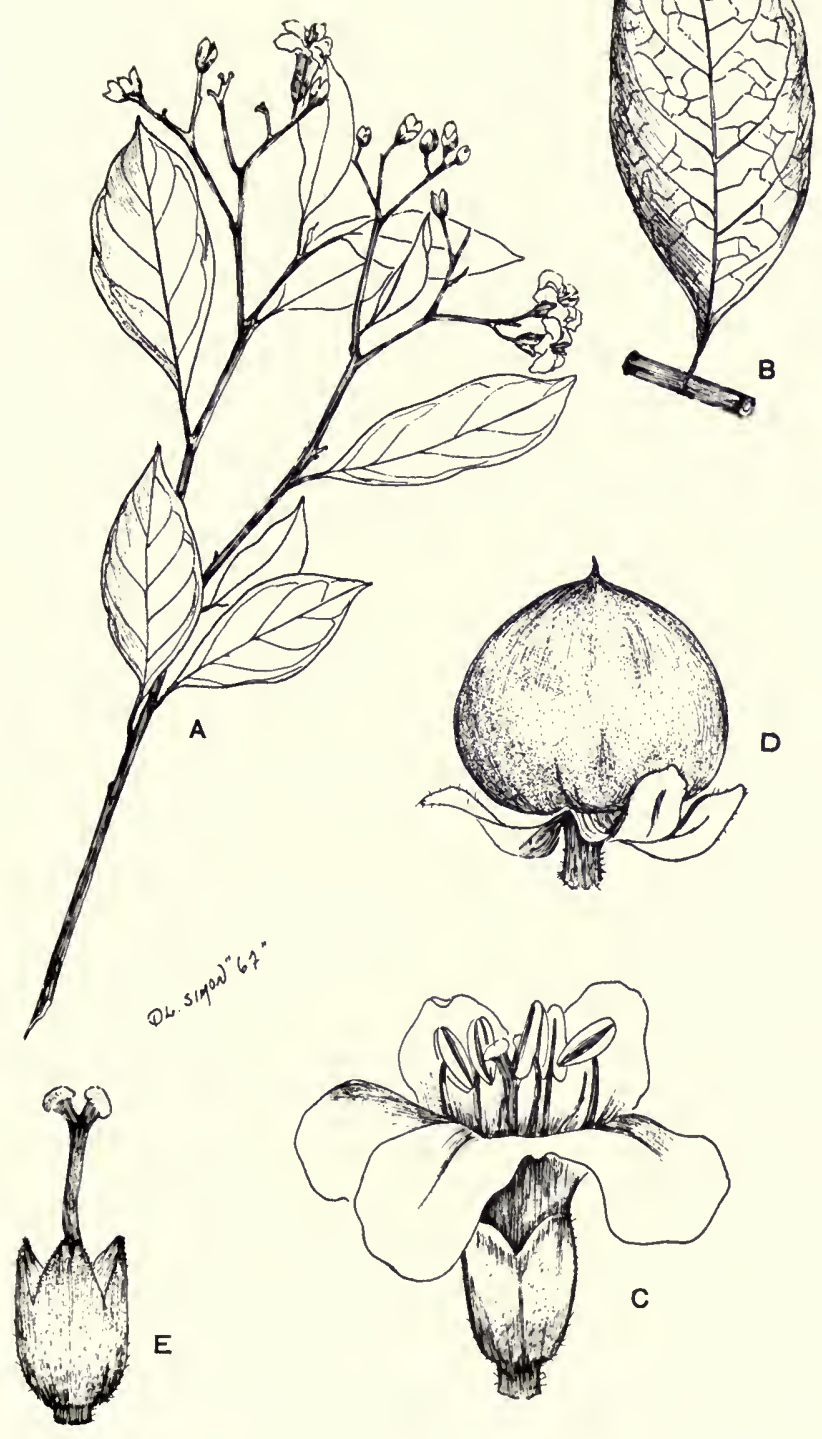

FIG. 22. Bourreria oxyphylla. A, habit of plant, $1 / 2$ natural size; B, a larger leaf, $1 / 2$ natural size; $\mathrm{C}$, flower, $\times 3$; E, calyx, style, and stigmas, $\times 3$. 
Bourreria mollis Standl. Trop Woods 8: 5. 1926. Opay; roble; black fiddlewood.

Known only from British Honduras, at or a little above sea level.

Trees, the branches densely velutinous-pubescent; leaves on petioles $8-15 \mathrm{~mm}$. long, the blades elliptic or ovate-elliptic, $3-8.5 \mathrm{~cm}$. long, $1.5-5.5 \mathrm{~cm}$. wide, acute or obtuse, obtuse or broadly cuneate at the base, glabrate above, densely grayishpubescent to velutinous beneath; cymes few-many-flowered, pedunculate, $4 \mathrm{~cm}$. broad, the flowers short-pedicellate, peduncles and pedicels densely tomentose, calyx narrowly campanulate, 5-6 $\mathrm{mm}$. long, densely tomentulose, the lobes usually 3 , triangular or rounded-ovate, obtuse or subacute, shorter than the tube; corolla white, the tube slightly longer than the calyx, the lobes $5 \mathrm{~mm}$. long, rounded at the apex, puberulent outside; stamens exserted, the filaments glabrous, an thers $2 \mathrm{~mm}$ long. Fruits unknown.

Bourreria oxyphylla Standl. Trop. Woods 16: 40. 1928 (type from British Honduras, Aitken 4). B. wagneri Standl. in Yuncker, Field Mus. Bot. 9: 328. 1940 (as Beureria). Laurel, roble, sac-bayeck, wild craboo (British Honduras).

Damp or wet, mixed forest, $800 \mathrm{~m}$. or less; Petén. Chiapas, Mexico; British Honduras, Honduras.

Trees, to $18 \mathrm{~m}$., the trunk almost a meter in diameter, sometimes fluted, the young branchlets sparsely hirtellous or glabrate; leaves on slender, somewhat pubescent or glabrate petioles, 8-12 $\mathrm{mm}$. long, the blades oblong-elliptic or oblong, $4-11.5 \mathrm{~cm}$. long, $2.5-5.5 \mathrm{~cm}$. wide, acute or short-acuminate, acute or obtuse at the base, firm-membranous, with 6-8 pairs of lateral nerves, entire, essentially glabrous, sometimes puberulent beneath with scattered hairs along the nerves; cymes many-flowered, to $7.5 \mathrm{~cm}$. long and broad, pedunculate, grayish-puberulent, the pedicels $2-4 \mathrm{~mm}$. long (rarely to $10 \mathrm{~mm}$.); calyx narrowly campanulate, 5-6 $\mathrm{mm}$. long, obtuse and abruptly contracted at the base, more or less hirtellous outside, of ten densely so, at least near the base, white tomentose or sericeous within, the lobes usually 3-4, ovate to lance-ovate, shorter than the tube; corolla 8-10 $\mathrm{mm}$. long, the limb 8-12 mm. across, the tube equalling the calyx, the lobes broadly obovate, rounded, more or less sericeous outside, spreading; stamens exserted, filamen ts glabrous, an thers 2-2.5 mm. long; fruits subglobose, ca. $15 \mathrm{~mm}$. long, $12 \mathrm{~mm}$. in diameter, first orange-red, but black when mature.

\section{GORDIA L.}

References: Ivan M. Johnston, Observations on the species of Cordia and Tournefortia known from Brazil, Paraguay, Uruguay, and Argentina, Contr. Gray Herb. 92: 3-65. 1930; Studies in Boraginaceae, X, The Boraginaceae of Northeastern South America, Journ. Arn. Arb. 16: 1-46. 1935; Notes on some Mexican and Central American species of Cordia, l.c. 21: 336-355. 1940; Studies in 
the Boraginaceae, XVII, A. Cordia section Varronia in Mexico and Central America, l.c. 30: 85-104. 1949; Studies in the Boraginaceae, XIX, B. Cordia section Gerascanthus in Mexico and Central America, l.c. 31 : $179-187.1950$.

Trees or shrubs, of ten with very rough pubescence, the hairs simple, stellate, or branched; leaves all or mostly alternate, petiolate, the margins entire or dentate; inflorescences paniculate, cymose, spicate or capitate; flowers small or large, sessile or pedicellate; calyx tubular to campanulate, sulcate, striate, or smooth, 2-5 lobate, accrescent; corolla most of ten white, funnelform, salverform, or campanulate, the lobes or divisions usually 5 , sometimes more numerous, the lobes in bud plicate or plane, imbricate or subcontorted; stamens as many as the corolla lobes, the filaments equally or unequally inserted on the corolla tube, exserted or included; anthers ovate, oblong or linear, sagittate or hastate; ovary 4-celled, the style elongated, twice bifid, the stigmas capitate or clavate; ovules erect, laterally attached at or below the middle or at the base; fruits drupaceous, the stone very hard, the cells 4 and 1-seeded or by abortion fewer; seeds without endosperm.

About 250 species in the tropics of both hemispheres, most numerous in America. In addition to the 22 species occurring in Guatemala, a number of others are found in Central America.

Inflorescences cymose or paniculate.

Inflorescences of dichotomous cymes.

Cymes lax, open; corollas funnelform; leaves broadly ovate, truncate or rounded at base....................... truncatifolia.

Cymes much reduced, often somewhat headlike; corollas tubular-campanulate; leaves elliptic-oblong or ovate-oblong, cuneate at base. . C. foliosa. Inflorescences paniculate.

Calyces at anthesis tubular, tubular-campanulate, or short-cylindrical.

Calyx tubes conspicuously sulcate.

Indument of stellate hairs.

C. alliodora.

Indument of simple hairs.

Corollas 15-25 mm. long, marcescent.......... gerascanthus.

Corollas 5-11 mm. long, not marcescent.

Leaves rounded cordate or ovate............. cordiformis.

Leaves lanceolate, lance-oblong or oblanceolate.

Leaf blades nearly glabrous, margins conspicuously serrate-dentate.............................. skutchii.

Leaf blades hirsute and scabrous above, sometimes pilose beneath; margins entire or only somewhat serrate near apex.

Calyx tubes striate or obsoletely sulcate or smooth.

C. diversifolia.

Corollas bright orange or vermillion.

Calyces at anthesis truncate at apex, later becoming urn-shaped, enclosing the fruit, the orifice inconspicuous; corolla limb 12-16lobate............................. dodecandra.

Calyces at anthesis 2-3-lobate, later becoming flask-shaped, enclosing the fruit, the orifice narrow but evident; corolla limb 5-6-lobate.

Corollas white. C. sebestena. 
Calyces $10-14 \mathrm{~mm}$. long, the lobes 2 , unequally rupturing, spreading. C. megalantha.

Calyces $3.5-5 \mathrm{~mm}$. long, the lobes 5 , triangular, erect. . . . . C. bicolor. Calyces at anthesis campanulate to broadly campanulate.

Calyx lobes 5, sharply triangular, in fruit spreading and distinctly star-

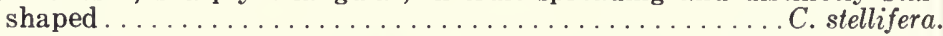

Calyx lobes usually 3 (rarely 4 or 5 ), irregularly torn or broadly and unevenly triangular or rounded, never star-shaped in fruit.

Corollas 5-6 mm. longer than calyces, the lobes broader than long, not reflexed; leaf blades more or less toothed............ dentata.

Corollas only $2-3 \mathrm{~mm}$. longer than calyces, the lobes longer than broad, reflexed; leaf blades entire or nearly so.

Calyces densely fulvous-strigose; inflorescences developing with or before the new leaves...................... collococca.

Calyces only partly and minutely strigose; inflorescences developing after the leaves....................... prunifolia.

Inflorescences spicate or capitate.

Inflorescences spicate.

Spikes long and slender, often interrupted, $3-15 \mathrm{~cm}$. long.

Inflorescences chiefly lateral; leaves ovate, lance-ovate or oblong-ovate 2-6 $\mathrm{cm}$. broad, bases rounded and abruptly decurrent...C. spinescens.

Inflorescences terminal, never arising from leaf axils; leaves lanceolate, lance-oblong or narrowly oblanceolate, $1-3 \mathrm{~cm}$. broad, bases acute or attenuate.......................... curassavica.

Spikes very dense, thick, ellipsoidal, $2-2.8 \mathrm{~cm}$. long . . . . . . . C. coyucana. Inflorescences capitate-globose.

Calyx lobes caudate, the tips $2-7 \mathrm{~mm}$. long.

Indument of stellate hairs . . . . . . . . . pringlei. Indument of simple hairs.

Peduncles $0.5-2 \mathrm{~cm}$. long, hairs usually appressed; heads $1.5-2 \mathrm{~cm}$. in diameter; leaves more or less lanceolate. . . . . . . . . . C. globosa.

Peduncles 3-7 cm. long, hairs usually erect or spreading, not appressed; heads $1-1.5 \mathrm{~cm}$. in diameter; leaves usually ovate or oblong-ovate.

Calyx lobes short-subulate, the tips less than $1 \mathrm{~mm}$. long.

C. bullata.

Leaf bases acute to long-attenuate; petioles $4-15 \mathrm{~mm}$. long; peduncles mostly internodal; indument usually of appressed hairs...... C. inermis.

Leaf bases rounded or cuneate; petioles 1-3 mm. long; peduncles mostly arising from leaf axils; indument usually of spreading hairs . . . C. lineata.

Cordia alliodora (R. \& P.) Oken, All. Naturgeschichte, Bot. 2(2): 1098. 1841; DC. Prodr. 9: 472.1845 (incorrectly as C. alliodora (R. \& P.) Cham.); Johnston, Journ. Arn. Arb. 31: 181. 1950. C. gerascanthus Jacq. Stirp. Amer. 43. 1763, not L. 1759. Cerdana alliodora R. \& P. Fl. Peruv. 2:47, t. 184. 1799. Laurel and bojón (Petén); laurel blanco (Sacatepéquez).

Usually in dry forests or thickets but sometimes in wet, mixed forest or along roadsides, sea level to $1,300 \mathrm{~m}$.; Alta Verapaz; Chiquimula; El Progreso; Escuintla; Guatemala; Huehuetenango; Iza- 


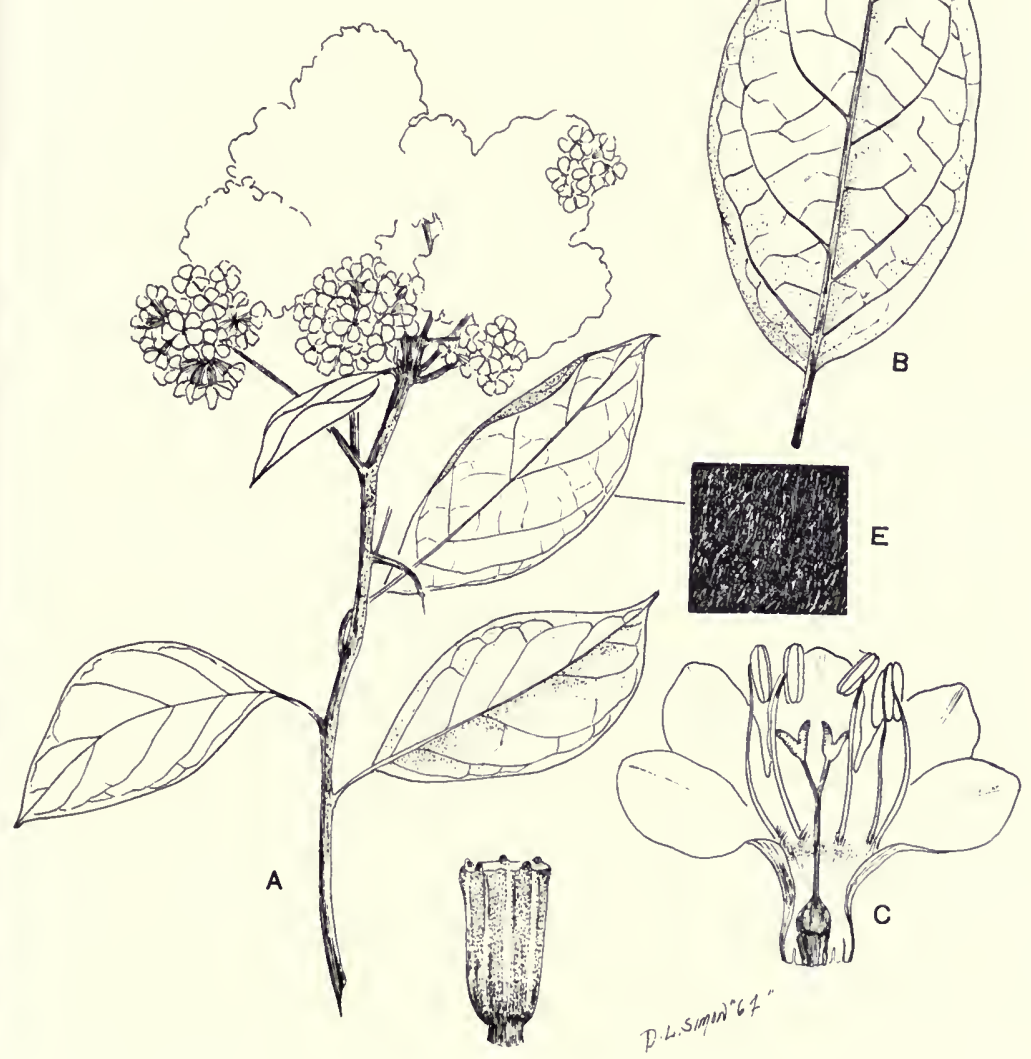

FIG. 23. Cordia alliodora. A, habit of plant, 1/2 natural size; B, large leaf from another collection, $1 / 2$ natural size; C, corolla dissected to show stamens and pistil, $\times 3 ; \mathrm{D}$, calyx, $\times 3 ; \mathrm{E}$, pubescence from under side of leaf, much enlarged.

bal; Jutiapa; Petén; Quezaltenango; Retalhuleu; Sacatepéquez; San Marcos; Santa Rosa; Zacapa. Mexico; Honduras to Panama; West Indies; through South America southward to northern Argentina and western Brazil.

Trees to $25 \mathrm{~m}$. high with trunks to $50 \mathrm{~cm}$. in diameter, sometimes with small buttresses, the bark grayish to dark brown, the branchlets densely or finely stellate- 
pubescent; leaves on petioles $1-3 \mathrm{~cm}$. long, the blades usually $7-15 \mathrm{~cm}$. long but may attain $25 \mathrm{~cm}$., oblong to elliptic, oblong lanceolate, or elliptic-obovate, acute or acuminate, usually attenuate to base, sometimes obtuse, entire, green and glabrate on upper surface, pale beneath and usually densely and minutely stellatetomentulose; inflorescences paniculate, the panicles sometimes as much as $30 \mathrm{~cm}$. broad, usually dense with numerous flowers, the flowers sessile, glomerate; calyx tubular, 4-7 mm. long, stellate-tomentulose, conspicuously 10-costate, every other rib prolonged into a short tooth; corolla marcescent, white, at least twice as long as the calyx, glabrous outside, the lobes oblong-spatulate, broadly rounded or truncate at the apex; stamens equalling or slightly exceeding the corolla, the filaments inserted in throat of tube, dilated and pubescent at base, just above point of insertion; ovary elongated, narrowly ovoid; style included or only shortly exserted, about as long as the ovary; mature fruits ellipsoidal, acute (crowned by the persistent style base), thin-walled and dry, containing one seed.

This is one of the most common trees of the Central American Pacific lowlands and is often used for lumber in Central America.

The branchlets at the base of the inflorescence are often thickened and inhabited by small ants.

Cordia bicolor A. DC. in DC. Prodr. 9: 485. 1845; Johnston, Journ. Arn. Arb. 16: 23. 1935. C. trichostyle Pittier, Contr. U. S. Nat. Herb. 18: 252, f. 102. 1917. C. belizensis Lundell, Am. Midl. Nat. 29: 488. 1943. Sombra de ternero (Izabal).

Wet, mixed forest, thickets, or pastures, sea level to 550 meters; Alta Verapaz, Izabal. Mexico to Panama, northern South America.

Trees, 6-12 m. tall, the slender branchlets hispidulous or hirtellous; leaves on petioles to $1 \mathrm{~cm}$. long, the blades lance-oblong to ovate-oblong, 8-18 cm. long, $3-7.5 \mathrm{~cm}$. wide, gradually or abruptly acuminate, usually rounded to subacute at base, rarely subcordate, the margins essentially entire, of ten undulate or crenate, rarely dentate toward apex, scabrous on upper surface, densely and finely velutinous pubescent beneath or grayish with minute, appressed hairs; inflorescences terminal, cymose-paniculate, usually large, lax, many-flowered; calyx short-cylindrical to tubular-campanulate, obovoid in bud, $3.5-5 \mathrm{~mm}$. long, densely strigose or strigillose, the 5 lobes triangular, subequal; corolla white, the tube equalling the calyx, the lobes $2-3 \mathrm{~mm}$. long, reflexed; stamens exserted, the filaments pilose near the base; fruit inequilaterally ovoid, ca. $1 \mathrm{~cm}$. long, minutely strigillose, seated in the shallow, cupular, somewhat accrescent calyx.

The only character separating $C$. belizensis Lundell from C. bicolor is that of indument of the lower leaf surface, and it appears unstable. The hairs of Lundell's plant (Gentle 4045 from Honduras) are erect or suberect, rather than appressed. However, Turckheim 7963 has appressed hairs on the lower leaf surface while the hairs of the midrib and petiole are erect and the other costae exhibit both types of hairs. Lundell also noted that leaves on his plant were entire while 
those of Gentle 3099 which he cited as $C$. belizensis were dentate. A few leaves of Standley 24990 are also somewhat dentate toward the apex, and the leaf margins of most collections seen are undulate and/or crenate.

Cordia bullata (L.) Roem. \& Schult. Syst. Veg. 4: 462. 1819; Varronia bullata L. Syst. ed. 10: 916. 1759. C. bullata var. angustata DC. Prodr. 9: 496. 1845. C. asperrima DC. l.c. 498. Varronia asperrima (DC.) Friesen, Bull. Soc. Bot. Genève, sér. 2, 24: 155. t. 1, f. 5. 1933. Cambray (Chiquimula and Jalapa).

Damp or dry, brushy, sometimes rocky thickets and slopes, occasionally in fields, 500-1,400 meters; Chiquimula, Escuintla; Guatemala; Jalapa; Petén. Mexico to Nicaragua; West Indies.

Erect shrubs, 1-3 m. tall, the young branches fairly stout, hispid or hispidulous; leaves short-petiolate, the blades broadly ovate to oblong-ovate, $2-6 \mathrm{~cm}$. long, thick, acute at apex, acute to rounded at base, sometimes abruptly contracted and decurrent, margins serrate to serrulate, rugose to bullate and hispid on upper surface, the setae usually arising from bulbous bases, strigose or hispid beneath with erect or ascending hairs, veins conspicuous; inflorescences capitate, the heads globose, $1-1.5 \mathrm{~cm}$. in diameter, many-flowered, the solitary peduncles $3-7 \mathrm{~cm}$. long; calyx campanulate, hispid on upper portion, the lobes triangular and caudate, the filiform tips 1-2 mm. long and hirsute; corolla white, 4-7 $\mathrm{mm}$. long, stamens inserted just above the ring of hairs within the corolla throat; ovary globose to ovoid, the style included; fruits red, 3-4 mm. long, nearly two-thirds enclosed in the accrescent calyx.

Obviously very closely related to C. globosa (Jacq.) HBK. and perhaps not deserving specific status. Although Guatemalan plants are readily separable by length of peduncle and type of indument, some Mexican collections exhibit intergradation between these two torms.

Cordia collococca L. Sp. Pl. ed. 2:274. 1762. C. micrantha Sw. Prodr. 47. 1788 and Fl. Ind. Occ. 1: 460. 1797.

Near sea level to 1,400 meters, fide Standley; Escuintla? Guatemala? Petén. Southern Mexico; El Salvador to Costa Rica; West Indies; Venezuela.

Dioecious trees, 5-15 m. tall, with spreading branches, the young branchlets and stems of inflorescences hirtellous or hispidulous; leaves on petioles $3-13 \mathrm{~mm}$. long, the blades chartaceous, elliptic to obovate or oblong-obovate, deciduous during the dry season, mostly $7-15 \mathrm{~cm}$. long, obtuse or short-acuminate to acuminate at the apex, usually cuneate, sometimes obtuse at base, entire or nearly so, glabrous above or nearly so, sparsely hirtellous or hispidulous beneath, at least along the costa, the hairs mostly erect; inflorescences cymose-paniculate, appearing 
with or even before the new leaves, $4-8 \mathrm{~cm}$. broad, dense or open, many-flowered, the flowers sessile, glomerate; calyx densely fulvous-strigose or strigillose, globose in bud, broadly campanulate at anthesis, ca. $2 \mathrm{~mm}$. long, unevenly 3-5 dentate, separating into $3-5$ uneven lobes in fruit; corolla white, ca. $5 \mathrm{~mm}$. long; filaments of stamens villous below; fruits cherry-red, ca. $8 \mathrm{~mm}$. in diameter.

This species has often been called C. glabra L., but that name is a synonym of Bourreria succulenta Jacq. (see I. M. Johnston, Journ. Arn. Arb. 21: 345. 1940).

Cordia collococca is easily confused with $C$. eriostigma Pittier of El Salvador and Costa Rica, which also has a three-parted, strigose calyx, but produces perfect flowers. According to Johnston, it can be separated by examining the hairs of the lower leaf surfaces, as those of $C$. eriostigma are closely appressed rather than erect. However, two of the Guatemalan specimens in question (Molina 12484, Dept. Escuintla, and Aguilar 371, Dept. Guatemala) have old and glabrate leaves, are fruiting and bear no flowers; the third specimen, Lundell 2743, Petén, has only very young leaves. I have placed them in $C$. collococca, as it is known to have the wider range and is to be expected in Guatemala.

Cordia cordiformis I. M. Johnston, Journ. Arn. Arb. 18: 10. 1937.

At 800 meters; Guatemala; Santa Rosa. Mexico, 3,200 meters.

Dioecious trees of $6 \mathrm{~m}$, or more with rufous or fulvous pubescence, the young branches hirsute with stiff, spreading hairs; leaves on stout petioles, the blades rounded-cordate or ovate, mostly $4-15 \mathrm{~cm}$. long and wide, obtuse or abruptly short-acute at the apex, cordate or rounded at the base and abruptly contracted in to a petiole 1-5 cm. long, repand-denticulate, strigose on the upper surface, paler beneath, densely tomentose with long, soft, of ten tangled hairs, the lateral nerves 4-6 pairs; inflorescences cymose-paniculate, terminal, short-pedunculate, $7-15 \mathrm{~cm}$. broad; calyx 3-4 mm. long, 10-costate, obovoid in bud, short-cylindrical to tubular at anthesis (shallowly cupular in fruit), pubescent with unequal subappressed hairs; corolla of staminate flowers pinkish, $6-7 \mathrm{~mm}$. long, the tube ca. $3 \mathrm{~mm}$., the lobes oblong, recurved; corolla of pistillate flowers not seen; ovary glabrous, globose; dry fruits $7 \mathrm{~mm}$. long.

Cordia coyucana I. M. Johnston, Journ. Arn. Arb. 29: 227. 1948 and 30: 94.1949.

The only Guatemalan collection seen is Standley 76595, rocky oak forest, 1,360 meters, Jalapa. Mexico, Honduras and Costa Rica.

Erect shrubs to $3 \mathrm{~m}$. tall, the young branches short-hirsute to hispidulous; leaves nearly sessile or on petioles to $9 \mathrm{~mm}$. long, the blades lanceolate to lanceovate, 4-8 cm. long, 1-3 cm. wide, acute, acute or obtuse at base, of ten somewhat 
oblique, upper surface usually green and subvelutinous, sometimes scabrid, or papillose without hairs except when young, thinly grey-tomentose beneath with soft, slender hairs 1-2 mm. long, the longer hairs on costae and near the base, margins dentate, at least on upper portions; inflorescences terminal, the very dense spikes ellipsoidal-capitate, $2-2.8 \mathrm{~cm}$. long, $1-1.4 \mathrm{~cm}$. thick, on peduncles $3-5 \mathrm{~cm}$. long; calyx at anthesis $3-5 \mathrm{~mm}$. long, somewhat striate, usually more or less hispidulous, sometimes hirsute with appressed hairs, the lobes broadly triangular; corolla white or greenish-white, 4-6 $\mathrm{mm}$. long, the lobes irregularly sinuate to erose or emarginate; stamens about equalling or somewhat exceeding the sinuses, the glabrous filaments $2-3 \mathrm{~mm}$. long, inserted just above the ring of hairs within the corolla throat; fruits partially enclosed in the accrescent calyx.

These plants, as Johnston pointed out, despite their nearly capitate inflorescences, appear to be very closely related to C. curassavica (Jacq.) Roem. \& Schult., and perhaps may not really be distinct.

The Guatemalan collection and others from Honduras and Costa Rica were originally distributed with an unpublished name provided by Johnston.

Cordia curassavica (Jacq.) Roem. \& Schult. Syst. Veg. 4: 460. 1819; Johnston, Journ. Arn. Arb. 30: 99. 1949. Varronia curassavica Jacq. Enum. Pl. Carib. 14. 1760. V. macrostachya Jacq. l.c. C. macrostachia (Jacq.) Roem. \& Shult. Syst. Veg. 4: 461. 1819. C. brevispicata Mart. \& Gal. Bull. Acad. Brux. 11 (2): 331. 1844. C. hispida Benth. Bot. Sulphur 139. 1845. C. peruviana var. mexicana DC. Prodr. 9: 491. 1845. C. cylindrostachya var. graveolens (HBK.) Griseb. Fl. Brit. W. I. 480. 1861. C. cylindrostachya var. interrupta (DC.) Griseb. l.c. C. brevispicata var. hypomalaca Greenm. Field Mus. Bot. 2: 338. 1912. C. imparilis Macbride, Contr. Gray Herb. 49: 16. 1917. C. chepensis Pitter, Contr. U. S. Nat. Herb. 18: 253. 1917. C. littoralis Pittier, l.c. C. mollis Pittier, l.c. 294. Lantana bullata L. Sp. Pl. 627. 1753, not Cordia bullata (L.) Roem. \& Schult. Chincura, moco de chumpe, morellita (Zacapa).

Damp or dry thickets, hillsides, sometimes in oak forests, sea level to 1,360 meters; Chiquimula; Guatemala; Jalapa; Jutiapa; Retalhuleu; Zacapa. Southern Mexico to Panama; West Indies; northern South America.

Erect shrubs to $3 \mathrm{~m}$. high, the young branches resinous glandular or sparsely or densely hispidulous, short-hirsute, or strigose; leaves nearly sessile or on short petioles to $8 \mathrm{~mm}$. long, the blades thick or thin, lanceolate to oblong-ovate, or narrowly elliptic or oblanceolate, $3-12 \mathrm{~cm}$. long, usually $1-3 \mathrm{~cm}$. broad, but to $7 \mathrm{~cm}$. in one form, acute to acuminate or obtuse, acute or attenuate to the base, usually serrate-dentate, sometimes entire or nearly so, pilose or hirsute above, of ten scabrid, sometimes papillose and without hairs except when young, somewhat paler 
beneath and puberulent, sometimes glandular, the veins conspicuous; inflorescences spicate, terminal (in that they never arise from leaf axils), the spikes $3-10 \mathrm{~cm}$. long, dense or interrupted; calyx campanulate, $2-3.5 \mathrm{~mm}$. long, granulate and strigillose or only somewhat granulate and hispidulous with spreading hairs; corolla white or greenish-white, $3.5-6 \mathrm{~mm}$. long, the lobes $1-1.5 \mathrm{~mm}$. long, broadly rounded and reflexed, or irregularly sinuate to erose or emarginate; stamens about equalling or somewhat exceeding the sinuses, the short, glabrous filaments inserted just above the ring of hairs within the corolla throat; fruits red, partially enclosed in the accrescent calyx, the mature drupe broadly ovoid, $4-5 \mathrm{~mm}$. long.

A complex species of several diverse forms, some of which, as Johnston observed, may eventually be treated as separate species. The two most diverse forms, both in Guatemala, are those plants with elongated, interrupted inflorescence spikes and hispiduous calyces with spreading hairs, and those with shorter, more dense spikes and granulate, strigillose calyces with short, appressed hairs. Corollas of the elongated, interrupted spikes tend to have more broadly rounded lobes, eventually reflexed, while corolla lobes from the shorter, dense spikes are not as often reflexed and are more apt to be irregularly sinuate or erose.

Because the few Guatemalan collections can be readily separated into these two different forms, one is tempted to maintain them separately. However, when the extremely variable collections from Mexico, Honduras, Costa Rica, and Panama are examined, separation becomes most difficult. The shorter, dense spikes of the second group of plants sometimes elongate and become interrupted with age; collections from Honduras and Panama have calyces that are granulate on the lower part, appressed strigillose above, with a few long, spreading hairs on the lobes. Therefore, until further study of the intergradation of these and related plants from the West Indies and South America can be made, they are treated here collectively as C. curassavica (Jacq.) Roem. \& Schult., sens. lat.

Cordia dentata Poir. Encycl. 7: 48. 1806; Vahl, Ecl. Amer. 3: 5, t. 22. 1807; Johnston, Journ. Arn. Arb. 21: 347. 1940. C. calyptrata Bertero ex Sprengel, Syst. 1:649.1825. C.tenuifolia Bertol. Rendic. Sess. Accad. Bologna 1860-61: 73. 1860 and Mem. Accad. Sci. Bologna 11: 199, t. 11. 1861. C. leptopoda Krause, Bot. Jahrb. 37: 628. 1906. C. ovata Brandegee, Pub. Univ. Calif. Bot. 10: 187. 1922. Varronia calyptrata (Bert.) DC. Prodr. 9: 469. 1845; Delessert, Icon. 5: 41, t. 97. 1846. Upay, supay, tiguilote (Jutiapa, Santa Rosa, Zacapa); Upayol (Chiquimula). 
Dry, sandy or rocky slopes and hills, damp or dry thickets or mixed forest; grassy plains and pastures, sea level to 900 meters; Chiquimula; El Progreso; Escuintla; Guatemala; Izabal; Jalapa; Jutiapa; Santa Rosa; Zacapa. Mexico; Honduras to Panama; West Indies; Colombia and Venezuela.

Shrubs or trees to $15 \mathrm{~m}$. tall, the trunk usually short, of ten crooked, the bark light brown and scaly, the branchlets slender, puberulent or short-pilose; leaves on petioles 1-3 cm. long, the blades $3-10 \mathrm{~cm}$. long, elliptic to ovate or obovate-elliptic, rounded or acute at apex, rounded or cuneate at base, subentire, undulate, or coarsely dentate, somewhat scabrous on the upper surface, sparsely pilose beneath, usually along the costa, or almost glabrous, lateral nerves usually 3 to 6 pairs, oblique; inflorescence cymose-paniculate, of ten lax, to $20 \mathrm{~cm}$. broad, many-flowered, the flowers subsessile; calyx $2.5-4.5 \mathrm{~mm}$. long, striate or ribbed, strigose, obovoid in bud, open-campanulate at anthesis; corolla 5-lobate, 8-9 $\mathrm{mm}$. long, funnelform or broadly campanulate, with lobes broader than long, white, cream, or yellow; stamens included, the short, pubescent filaments attached to tube about $2 \mathrm{~mm}$. above its base; ovary subglobose; style usually somewhat exserted; mature fruits white, the flesh mucilaginous, somewhat translucent, 6-10 $\mathrm{mm}$. long (said to attain $16 \mathrm{~mm}$. in the West Indies).

In various publications on the flora of Mexico, Central America, and the West Indies, this tree has been called Cordia alba (Jacq.) Roem. \& Schult., a name probably to be applied to a plant of another family.

Cordia diversifolia Pavon ex A. DC. in DC. Prodr. 9: 474. 1845. C. johnstoni Cufodontis, Arch. Bot. 10: 41. 1934. C. petenensis Lundell, Wrightia 4: 49. 1968 (type from Petén, Contreras 894). Upay (Izabal); chischis (British Honduras).

Wet thickets or forest, along rivers, in pastures and plains, sea level to 450 meters; Alta Verapaz; Escuintla; Izabal; Petén; Retalhuleu; Santa Rosa. Mexico; British Honduras to Panama.

Dioecious trees, to $10 \mathrm{~m}$. tall, the young branches hirsute or hispid with spreading brown hairs; leaves on petioles $5-15 \mathrm{~mm}$. long, the blades lanceolate, lanceoblong, or oblanceolate to broadly elliptic, $3-20 \mathrm{~cm}$. long, obtuse to acuminate, obtuse or acute at base, membranaceous, entire or somewhat serrate near the apex, hirsute and scabrous on the upper surface, paler and short-hirsute or pilose beneath, of ten densely so; inflorescences cymose-paniculate, the panicles usually small, dense or open, few or many-flowered, the branches hirsute; calyx at anthesis tubular hispidulous, the hairs underlain by papillae, costate, 4-7 mm. long, with minute teeth, but separating into 3 uneven lobes in age; corolla creamy white, the tube 6-7 mm. long, the lobes 1-3 mm. long, reflexed; stamens (staminate flowers) well exserted, the filaments villous at base; style in female flowers exserted; absent in male flowers; drupes ovoid, glabrous, ca. $7 \mathrm{~mm}$. long, white at maturity. 
The concept $C$. petenensis Lundell is a small-leaved form of this species.

Cordia dodecandra A. DC. in DC. Prodr. 9:478. 1845. C. angiocarpa A. Rich. in Sagra, Fl. Cub. Fanerog. 2: 110, t. 60. 1853. Plethostephia angiocarpa (Rich.) Miers, Trans. Linn. Soc. Ser. II, 1: 32, t. 8. 1875. Cocopera (Jutiapa). Copte, siricote (Petén, fide Lundell).

Sea level to 900 meters; planted in various places in Jutiapa; probably native in Alta Verapaz and Petén. Mexico; British Honduras; Honduras; Cuba.

Trees, 8-10 m. tall, usually with a broad crown and short trunk, the young branches stout, hispidulous and brown-tomentose; leaves on short or elongated petioles, the blades oblong or suborbicular, 6-15 cm. long, 4-8 cm. broad, rounded or obtuse at apex and at base, entire or somewhat sinuate, very scabrous on both surfaces, hispidulous beneath; inflorescences cymose-paniculate, the cymes fewflowered, the panicles terminal and fairly compact; calyx 1-1.3 cm. long, tubularcampanulate, truncate at apex, glabrous or somewhat tomentulose with a few scattered, straight, appressed hairs, ferruginous-tomentulose near apex and on lobes; corolla funnelform, bright orange, $3-5 \mathrm{~cm}$. long, striate with fairly heavy tomentum along the lines and on margins of lobes, within as well as outside, the limb $2.5-3.2 \mathrm{~cm}$. across, $12-16$ lobate; stamens as many as the corolla lobes, included, the puberulent flaments inserted unevenly on tube at a point about $1.5 \mathrm{~cm}$. above its base; ovary ovoid, seated on a large disc; style elongated, included; mature fruits greenish-yellow, ovoid-oblong, acute at apex, ca. $2 \mathrm{~cm}$. long, the drupe enclosed in a fleshy, urn-shaped calyx.

The very sweet fruit is said to be highly esteemed for making preserves and other dulces.

Cordia foliosa Mart. \& Gal. Bull. Acad. Brux. 11(2): 330. 1844. C. chiapensis Fernald, Proc. Am. Acad. 40: 52. 1904. Salvia santa (Huehuetenango).

At 1,300-2,000 meters; Guatemala; Huehuetenango. Southern Mexico.

Shrubs to $3 \mathrm{~m}$. tall, the slender branches hispidulous or glabrate; leaves on petioles 1-7 mm. long, the blades membranaceous, elliptic-oblong to lance-oblong, usually $3-6 \mathrm{~cm}$. long, $1-2.5 \mathrm{~cm}$. wide, acute or subobtuse at apex, cuneate at base, the margins serrate, upper surface scabrous, lower surface hispidulous; inflorescences cymose, on peduncles $2-5 \mathrm{~cm}$. long, the cymes dichotomous, usually much reduced, somewhat head-like, ca. $2 \mathrm{~cm}$. broad, the flowers subsessile, secund; calyx campanulate (turbinate and apiculate in bud), 3-5 mm. long, scabrous or strigose, the triangular lobes subulate, the tips usually ca. $1 \mathrm{~mm}$. long; corolla campanulate, white, 4-7 mm. long; stamens equalling or exceeding the corolla; fruits ovoid, partially enclosed in the cupular, somewhat accrescent calyx. 
Cordia gerascanthus L. Syst. ed. 10. 936. 1759; Johnston, Contr. Gray Herb. 73: 77. 1924. C. gerascanthoides HBK. Nova Gen. \& Sp. 3: 69. 1818. C. bracteata DC. Prodr. 9: 472. 1845. C. langlassei Loes. in Fedde, Rep. Spec. Nov. 12: 240. 1913. C. rothschuhlii Loes. Bot. Jahrb. 60: 368. 1926. Cerdana gerascanthus (L.) Moldenke, Phytologia 1: 16. 1933. Gerascanthus lanceolatus J. S. Presl, Wseob. Rostl. 2: 1103. 1846, in part. Palo de asta (Zacapa). Laurel negro (Honduras).

Lowlands; the only Guatemalan collections are from Gualan, along railroad, transition from desert to wet land, Zacapa, and from Cadenas, on rocky hill, Petén. Mexico; Honduras; Nicaragua; Costa Rica; West Indies; Colombia.

Trees, usually $10-15 \mathrm{~m}$. tall, but may attain $30 \mathrm{~m}$., with a trunk to $30 \mathrm{~cm}$. in diameter, the branches glabrate; leaves slender-petiolate, lanceolate, lanceolateovate, or elliptic-oblong, entire, smooth or nearly so, 5-12 cm. long, acute or acuminate, acute at the base; flowers sessile in dense cymes, the branches covered with a dense, fine pubescence; calyx 7-10 mm. long, tubular, 10-costate, usually thinly hirsute with short hairs or glabrescent, the 5 lobes deltoid; corolla marcescent, funnelform, white, becoming lavender with age and finally brown, $1.5-2.5 \mathrm{~cm}$. long, the cylindrical tube equalling the calyx, the 5 lobes obovate, truncate to retuse, separating about midway of the limb, the sinuses to $1 \mathrm{~mm}$. wide; stamens usually exserted, filaments inserted in tube just below the throat, more or less pubescent, wooly at base, anthers linear, sagittate; ovary short-cylindrical, style shortly exserted, the branches deeply bifid; fruit ellipsoidal, the fibrous walls enclosing a single seed; mature fruits remaining enclosed by the persistent corolla tube and the calyx, which it somewhat exceeds.

Although heterostyly is common in the species, the flowers of the Guatemalan specimen display long stamens, surpassing considerably the only shortly exserted style.

In Mexico and in the West Indies the wood of the tree is used in carpentry and construction work.

Cordia globosa (Jacq.) HBK. Nova Gen. \& Sp. 3: 76. 1818. Varronia globosa Jacq. Enum. Pl. Carib. 14. 1760. V. humilis Jacq. l.c. Cordia humilis (Jacq.) D. Don, Gen. Syst. 4: 383. 1838. C. jacmeliana Krause, Beih. Bot. Centralb. 32(2): 344. 1914. C. globosa var. humilis (Jacq.) I. M. Johnston, Journ. Arn. Arb. 30: 98. 1949. Varronia jacmeliana (Krause) Friesen, Bull. Soc. Bot. Genève, sér. 2, 24: 177. 1933. V. humilis var. mexicana Friesen, l.c. 162, t. 1, f. 4. V. mexicana Friesen, l.c. Diente de perro, diente de chucho (Zacapa); palo negro (Huehuetenango). 
Damp or dry, brushy, sometimes rocky plains and hillsides, coastal thickets, sand dunes, sea level to 1,600 meters; Chiquimula; Huehuetenango; Retalhuleu; San Marcos; Zacapa. Mexico to Panama; West Indies; northern South America.

Erect shrubs, 1-3 m. tall, the young branches strigose with appressed hairs, leaves short-petiolate, the blades lanceolate, lance-ovate or ovate-oblong, $1.5-7 \mathrm{~cm}$. long, acute or subacute at apex, acute to rounded at base, sometimes abruptly contracted and decurrent, the margins crenate-dentate to dentate, somewhat rugose and strigose with appressed hairs on upper surface, more densely appressed strigose on lower surface, the veins usually elevated and prominent; inflorescences capitate, the heads globose, $1.5-2 \mathrm{~cm}$. in diameter, many-flowered, on peduncles $0.5-2 \mathrm{~cm}$. long; calyx campanulate, hispid, the lobes triangular and caudate, the filiform tips 1-2 mm. long and hirsute; corolla white, 5-9 mm. long; stamens inserted just above the ring of hairs within the corolla throat; ovary globose to ovoid, the style included; fruits red, ovoid, partially enclosed in the accrescent calyx.

Cordia inermis (Mill.) I. M. Johnston, Journ. Arn. Arb. 30: 95. 1949. Lantana inerma Miller, Gard. Dict. 1768. Cordia cana Mart. \& Gal. Bull. Acad. Brux. 11(2): 331. 1844. C. insularis Greenm., Proc. Am. Acad. 33: 482. 1898. Cuajatinta (Guatemala).

Damp or dry lowland forest or on brushy, rocky slopes, near sea level to 1,200 meters; Alta Verapaz; Chiquimula; Escuintla; Guatemala; Santa Rosa; Zacapa. Mexico to Panama. Northern Colombia.

Shrubs to $3 \mathrm{~m}$. tall, usually densely branched, the slender branches strigose with short, whitish appressed hairs; leaves on petioles $4-15 \mathrm{~mm}$. long, the blades membranaceous, lanceolate to oblong, ovate or elliptic, $2.5-7.5 \mathrm{~cm}$. long, usually $1-2.5 \mathrm{~cm}$. broad (rarely to $5 \mathrm{~cm}$. broad), long-acuminate to subobtuse at apex, acute to long-attenuate at base, the margins serrate or subentire, the upper surface green and somewhat scabrous, paler and often densely strigose beneath; inflorescences capitate, the heads globose, $5-10 \mathrm{~mm}$. in diameter, usually with 20 or more flowers, the peduncles $1-4 \mathrm{~cm}$. long, terminal or axillary (mostly internodal), their indument usually of appressed hairs; calyx campanulate, $1.5-3 \mathrm{~mm}$. long, strigose, the triangular lobes short-subulate, $0.5-1 \mathrm{~mm}$. long; corolla white or greenish white, 3-5 mm. long, tubular; stamens about equalling or slightly exceeding the corolla; ovary globose to ovoid, the style equalling the corolla or somewhat exserted; fruits red, 4-5 mm. long, about three-fourths enclosed by the accrescent calyx.

Cordia lineata (L.) Roem. \& Schult. Syst. Veg. 4: 464. 1819; Johnston, Journ. Arn. Arb. 30: 91. 1949. Varronia lineata L. Syst. ed. 10: 916. 1759. Cordia ulmifolia var. lineata (L.) DC. Prodr. 9: 495. 1845. Lantana corymbosa L. Sp. Pl. 628. 1753.

Damp thickets, brushy slopes, sea level to 225 meters; Izabal. Southern Mexico to Panama; West Indies; possibly northern South America. 
Slender, erect shrubs of 1-5 meters; the stems hirtellous or pilose with short and long, spreading hairs; leaves on petioles 1-3 mm. long, the blades membranaceous, lanceolate to ovate-lanceolate, $3.5-10 \mathrm{~cm}$. long, 1-3 cm. broad, acute to long-acuminate at apex, rounded or cuneate at base, green above, scabrous or somewhat tuberculate and strigose, densely and finely pubescent beneath, usually somewhat velutinous, margins serrate or subentire; inflorescences capitate, globose, the heads usually $5-10 \mathrm{~mm}$. in diameter, usually 6-12-flowered, the peduncles $2-3 \mathrm{~cm}$. long, the majority arising from leaf-axils, their indument usually of spreading hairs; calyx campanulate, $2-3 \mathrm{~mm}$. long, strigose, the triangular lobes shortsubulate, ca. $0.5 \mathrm{~mm}$. long; corolla white or greenish white, $3-5 \mathrm{~mm}$. long, tubular; stamens about equalling or slightly exceeding the corolla; ovary globose to ovoid, the style equalling the corolla or somewhat exserted; fruits red, 4-5 mm. long, nearly three-fourths enclosed by the accrescent calyx.

Reported from Mexico and Central America as C. corymbosa (L.) Don and as $C$. ulmifolia Juss., both untenable names (Johnston, Journ. Arn. Arb. 16: 33. 1935). Also reported as C. polycephala (Lam.) I. M. Johnston, which according to Johnston is a separate species of the West Indies and northern South America. However, further studies may well prove it to be synonymous with $C$. lineata.

Cordia megalan tha Blake, Proc. Biol. Soc. Wash. 36:200. 1923. C. macrantha Blake, Contr. U. S. Nat. Herb. 24: 19. 1922, not Chodat. Laurel blanco (Zacapa).

Open or forested slopes, at or a little above sea level; Izabal; Zacapa. Honduras.

Trees, 10-25 meters tall, the trunk to $66 \mathrm{~cm}$. in diameter, the branchlets glabrous or nearly so; leaves on slender petioles $1-4 \mathrm{~cm}$. long, the blades chartaceous, elliptic-oblong to broadly obovate, or ovate, mostly $7-15 \mathrm{~cm}$. long, $3-8 \mathrm{~cm}$. wide, obtuse or acute or broadly rounded and abruptly pointed at apex, cuneate to almost rounded at base, entire or practically so, glabrous; inflorescences cymosepaniculate, terminal, 6-12 $\mathrm{cm}$. long, the branches pubescent and glandular, the pedicels $2-3 \mathrm{~mm}$. long; calyx broadly tubular, striate, glabrous or minutely puberulent, 10-14 mm. long, with 2 unequal, broadly triangular, ciliolate, spreading lobes; corolla white, marcescent, $2-3 \mathrm{~cm}$. long, the limb to $4 \mathrm{~cm}$. broad, the 5 lobes triangular-ovate, obtuse or acute; stamens about equalling the sinuses, the filaments inserted in tube below the throat, somewhat hirsute, densely pubescent at and above point of attachment; ovary glabrous, short-cylindrical to oblong; style included; fruits enclosed in the persistent corolla.

Cordia pringlei Robins. Proc. Am. Acad. 26: 169. 1891. Varronia pringlei (Robins.) Friesen, Bull. Soc. Bot. Genève, ser. 2, 24: 168. 1933. C. pringlei var. altatensis Brandegee, Zoe 5: 219. 1904. C. asterothrix Killip, Journ. Wash. Acad. 17: 330. 1927. C. storkii Standley, Field Mus. Bot. 18: 984. 1938. Cambray, chiligua, colmillo de perro, diente de perro (Jutiapa). 
Dry, brushy, often rocky plains and hillsides, 200-900 meters; Chiquimula; El Progreso; Jutiapa; Zacapa. Mexico to Costa Rica.

Erect shrubs to $3 \mathrm{~m}$. tall, the older branches dark and glabrate, the younger ones densely stellate-tomentose; leaves on stout petioles $0.5-2 \mathrm{~cm}$. long, the blades thick, oblong-ovate to broadly ovate, $3-10 \mathrm{~cm}$. long, 2-7 cm. broad, acute or subacute at apex, rounded or truncate at base, of ten abruptly decurrent, sometimes cordate, coarsely and unevenly crenate-dentate, densely and minutely stellatepubescent on the upper surface, densely and softly stellate-tomentose beneath, pale; inflorescences capitate, on terminal peduncles $2-10 \mathrm{~cm}$. long, the heads globose, dense, many-flowered, $2-2.5 \mathrm{~cm}$. in diameter; calyx stellate-pubescent, the tube narrowly campanulate (turbinate in bud), 6-7 mm. long, the triangular lobes caudate, the filiform tips 6-7 mm. long; corolla white, funnelform, more than twice as long as the calyx, the limb $1-1.5 \mathrm{~cm}$. broad; stamens exceeding the tube; ovary ovoid, the style included; fruits ovoid or obovoid, partly enclosed in the somewhat accrescent calyx.

Cordia stellata Greenm. of Mexico closely resembles C. pringlei, differing only in the calyx lobes which lack the filiform tips and its usually slightly smaller flowering heads. C. stellata may not deserve specific rank.

Cordia prunifolia I. M. Johnston, Journ. Arn. Arb. 21: 353. 1940 .

In Guatemala known only from the type, Skutch 298, coffee plantation, evidently a relict of the forest, Sacatepéquez, 1,080 meters. Mexico, Costa Rica, Panama.

A tree of $21 \mathrm{~m}$., the trunk $40 \mathrm{~cm}$. in diameter, the bark brown, finely checkered, young branchlets almost glabrous; leaves on petioles to $1 \mathrm{~cm}$. long, the blades stiffmembranaceous, oblong-ovate to elliptic-oblong, mostly 10-12 cm. long and 3.5$5.5 \mathrm{~cm}$. wide, abruptly acute or short-acuminate, obtuse or acute at the base, entire or nearly so, lustrous above and glabrous or nearly so, slightly paler beneath, with sparse appressed hairs or practically glabrous; inflorescences terminal and lateral, cymose-paniculate, short-pedunculate, 5-12 cm. broad, lax, many-flowered, the slender branches brownish-puberulent; calyx obovoid-globose in bud and strigillose, campanulate at anthesis and becoming almost glabrous, $3-3.5 \mathrm{~mm}$. long, irregularly lobate, the lobes usually 3 , usually rounded but occasionally broadly triangular; corolla white, 5-5.5 mm. long, the lobes oblong, somewhat recurved; stamens exserted, the filaments villous below; ovary glabrous; fruits unknown.

This species is much like $C$. nitida Vahl of the West Indies, and it is quite possible that this plant, as well as C. lasiocalyx Pittier and C. lucidula Johnston of Costa Rica and Panama should properly be referred to C. nitida.

Cordia sebestena L. Sp. Pl. 190. 1753.

Near sea level; British Honduras. Mexico (Yucatan and Quintana Roo); Honduras. West Indies to northern Venezuela. 
Shrubs or small trees, usually not more than $8 \mathrm{~m}$. tall, the branches stout; leaves on stout petioles $1-3 \mathrm{~cm}$. long, the blades ovate to ovate-elliptic, somewhat undulate, acute, rounded or almost truncate at base, entire or somewhat dentate near apex, scabrous above, somewhat scabrous and pubescent beneath, mostly 6-18 cm. long, 5-14 cm. wide, with 5-9 pairs of primary lateral veins; inflorescences pedunculate, the panicles composed of dichotomous, few-flowered cymes, the flowers on pedicels usually 4-6 $\mathrm{mm}$. long but may be $2-15 \mathrm{~mm}$. long; calyx tubularcampanulate, rupturing irregularly but usually 2-3-lobed at anthesis, usually pubescent with appressed hairs inside and out, ca. $1.5 \mathrm{~cm}$. long; corolla funnelf orm, bright orange to vermilion, $3-4 \mathrm{~cm}$. long, the limb $3-3.5 \mathrm{~cm}$. across, 5-6 lobate; stamens included or slightly exserted, attached to tube at a point $2-3 \mathrm{~mm}$. below throat, the anthers $3-3.5 \mathrm{~mm}$. long; style included, elongated to ca. $20 \mathrm{~mm}$., persistent; mature fruits hard, dry, ovoid, $2-2.5 \mathrm{~cm}$. long, completely enclosed in the accrescent, flask-shaped calyx which becomes white and fleshy.

Although not reported from Guatemala, these wide ranging plants might be expected along the east coast. They are very ornamental and are widely cultivated in the tropics.

\section{Cordia skutchii I. M. Johnston, Journ. Arn. Arb. 21: 339. 1940.} Canela.

Wet, mixed forest, 1,150-1,500 meters; endemic; Quezaltenango (types: pistillate, Skutch 1426; staminate, Skutch 1425).

Dioecious trees to $8 \mathrm{~m}$. tall, the branchlets slender, hispidulous with spreading or ascending hairs; leaves on petioles $1-2 \mathrm{~cm}$. long, the blades membranaceous, oblanceolate, $10-30 \mathrm{~cm}$. long, $2.5-9 \mathrm{~cm}$. wide, long-acuminate, long-attenuate to the base, serrate-dentate, with scattered hairs on the upper surface, glabrate beneath but with scattered hairs on veins; inflorescences terminal, on long, slender peduncles, cymose-paniculate, lax and open, $7-16 \mathrm{~cm}$. broad, many-flowered; calyx tubular at anthesis, $3-5 \mathrm{~mm}$. long, costate or striate, minutely tuberculate or muriculate and hispidulous, irregularly $3-5$ dentate, separating into 3 uneven lobes; corolla white, pubescent with in throat, $9-11 \mathrm{~mm}$. long when staminate, $5 \mathrm{~mm}$. long when pistillate, the lobes ca. $2-4 \mathrm{~mm}$. long, reflexed; stamens of staminate flowers well exserted, pubescent near point of insertion in throat; mature fruits white, ellipsoid-ovoid, to $1 \mathrm{~cm}$. long, much exceeding the shallowly cupular fruiting calyx.

As Johnston has pointed out, C. skutchii closely resembles C. $d i$ versifolia Pavón but is more slender, more loosely branched, less hirsute, with thinner, nearly glabrous leaves which are always obviously dentate. Johnston felt that $C$. skutchii may be more closely related to the broader-leaved $C$. salvadorensis Standley, which is not as hirsute, with hairs of calyx and herbage much more closely appressed. Although the three plants can be readily separated by leaf form and margin, the flowers of the three are so much alike that the validity of supposed specific difference may be questioned. 
Cordia spinescens L. Mant. 2:206. 1771; I. M. Johnston, Journ. Arn. Arb. 30: 103. 1949. Varronia ferruginea Lam. Illust. 1: 418. 1791. Cordia riparia HBK. Nova Gen. \& Sp. 3: 71, t. 207. 1818. C. ferruginea (Lam.) Roem. \& Schult. Syst. Veg. 4: 468. 1819. C. crenulata A. DC. in DC. Prodr. 9: 492. 1845. Bejuco negro (Izabal and Sacatepéquez); kekxej (Alta Verapaz).

Usually in damp thickets, ravines, along rivers or swamps, occasionally in mixed or pine forests, sea level to 1,650 meters; Alta Verapaz, Chiquimula, Escuintla, Guatemala, Huehuetenango, Izabal, Petén, Quezaltenango, Retalhuleu, Sacatepéquez, San Marcos, Santa Rosa, Zacapa. Western and southern Mexico, British Honduras to Panama; Colombia.

Erect or somewhat scandent shrubs, 2-4 m. tall, usually with recurved branches, the stems and branches tomentose, hispidulous, or glabrate; leaves on petioles $0.5-2 \mathrm{~cm}$. long, the blades membranaceous, usually broadly ovate, sometimes oblong-ovate or lance-ovate, rarely lanceolate, $4-15 \mathrm{~cm}$. long, acute or acuminate, rounded and abruptly decurrent at the base, usually serrate to subentire, rarely entire, dark green above, scabrous or glabrate, paler beneath and sparsely or densely ferruginous-pubescent, the hairs usually erect, rarely appressed; inflorescences spicate, the spikes solitary, chiefly axillary, usually as long as or longer than the leaves, dense or in terrupted, many-flowered; calyx campanulate, $2-4 \mathrm{~mm}$. long, 5-6 dentate, usually not costate, or the costae obsolete, usually hispidulous, the hairs of ten underlain by minute papillae; corolla $2-4 \mathrm{~mm}$. long, usually exceeding the calyx by only $1 \mathrm{~mm}$., rarely by $2-3 \mathrm{~mm}$., greenish-white or cream, nearly truncate or the ruffled or laciniate margin giving the appearance of numerous, small, uneven lobes or teeth; stamens exserted, the filaments inserted in throat of corolla, glabrous to point of insertion and there surrounded by shaggy hairs which ring the corolla throat; ovary glabrous; style included; fruits red, the drupes partially or completely enclosed in the accrescent calyx.

Cordia stellifera I. M. Johnston, Journ. Arn. Arb. 21:350. 1940.

Usually in wet forests, fields, thickets, or on slopes near rivers, occasionally in open pine forest, 50-225 meters; Alta Verapaz; Izabal; Petén. Southern Mexico; British Honduras; Honduras; Costa Rica.

Trees, 6-12 m. tall, the young branches slender, minutely pubescent with mostly appressed hairs or almost glabrous; leaves on petioles $0.5-1.5 \mathrm{~cm}$. long, the blades membranaceous, elliptic-oblong to broadly oblanceolate, usually 8-11 (16) $\mathrm{cm}$. long, 4-7.5 cm. wide, obtuse to acuminate, acute at the base, entire or nearly so, lustrous above, almost glabrous and smooth to the touch, glabrous beneath or with scattered, minute, appressed hairs; inflorescences lax, long pedunculate, 5$12 \mathrm{~cm}$. broad, the branches strigillose or glabrate; calyx subglobose in bud, densely strigillose, open-campanulate at anthesis, $3 \mathrm{~mm}$. long, the $4-5$ lobes triangular, acute; fruiting calyx spreading and stelliform, 6-9 mm. broad; corolla white or cream, $7 \mathrm{~mm}$. long, the lobes broadly ovate; stamens villous near base; ovary glabrous, style 3-5 $\mathrm{mm}$. long; fruits depressed transverse-ovoid. 
It may be that this species should be referred to C. laevitata Lam. of the West Indies, which differs from C. nitida Vahl only in its smaller leaves and puberulous calyx. This group of Cordias, including C. eriostigma Pittier (Costa Rica and El Salvador), C. lasiocalyx Pittier, C. lucidula Johnston, and C. prunifolia Johnston, are certainly very closely related and monographic study is needed.

Cordia truncatifolia Bartlett, Proc. Am. Acad. 43: 58. 1907. C. microsebestena Loes. Verh. Bot. Ver Brandenb. 55: 187. 1913. C. gualanensis Donn.-Sm. Bot. Gaz. 55: 438. 1913.

Dry hills and thickets, 100-650 meters; Chiquimula, El Progreso; Zacapa. Mexico (Oaxaca and Guerrero).

Shrubs or small trees, to $8 \mathrm{~m}$. tall, the branches rather stout, puberulent or glabrate; leaves membranaceous, on petioles $3-10 \mathrm{~mm}$. long, the blades broadly ovate, $2-7.5 \mathrm{~cm}$. long and $2-5 \mathrm{~cm}$. broad, abruptly acute at apex, rounded or truncate at the base, entire, subentire, or coarsely crenate-dentate, scabrous on the upper surface, softly pubescent or subtomentose beneath; inflorescences cymose, the cymes dichotomous, usually 6-12-flowered, pedunculate, the pedicels $2-7 \mathrm{~mm}$. long; flowers of two forms: calyces of the small-flowered form ca. $6 \mathrm{~mm}$. long at anthesis, broadly campanulate, brownish-sericeous, the 5 costae obscured by indument, the 5 (sometimes 6 ) lobes subulate, calyces of the large-flowered form $10 \mathrm{~mm}$. long, campanulate, sericeous but with longer hairs along costae and near base of tube, the 5 lobes long-attenuate or laciniate, $4-5 \mathrm{~mm}$. long, both forms apiculate in bud and accrescent; corollas funnelform, white or yellowish white, puberulent, those of the small form 15-16 mm. long, those of the larger form $20-22 \mathrm{~mm}$. long, the lobes of both obovate, ca. one-third as long as the tube; stamens included, the glabrous filaments arising near the base of the tube and adnate to it for almost half their length; ovary ovoid, style elongating but always included, those of the small form ca. 3-6 mm. long, the larger ones 8-11 mm. long; fruits subglobose, the drupes orange-yellow, glabrous, ca. $1 \mathrm{~cm}$. long, finally rupturing the calyx.

It is not yet known whether both forms are fertile, as the calyx becomes greatly enlarged in fruit. The ovaries of both forms bear minute ovules.

Both forms have been confused with C. seleriana Fernald, which they closely resemble; however, the calyx of $C$. seleriana has only three lobes, although two of these lobes may each bear two minute teeth. Further, the calyx in bud is never apiculate, and the style may be $15 \mathrm{~mm}$. long.

\section{GYNOGLOSSUM L.}

Reference: M. Gürke in Engler \& Prantl, Pflanzenf. IV, 3a: 102. 1893. 
Perennial or biennial herbs, usually branched, pubescent; leaves alternate, the basal leaves usually long-petiolate, the cauline ones usually sessile; inflorescences racemose, the cincinni short and densely flowered at first, usually elongating and becoming lax and remotely flowered, mostly ebracteate, sparsely branched or forming broad panicles; the flowers pedicellate or subsessile, the pedicels of ten recurved in fruit; calyx deeply 5-lobed, little accrescent in fruit, spreading or reflexed; corolla blue, violet, or rarely white, the tube short, the throat closed by small appendages, the 5 lobes imbricate, obtuse, spreading; stamens 5, included, inserted on the corolla tube, the filaments short; anthers ovoid or short-oblong, obtuse; ovary 4-lobed, the style short or elongated, the small stigma plane or subcapitate; ovules horizontal; nutlets 4, depressed, widely spreading in fruit, adnate to the gynobase by almost the whole lower surface, dorsally convex, flat, or surrounded by a raised border, glochidiate-muricate.

About 60 species, in temperate and subtropical regions of both hemispheres, mostly in the Old World. Only a few are native in North America; only one is known from Mexico (C. pringlei Greenm.), and none from Guatemala; the following species is treated here as it has been collected as an escape from cultivation.

Cynoglossum amabile Stapf \& Drumm. Kew Bull. 1906: 202. 1906.

Native of China; cultivated frequently for ornament in Guatemala, in parks and gardens; naturalized in Sololá and Sacatepéquez. Also naturalized in Mexico and in scattered localities throughout Central America, Ecuador and Colombia.

Branched, erect, perennial herbs to about $50 \mathrm{~cm}$. tall, rather finely grayishpubescent throughout and somewhat hirsute; basal leaves petiolate, the blades lance-elliptic, acute at each end, $5-10 \mathrm{~cm}$. long, $2-3.5 \mathrm{~cm}$. wide, the cauline leaves sessile, of ten clasping, oblong or lanceolate, obtuse or acute, entire or undulate, the lower ones to $15 \mathrm{~cm}$. long, decreasing in size upward to 2 or $3 \mathrm{~cm}$. long; the cymes of inflorescence forming a large panicle, the pedicels in flower scarcely $2 \mathrm{~mm}$. long, in age $4 \mathrm{~mm}$. long and reflexed; calyx $2-3 \mathrm{~mm}$. long, the segments ovate, subacute; corolla usually blue, sometimes white, the limb 5-10 $\mathrm{mm}$. broad; nutlets ovate, depressed dorsally, $3 \mathrm{~mm}$. long when mature, whitish, densely glochidiate-muricate, the spines very short, usually less than $1 \mathrm{~mm}$. long.

Because of its easily dispersed nutlets which attach themselves readily to passing objects, this plant, already plentiful in some of the cafetales about Antigua, Sacatepéquez, may well become a naturalized weed in the temperate regions of Guatemala.

\section{EHRETIA L.}

References: Linnaeus, Syst. ed. 10:936. 1759; M. Gürke in Engler \& Prantl, Pflanzenf. IV, 3a:87-88. 1897. 
Trees or shrubs, glabrous or pubescent; leaves alternate, petiolate, the blades frequently coriaceous, of ten scabrous, the margins entire, dentate, or serrate; inflorescences panicles or corymbose cymes, terminal; calyx small, 5-parted, the segments imbricate or open in bud; corolla tube short or cylindric, the throat sometimes ampliate, the 5 lobes imbricate, obtuse, spreading or recurved; stamens 5 , usually exserted, the filaments inserted on the corolla tube, the anthers ovoid or oblong; ovary 2-celled with each cell imperfectly 2-locellate, or the ovary 4-celled, style terminal, bifid, the 2 stigmas terminal, clavate or capitate; ovules attached laterally; fruit small, drupaceous, generally globose or subglobose, pale yellow, orange, red, or purple, at maturity breaking into two 2-seeded or four 1-seeded pyrenes; seeds usually straight; endosperm scant, the cotyledons ovate, not plicate.

Perhaps 50 species, in the tropics of both hemispheres, chiefly in the Old World. Only two species are known to occur in Guatemala with three more in Mexico and two others reported from southern Central America.

Leaf blades entire; panicles usually longer than the leaves.......... tinifolia. Leaf blades dentate or serrate; panicles usually shorter than the leaves. E. luxiana.

Ehretia luxiana Donn.-Sm., Bot. Gaz. 18: 5. 1893. Pepenance (El Quiché).

Damp, mixed or pine forest, wet thickets, or brushy hillsides, 1,000-2,500 meters; Alta Verapaz; Guatemala; Quezaltenango; El Quiché; Sacatepéquez; San Marcos. Southern Mexico; El Salvador.

Trees, usually 6-9 (rarely to 15 ) $\mathrm{m}$. high, the young branches ferruginous, glabrous or sometimes with scattered hairs; leaves on petioles 1-2.5 cm. long, the blades chartaceous to subcoriaceous, ovate to lance-oblong or elliptic-oblong, mostly 6-15 cm. long, acute or acuminate, acute or rounded at the base, the margin serrate or dentate, essentially glabrous on both surfaces or sparsely hispidulous beneath with some scattered, stiff hairs, especially along the costa; older leaves sometimes becoming scabrous; panicles terminal, usually shorter than the leaves, the stems nearly glabrous or puberulent with appressed hairs, densely flowered, the flowers sessile or short-pedicellate; calyx $2-2.5 \mathrm{~mm}$. long, glabrous or obscurely puberulent, the lobes obtuse, ciliate; corolla white, 4-5 $\mathrm{mm}$. long, glabrous, the broad lobes spreading or reflexed; stamens long-exserted; dry fruits subglobose, to $1 \mathrm{~cm}$. long, glabrous; fresh fruits juicy, white, oblong-ovoid, ca. $13 \mathrm{~mm}$. long.

Ehretia latifolia A. DC. of central and southern Mexico, may be separated from E. luxiana by its lanceolate, acute sepals, and its usually smaller leaves (mostly $4-8 \mathrm{~cm}$. long) which are always very scabrous on the upper surface, and finely pubescent beneath.

Ehretia tinifolia L. Syst. Nat. ed. 10: 936. 1759.

Twice collected in the Department of Guatemala, Steyermark 48083a, cultivated, and Aguilar 530, possibly also cultivated. Mexico; Honduras; West Indies. 

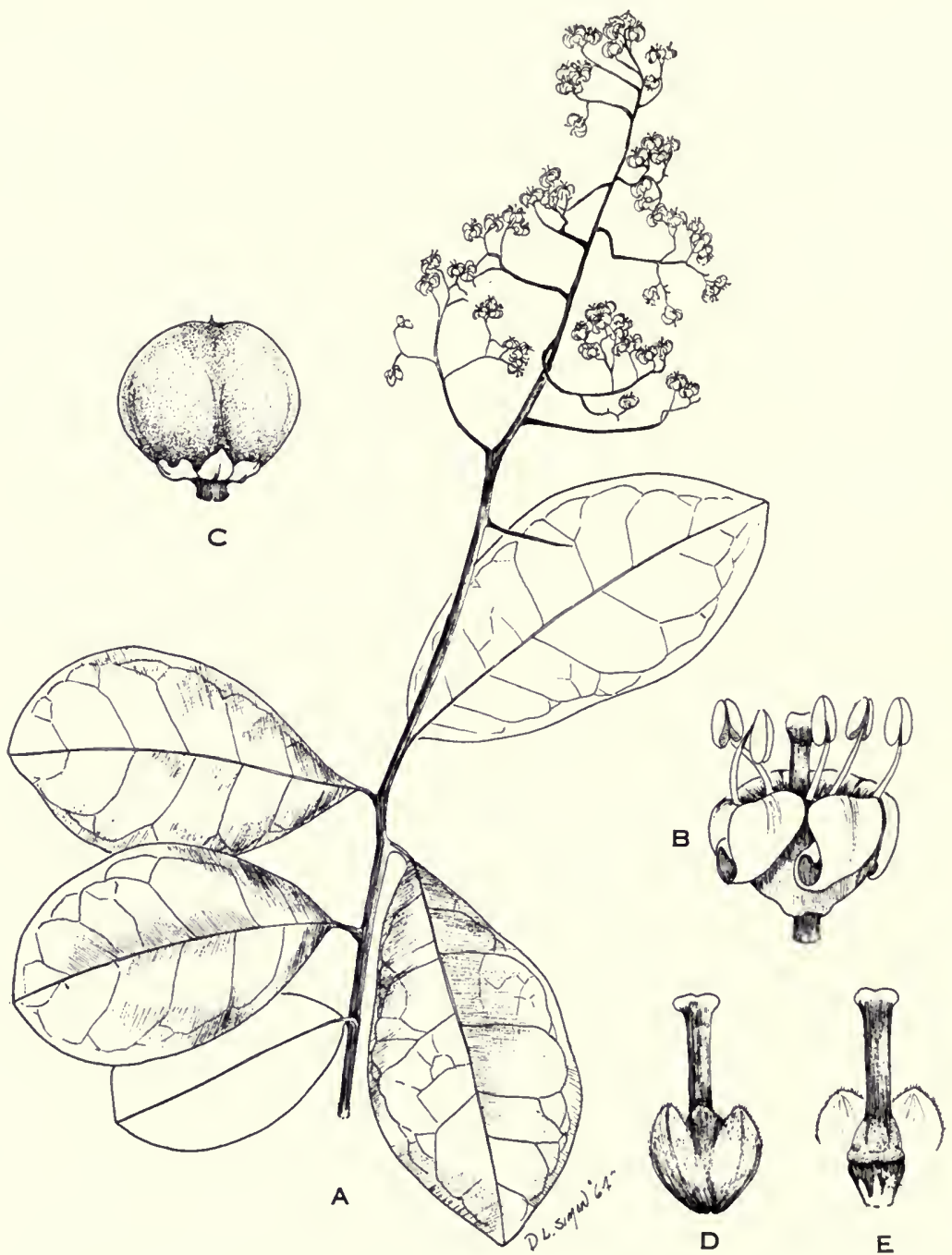

E

FIG. 24. Ehretia tinifolia. A, habit, $1 / 2$ natural size; B, flower, $\times 5$; C, fruit, $\times 4 ; \mathrm{D}$, calyx with style and stigma, $\times 5 ; \mathrm{E}$, dissection showing pistil, $\times 5$.

Trees or shrubs, essentially glabrous throughout, said to attain a height of $25 \mathrm{~m}$. in some regions; leaves short-petiolate, the blades chartaceous, usually lustrous, oblong or elliptic-oblong to ovate, $4-13 \mathrm{~cm}$. long, $2.5-5 \mathrm{~cm}$. wide, usually rounded, sometimes acute at the apex, obtuse or rounded at the base, margins entire; panicles terminal, many-flowered, usually longer than the leaves, dense or open; calyx 1.5-2 mm. long, glabrous, the lobes rounded, ciliate; corolla white, 3-5 mm. long, the lobes oblong, reflexed; stamens and style long-exserted; fruits subglobose to ovoid, 5-6 $\mathrm{mm}$. in diameter, red or purple. 


\section{HACKELIA Opiz}

Reference: A. Brand, Pflanzenreich IV. 252: 117-135. 1931.

Herbs, usually perennial, rarely biennial or annual, pubescent; leaves alternate, entire or nearly so, at least the lower ones conspicuously petiolate; fiowers small, usually blue, the raceme-like inflorescences terminal and axillary, usually forming a panicle, calyx deeply parted; corolla cylindric or funnelform to campanulate or subrotate, the throat usually closed by large appendages; stamens included, the short filaments attached to corolla tube below each sinus; style and stigma simple; gynobase pyramidal, with 4 large triangular pits; nutlets 4 , aculeate, with a large central scar, of ten dissimilar.

About 40 species, mostly in temperate North America, two or three in South America, one in Europe, a few in Asia. Only the following are known in Central America.

Lower leaf surfaces very densely strigose or sericeous with closely appressed hairs; spines of armed nutlets ca. $1.5 \mathrm{~mm}$. long ................. skutchii.

Lower leaf surfaces pubescent with spreading hairs or rather sparse, shorthairs; spines of armed nutlets $3-4 \mathrm{~mm}$. long...................... mexicana.

Hackelia mexicana (Schlecht. \& Cham.) I. M. Johnston, Contr. Gray Herb. 68: 46. 1923. Cynoglossum mexicanum Schlecht. \& Cham. Linnaea 5: 114. 1830. Echinospermum mexicanum Hemsl. Biol. Cent. Am. Bot. 2: 377. 1882. Lappula mexicanum Greene, Pittonia 2: 182. 1891. L. costaricensis Brand in Fedde, Rep. Sp. Nov. 18: 310. 1922. L. guatemalensis Brand, l.c. 311 (type from Huehuetenango, Seler \& Seler 3144). Hackelia costaricensis (Brand) I. M. Johnston, Contr. Gray Herb. 68: 46. 1923. H. guatemalensis Brand, Pflanzenr. IV. 252: 120. 1931. H. stricta I. M. Johnston, Journ. Arn. Arb. 29: 238. 1948. Mozote.

Damp or wet meadows, thickets, or mixed forest, sometimes in pine or Cupressus forest, 1,400-3,500 meters; Chimaltenango; Huehuetenango; Jalapa; Quezaltenango; El Quiché; San Marcos. Mexico; Costa Rica; Panama; Ecuador and Venezuela.

Erect, usually coarse, annual, biennial or perennial herbs to $75 \mathrm{~cm}$. tall, branched, from a thick, sometimes repent rootstock, the stems sparsely or densely pilose with spreading white hairs; basal leaves on very long, slender petioles to $23 \mathrm{~cm}$. long, the blades broadly ovate, ovate, lance-ovate, or elliptic, 5-14 cm. long and $2-5.5 \mathrm{~cm}$. wide, the cauline leaves short-petiolate or the uppermost sessile, sometimes clasping, the blades thin, elliptic to oblong-lanceolate, $2-12 \mathrm{~cm}$. long, acute, when petiolate narrowed below into the broad petiole, rather sparsely hirsute with short, mostly spreading whitish hairs; cincinni many-flowered, lax, bracteate, usually forming a large panicle, the flowers pedicellate, becoming remote in age, the pedicels reflexed in age, longer than the calyx, almost $1 \mathrm{~cm}$. long in fruit; calyx at anthesis 1-2 mm. long, lobate for one-half to two-thirds its length, accres- 
cent, $2-3 \mathrm{~mm}$. long in fruit, pilosulous, the lobes ovate, subacute; corolla blue to lavender, the tube 1-2 mm. long, the broad, rounded lobes $2-3 \mathrm{~mm}$. long, the throat yellow; style ca. $1 \mathrm{~mm}$. long; nutlets ca. $3 \mathrm{~mm}$. long (excluding the spines), usually 2 or 3 nutlets covered with glochidiate spines to $4 \mathrm{~mm}$. long, the remaining ones with much shorter spines, or rarely, one nutlet muricate, lacking glochidia, and occasionally all 4 nutlets with spines essentially the same length.

It should be noted that fruits with dissimilar nutlets and fruits with nutlets alike sometimes occur on the same plant, and, in fact, the fruits on the type specimen of Lappula guatemalensis Brand (Seler \& Seler 3144) are variable, some fruits with nutlets that are all alike, others with only three nutlets maturing, two of these alike and the third much smaller with shorter spines.

Hackelia skutchii I. M. Johnston, Journ. Arn. Arb. 29: 238. 1948.

In meadows and on rocky slopes in open coniferous forests, 2,800 3,500 meters; Huehutenango. Apparently confined to the subalpine regions of the Sierra de los Cuchumatanes.

Erect, perennial herbs to $55 \mathrm{~cm}$. tall, the stems appressed-strigose; leaves appressed-strigose to strigillose on upper surface, appressed-strigillose to sericeous beneath, usually densely so, the midrib prominent, basal leaves oblanceolate, usually 6-14 cm. long, $0.5-1 \mathrm{~cm}$. wide, acute, mucronulate, attenuate to the base and of ten extending onto the petiole; cauline leaves narrowly oblanceolate to lanceolate, acute, mucronulate, sessile and rounded at the base, 1-6 cm. long, 0.2$0.6 \mathrm{~mm}$. wide, decreasing in size upward; cincinni many-flowered, lax, bracteate, usually forming an open panicle, the flowers pedicellate, the pedicels reflexing and becoming remote in age, longer than the calyx, ca. $1 \mathrm{~cm}$. long in fruit; calyx strigillose, ca. $1 \mathrm{~mm}$. long at anthesis, $2 \mathrm{~mm}$. long in fruit, the lobes ovate; corolla blue, tube ca. $2 \mathrm{~mm}$. long, limb 7-10 $\mathrm{mm}$. in diameter, the obovate lobes spreading; style ca. $0.5 \mathrm{~mm}$. long; nutlets 4 , grey, dissimilar, $2-2.5 \mathrm{~mm}$. long, usually 3 (2) nutlets muricate-papillate, the protuberances usually less than $0.3 \mathrm{~mm}$. long, glochidiate or not, and the remaining one (or 2) with glochidiate spines to $1.5 \mathrm{~mm}$. long.

The nutlets of $H$. skutchii are very similar to those of the Mexican $H$. leonotis I. M. Johnston. However, H. leonotis has a much smaller corolla (tube $1 \mathrm{~mm}$. long, limb $2.5-4 \mathrm{~mm}$. in diameter) and the indument of the stem and surface of the lower leaves is loose and somewhat shaggy.

\section{HELIOTROPIUM L.}

References: Ivan M. Johnston, The South American species of Heliotropium, Contr. Gray Herb. 81: 3-73. 1928; The Boraginaceae of northeastern South America, Journ. Arn. Arb. 16: 1-64. 1935; Studies in the Boraginaceae, XII, Journ. Arn. Arb. 18: 1- 


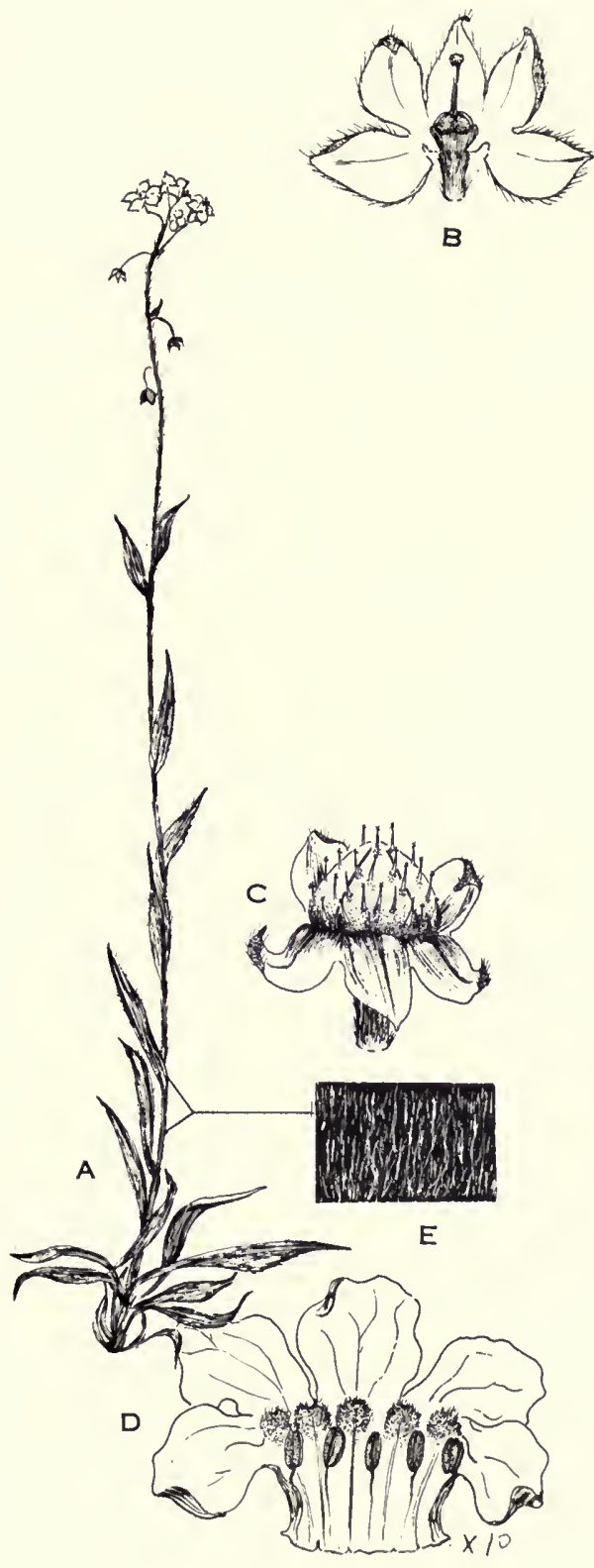

FIG. 25. Hackelia skutchii. A, habit, $1 / 2$ natural size; $B$, dissection of calyx showing pistil, $\times 5$; , accrescent caly $x$ with mature nutlets, $\times 5 ; \mathrm{D}$, corolla dissected to show stamens and faucal appendages, $\times 5$; E, pubescence from stem and leaves, much enlarged. 
25. 1937; Studies in the Boraginaceae, XVIII, Journ. Arn. Arb. 30 : 133-138. 1949.

Annual or perennial herbs, or sometimes low shrubs, usually pubescent, sometimes glabrous; leaves simple, alternate to subopposite; inflorescences usually of solitary, geminate or ternate bostryces, occasionally dichotomous, or the flowers solitary, cauline and internodal; calyx usually persistent but sometimes deciduous, with 5 teeth or lobes, the sepals often unequal in length and/or width; corolla small, usually white, sometimes blue, lavender or purple, rarely yellow, salverform or funnelform, 5-lobed, the tube cylindric, the limb spreading; stamens 5 , borne on the corolla tube, included, the filaments short; anthers ovate to oblong or lanceolate, obtuse, mucronate, or short-appendaged; ovary 4-celled, often 4lobate, the style terminal, the stigma sessile or borne on a distinct style, annular and peltate, turbinate, umbonate, or conic, the apex usually bearing a conic or cylindric or elongated sterile appendage, this often bifid; fruits dry, greenish to brown, sometimes lobate, at maturity separating into 2-4 bony nutlets; nutlets 1-2-seeded, often with 1-2 sterile cavities; endosperm thin; cotyledons flat.

A widely dispersed and diversified genus with perhaps 150 species in both hemispheres, chiefly in tropical regions, a few in temperate areas. In addition to the 14 species native to Guatemala, a Peruvian species, $H$. arborescens L., is cultivated in Guatemalan gardens at almost all elevations. It is grown because of the fragrance of its small, purple flowers, rather than for its value as an ornamental.

It is sometimes difficult to separate suffruticose plants of Heliotropium with furcate inflorescences (H. macrostachyum (DC.) Hemsl. and H. rufipilum (Benth.) I. M. Johnston) from Tournefortia, when fruiting material is not available.

Plants glabrous, the leaves succulent................. curassavicum. Plants pubescent, the leaves not succulent.

Flowers borne on ebracteate bostryces, these often dichotomous.

Leaves densely white-strigose or sericeous beneath, the, hairs all appressed.

Plants shrubby or suffruticose; veins strongly impressed on upper leaf surfaces; leaf blades usually acute; corolla glabrous in throat. . H. fallax.

Plants herbaceous; veins not impressed on upper leaf surfaces; leaf blades usually obtuse; corolla villous in throat............. procumbens.

Leaves green beneath, pubescent with spreading hairs or glabrate.

Leaf blades broadly ovate or deltoid-ovate, conspicuously undulate.

Corollas white, 9-10 $\mathrm{mm}$. long; inflorescence forked; fruits separating into 2 nutlets. ..................... macrostachyum.

Corollas normally pale blue or lavender, 4-5 mm. long; inflorescence simple; fruits separating into 4 nutlets............. indicum.

Leaf blades lanceolate to elliptic-oblong, not undulate.

Inflorescence of 2-3 times dichotomous cymes; calyx lobes accrescent, enclosing the fruits........................ rufipilum.

Inflorescence of solitary or geminate, elongating cincinni; calyx lobes not accrescent, never enclosing the fruits. 
Calyx 1-2 mm. long; indument of spreading, unequal hairs; fruits glabrous, minutely tuberculate............... angiospermum.

Calyx 3-4 mm. long; indument of largely malpighiaceous hairs; fruits puberulent, never tuberculate................ transalpinum.

Flowers borne in leaf axils, or if on bostryces, these bracteate, simple, solitary, never dichotomous.

Plants with stems prostrate or decumbent.

Flowers borne in or above the leaf axils.

Leaf blades $2 \mathrm{~mm}$. wide or less; fruiting calyx $2.5 \mathrm{~mm}$. long or less; fruits

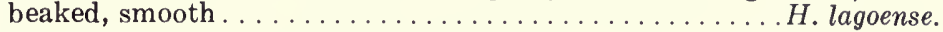

Leaf blades $3-7.5 \mathrm{~mm}$. wide; fruiting calyx $4-5 \mathrm{~mm}$. long; fruits not beaked, minutely reticulate-veined................ pringlei.

Flowers borne on terminal, short, usually dense cincinni. .H. foliosissimum. Plants with stems erect or ascending.

Bracts of inflorescence large and leaf-like. H. fruticosum.

Bracts of inflorescence small, inconspicuous, of ten subulate.

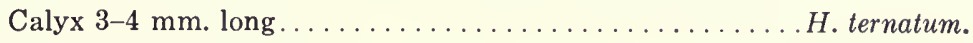
Calyx $0.8-1.5 \mathrm{~mm}$. long . ................. filiforme.

Heliotropium angiospermum Murray, Prodr. Stirp. Goett. 217. 1770. H. parviflorum L. Mant. Pl. 2: 201. 1771. Heliophytum parviflorum DC. Prodr. 9: 553. 1845. Cola de alacrán (Guatemala); cola de mico (Petén).

Wet or dry thickets, brushy fields, hillsides, sandbars, hedgerows or waste ground, 50-1,140 meters; Chimaltenango; Chiquimula; Guatemala; Izabal; Jalapa; Petén; Zacapa. Southern Mexico; British Honduras to El Salvador and Costa Rica; West Indies; South America.

Erect herbs, annual or perennial, to $1.5 \mathrm{~m}$. tall, branched, the branches slender, more or less hirsute with spreading, unequal hairs; leaves on slender petioles 5$15 \mathrm{~mm}$. long, of ten subopposite, the blades usually oblong-lanceolate or oblongelliptic, sometimes ovate to broadly lanceolate, 2-10 $\mathrm{cm}$. long, acute or short acuminate, usually acute at the base, sometimes rounded and decurrent, entire, usually thinly hirsute on both surfaces with 7-8 pairs of lateral veins; inflorescence of slender, pedunculate, ebracteate, solitary or geminate bostryces 6-22 cm. long, the flowers sessile, usually crowded; sepals lanceolate to oblong, obtuse or acute, 1-2 mm. long; corolla white, $2 \mathrm{~mm}$. long, barbate within throat; stamens subsessile, inserted on tube at a point just above the middle of the tube, anthers $0.8 \mathrm{~mm}$. long; stigma sessile, umbonate; ovary $0.2 \mathrm{~mm}$. long; fruits didymous, depressed, 1-1.5 mm. long, minutely tuberculate, the nutlets united in pairs.

This is a common, weedy plant in many parts of the Central American lowlands.

Heliotropium curassavicum L. Sp. Pl. 130. 1753; Johnston, Contr. Gray Herb. 81: 14. 1928. 
Saline or alkaline flats, plains and meadows, usually along seashores, sea level to 600 meters; Escuintla; Guatemala; Jutiapa; Retalhuleu; San Marcos. Southern United States; Mexico to Panama; West Indies; northern and western South America.

Plants annual or perennial, glabrous, succulent, bluish green and often glaucous, usually diffusely branched, the stems prostrate or decumbent, sometimes to $50 \mathrm{~cm}$. long or more; leaves sessile, the blades linear, linear-oblong, narrowly oblanceolate or spathulate, entire, obtuse, attenuate to the base, 1-5 cm. long; inflorescence of ebracteate bostryces, $1-10 \mathrm{~cm}$. long, solitary or geminate; the small flowers subsessile or on pedicels 1-2 mm. long; calyx 1-2 mm. long, the lobes triangular-ovate or oblong, acute or obtuse, usually shorter than the mature fruits; corolla white, 1-3 mm. long, the tube about equalling the sepals; anthers sagittate, 0.5-1 mm. long, sessile on tube; stigma broad, cap-like, sessile; fruits subglobose, separating into 4 oblong nutlets.

In Guatemala the plant occurs principally along the Pacific coast, where it is often abundant.

Heliotropium fallax I. M. Johnston, Journ. Arn. Arb. 18: 14. 1937. Hierba de toro (Huehuetenango).

Dry, open, brushy or forested, often rocky mountain slopes, frequently on limestone, 800-1,950 meters; Baja Verapaz; Jalapa; El Quiché; Huehuetenango. Southern Mexico.

Stout, erect shrubby or suffruticose plants, usually ca. $50 \mathrm{~cm}$. tall but sometimes attaining $120 \mathrm{~cm}$., branched, the branches densely tomentose or hirsute with long, white hairs; leaves subsessile or on petioles to $1 \mathrm{~cm}$. long, the blades elliptic to oblong-lanceolate or ovate-lanceolate, $1-5 \mathrm{~cm}$. long, $0.5-2 \mathrm{~cm}$. wide, usually acute, rarely obtuse, obtuse at the base and often abruptly contracted into the petiole, green or gray, densely white-hirsute or strigose above, the veins impressed, densely white-tomentose or strigose beneath; inflorescences terminal, pedunculate, ebracteate, of ten geminate bostryces $3-7 \mathrm{~cm}$. long; pedicels to $1 \mathrm{~mm}$. long; calyx white-strigose, the lobes narrowly or broadly lanceolate, acute or acuminate, 2 $3 \mathrm{~mm}$. long, surpassing the fruits; corolla white, $4-6.5 \mathrm{~mm}$. long, the tube surpassing the sepals, the lobes triangular to lanceolate, acute, strigose outside, glabrous within, the limb 3-4 mm. broad; stamens included, subsessile, inserted on tube at a point about midway from its base; the anthers $1.6 \mathrm{~mm}$. long, coherent at their apices; style ca. $0.1 \mathrm{~mm}$. long, stigma annular, the appendage elongated $1-1.3 \mathrm{~mm}$.; fruits subglobose, whitish-strigose, $1.5 \mathrm{~mm}$. long, $2.5 \mathrm{~mm}$. in diameter, separating into 4 nutlets.

This has been reported from Guatemala as $H$. coriaceum Lehm.

Heliotropium filiforme Lehmann, Goett. Gel. Anzeig. 1817: 1515. 1817; HBK. Nova Gen. \& Sp. $3: 86$ and 451, t. 204. 1818; DC. Prodr. 9: 545. 1845; I. M. Johnston, Contr. Gray Herb. 81:61. 1928. 
Open places, savannas, near sea level; Petén. Southern Mexico; British Honduras; Nicaragua; West Indies (fide Johnston); tropical South America.

Slender, erect, branching annuals, 10-40 $\mathrm{cm}$. tall, the stems and branches white-strigose; leaves on petioles 1-3 $\mathrm{mm}$. long, the blades oblanceolate or linearoblanceolate, obtuse or subacute, acute or attenuate to the base, 8-20 mm. long, $1.5-3.5 \mathrm{~mm}$. wide, strigose; inflorescences of solitary, slender bostryces, elongating in age, usually $2-15 \mathrm{~cm}$. long, bearing minute, lanceolate to linear-lanceolate, of ten subulate bracts and numerous flowers on pedicels $1 \mathrm{~mm}$. long or less; calyx $0.8-$ $1.5 \mathrm{~mm}$. long, the sepals lanceolate or linear-lanceolate, strigose, usually very unequal, surpassing the fuits; corolla white, 1-2 $\mathrm{mm}$. long, the limb $1.5-2 \mathrm{~mm}$. in diameter, the tube not surpassing the sepals; stamens sessile on tube, included, not at all coherent; stigma subsessile, ca. $0.3 \mathrm{~mm}$. long; fruits subglobose, obscurely 4-lobate, strigose, separating into 4 nutlets ca. $1 \mathrm{~mm}$. long.

A Nicaraguan specimen, F. E. Schramm (1926), has considerably longer, nearly shaggy hairs on leaves and stems, appearing almost velutinous rather than strigose.

Heliotropium foliosissimum Macbride, Proc. Am. Acad. 51: 541. 1916.

Open, grassy hillsides, about 2,000 meters; Huehuetenango. Southern Mexico.

Plants perennial, much branched from the base, the stems slender, hirsute, mostly $5-15 \mathrm{~cm}$. long, prostrate, densely leafy; leaves short-petiolate, the blades oblong-lanceolate or narrowly elliptic-oblong, $4-10 \mathrm{~mm}$. long, $1.5-3.5 \mathrm{~mm}$. wide, obtuse or acute, acute at the base, entire, sometimes revolute, strigose and with some longer, spreading hairs on margins and costae; inflorescences terminal, usually short and dense, the bracts large and foliaceous, the flowers pedicellate; calyx 3-3.5 mm. long, hirsute to pilose, the sepals oblanceolate to spatulate, acute or obtuse, nearly twice as long as the fruits; corolla white, the tube about equalling the calyx, the short lobes rounded, of ten somewhat crenate, the limb $3.5-5 \mathrm{~mm}$. broad; stamens included, subsessile, the anthers coherent at their apices; style evident, 0.5-1 mm. long; fruits depressed globose, somewhat strigillose, separating in to 4 nutlets.

Heliotropium fruticosum L. Syst. ed. 10, 2: 913.1759 and Amoen. Acad. 5: 394. 1759; I. M. Johnston, Contr. Gray Herb. 81: 66. 1928. H. campechianum HBK. Nova Gen. \& Sp. 3: 86. 1818. H. phyllostachyum Torr. Bot. U. S. \& Mex. Bound. 137. 1859. H. phyllostachyum var. erectum Macbride, Proc. Am. Acad. 51: 542. 1916. H. assurgens I. M. Johnston, Journ. Arn. Arb. 20: 375. 1939.

Damp or dry, open or brushy, often rocky plains and hillsides, 200-675 meters; Zacapa. Southern Mexico; British Honduras; Hon- 


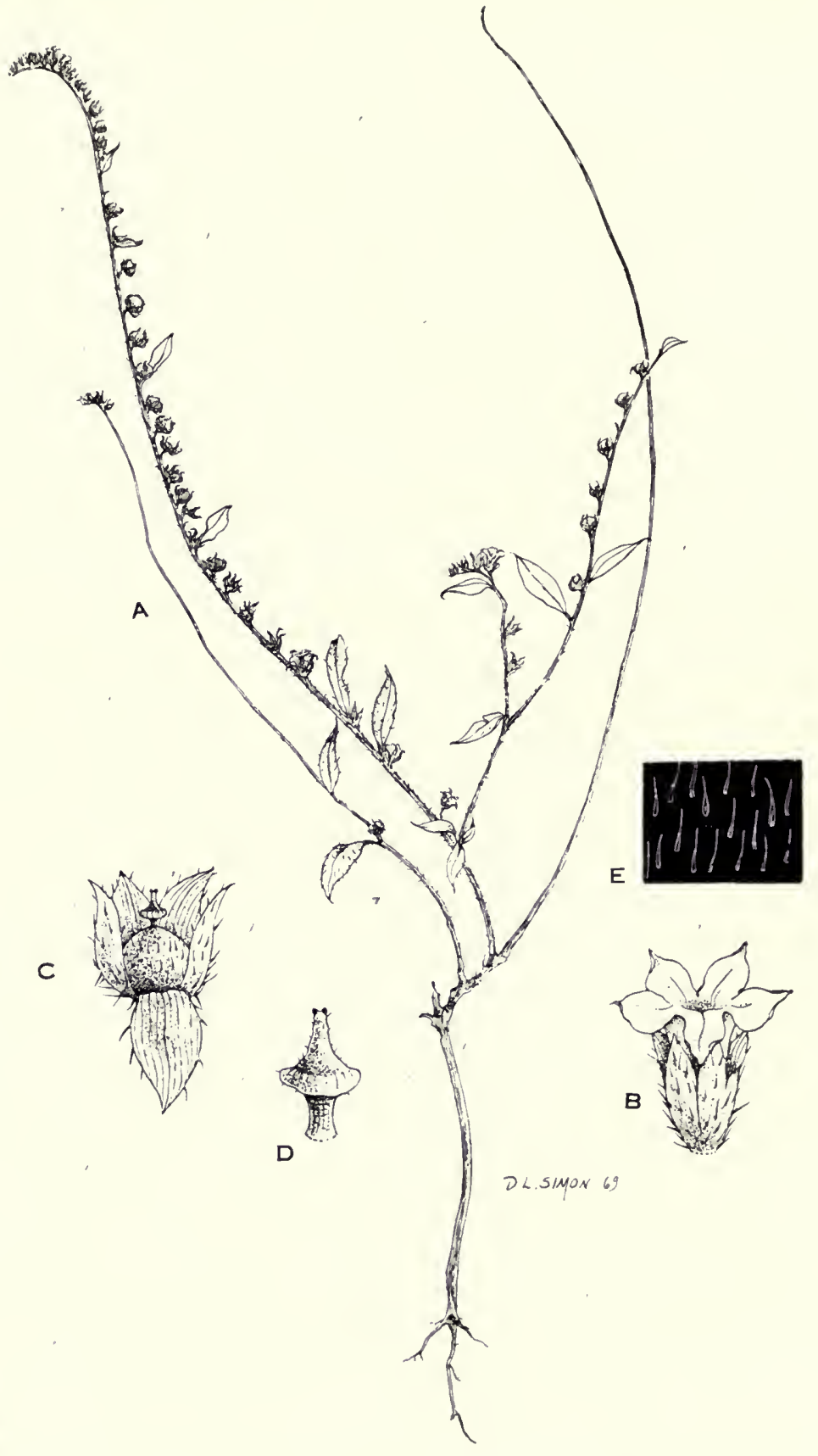

FIG. 26. Heliotropium fruticosum. A, habit, natural size; $\mathrm{B}$, flower, $\times 5$; $\mathrm{C}$, accrescent calyx with fruit, $\times 5 ; \mathrm{D}$, style and stigma, $\times 15 ; \mathrm{E}$, pubescence, much enlargeá. 
duras; El Salvador; Nicaragua; Costa Rica; West Indies; northern South America.

Slender, erect or ascending annuals, $8-30 \mathrm{~cm}$. tall, the branches strigose or appressed-pilose, usually leafy; leaves on petioles 1-4 mm. long, the blades small, $0.5-2.5 \mathrm{~cm}$. long, usually $0.4-0.6 \mathrm{~cm}$. wide, strigose on both surfaces, usually more densely so beneath, linear-oblong to oblong-lanceolate, lanceolate, or oblong-elliptic, apex usually acute, rarely obtuse, acute or attenuate to the base, the margins entire, of ten somewhat revolute; inflorescences of slender, elongating bostryces bearing scattered, large leaf-like bracts, the flowers sessile or on pedicels ca. $1 \mathrm{~mm}$. long, crowded at first but becoming remote (from 2 or 3 to as much as $10 \mathrm{~mm}$. apart); sepals lance-ovate to lanceolate, acute or subacute, strigose, unequal, $1.5-3 \mathrm{~mm}$. long, surpassing the fruits; corolla white, $2.5-3.5 \mathrm{~mm}$. long, the limb 3-4 $\mathrm{mm}$. across, the lobes broadly lanceolate, the tube equalling or exceeding the sepals at anthesis; stamens included, subsessile, inserted on lower half of tube, the anthers coherent at apices; style evident, at anthesis as long as or longer than the ovary, of ten persistent on the fruit, with the stigmatic disc and appendage still attached; fruits $1.5-2 \mathrm{~mm}$. in diameter, subglobose, strigose, separating into 4 nutlets about $1 \mathrm{~mm}$. long.

Heliotropium indicum L. Sp. Pl. 130. 1753. Cola de alacrán (Retalhuleu, Sacatepéquez); cola de zope (Santa Rosa); güegüecho (Jutiapa).

Usually in damp or wet thickets or fields, sandy river beds, sometimes on dry wasteland and along railways and roadsides, sea level to 1,200 meters; Alta Verapaz; Escuintla; Guatemala; Huehuetenango; Izabal; Jutiapa; Petén; El Progreso; Retalhuleu; Sacatepéquez; San Marcos; Santa Rosa; Zacapa. Florida; Mexico; British Honduras to Panama; West Indies; South America; naturalized in the Old World tropics.

Coarse, erect annuals to $1.5 \mathrm{~m}$. tall, the stems stout, branched, usually hispid with spreading whitish hairs; leaves on petioles 1-6 $\mathrm{cm}$. long, the blades usually broadly ovate to deltoid-ovate, sometimes lanceolate, 4-15 cm. long, acute or obtuse, mostly rounded or subcordate at the base and narrowly decurrent, repand or undulate, hispid and sericeous or variously pubescent; inflorescences of long, ebracteate, mostly solitary, simple bostryces to $28 \mathrm{~cm}$. long, the flowers sessile, crowded or remote; sepals linear-lanceolate, acute, $1.5-3 \mathrm{~mm}$. long, sparsely hispid with long hairs; corolla pale blue or lavender, the tube $3-4 \mathrm{~mm}$. long, more or less strigose outside, the lobes rounded, less than $1 \mathrm{~mm}$. long; style short but evident, ca. $0.5 \mathrm{~mm}$. long, stigma depressed-conic, ca. $0.5 \mathrm{~mm}$. long, ovary $0.8 \mathrm{~mm}$. long, stamens to $1 \mathrm{~mm}$. long, subsessile on tube at a point below the middle of tube, fruits deeply bilobate, mitriform, $2-3 \mathrm{~mm}$. long, glabrous, finally breaking into 4 angulate, beaked nutlets.

Heliotropium lagoense (Warm.) Gürke in Engler \& Prantl, Pflanzenf. IV, 3a: 97. 1893. Schleidenia lagoensis Warm. Kjoeb. 
Vidensk. Meddel 1867: 15. 1868. H. antillanum Urban, Symb. Ant. 4: 528. 1910. H. trinitense Urban, Symb. Ant. 7: 350. 1912.

Damp fields or savannas, 200 meters or less; Petén. Panama: Cuba and Puerto Rico; Trinidad; South America.

Plants annual or perennial, much branched from the base, the stems prostrate and often forming mats, sparsely appressed-hirsute; leaves small and numerous, mostly 3-8 mm. long, 1-2 mm. wide, lanceolate, linear-lanceolate, or lance-oblong, petiolate, obtuse or acute, acute at the base, entire, sparsely pilose or almost glabrous; flowers solitary in or above the leaf axils, on pedicels $2-4(-6) \mathrm{mm}$. long; sepals lanceolate or linear-lanceolate, unequal in width and in length, acute, sparsely hirsute to pilose, sometimes minutely papillose, ca. $1.5 \mathrm{~mm}$. long at anthesis, 2-2.5 mm. long in fruit; corolla white, ca. $3 \mathrm{~mm}$. long, the lobes $1 \mathrm{~mm}$. long, rounded; stamens included, subsessile on tube, the anthers coherent at their apices; stigma subsessile; fruits glabrous or sparsely strigillose, separating into 4 beaked nutlets, almost equalling the sepals in length.

Heliotropium macrostachyum (DC.) Hemsl. Biol. Centr. Amer. Bot. 2: 375. 1882. Heliophytum macrostachyum DC. Prodr. 9: 556. 1845. Cola de mico (Petén).

Brushy, rocky slopes and bordering lakes, 400-1,465 meters; Chiquimula; Guatemala; Petén; Zacapa. Mexico; Honduras; Nicaragua.

Erect herbs about $1 \mathrm{~m}$. tall, the stout branches densely pilose with soft, yellowish, spreading to somewhat reflexed, more or less viscid hairs; leaves on petioles 1-5 cm. long, the blades usually ovate to rounded-ovate, rarely lance-ovate, mostly 6-12 cm. long, rarely to $20 \mathrm{~cm}$. long, $4-10 \mathrm{~cm}$. wide, acute to acuminate, usually cordate to obtuse at the base, sometimes decurrent, undulate, sparsely or densely pubescent on both surfaces with spreading, more or less viscid hairs; inflorescences pedunculate, forked, the 2 branches $12-33 \mathrm{~cm}$. long, helicoid, many-flowered, the flowers crowded or remote, sessile; sepals linear-lanceolate, acuminate, hispidulous, 2-3 mm. long; corolla white, 9-10 mm. long, pilosulous outside, the lobes rounded, 1-1.5 mm. long; stamens included, the anthers subsessile at a point just above the middle of the corolla tube; style ca. $1 \mathrm{~mm}$. long, stigma depressed-discoid; ovary 4-celled, but 2 cells empty; fruit depressed-globose, $3 \mathrm{~mm}$. long, $4 \mathrm{~mm}$. broad, pilosulous, separating into 2 nutlets.

This species is much like Tournefortia in general appearance and has been confused with that genus in herbaria, especially when the specimens are not fruiting or bear immature fruits. It has also been confused with $H$. indicum L., although the inflorescences of $H$. indicum are never forked, its corollas are much shorter, and its fruits separate into four nutlets.

Heliotropium pringlei Robins., Proc. Am. Acad. 26: 170. 1891. Dry mountain slopes, 800-1,600 meters; Huehuetenango. Mexico. 
Slender annuals, prostrate or spreading, much branched, the stems $3-12 \mathrm{~cm}$. long, rather densely hirsute with long, spreading white hairs; leaves short-petiolate, the blades elliptic to elliptic-lanceolate or oblong lanceolate, sometimes nearly ovate, $7-15 \mathrm{~mm}$. long, $3-7.5 \mathrm{~mm}$. wide, acute or obtuse, acute at the base, thinly or densely white-hirsute; flowers short-pedicellate, borne in or above the leaf axils; sepals lanceolate, acute to acuminate, $2-2.5 \mathrm{~mm}$. long at an thesis, in fruit $4-5 \mathrm{~mm}$. long, ca. $2 \mathrm{~mm}$. longer than the fruits; corolla white, 4-5 $\mathrm{mm}$. long, the tube short, the lobes very short, triangular, the limb $3.5-5 \mathrm{~mm}$. broad; stamens included, subsessile below throat of tube, anthers coherent at their apices in early anthesis but separating later; style evident, at anthesis nearly as long as the ovary; fruits subglobose, minutely reticulate-veined, glabrate, separating in to 4 nutlets.

Heliotropium procumbens Mill. Gard. Dict. ed. 8, 10. 1768; Johnston, Contr. Gray Herb. 81: 52. 1928. H. americanum Mill. Gard. Dict. ed. 8, 11. 1768; Johnston, Contr. Gray Herb. 92: 89. 1930. H. inundatum Swartz, Prodr. Veg. Ind. Occ. 40. 1788; DC. Prodr. 9: 539. 1845. H. inundatum var. cubense DC. Prodr. 9: 540. 1845. H. rigidulum DC. l.c. H. eggersii Urban, Symb. Ant. 5: 481. 1908. Madre de alacrán (Guatemala); rabillo (Petén).

Wet to dry thickets, fields, mud flats, waste land, or sandbars along streams, sea level to 1,480 meters; Alta Verapaz; Guatemala; Izabal; Jutiapa; Petén; El Quiché; Retalhuleu; Santa Rosa. Southern United States; Mexico; El Salvador to Panama; West Indies; South America.

Plants usually annual, usually much branched from the base, decumbent, spreading, or ascending (rarely erect), strigose or appressed-pilose almost throughout, the hairs white or grayish, the stems $10-50 \mathrm{~cm}$. long, branched; leaves on petioles $3-18 \mathrm{~mm}$. long (commonly $4-10 \mathrm{~mm}$.), sometimes with 2 or 3 smaller leaves in the axil of an older leaf, the blades mostly $1-4 \mathrm{~cm}$. long and $0.5-2 \mathrm{~cm}$. wide, usually thin and soft, appressed-pilose to strigose, elliptic to obovate or broadly oblanceolate or (rarely) nearly linear, usually obtuse or rounded at the apex, rarely acute, sometimes minutely apiculate, acute to broadly cuneate at the base, entire, rarely revolute; inflorescences of mostly geminate or ternate, ebracteate, pedunculate bostryces, $2-10 \mathrm{~cm}$. long, the flowers sessile or on pedicels ca. $1 \mathrm{~mm}$. long; sepals unequal, lanceolate or linear, $0.5-1 \mathrm{~mm}$. long at anthesis, to $2.5 \mathrm{~mm}$. long in fruit, exceeding the fruits; corolla white, villous in throat, $1-1.5 \mathrm{~mm}$. long, the limb 1$1.4 \mathrm{~mm}$. in diameter; stamens included, subsessile on lower half of tube, the anthers not coherent at their apices; stigma sessile on the ovary; fruits subglobose, 4-lobate, strigillose, separating into 4 nutlets ca. $1 \mathrm{~mm}$. long.

A variable and weedy species often found where water has stood during the rainy season.

Heliotropium rufipilum (Benth.) I. M. Johnston, Contr. Gray Herb. 81: 44. 1928. Tournefortia rufipila Benth. Bot. Voy. Sulphur: 140. 1844. H. physocalycinum Donn.-Sm. Bot. Gaz. 49: 457. 1910. 
H. jalicense Macbr. Proc. Am. Acad. 51: 542. 1916. Cola de alacrán (Guatemala and Retalhuleu); cola de mico (Petén); hierba de alacran (Chiquimula and Jalapa); pie de shara (Chimaltenango, fide Morales); pie de gallo.

Damp or wet thickets, fields and slopes, along roadsides and in coffee plantations, 600-2,400 meters; Alta Verapaz; Chimaltenango; Chiquimula; Escuintla; Guatemala; Jalapa; Jutiapa; Petén; Retalhuleu; Sacatepéquez; Santa Rosa. Southern Mexico; El Salvador; Honduras; Nicaragua; Ecuador; Peru; Bolivia.

Erect herbaceous or suffruticose plants to $2 \mathrm{~m}$. tall, slender, branched, densely hispid and hirsute throughout with spreading brownish, often viscid or glandular hairs; leaves on petioles $0.5-2 \mathrm{~cm}$. long, the blades lanceolate or oblong-lanceolate, acute or acuminate, attenuate to the base, entire, $4-14 \mathrm{~cm}$. long; inflorescences of 2-3 times dichotomous cymes, the peduncles slender, the bostryces usually densely flowered, $5-15 \mathrm{~cm}$. long, ebracteate, the flowers sessile; calyx at anthesis $2.5-3 \mathrm{~mm}$. long, the sepals lanceolate to lance-ovate, of ten subulate, the mid-vein sometimes prominent, the calyx in fruit accrescent, assuming a pentagonal, subglobose form enveloping the fruit, the segments then broadly ovate, cuspidate-acuminate, ca. $4 \mathrm{~mm}$. long; corolla white, glandular-puberulent outside, the tube $2-3 \mathrm{~mm}$. long, the lobes semiorbicular, $1 \mathrm{~mm}$. long or less; stamens included, the anthers subsessile on the tube, about midway between its base and throat; style evident but less than $0.5 \mathrm{~mm}$. long; fruits glandular-puberulent, subglobose, separating into 4 nutlets ca. $1.5 \mathrm{~mm}$. long.

Heliotropium ternatum Vahl, Symb. Bot. 3: 21. 1794; I. M. Johnston, Journ. Arn. Arb. 30: 135. 1949. H. oaxacanum DC. Prodr. 9: 543. 1845. H. mexicanum Greenm., Proc. Am. Acad. 33: 484. 1898. Hierba de loro (Jutiapa); lorito blanco and pie de loro (Guatemala).

Usually dry, often rocky, brushy or open slopes, fields, hillsides, sometimes in pine-oak forests, rarely on sand bars, along streams or swampy meadows, 85-1,900 meters; Baja Verapaz; Chiquimula; Guatemala; Huehuetenango; Izabal; Jalapa; Jutiapa; El Quiché; Santa Rosa; Zacapa. Mexico to Costa Rica; Colombia; Venezuela.

A stout, erect shrub to $6 \mathrm{~cm}$. tall, or sometimes merely suffrutescent, branched, the branches densely strigose with white or grayish hairs; leaves alternate or subverticillate, sessile or on very short petioles, the blades lanceolate, linear-lanceolate or linear, mostly $1.5-3 \mathrm{~cm}$. long, $0.2-0.8 \mathrm{~cm}$. wide, usually acute to acuminate, rarely obtuse, acute at the base, subcoriaceous, revolute-margined, sparsely or densely white-strigose on both surfaces, sometimes pustulate or rarely only pitted or papillose on the upper surface; inflorescences of many-flowered bostryces, $2-15 \mathrm{~cm}$. long, bearing small, linear-lanceolate, sometimes subulate bracts, the flowers dense or remote, sessile or nearly so; calyx $3-4 \mathrm{~mm}$. long, white-strigose, the sepals lanceolate or ovate-lanceolate, acute, longer than the fruits; corolla white, strigose, the 
tube equalling or exceeding the calyx, the limb $3-4 \mathrm{~mm}$. broad; stamens included, the anthers coherent at their apices; style evident; fruits subglobose, separating into 4 strigose nutlets.

This plant has been known most commonly as $H$. fruticosum L., a name which has been found to apply properly to a quite different plant, treated on a preceding page.

Heliotropium transalpinum Vell. Fl. Flúm. 68, 1825 and Icones 2, t. 40. 1827. H. tiaridioides Cham. var. schizocarpum I. M. Johnston, Contr. Gray Herb. 81: 7. 1928.

Brushy slopes, thickets and along roadsides, 75-800 meters; Chiquimula; Izabal. Honduras; Costa Rica; Argentina; Bolivia; Brazil; Ecuador; Paraguay.

Erect, shrubby or suffruticose plants, 1-2 m. tall, branching, more or less pubescent throughout with largely malpighiaceous hairs; leaves of ten subopposite, on petioles $0.5-1 \mathrm{~cm}$. long, the blades entire, broadly lanceolate to oblong-elliptic, with 7-10 pairs of primary lateral veins, acute or acuminate, acute or attenuate to the base, $4-15 \mathrm{~cm}$. long, upper surface usually glabrescent but may be somewhat rough to the touch, lower surface with scattered pubescence, heaviest along the costae; inflorescence of elongated, simple, pedunculate, ebracteate, usually solitary bostryces to $20 \mathrm{~cm}$. long, the flowers sessile, crowded or remote; sepals linear or linear-lanceolate, acuminate, $3-4 \mathrm{~mm}$. long, usually equalling or surpassing the corolla tube, more or less strigillose; corolla white, $3-4 \mathrm{~mm}$. long, strigillose outside; stamens subsessile on tube, inserted at a point below the middle of the tube; anthers ca. $1 \mathrm{~mm}$. long; stigma sessile, conic; ovary ca. $1 \mathrm{~mm}$. long; fruits puberulent, depressed-globose, bilobate, the carpels sulcate, breaking first into two parts and finally into 4 nutlets.

Superficially much like $H$. angiospermum Murray, but readily separated by the malpighiaceous hairs, longer calyx lobes and the smooth, puberulent fruits.

\section{LITHOSPERMUM L.}

References: I. M. Johnston, Lithospermum, Contr. Gray Herb. 70: 18-31. 1924; A. Brand, Die amerikanischen Arten der Gattung Lithospermum in Fedde, Rep. Sp. Nov. 28: 10-17. 1930; I. M. Johnston, A survey of the genus Lithospermum, Journ. Arn. Arb. 33: 299362. 1952.

Mostly perennial herbs with rootstocks, usually with rough pubescence throughout; leaves alternate, entire; inflorescences of leafy or bracteate cincinni, these of ten elongating in age so that the flowers appear solitary in axils of leaves or bracts; calyx usually 5-parted, the sepals linear; corolla usually yellow or white in ours, small or large, in some species quite variable in size, the later flowers often much smaller and cleistogamous, funnelform or salverform, the tube straight, the 
throat of ten ampliate, sometimes gibbous or plicate, with or without intruding appendages, the 5 lobes imbricate, obtuse, spreading at anthesis; stamens 5 , included, the short filaments inserted on the tube, anthers oblong, obtuse or apiculate; ovary 4-lobed, seated on a flat gynobase; style filiform or stout, the 2 stigmas usually distinct; ovules erect; nutlets 4 or fewer by abortion, erect, ovoid, often very hard and bone-like, smooth or rugose; seeds straight, the cotyled ons flat.

About 40 species, chiefly in temperate regions of the northern hemisphere, in the tropics confined to the mountains.

Only the following four species are known from Central America.

Corollas white, appendaged within throat.

Lateral veins of leaves conspicuous; calyx in fruit 6-9 mm. long, 2-3 times longer than the nutlets............................. mediale.

Lateral veins of leaves essentially obsolete; calyx in fruit $3-4.5 \mathrm{~mm}$. long, little longer than the nutlets....................... distichum.

Corollas yellow, not appendaged within throat.

Corolla tubes usually 5-16 mm. long (in cleistogamous flowers only 1-3 mm.), the lobes conspicuously erose-dentate or crisped; nutlets smooth, white.

L. calycosum.

Corolla tubes $18-25 \mathrm{~mm}$. long, the lobes essentially entire; nutlets sulcate, gray-

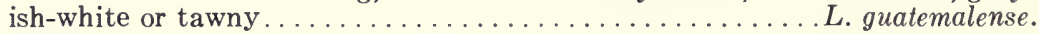

Lithospermum calycosum (Macbride) I. M. Johnston, Contr. Gray Herb. 70:30. 1924. L. strictum var. calycosum Macbride, Contr. Gray Herb. 48:56. 1916. L. obtusifolium I. M. Johnston, Contr. Gray Herb. 70: 27. 1924, new synonym. L. galeottii Brand in Fedde, Rep. Sp. Nov. 28: 17. 1930.

Open, grassy slopes, 1,350-2,800 meters; Huehuetenango. Mexico.

Coarse, erect perennials from thick, woody roots, the stems usually several, stout, simple or branched, strigose and hispid, sparsely or densely leafy; basal leaves attenuate to the base, oblanceolate, to $6 \mathrm{~cm}$. long, the cauline leaves sessile, linear-oblong to narrowly oblong, spatulate or oblong-lanceolate, usually obtuse, sometimes acute, usually obtuse at the base, strigose, of ten hispid, the lower ones often pustulate, the midvein usually prominent; inflorescences of simple or furcate, leafy cincinni, short at anthesis but elongating to as much as $20 \mathrm{~cm}$. in fruit, the pedicels 1-5 mm. long; calyx 6-8 $\mathrm{mm}$. long at anthesis, accrescent to as much as $15 \mathrm{~mm}$. in fruit, the sepals linear; corolla lemon-yellow, variable in size, the tube of early flowers of ten 10-16 mm. long, but the later ones sometimes only 1-3 mm. long and cleistogamous, pubescent outside, not appendaged within, the lobes 1.5$2 \mathrm{~mm}$. long, the margins erose-dentate to erose-lobulate or crisped; style usually about $7 \mathrm{~mm}$. long; anthers subsessile just below throat of tube; nutlets 4 or fewer, ovoid or broadly ovoid, $3-3.5 \mathrm{~mm}$. long, white, lustrous, smooth.

Lithospermum distichum Ortega, Hort. Matr. Dec. 1:8.1797; Johnston, Journ. Arn. Arb. 33: 361. 1952. L. spathulatum Mart. \& Gal. Bull. Acad. Brux. 11: 337. 1844. Spakúl (Huehuetenango). 
Usually on grassy slopes, open hillsides and alpine meadows, sometimes with Pinus rudis, 2,500-3,750 meters; Huehuetenango; Quezaltenango; Sacatepéquez. Mexico.

Perennials from woody, vertical roots, simple or sparsely branched, the stems erect or decumbent, 10-30 cm. tall, densely strigose; leaves numerous, the basal ones oblong-oblanceolate, attenuate to the base, to $8 \mathrm{~cm}$. long, the cauline ones usually oblong or oblanceolate, sometimes lanceolate, usually obtuse at the apex, acute or attenuate to the base or broad and somewhat clasping, minutely strigose on both surfaces, the lateral veins obsolete or nearly so; inflorescences of several terminal cincinni, the flowers few or many, pedicellate, the branches in age elongating and the flowers then remote; calyx at anthesis $2-3 \mathrm{~mm}$. long, in fruit 3$4.5 \mathrm{~mm}$. long; corolla white, the length varible, usually $5-7 \mathrm{~mm}$. long, rarely to $10 \mathrm{~mm}$. long, puberulent outside, glabrous within, the faucal appendages well developed; anthers subsessile on the tube, inserted at a point $1-1.5 \mathrm{~mm}$. below the throat; style $2-3 \mathrm{~mm}$. long; nutlets $2-2.5 \mathrm{~mm}$. long, ovoid or broadly ovoid, white, lustrous, smooth.

\section{Lithospermum guatemalense Donn.-Sm., Bot. Gaz. 27: 436. 1899.}

At 1,400-1,800 meters; Huehuetenango (type from Trinidad, Seler \& Seler 3082); also collected between Chaculá and Canquintic. Mexico (Chiapas).

Stout, erect perennials to $45 \mathrm{~cm}$. tall, from thick, woody roots, the stems several, simple below the inflorescence, densely leafy, densely hirsute or hispid with white, more or less spreading hairs; basal leaves not seen, cauline leaves sessile, linear-lanceolate to lance-oblong, strongly ascending or suberect, acute, obtuse or acute at the base, hispid, the veins conspicuous; cincinni few-flowered, densely leafy, the flowers short-pedicellate; calyx at anthesis $7-9 \mathrm{~mm}$. long, accrescent, 10-12 mm. long in fruit, the sepals linear, hispidulous; corolla yellow, the tubes 18-25 mm. long, pubescent outside, not appendaged within, the broad lobes 2.5$3 \mathrm{~mm}$. long; anthers subsessile, inserted on tube at a point $2-3 \mathrm{~mm}$. below the throat; style filiform, exserted 1-2 mm.; nutlets ovoid, $3.5-4 \mathrm{~mm}$. long, grayishwhite or tawny, lustrous, conspicuously sulcate and sparsely pitted.

Lithospermum mediale I. M. Johnston, Contr. Gray Herb. 70: 28. 1924. L. discolor var. subviride Kuntze, Rev. Gen. 2: 439. 1891. L. colombianum Brand in Fedde, Rep. Sp. Nov. 28: 16. 1930. Chichavac (Chimaltenango).

Open, grassy or rocky hillsides, thickets, brushy or forested slopes, often in oak and pine-oak forest, rarely on roadside banks, 1,4002,800 meters; Chimaltenango; Huehuetenango; Jalapa; Quezaltenango (type: Seler \& Seler 2893); El Quiché; Sacatepéquez; Santa Rosa; Sololá. Colombia and Venezuela. 


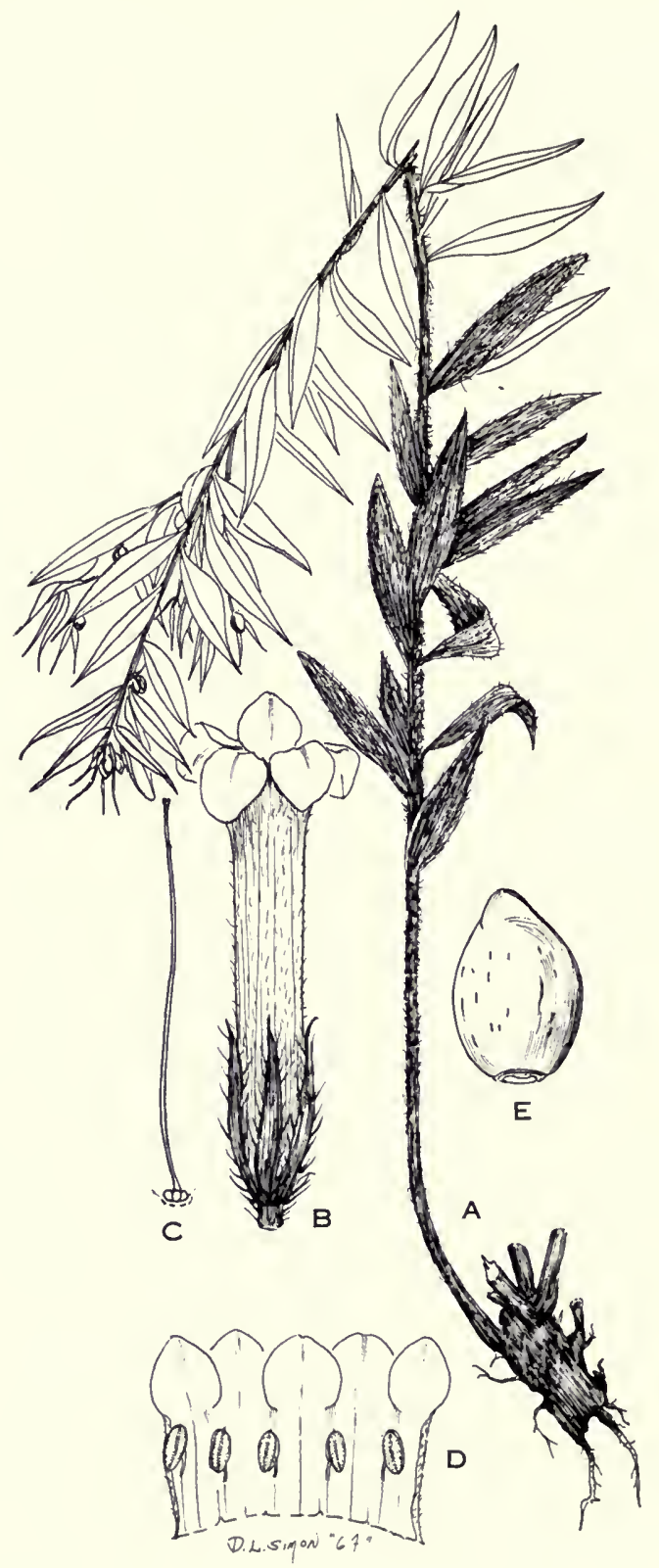

FIG. 27. Lithospermum guatemalense. A, habit, 1/2 natural size; B, flower, $\times 11 / 2 ; C$, pistil, $\times 1 \frac{1}{2} ; \mathrm{D}$, dissection of apex of corolla showing stamens, $\times 2$; $\mathrm{E}$, nutlet, $\times 5$. 
Stout perennials, usually erect, rarely decumbent, $30-90 \mathrm{~cm}$. tall, from thick, woody roots, usually branched above, the stems strigose, often somewhat hispid; leaves numerous, mostly ascending, the basal leaves oblong-lanceolate, attenuate to the base, to $10 \mathrm{~cm}$. long, the cauline leaves sessile or subsessile, the blades oblong to lanceolate or oblanceolate, the lower ones to $7.5 \mathrm{~cm}$. long, of ten to $2 \mathrm{~cm}$. wide, the upper ones 1-3 cm. long, $0.4-1 \mathrm{~cm}$. wide, strigose, of ten pustulate, the veins usually conspicuous; inflorescences terminal, the branches solitary, geminate, or ternate, the flowers on short, thick pedicels, usually exceeded by the subtending leaves; calyx 2-3 mm. long at anthesis, 6-9 mm. long in fruit, the sepals linear; corolla white, the tube 5-6 mm. long, pubescent outside, glabrous within, the appendages within the throat well developed, the lobes rounded, minutely erose, 1-2 mm. long; the anthers subsessile on tube, inserted at a point ca. $2 \mathrm{~mm}$. below the throat; style $3-4 \mathrm{~mm}$. long; ovary ca. $1 \mathrm{~mm}$. long; nutlets $2-3$, ovoid, $2.5-$ $3.5 \mathrm{~mm}$. long, white, lustrous, smooth.

\section{This has been reported from Guatemala as L. discolor Mart. \& Gal.}

\section{MACROMERIA D. Don}

References: D. Don, Edinb. Phil. Journ. 239. 1832; A. DeCandolle, in DC. Prodr. 10: 68. 1846.

Erect, perennial, herbaceous or suffruticose plants, usually tall and coarse, pubescent and of ten hispid; leaves alternate, the lateral veins oblique; inflorescences terminal on the branches, the flowers solitary and extra axillary from near the bases of leaves or leaf-like bracts, the cincinni short at first, in age usually more or less elongated, the flowers sessile or pedicellate (ours), conspicuous; calyx 5-parted, the segments linear; corolla yellow, whitish, or greenish, the tube elongated, usually dilated above, naked within, the 5 lobes imbricate in bud, spreading at anthesis; stamens 5, exserted, the filaments inserted on the tube, filiform; anthers oblong or linear, muticous, versatile; ovary 4-lobate, the lobes subglobose, inserted upon a flat gynobase; style filiform, exserted, the stigma small; ovules suberect; nutlets by abortion mostly 1-2, ovoid, erect; seeds straight, the cotyledons flat.

About a dozen species, ranging from southwestern United States to Peru. Only one is found in Central America.

Macromeria guatemalensis I. M. Johnston, Journ. Arn. Arb. 29: 232. 1948. Itamo real (San Marcos); té de monte (Huehuetenango).

Dry, forested upper slopes, 2,400-3,900 meters; Huehuetenango; San Marcos.

Erect, suffruticose perennials to $2 \mathrm{~m}$. tall, much branched, the stems and branches scabrous; leaves subsessile, the blades lanceolate to linear-lanceolate, $2.5-5 \mathrm{~cm}$. long, $0.5-1.5 \mathrm{~cm}$. wide, attenuate, rounded to acute at the base, the margins narrowly revolute, veins and costae impressed above, evident below, both 


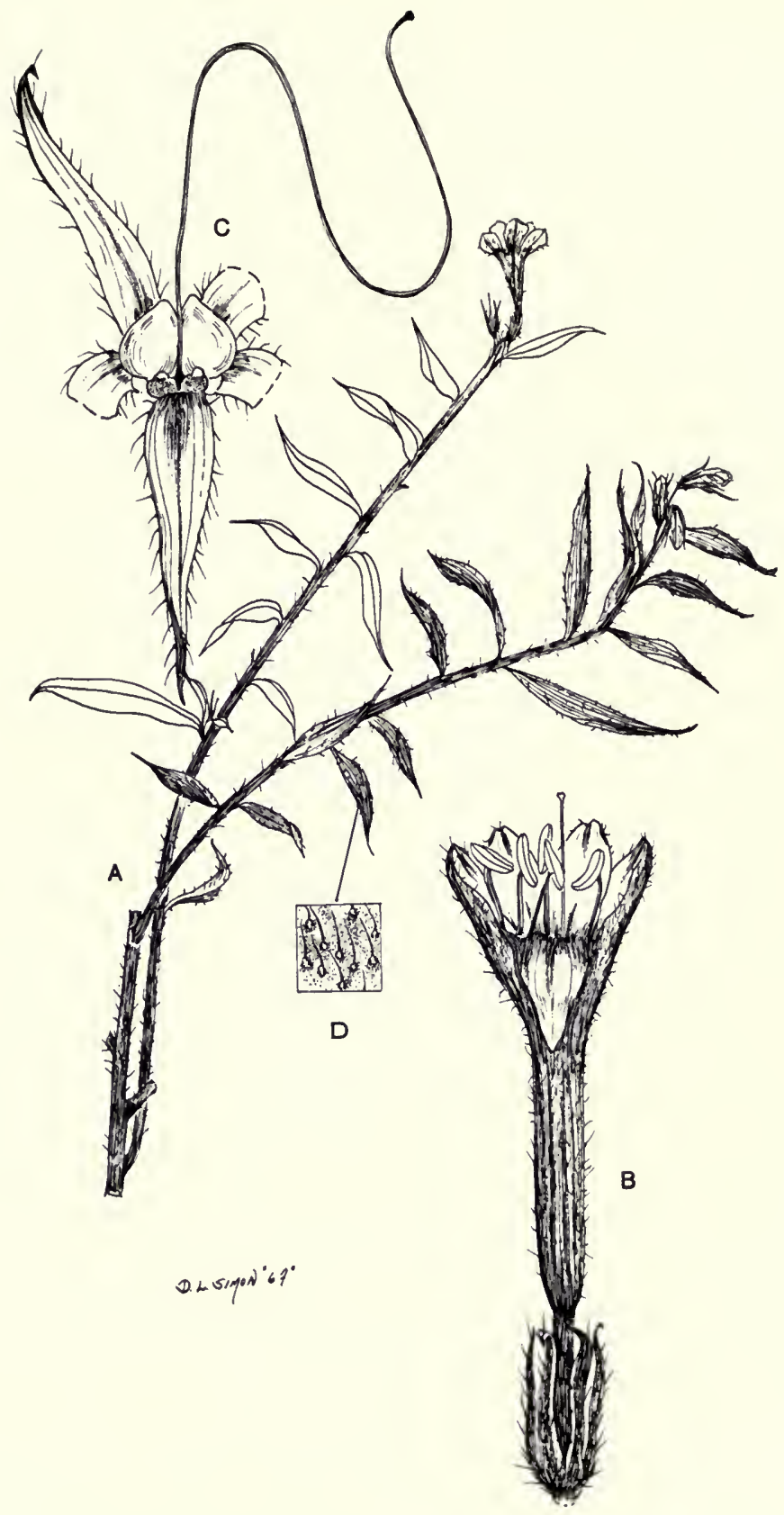

FIG. 28. Macromeria guatemalensis. A, habit of plant, $1 / 2$ natural size; $\mathrm{B}$, flower, $\times 2 ; \mathrm{C}$, dissection showing gynobasic style, two mature fruits which are joined, two aborted ovules, and accrescent calyx lobes, $\times 3 ; \mathrm{D}$, pubescence with enlarged bases, much enlarged. 
surfaces scabrous, the indument of abundant, rigid, tuberculate, appressed hairs; inflorescences terminal on the branches, the flowers solitary and extra axillary from near the bases of leaves or leaf-like bracts; flowers on pedicels $3-10 \mathrm{~mm}$. long; calyx at anthesis $7-10 \mathrm{~mm}$. long, in fruit 11-15 mm. long, the sepals linear, unequal in length, prominently ribbed, pilose to strigose; corolla pale yellow, ca. $3.5 \mathrm{~cm}$. long, hirsute outside, glabrous within, basal part of tube ca. $10 \mathrm{~mm}$. long and 1-1.2 mm. thick, abruptly expanded upward, the upper part cylindrical, ca. $17 \mathrm{~mm}$. long and $5 \mathrm{~mm}$. wide, the lobes triangular, 6-8 $\mathrm{mm}$. long, rounded at apex; stamens exserted, the filaments $4-7 \mathrm{~mm}$. long, affixed to tube at a point ca. $3 \mathrm{~mm}$. below throat, anthers 2.5-3 mm. long; style filiform, exserted; nutlets ovoid, ca. $3 \mathrm{~mm}$. long, white, lustrous, smooth.

Fruits sometimes used for beads.

\section{ROCHEFORTIA Swartz}

References: M. Gürke, in Engler \& Prantl, Pflanzenf. 4(3a): 89. 1893; I. Urban, Symb. Ant. 5: 479. 1908.

Dioecious shrubs, small trees, or woody vines, usually much branched, sometimes armed with spines; leaves alternate or fasciculate, entire, petiolate, the blades variously pubescent; inflorescences cymose or the flowers solitary; flowers small, sessile or pedicellate; calyx lobes $4-5$, imbricate; corolla rotate, the tube very short; stamens $4-5$, exserted, the filaments of staminate flowers about equalling the anthers in length, those of pistillate flowers shorter, the anthers ovoid, introrse; disk thick; ovary bilocular or 4-locular, the ovules 4; styles 2, terminal, those of the pistillate flowers filiform, those of the staminate flowers subulate, the stigmas hirsute, dilated or flattened, fruits drupaceous, carnose, more or less globose, containing 4 pyrenes.

Species five or six, all except the following in the West Indies and northern South America.

Rochefortia lundellii Camp in Lundell, Contr. Univ. Mich. Herb. 7: 47. 1942.

Known only from the type, British Honduras, El Cayo District, Arenal-Valentín Road, in high forest, C. L. Lundell 616\%.

Woody vine, the branches slender, sparsely armed with rather blunt spines 2-6 mm. long, the bark gray; leaves fasciculate on short spurs, the petioles slender, to $12 \mathrm{~mm}$. long, glabrous in age, the blades coriaceous, pale, glabrous, cuneate obovate to ovate, rounded or obtuse at apex, $3-7 \mathrm{~cm}$. long, $1.5-3 \mathrm{~cm}$. wide, attenuate to the base, entire, with usually 5-7 (rarely 8-9) pairs of veins; inflorescences appressed-pubescent to glabrate, the cymes to $2 \mathrm{~cm}$. long, 2-6 flowered; calyx sparsely appressed-pubescent, the 5 lobes imbricate, ovate or suborbicular, obtuse, 1.5-2.5 mm. long, ciliate, slightly accrescent in fruit; corolla glabrous, the tube $1 \mathrm{~mm}$. long, the lobes reflexed, oblong-elliptic to broadly ovate, 2-3 mm. long, rounded at the apex; stamens 5 , alternate with the corolla lobes, the filaments inserted at the apex of the corolla tube, the anthers oblong, sagittate; ovary glabrous, 4 -celled; styles 2 ; fruits globose, lustrous, $5-7 \mathrm{~mm}$. in diameter. 


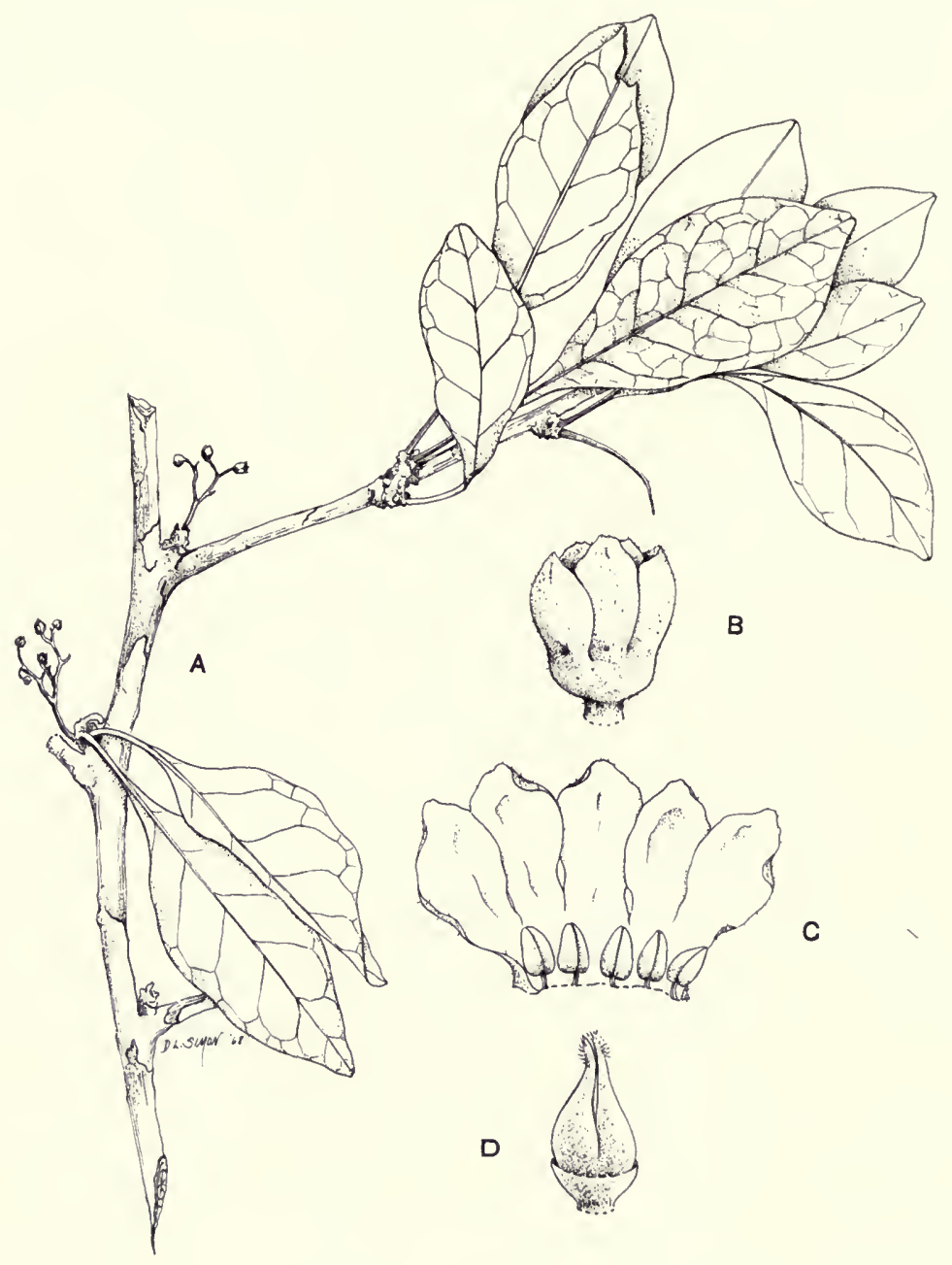

FIG. 29. Rochefortia lundellii. A, habit of plant, natural size; B, calyx, $\times 10$; $\mathrm{C}$, corolla opened to show stamens, $\times 10 ; \mathrm{D}$, staminate pistil, $\times 10$.

A staminate plant from Petén, Tikal National Park, Lundell 17593, has been identified by other workers as R. lundellii. However, the type specimen is described as a woody vine and according to label data, the Petén collection is a "slender tree, 2 " diam., $20 \mathrm{ft}$. high ..." Further, it does not appear very different from some Antillean collections of the variable $R$. spinosa (Jacq.) Urban, although 
the petioles of our plant are considerably longer. If additional material becomes available it may be possible to place it correctly.

\section{TOURNEFORTIA L.}

References: Linnaeus, Gen. 68. 1754; A. de Candolle, in DC. Prodr. 9: 512-531. 1845; Ivan M. Johnston, Observations on the species of Cordia and Tournefortia known from Brazil, Paraguay, Uruguay, and Argentina, Contr. Gray Herb. 92: 3-89. 1930; The Boraginaceae of northeastern South America, Journ. Arn. Arb. 16:1-64. 1935; Boraginaceae of the Southern West Indies, Journ. Arn. Arb. 30: 111-138. 1949 .

Shrubs to weak trees or woody vines, glabrous or pubescent; leaves alternate, entire; inflorescences consisting of dichotomous helicoid cymes or the repeatedly dichotomous bostryces borne in panicles; calyx persistent, usually 5-lobate, one sepal of ten longer than the others; corolla white, yellow or greenish, small, usually 5lobate, the tube cylindric, the limb spreading; stamens usually 5, borne on the corolla tube, included, the filaments short; ovary 4-celled, sometimes 4-lobate, the style solitary, terminal, usually bifid at apex, the stigma annular or conic; fruit drupaceous, entire or lobate at maturity, when dry separating into $2-4$ bony nutlets, these 1-2-seeded, or with 1-2 empty cavities; endosperm thin; cotyledons flat.

A genus of wide range and much diversification, presenting many problems in delimitation. There are perhaps 100 species in the tropics of both hemispheres, most numerous in America, with about 25 species in Mexico and Central America. Thirteen occur in Guatemala. The altitudinal range of the genus is very wide, often extending from sea level to 3,600 meters.

Sepals 6-9 $\mathrm{mm}$. long.

Inflorescence dense, compact; corolla lobes $0.5-2 \mathrm{~mm}$. long, obtuse; style short, not more than one-third the length of corolla tube......... densiflora.

Inflorescence open, lax; corolla lobes 3-4.5 mm. long, acute; style elongated, almost equalling corolla tube . . . . . . . . . . . . . . . . . . . Sepals less than $6 \mathrm{~mm}$. long.

Corolla tubes $10-12 \mathrm{~mm}$. long. ........................

Corolla tubes less than $10 \mathrm{~mm}$. long.

Style at anthesis shorter than sepals.

Corolla lobes $3-4.5 \mathrm{~mm}$. long.

Leaves linear or linear-spatulate............. gnaphalodes.

Leaves lance-oblong or lance-elliptic . . . . . . . . . longiloba. Corolla lobes 1-2 mm. long.

Sepals equalling or two-thirds as long as corolla tube......T. belizensis.

Sepals less than two-thirds as long as corolla tube.

Leaves and stems glabrous or nearly so; if hairs present, these usually appressed; leaf blades essentially smooth to the touch; fruits usu-

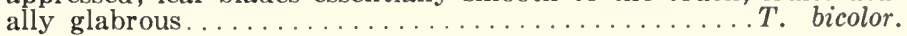


Leaves and stems abundantly hirsute or hirtellous with short, curved hairs, or if leaf blades glabrate or only sparsely strigose, then rough to the touch; fruits usually hispid............ T. hirsutissima.

Style at anthesis equalling or longer than sepals.

Woody vines; fruits conspicuously lobate; anthers usually adherent at their apices.

Corolla tubes $3-4 \mathrm{~mm}$. long; mature leaves usually essentially glabrous beneath; sepals usually ovate-lanceolate. ..........T. maculata.

Corolla tubes $1.5-2.5 \mathrm{~mm}$. long; mature leaves usually densely sericeous or tomentose beneath; sepals linear-lanceolate........T. volubilis.

Shrubs or small trees; fruits not lobate; anthers free from each other.

Corolla tubes 4-6 mm. long; sepals $2-4 \mathrm{~mm}$. long.

Corolla lobes ovate or lanceolate, acute, usually less than $2 \mathrm{~mm}$. long.

Corolla lobes narrowly triangular, acuminate, $2-3 \mathrm{~mm}$. long.

T. petiolaris.

T. acutiflora.

Corolla tubes 3-4 mm. long; sepals less than $2 \mathrm{~mm}$. long. .... T. glabra.

Tournefortia acu tiflora Mart. \& Gal. Bull. Acad. Brux. 11(2): 333. 1844.

Usually in damp or wet thickets or forests, rarely on dry, forested slopes, 1,500-3,400 meters; Chimaltenango; Huehuetenango; Jalapa; San Marcos; Zacapa. Southern Mexico; Honduras.

Shrubs or small trees, to $8 \mathrm{~m}$. tall, the branches usually stout, densely browntomentose; leaves on petioles $1-8 \mathrm{~cm}$. long, the blades usually ovate-oblong to elliptic-oblong, rarely broadly obovate, acute or acuminate, rounded to acute at the base, or abruptly contracted and narrowly decurrent, mostly $8-25 \mathrm{~cm}$. long, 4$12 \mathrm{~cm}$. wide, usually densely and softly velutinous-pilose on both surfaces or strigose above and velutinous beneath, but may be glabrous or glabrate on both surfaces, inflorescences usually lax, bostryces few, the flowers sessile or subsessile, usually 1$3 \mathrm{~mm}$. apart; sepals linear to linear-lanceolate, often subulate, strigillose, $2.5-4 \mathrm{~mm}$. long; corolla yellow-green or greenish, the tube strigillose outside, ca. $5 \mathrm{~mm}$. long, the lobes linear-lanceolate, acuminate, recurved, $2.5-3 \mathrm{~mm}$. long; stamens inserted in throat of tube, the anthers $1.5-2 \mathrm{~mm}$. long; style elongated, surpassing calyx segments at anthesis and reaching a point just below the anthers; fruits ovoid to subglobose, glabrous, white, ca. $1 \mathrm{~cm}$. in diameter.

Tournefortia angustiflora Ruiz \& Pavón, Fl. Peruv. 2: 25, t. 151.1799.

Damp thickets and forest, often on banks along streams, 150 600 meters; Escuintla; Santa Rosa. Honduras to Panama; South America.

Weak, often subscandent shrubs, to $4 \mathrm{~m}$. tall, the young branches slender, sparsely short-hispidulous or almost glabrous; leaves short-petiolate, the blades ovate-lanceolate to elliptic or oblanceolate, acute or acuminate, acute or attenuate to the base, rarely obtuse and abruptly decurrent, essentially glabrous, sometimes sparsely hispidulous beneath along the costa, densely and finely papillose, mostly 
7-18 cm. long, with 5-7 pairs of primary lateral veins; inflorescences of dichotomous cymes, the nearly straight or only slightly helicoid cymes usually not more than $10 \mathrm{~cm}$. long, of ten densely flowered, the flowers subsessile to short pedicellate, erect or nearly so; calyx short, the sepals broadly ovate, $1-1.5 \mathrm{~mm}$. long, usually densely papillose, minutely strigillose or almost glabrous; corolla greenish white, the tube slender, narrowed upward, sparsely and minutely strigillose outside, 10-12 mm. long, the lobes broadly ovate, short, rounded or obtuse and apiculate; stamens inserted below mid-tube, the anthers ca. $2 \mathrm{~mm}$. long; style very short, the stigma almost sessile on the ovary; fruits globose or globose-ovoid, white, glabrous.

Tournefortia belizensis Lundell, Bull. Torr. Bot. Club 69: 399 . 1942.

Thickets and forest, 150-1,800 meters; Chiquimula; Petén. British Honduras.

Shrubs to $3 \mathrm{~m}$. tall, the young branches hirtellous; leaves subsessile or shortpetiolate, the blades lance-oblong or elliptic-oblong, acute or acuminate, cuneate or attenuate to the base, hirtellous on both surfaces, mostly $5-12 \mathrm{~cm}$. long, $2-4 \mathrm{~cm}$. broad; inflorescences pedunculate, small or large, the bostryces usually $6-12 \mathrm{~cm}$. long, the flowers sessile, ca. $2 \mathrm{~mm}$. apart; sepals linear to linear-lanceolate, acute, hirtellous, 2.5-4 mm. long; corolla white or greenish, the tube $3-4.5 \mathrm{~mm}$. long, strigillose outside, the lobes linear or triangular and acuminate, spreading, 1-2 mm. long; stamens sessile, inserted just above mid-tube, anthers $1 \mathrm{~mm}$. long or less; style at anthesis not exceeding calyx; fruits ovoid to depressed-globose, glabrous, white, ca. $5 \mathrm{~mm}$. in diameter.

This may prove to be a form or variety of T. umbellata HBK. of the West Indies and the Yucatan Peninsula, Mexico, as it differs only in vesture. The branches, stems, leaves, and calyces of T.umbellata are glabrous or nearly so, and the leaf blades are sometimes scaberulous.

Tournefortia bicolor Swartz, Prodr. Veg. Ind. Occ. 40. 1788; Johnston, Contr. Gray Herb. 92: 69. 1930 and Journ. Arn. Arb. 16: 49. 1935. T. laevigata Lam. Encycl. 1: 416. 1791. T. nitida HBK. Nova Gen. \& Sp. 3: 84. 1819. T. laevigata var. latifolia DC. Prodr. 9: 519. 1845.

Damp or wet thickets or forest, sometimes in mangrove swamps, sea level to 1,500 meters; Alta Verapaz; Huehuetenango; Izabal; Quezaltenango; Sacatepéquez; San Marcos. Southern Mexico to Panama; West Indies; tropical South America.

Large shrubs to $5 \mathrm{~m}$. tall, of ten subscandent, the branches almost glabrous or with scattered, weak appressed hairs; leaves on petioles 1-2 cm. long, the blades ovate to elliptic, lance-ovate or lance-oblong, $5-15 \mathrm{~cm}$. long, 3-9 cm. broad, usually rather thick and firm, acute to acuminate, usually obtuse or rounded (rarely acute) at the base, nearly glabrous or with scattered, appressed hairs on one or both sur- 
faces; inflorescences usually dense and much branched, small or large, the bostryces short, the flowers sessile; sepals ovate or ovate-lanceolate, acute, 1-2 mm. long (rarely to $3.5 \mathrm{~mm}$.), sparsely and minutely strigose; corolla white, the tube strigillose outside, usually 4-6 $\mathrm{mm}$. long (rarely to $8 \mathrm{~mm}$.), the lobes obtuse, usually apiculate; stamens inserted about mid-tube, the anthers $1.5-2 \mathrm{~mm}$. long; stigma subsessile on ovary; fruits white, subglobose, glabrous, ca. $6 \mathrm{~mm}$. long when dry.

Tournefortia densiflora Mart. \& Gal. Bull. Acad. Brux. 11(2): 333. 1844. T. scholastica Standl. \& L. Wms., Ceiba 3: 56. 1952. Chompipito (Guatemala).

Damp thickets to dry mountain slopes, 120-1,400 meters; Guatemala; Huehuetenango; Jalapa; Jutiapa; El Progreso; El Quiché; Zacapa. Mexico; Honduras.

Erect shrubs to $2 \mathrm{~m}$. tall, the branches terete, usually short-hirsute; leaves on petioles 1-4 cm. long or the upper leaves sometimes subsessile, the blades lanceolate to ovate or elliptic, $4-20 \mathrm{~cm}$. long, acute or acuminate, of ten attenuate to the base, sometimes acute, rarely rounded and somewhat abruptly decurrent (usually the older leaves on lower stems), scabrous on both surfaces or scabrous above and softly pubescent beneath; inflorescences long-pedunculate, the densely-flowered bostryces few or rather numerous, usually less than $8 \mathrm{~cm}$. long; calyx $6-9 \mathrm{~mm}$. long, the sepals linear, erect, densely hispidulous; corolla white, the tube densely hispidulous outside, 7-9 mm. long, the lobes ovate, acute or obtuse, of ten somewhat crenate; stamens inserted about mid-tube, the anthers $2 \mathrm{~mm}$. long; style short, rising to about one-third the length of tube; fruits globose-ovoid, sparsely hispidulous or glabrous, ca. $6 \mathrm{~mm}$. long when dry.

Apparently closely related to T. mutabilis Vent. of Mexico, which includes $T$. hartwegiana Steud. and probably $T$. trichocalycina DC. and T. capitata Mart. \& Gal. All of these are variable in quantity of indument, and all have sepals shorter than those of $T$. densiflora, usually about half (rarely two-thirds) as long as the mature corolla tube.

T. calycina Benth., also of Mexico, may be separated from all of these by its broader, oblanceolate to spatulate sepals; in addition, the few specimens I have seen appear to be uniformly scabrous.

Tournefortia elongata D. Gibson, Fieldiana: Botany, 32: 65, f. 1. 1969. Yerba coche (Jalapa).

Upper volcanic slopes, wet, mixed broadleaf and cypress forest, cloud forest, damp second-growth thickets, rarely in hedgerows on upper slopes, 1,800-3,600 meters; Chimaltenango; Escuintla; Guatemala; Jalapa; El Progreso; Quezaltenango; El Quiché; San Marcos; Sololá: Totonicapan. Mexico (Chiapas).

Shrubs or small trees to $8 \mathrm{~m}$. tall, the branchlets densely brown hirsute or hirsute-tomentose; leaves on stout, tomentose petioles mostly $0.5-4 \mathrm{~cm}$. long, the 


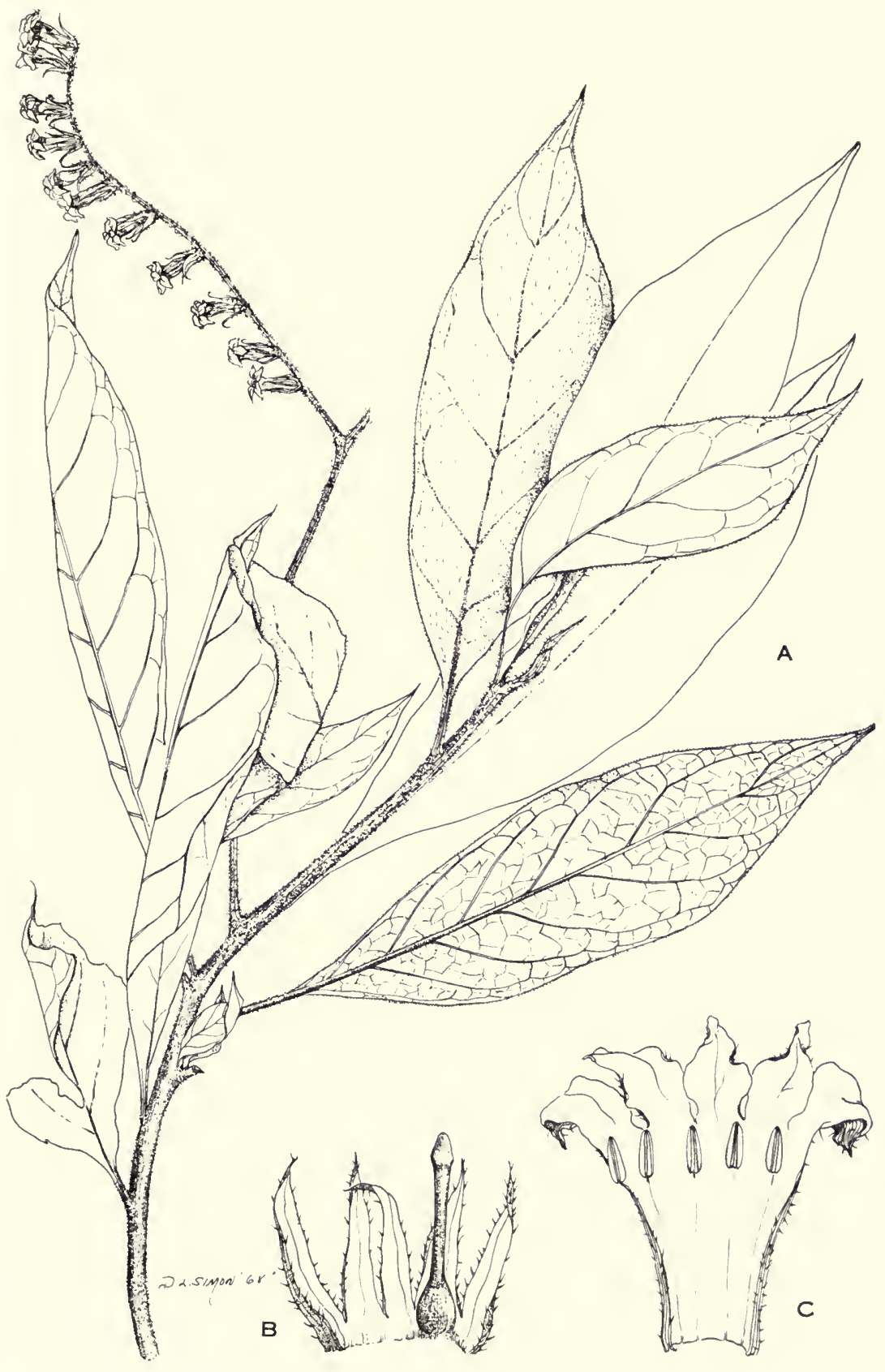

FIG. 30. Tournefortia elongata. A, habit, $1 / 2$ natural size; $B$, calyx opened to show gynoecium, $\times 3 ; \mathrm{C}$, corolla opened to show stamens, $\times 3$. 
blades elliptic-oblong to oblong-ovate, usually $6-25 \mathrm{~cm}$. long, $2-9 \mathrm{~cm}$. wide, long acuminate, long-attenuate to the base, densely hirsute or short-hispid on both surfaces; inflorescences open, lax, of dichotomous helicoid cymes, long pedunculate, the flowers secund; sepals linear to linear-lanceolate, acuminate, 6-9 mm. long, erect, usually densely hispidulous; corolla green or greenish-yellow, the tube hispidulous outside, 8-9 $\mathrm{mm}$. long, the lobes $2.5-3.5 \mathrm{~mm}$. long, triangular, acute, spreading or somewhat recurved; stamens subsessile in corolla throat, anthers ca. $2 \mathrm{~mm}$. long; style elongated, 6-7 $\mathrm{mm}$. long, the entire gynoecium to $9 \mathrm{~mm}$. long, always equalling or exceeding the calyx; fruits white, globose-ovoid, glabrous, ca. $1 \mathrm{~cm}$. in diameter.

Tournefortia elongata closely resembles $T$. johnstonii Standley of Costa Rica. However, the gynoecium of $T$.johnstonii at anthesis is only 5-6 mm. long, the style always shorter than the calyx, the sepals narrowly linear, and the corolla lobes 4-5 $\mathrm{mm}$. long, subulate and acuminate.

The single Mexican specimen seen, Breedlove 9708, is atypical in that the sepals are mostly $3-5 \mathrm{~mm}$. long. However, those of a few flowers are $6 \mathrm{~mm}$. long and occasionally one sepal of a flower will attain $6 \mathrm{~mm}$. while the others remain only $3-4 \mathrm{~mm}$. long.

Tournefortia glabra L. Sp. Pl. 141. 1753. T. cymosa L. Sp. Pl. ed. 2, 202. 1762.

Wet thickets or mixed forest, sometimes along streams, of ten in second growth, 50-2,600 meters; Alta Verapaz; Escuintla; Guatemala; Huehuetenango; Izabal; Petén; Quezaltenango; Retalhuleu; Sacatepéquez; San Marcos; Sololá. Southern Mexico to Panama; South America.

Slender shrubs or small trees to $7 \mathrm{~m}$. tall, the branches glabrous or nearly so; leaves on petioles $1-5 \mathrm{~cm}$. long, the blades lanceolate, oblanceolate, elliptic or ovateelliptic, apex acute or acuminate, acute to long attenuate at base, mostly $7-20 \mathrm{~cm}$. long, usually glabrous or nearly so but when young may be minutely appressedpilosulous, primary lateral veins usually 8-12 pairs; inflorescence usually broad and lax, the dichotomous branches slender, of ten numerous, usually many-flowered, the flowers sessile; calyx usually $1.3-2 \mathrm{~mm}$. long (rarely $3 \mathrm{~mm}$.), the sepals lanceolate or oblong-lanceolate, acute, sparsely and minutely strigillose or almost glabrous; corolla white, greenish white, or yellowish green, the tube minutely puberulent on the outside, dilated near the top, 3-4 mm. long, the lobes 1-2 mm. long, narrowly triangular, acute to acuminate; stamens inserted a little below sinuses, the anthers $0.5-1 \mathrm{~mm}$. long; style elongated, surpassing the sepals at anthesis, and usually reaching a point just below the stamens; fruit subglobose, appearing somewhat turbinate when dry, glabrous, $3-5 \mathrm{~mm}$. in diameter.

Tournefortia gnaphalodes (L.) R. Br. ex Roem. \& Schult. Syst. 4: 538. 1819. Heliotropium gnaphalodes L. Syst. ed. 10: 913. 1759. 
Mallotonia gnaphalodes Britt. Ann. Mo. Bot. Gard. 2: 47.1915. Messerschmidia gnaphalodes I. M. Johnston, Journ. Arn. Arb. 6: 165. 1935.

On open, sandy Atlantic beaches; British Honduras. Southern Florida; Yucatan Peninsula, Mexico; Nicaragua; West Indies.

Stout shrubs to $3 \mathrm{~m}$. tall, of ten forming dense clumps, the branches whitesericeous and densely leafy; leaves linear or linear-spatulate, $4-10 \mathrm{~cm}$. long, obtuse or rounded at apex, attenuate to the base, somewhat succulent, densely whitesericeous; inflorescences equalling or shorter than the leaves, with 2-4 short, densely-flowered bostryces; calyx $3-5 \mathrm{~mm}$. long, the lobes broadly lanceolate, acute, but appearing obtuse due to the densely sericeous indument outside; corolla white, the tube tomentose outside, $4-5 \mathrm{~mm}$. long, the lobes lanceolate, acute, $2-3 \mathrm{~mm}$. long; stamens inserted below the throat of the tube, the anthers ca. $1 \mathrm{~mm}$. long; style shorter than sepals; fruit ovoid, brown, glabrous, $5-6 \mathrm{~mm}$. long, the lower half composed of corky exocarp.

Tournefortia hirsutissima L. Sp. Pl. 140. 1753. Messerschmidtia hirsutissima Roem. \& Schult. Syst. 4: 541. 1819. T. elliptica Mart. \& Gal. Bull. Acad. Brux. 9(2):332. 1844. T. schomburgkii DC. Prodr. 9: 517. 1845. T. alba Splitberger ex DeVriese, Nederl. Kruidkund. Arch. 1: 347. 1848; Schomburgk, Fauna u. Fl. Brit. Guiana 1151. 1848. T. billbergiana Beurl. Vet. Akad. Handl. Stockh. 139. 1856. T. bicolor var. calycosa Donn.-Sm. Bot. Gaz. 14:27. 1889. Nigua (Petén).

Wet or dry thickets or mixed forest, frequently in second growth, sea level to 1,800 meters; Alta Verapaz; Chimaltenango; Chiquimula; Escuintla; Guatemala; Huehuetenango; Izabal; Petén; Retalhuleu; Sacatepéquez; San Marcos. Southern Florida; Mexico; British Honduras to Panama; West Indies; South America.

Suberect shrubs to $3 \mathrm{~m}$. high, or elongating and becoming more or less scandent, the branches hispid or hirsute to nearly glabrous or glabrate; leaves on petioles $0.5-2 \mathrm{~cm}$. long, the blades lance-oblong, oblong-ovate, ovate, or elliptic, mostly 7-20 cm. long, 3-7 cm. broad, usually acuminate, sometimes acute, rarely obtuse, acute or obtuse at the base, usually scabrous-hirsute above or if glabrate, usually rough to the touch, rarely nearly glabrous and smooth; inflorescences of ten large and diffuse, of numerous dichotomous helicoid cymes, the bostryces usually less than $4 \mathrm{~cm}$. long; sepals ovate-lanceolate, lanceolate, oblong, oblanceolate, elliptic, linear, or linear-spatulate, acute or acuminate, hispidulous or nearly glabrous, sometimes papillose, usually $2-4 \mathrm{~mm}$. Iong, rarely $5 \mathrm{~mm}$.; corolla white or greenish, the tube densely or sparsely strigose outside, $4-6 \mathrm{~mm}$. long, the lobes short, obtuse, apiculate; stamens sessile, inserted at or a little below mid-tube, the anthers 1$2 \mathrm{~mm}$. long; style subsessile on ovary; mature fruit globose, white, of ten hispid.

This is a common, weedy plant in many parts of the Central American tierra caliente. Because of the great range of variation in 
quantity of indument on the leaves and stems and the variation in length and form of the sepals, it is difficult to delimit good taxonomic units. The more glabrous forms of $T$. hirsutissima have been confused with the closely related T. bicolor Sw., and Johnston, in his discussion of T. bicolor var. calycosa Donn.-Sm. (Journ. Arn. Arb. 16: 52. 1935) concluded that the differences separating $T$. hirsutissima and T. bicolor "are almost exclusively those of pubescence. . .." Because he felt this difference to be decisive, he retained the var. caly$\cos a$ as a variety of $T$. bicolor; however, the sepals of the true and uniformly glabrous $T$. bicolor are consistently short and ovate to ovate-lanceolate, while those of the var. calycosa are much like many of the various forms of T. hirsutissima. Although Johnston held that the fruits of $T$. bicolor and the var. calycosa are always glabrous, while those of $T$. hirsutissima are usually hairy, a collection from Sacatepéquez in 1935, Skutch 2069, with elongated sepals, glabrous outside and sericeous within, and nearly glabrous leaves, also has many hairy young fruits.

Tournefortia billbergiana Beurl. is also placed here as the leaves are definitely though somewhat sparsely strigose, the fruits are hairy, and the calyx is like those of T. hirsutissima.

In view of the numerous variations and forms which suggest intergradation, until monographic study can be done, it seems best to treat this complex collectively as T. hirsutissima L., sens. lat.

Tournefortia longiloba D. Gibson, Fieldiana: Bot. 32: 68, f. 2.1969 .

On steep, damp slopes, cloud forests, sometimes with Quercus and Pinus, 2,400-3,400 meters; Huehuetenango; El Quiché; El Progreso. Mexico (Chiapas); Costa Rica.

Shrubs to $5 \mathrm{~m}$. tall; leaves on stout, tomentose petioles $1-3.5 \mathrm{~cm}$. long, the blades lance-oblong or lance-elliptic, mostly $8-18 \mathrm{~cm}$. long, $3-5 \mathrm{~cm}$. wide, acute to acuminate, usually attenuate to the base, rarely rounded to obtuse and abruptly decurrent, usually puberulous above, tomentose to velutinous below (rarely gla. brate), with 8-14 pairs of lateral nerves; inflorescences paniculate, of few to many dichotomous cymes, the bostryces many-flowered, the flowers secund, of ten placed at intervals of 5-6 mm., sessile or on pedicels 1-6 mm. long; sepals ovate-lanceolate to lanceolate, acute, hispidulous to hirsutulous, 3-5 mm. long; corolla white, the tube hirsutulous on the outside, ca. $5 \mathrm{~mm}$. long, the lobes narrowly triangular, acuminate, spreading to recurved, $3-4.5 \mathrm{~mm}$. long; stamens included, sessile or subsessile, inserted in tube at a point just above the middle and ca. $3 \mathrm{~mm}$. above the base, anthers 1.5-2 $\mathrm{mm}$. long; ovary subglobose, the style short, not exceeding the sepals at anthesis; mature fruits globose-ovoid, white, 7-9 mm. long, 5-6 mm. in diameter when dry. 
Sometimes confused with T. acutiflora Mart. \& Gal. which it superficially resembles. However, the style of T. acutiflora is elongated, considerably surpassing the sepals; the corolla lobes are only $2.5-3 \mathrm{~mm}$. long, and the corolla tube is $6-7 \mathrm{~mm}$. long. T. longiloba is probably closely related to T. subspicata Donn.-Sm. of Costa Rica, which also has a short style and long corolla lobes, but has a nearly glabrous calyx, a longer corolla tube $(7 \mathrm{~mm}$. long) with appressed hairs, and leaves that are glabrous beneath or very sparsely pubescent.

Tournefortia maculata Jacq. Enum. Pl. Carib. 14. 1760. T. syringaefolia Vahl, Symb. Bot. 3: 23. 1794. T. peruviana Poir. Encycl. Suppl. 4: 425. 1816. T. sagraena DC. Prodr. 9: 522. 1845. T. guadelupensis Urban in Fedde, Rep. Sp. Nov. 17: 169. 1921. Messerschmidtia syringaefolia (Vahl) Roem. \& Schult. Syst. 4: 543. 1819.

Damp thickets or mixed forest, 800-1,500 meters; Alta Verapaz; Petén; Quezaltenango; San Marcos; Sololá. Honduras to Panama; West Indies; tropical South America.

Woody vines, the branches slender, sparsely or densely short-hirtellous or almost glabrous; leaves on petioles $0.5-1.5 \mathrm{~cm}$. long, the blades ovate to lance-elliptic or broadly lanceolate, mostly $3-10 \mathrm{~cm}$. long, $1-5 \mathrm{~cm}$. wide, acute to acuminate, rounded to acute at the base, usually almost glabrous; inflorescences lax, of slender dichotomous cymes with bostryces to $5 \mathrm{~cm}$. long; flowers sessile or very short-pedicellate, $2-8 \mathrm{~mm}$. apart; calyx $0.5-1.5(2) \mathrm{mm}$. long, the sepals usually ovate-lanceolate, somewhat strigillose; corolla pale green to greenish white, the tube narrowly cylindric, strigillose outside, $3-4(5) \mathrm{mm}$. long, the lobes $1.5-2 \mathrm{~mm}$. long, acuminate, spreading; stamens inserted in throat of tube, subsessile, the anthers usually connate at their apices; style elongated, filiform, the gynoecium as long as the corolla tube; fruit yellow or orange, glabrous, conspicuously 4 -lobate, containing 4 oneseeded nutlets.

A single specimen from Alta Verapaz, von Turckheim 1790, is atypical; monographic study may prove it to be a form, or it may represent a species new to Central America. The stems and petioles are densely invested with erect to shaggy hairs, the sepals are acuminate, ca. $2 \mathrm{~mm}$. long and pilose; the costae and margins of young leaves are pilose; the mature leaf blades are thick and glabrate. The plant is much like the South American T. elegans Cham., which Johnston considered synonymous with $T$. paniculata Cham. For a discussion of $T$. paniculata and its relation to $T$. maculata (as $T$. syringaefolia Vahl and as T. peruviana Poir.) see Johnston, Contr. Gray Herb. 92: 78. 1930 and Journ. Arn. Arb. 16: 49. 1935.

There is also a plant in Honduras, A. Molina 7269, which closely resembles those from the West Indies, described as T. laurifolia Vent. 
It has longer sepals and corolla lobes and the corolla tube is glabrous save for some puberulence below the lobes. (See Johnston, Journ. Arn. Arb. 30: 130-131. 1949.)

The vesture of plants from southern Central America is often much heavier than that of ours.

Tournefortia petiolaris DC. Prodr. 9: 520. 1845. T. nelsonii Donn.-Sm., Bot. Gaz. 23: 10. 1897.

Damp or dry slopes, ravines, wet cloud forest, 1,400-3,000 meters; Chimaltenango; Chiquimula; Jalapa; El Quiché; Sacatepéquez; San Marcos; Sololá; Zacapa. Southern Mexico; El Salvador.

Shrubs or weak trees to $8 \mathrm{~m}$. tall, the stems and branches tomentose or strigillose or nearly glabrous; leaves on petioles usually 2-3 (rarely to 10 ) $\mathrm{cm}$. long, the blades elliptic, ovate elliptic, oblong-ovate, oblanceolate, or lance-ovate, mostly $8-15 \mathrm{~cm}$. long (rarely to $25 \mathrm{~cm}$.), 3-12 cm. wide, acute or acuminate, of ten attenuate to the base but may be obtuse or almost rounded or abruptly contracted and decurrent, somewhat scabrid to velutinous or nearly glabrous above, of ten glabrous or with only short puberulence beneath but may be velutinous; inflorescences usually large, long pedunculate, repeatedly dichotomous, the bostryces slender, usually lax, many flowered, the flowers often $2-4 \mathrm{~mm}$. apart, mostly sessile or subsessile but occasionally with some flowers on pedicels 1-2 mm. long; calyx segments lanceolate or oblong-lanceolate, acute to acuminate, $2-3.5 \mathrm{~mm}$. long, usually hispidulous; corolla greenish white or yellowish green, the tube $5-6 \mathrm{~mm}$. long, hispidulous outside, the lobes ovate to lanceolate, acute, 1-2 mm. long; stamens with short filaments inserted below the throat, anthers 1-1.5 mm. long; style at anthesis surpassing the calyx and elongating in maturity; fruit greenish white, globose obovoid when dry, glabrous.

Apparently closely related to T. acutiflora Mart. \& Gal., which has longer, acuminate corolla lobes.

The very large leaf form, in which the blade is abruptly contracted and decurrent has also been observed on specimens of $T$. acutiflora and T. longiloba D. Gibson. The plants of T. petiolaris with large leaves usually have longer petioles. Donnell-Smith, a year after proposing his new species, $T$. nelsonii, based on this large and velutinous leaf form, rejected it, stating that "it does not appear to differ from T. petiolaris DC."

Tournefortia volubilis L. Sp. Pl. 140. 1753. T. sericea Vahl, Ecol. 1: 17. 1796. T. floribunda HBK. Nova Gen. \& Sp. 3: 79.1818. T. velutina HBK. l.c. t. 201. 1819. T. potosina Standl. Contr. U. S. Nat. Herb. 23: 1230. 1924. Miona (Zacapa).

Damp or dry thickets, brushy, rocky slopes, sometimes in hedges or clearings, 120-1,000 meters; Baja Verapaz; Guatemala; Jalapa; 
Jutiapa; El Progreso; El Quiché; Zacapa. Southern Florida and Texas; Mexico; El Salvador; Honduras; Nicaragua; West Indies; northern South America.

Woody vines, often diffusely branching, the branches slender, usually densely white tomentose; leaves on petioles $2-10 \mathrm{~mm}$. long, ovate to oblong, lance-oblong or (rarely) linear-lanceolate, the blades $2-8 \mathrm{~cm}$. long, $0.6-3.5 \mathrm{~cm}$. wide, acute or acuminate, usually rounded or obtuse at the base, usually densely tomentose beneath with soft grey or white hairs, of ten equally tomentose above or sometimes glabrate; inflorescences slender-pedunculate, usually small, of few-many slender, forking cymes to $4 \mathrm{~cm}$. long with flowers 2-6 $\mathrm{mm}$. apart; sepals 1-2 mm. long, linear-lanceolate, acute or acuminate; corolla greenish-white, the tube $1.5-2.5 \mathrm{~mm}$. long, densely sericeous outside, the lobes linear-subulate, a little shorter than the tube; style at anthesis about equalling the calyx; stamens inserted in throat of tube, the small anthers of ten connate at their apices; fruits depressed, white with black dots, conspicuously 4-lobate, glabrous, 2-3 mm. long.

The fruits are often modified into insect galls and are then much larger than normal and densely white-pilose.

\title{
VERBENACEAE. Verbena family
}

\author{
DoROThY N. GiBson
}

Reference: H. N: Moldenke, Verbenaceae (of the Maya area), Carnegie Inst. Wash. Publ. 522: 148-223. 1940.

Mostly trees or shrubs, sometimes herbs or woody vines; branches often tetragonous; leaves mostly opposite, without stipules, simple or palmately compound, the blades entire or variously dentate, lobate, cleft, or incised; inflorescences axillary or terminal, cymose, paniculate, racemose, or spicate, sometimes capitate, the flowers perfect or imperfect, small or large; calyx gamopetalous, persistent and of ten accrescent, usually with 4-5 lobes or teeth; corolla gamopetalous, regular or irregular, funnelform or salverform, the lobes 4 or 5 , the limb often somewhat bilabiate; stamens usually 4 and didynamous, rarely 2 , the filaments inserted on the corolla tube, staminodes sometimes present; ovary of 2 , rarely $4-5$ carpels, of ten with 4 lobes, usually with $2-5$ locules, rarely unilocular, the locules with 1 or 2 ovules; ovules anatropous and basal or sometimes lateral on a central or axile placenta; fruit a dry schizocarp or drupaceous, usually with 2-4 locules (rarely 1), indehiscent or separating into 2 or 4 cocci or pyrenes.

About 75 genera, in both hemispheres, chiefly in tropical regions. Only the following are native in Central America. One other, a native of southern Asia, Holmskioldia sanguinea Retz., is sometimes cultivated in Guatemala for ornament. It is a pubescent or glabrate shrub with ovate, entire or dentate leaves conspicuously punctate beneath; the flowers are in dense terminal racemes; the calyx is rotate, bright red or orange, orbicular, $2.5 \mathrm{~cm}$. broad, entire; corolla 
is brick-red or orange, $2-2.5 \mathrm{~cm}$. long. In Costa Rica this plant is called "sombrero chino."

Leaves palmately compound ......................... Vitex.

Leaves simple.

Inflorescence cymose or paniculate.

Fertile stamens 2; staminodes $2 \ldots \ldots \ldots \ldots \ldots \ldots \ldots \ldots$. Cornutia.

Fertile stamens 4 or 5 .

Indument of stellate or dendroid hairs; stigma capitate or peltate.

Indument of simple hairs; stigma bifid.

Callicarpa.

Stigma deeply bifid, the lobes subulate................ Aegiphila.

Stigma shallowly bifid, the lobes acute..............Clerodendrum. Inflorescence spicate or racemose.

Fertile stamens 2; staminodes 2; calyx closely appressed to rachis and often more or less immersed in it.................... Stachytarpheta.

Fertile stamens 4 ; staminodes 1 or none; calyx not appressed to rachis.

Fruits capsular; ovary unilocular..................... Avicennia.

Fruits not capsular; ovary bilocular or with 4 perfect or imperfect locules.

Calyx deeply lobate, the lobes showy, elongating and much enlarged in fruit, usually blue or purple, rarely white, reticulate veined. . Petrea.

Calyx not as above.

Plants herbaceous or sometimes woody at base.

Fruiting calyx globose, bearing minute, uncinate hairs.......Priva. Fruiting calyx not globose, without uncinate hairs.

Corolla with 4 lobes; calyx minute and inconspicuous.... Lippia.

Corolla with 5 lobes; calyx evident, not minute.

Fruiting calyx broadly campanulate; fruit with slightly fleshy exocarp . .......................... Tamonea.

Fruiting calyx tubular; fruit dry.

Style filiform; fruit composed of 2 rostrate cocci.... Bouchea. Style short; fruit composed of 4 cocci, not rostrate. .Verbena.

Plants trees or shrubs.

Fruit dry.

Corolla with 5 lobes; calyx early deciduous; ovary with 4 locules; fruit $8-20 \mathrm{~mm}$. long, naked............... Rehdera.

Corolla with 4 lobes; calyx persistent, enclosing fruit; ovary with 2 locules; fruit less than $4 \mathrm{~mm}$. long.............. Lippia. Fruit drupaceous.

Fruiting calyx contracted at the apex and completely enclosing the fruit. ........................ Duranta.

Fruiting calyx not contracted nor completely enclosing the fruit.

Inflorescence headlike, the flowers in dense, usually short spikes; calyx small and inconspicuous; ovary bilocular..Lantana.

Inflorescence not headlike, the flowers in elongated, of ten lax racemes; calyx evident; ovary with 4 perfect or imperfect locules............................ Citharexylum.

\section{AEGIPHILA Jacquin}

Reference: Harold N. Moldenke, A monograph of the genus Aegiphila, Brittonia 1: 245-477. 1934. 
Shrubs or small trees, sometimes scandent, the branches tetragonal or subterete; leaves simple, usually opposite and decussate, rarely verticillate, deciduous, estipulate; inflorescences cymose, the cymes often appearing paniculate or simulating corymbs or heads, axillary or terminal; calyx more or less campanulate or tubular, the margin truncate and entire or subtruncate and scarious or with $4-5$ teeth or lobes, accrescent and thickened in fruit; corolla funnelform or salverform, the tube cylindric, the limb 4-5-parted, the lobes imbricate; stamens 4-5, equal or subequal, inserted below the mouth of the tube, included or exserted; style terminal, the stigma bifid, the branches subulate; ovary perfectly or imperfectly 4-locular, each locule uniovulate, the ovules attached laterally; fruits drupaceous, usually 4-seeded, or the seeds by abortion fewer, without endosperm.

Heterostyly is present in most (perhaps all) species; floral characters within the genus are usually not especially significant; there is considerable clinal variation in leaf form and size, and sometimes in size of inflorescences. It is therefore, regrettably, often difficult to separate species morphologically, especially those with large, paniculiform inflorescences, without relying heavily on differences in the fruiting calyces.

Perhaps 150 species in tropical America. Only ten are known from Guatemala, but 12 are treated here. Aegiphila deppeana Steud. and $A$. valerii Standley occur in Chiapas, Mexico as well as in southern Central America and are therefore included here. One plant previously reported from Guatemala has been omitted, as $A$. hoffmannioides Standley \& Steyermark has an inferior ovary and is actually Hoffmannia lenticellata Hemsl. (Rubiaceae).

Inflorescences appearing paniculate or corymbiform, usually appearing terminal.

Margins of fruiting calyces always entire, truncate or subtruncate.

A. laxicupulis.

Margins of fruiting calyces lobate or irregularly torn, often somewhat scarious.

Fruiting calyces shallowly cupuliform to patelliform, the margins always dis-

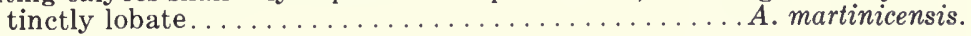

Fruiting calyces first urceolate, later deeply cupuliform, the margins irregularly torn.

Internodes usually 1-2 cm. long; calyces at anthesis truncate or subtruncate (rarely irregularly lobate); fruiting calyces ca. $3 \mathrm{~mm}$. long.

A. skutchii.

Internodes usually $3-8 \mathrm{~cm}$. long; calyces at anthesis lobate; fruiting calyces 4-7 mm. long.

Pedicels and calyces minutely appressed-puberulent; leaves essentially glabrous beneath with $7-12$ pairs of lateral veins........ A. elata.

Pedicels and calyces shortly and densely tomentose; leaves densely or sparsely tomentose beneath with 5-8 pairs of lateral veins.

A. deppeana.

Inflorescences cymose, axillary or lateral.

Inflorescences pedunculate.

Peduncles often half as long as the leaves, lax

A. costaricensis.

Peduncles very short, only $4-15 \mathrm{~mm}$. long, not lax. 
Leaves very large, $25-45 \mathrm{~cm}$. long, to $16 \mathrm{~cm}$. wide, with $20-22$ pairs of

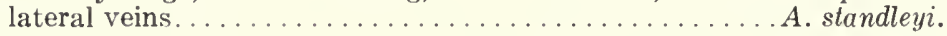

Leaves $3-20 \mathrm{~cm}$. long, $2.5-7.5 \mathrm{~cm}$. wide, with 7-16 pairs of lateral veins. Corollas 5-parted; leaves with $10-16$ pairs of lateral veins....A. valerii. Corollas 4-parted; leaves with 7-9 pairs of lateral veins.

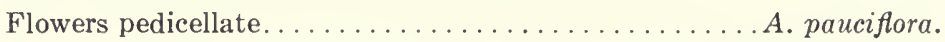

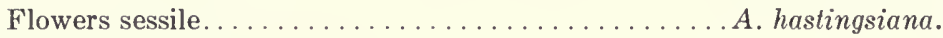
Inflorescences sessile and fasciculate.

Calyces 2-3.5 mm. long, minutely pubescent or almost glabrous.

A. monstrosa.

Calyces 6-8 mm. long, densely ochraceous-velutinous. A. fasciculata.

Aegiphila costaricensis Moldenke in Fedde, Rep. Sp. Nov. 33: 119. 1933. Clerodendron matudae Standl. Field Mus. Bot. 17: 206. 1937.

Mixed lowland forest, 720 meters; Quezaltenango (near Colombia, Skutch 2012). Mexico (Chiapas); Costa Rica; Panama.

Trees to $8 \mathrm{~m}$. tall, the branchlets glabrous or sparsely pilose at the nodes, the trunk as much as $20 \mathrm{~cm}$. in diameter, the crown broad and flat, the bark pale brown, slightly roughened; leaves opposite or ternate, often somewhat crowded near the ends of the branches, on petioles $3-7 \mathrm{~mm}$. long, the blades membranaceous, lance-oblong to oblanceolate or obovate, 7-30 cm. long, 4-10 cm. wide, acute or acuminate, cuneate-acute at the base, glabrous, entire, the leaves of a pair often very unequal; cymes axillary on long, slender peduncles, of ten half as long as the leaves, very lax, few-flowered, the pedicels 1-3 cm. long, filiform, glabrous; calyx broadly campanulate, $2-5 \mathrm{~mm}$. long, glabrate, subtruncate, usually 4-cuspidate; corolla white, the tube 4-8 $\mathrm{mm}$. long, glabrous, the 5 lobes $6-8 \mathrm{~mm}$. long; stamens 5, usually long-exserted; fruit ovoid, first yellow, at maturity black, $5 \mathrm{~mm}$. long or larger.

Readily distinguished from other local species by the 5-parted rather than 4-parted corollas, and by the lax inflorescence with greatly elongated pedicels and slender peduncles.

Aegiphila deppeana Steud. Nom. Bot. ed. 2, 1:29.1840. A. brachiata Cham. \& Schlecht. Linnaea 6: 371. 1831 (not A. brachiata Vell. 1825). A. berteriana Schauer in DC. Prodr. 11: 654. 1847. A. pacifica Greenm. Proc. Am. Acad. 33: 485. 1898.

Petén; at or near sea level. Southern Mexico; Nicaragua; Costa Rica.

Shrubs or small trees, often subscandent, to $7 \mathrm{~m}$. tall; branchlets obtusely tetragonal or terete, shortly and densely tomentose, sometimes glabrate in age; leaves on petioles 4-13 $\mathrm{mm}$. long, these densely tomentose, the blades membranous to subcoriaceous, ovate to oblong-ovate, $5-16 \mathrm{~cm}$. long, 2-9 cm. wide, entire, acute to short-acuminate, rounded or acute at base, indument of upper surface confined 
to midrib and to the 4-8 pairs of lateral veins, usually densely tomentose beneath, rarely glabrate in age; inflorescences cymose, appearing paniculate, the cymes in the axils of the upper leaves, about half as long as the leaves, bracteate, manyflowered, peduncles and pedicels tomentose, the pedicels ca. $3 \mathrm{~mm}$. long; calyx campanulate at anthesis, 3-4 mm. long, 4-lobate, pubescent to tomentose, in fruit cupuliform, 6-9 mm. long, indurated, somewhat tomentose to glabrate, rugose, irregularly and shallowly lobed; corolla white to pale yellow, glabrous, the tube 5-6 mm. long, the 4 lobes $3-4 \mathrm{~mm}$. long; fruits obovoid, yellow, to $10 \mathrm{~mm}$. long.

\section{Aegiphila elata Swartz, Prodr. Veg. Ind. Occ. 31. 1788.}

Damp thickets, brushy slopes, often in second growth, 75-350 meters; Alta Verapaz; Izabal; Petén (fide Moldenke). Southern Mexico; British Honduras to Panama; West Indies; South America.

Erect shrubs or woody vines, the branchlets glabrous or minutely puberulous, sometimes compressed and widened at the nodes; leaves on petioles 5-15 mm. long, the blades ovate, oblong-ovate, or elliptic, $6-15 \mathrm{~cm}$. long, $2-7 \mathrm{~cm}$. wide, acute to acuminate, obtuse or rounded at the base, entire, sometimes somewhat asymmetric, glabrous above and of ten lustrous, glabrous beneath or appressed-pubescent only on the costae and veins, minutely glandular-punctate beneath, lateral veins $7-12$ pairs; inflorescences of ten large, the cymes many-flowered, dense or rather open, the pedicels $4-8 \mathrm{~mm}$. long, puberulent; calyx at anthesis more or less puberulent, turbinate-funnelform, 3-5 $\mathrm{mm}$. long, the margin usually with 4 distinct lobes but may be subtruncate, in fruit first flask-shaped, later cupuliform, 4-7 mm. long, the margin irregularly lobate, of ten becoming somewhat scarious; corolla cream-colored to pale yellow, the tube 5-8 $\mathrm{mm}$. long, ca. $1 \mathrm{~mm}$. broad, glabrous, the 4 lobes 3 $6 \mathrm{~mm}$. long; filaments of stamens inserted about midway of the tube; fruit subglobose to oblong-ovoid, yellow to orange, ca. $7 \mathrm{~mm}$. long, $5-6 \mathrm{~mm}$. broad.

Aegiphila fasciculata Donn.-Sm. Bot. Gaz. 57: 425. 1914.

Known only from the type, collected near Cobán, Alta Verapaz, 1,350 meters, Tuerckheim 4013, and a single collection from Nicaragua, 1,400 meters, L. O. Williams et al. $2775 \%$.

Trees to $6 \mathrm{~m}$. tall, the branches stout, densely ochraceous-velutinous; leaves on petioles $2-3.5 \mathrm{~cm}$. long, the blades coriaceous, lance-oblong to ovate-elliptic, 12-22 cm. long, 5-8 cm. wide, acuminate, acute at the base, entire, sparsely or densely spreading-pilose above, ochraceous-tomentose beneath, the lateral nerves 7-9 pairs; inflorescences axillary, sessile, the cymes fasciculate, subglomerate, densely flowered, the pedicels 1-2 mm. long; calyx turbinate-campanulate, $6-8 \mathrm{~mm}$. long, 4-mucronulate, densely ochraceous-velutinous; corolla white, the tube 5$6 \mathrm{~mm}$. long, glabrous, the 4 lobes $4-5 \mathrm{~mm}$. long; ovary glabrous; fruit unknown.

Aegiphila hastingsiana Moldenke, Phytologia 1:207. 1937.

Known only from the type, said to have been collected in Guatemala in 1864 by R. Grosourdy. 
Branchlets slender, obtusely tetragonal, densely short-pulescent; leaves chartaceous, on petioles $3-10 \mathrm{~mm}$. long, the blades elliptic to ovate-elliptic, $3-10 \mathrm{~cm}$. long, 2.5-4.5 cm. wide, short-acuminate, rather long-acuminate at the base, entire, puberulent to short-pubescent above, densely velutinous-pubescent beneath, densely punctate, the lateral nerves 7-9 pairs; inflorescences pedunculate, the peduncles $5-10 \mathrm{~mm}$. long, axillary, the cymes solitary, $1.5-2.5 \mathrm{~cm}$. long, densely flowered, the flowers sessile; calyx campanulate, $3 \mathrm{~mm}$. long, densely short-pubescent, the 4 lobes ovate, acute; corolla tube about $2.5 \mathrm{~mm}$. long, glabrous, the 4 lobes $2 \mathrm{~mm}$. long; ovary glabrous.

Aegiphila laxicupulis Moldenke in Fedde, Rep. Sp. Nov. 33: 130. 1933 (type, Heyde 191, perhaps from Santa Rosa). A. magnifica Moldenke, l.c. 132 (type from Nicaragua).

Damp thickets and second growth woods, 330-1,050 meters; Chiquimula; Escuintla; Quezaltenango; Santa Rosa; Suchitepéquez. Honduras; Nicaragua; Costa Rica.

Large, of ten subscandent shrubs or small trees to $9 \mathrm{~m}$. tall; branchlets slender, obtusely tetragonal or subterete, of ten compressed and somewhat widened at the the nodes, glabrous or puberulent; leaves on petioles $5-10 \mathrm{~mm}$. long, the blades membranaceous, lanceolate, ovate-oblong or oblong, 6-20 cm. long, acuminate, rounded or acute at the base, very minutely puberulent to glabrate above and below, minutely glandular-punctate beneath, the lateral veins 9-12 pairs; inflorescences cymose, appearing paniculate, small or large, usually $9-20 \mathrm{~cm}$. long, the cymes many-flowered, the pedicels $2-3 \mathrm{~mm}$. long at anthesis; calyx obpyramidal at anthesis, $2-3 \mathrm{~mm}$. long, truncate or subtruncate, usually minutely puberulous, in fruit cupuliform, indurated, the margin truncate or subtruncate, $3-6 \mathrm{~mm}$. long, 7-10 mm. broad; corolla cream-colored; mature fruits subglobose to barrelshaped, orange, glabrous, to $1 \mathrm{~cm}$. long.

Although the type specimen of $A$. magnifica has larger leaves than some specimens of A. laxicupulis, Moldenke's two species differ in no other respect if one may judge from specimens determined by him. Whether or not the calyx closely invests the fruit seems to depend upon the stage of growth and development of the plant. A. laxicupulis has also been confused by Moldenke and others with $A$. paniculata Moldenke, a tree of the lowlands of southern Central America and South America, which differs in its patelliform fruiting calyces that are only $2-2.5 \mathrm{~mm}$. long. As I am unable to separate flowering material of any of these taxa from that of A. martinicensis Jacq., perhaps they should all be placed there; however, the fruiting calyces of A.martinicensis are lobate.

Aegiphila martinicensis Jacq. Obs. Bot. 2: 3, t. 27. 1767. A. panamensis Moldenke, Trop. Woods 25: 14. 1931. A. glandulifera Moldenke, Brittonia 1: 187. 1932. Chiploque (Retalhuleu). 


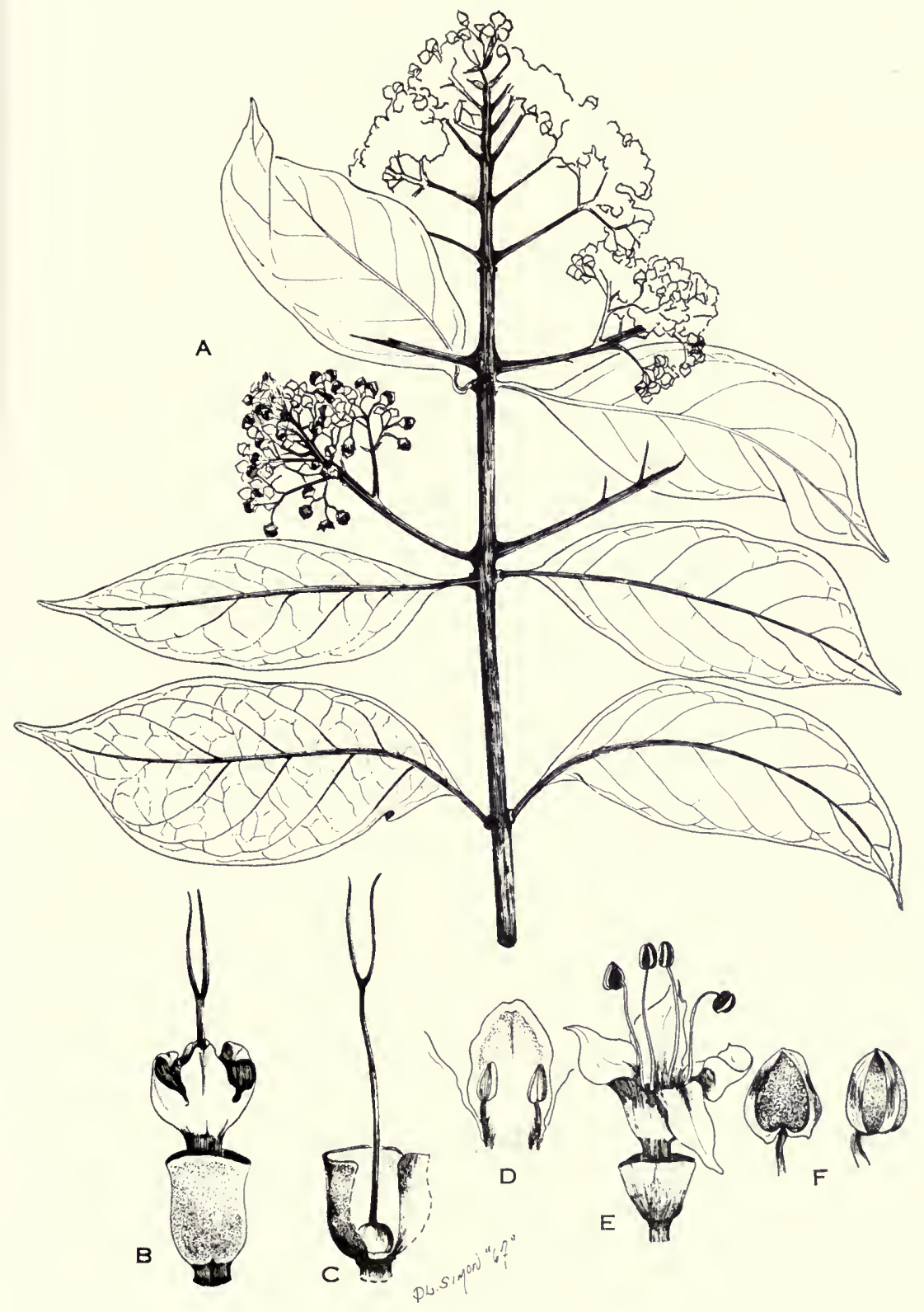

FIG. 31. Aegiphila laxicupulis. A, habit, 1/2 natural size; B, long-styled flower, $\times 3$; C, calyx of long-styled flower opened to show pistil, $\times 3$; D, stamens of short-styled flower, $\times 5 ; \mathrm{E}$, short-styled flower, $\times 3 ; \mathrm{F}$, detail of stamens, $\times 10$. 
Damp or dry thickets or lowland forest, often in second growth, 30-1,060 meters; Escuintla; Quezaltenango; Retalhuleu; Suchitepéquez; Santa Rosa. Southern Mexico; El Salvador to Panama; West Indies; South America.

Shrubs or trees, sometimes $15 \mathrm{~m}$. tall, sometimes more or less scandent, the branchlets compressed and often widened at the nodes, glabrous or puberulent; leaves on petioles $6-25 \mathrm{~mm}$. long, the blades lanceolate, lance-ovate, lanceoblong, or ovate-oblong, 6-20 cm. long, 3-8 cm. wide, long acuminate or abruptly acuminate, rounded to acute at the base, entire, sometimes somewhat asymmetric, glabrous or very minutely puberulent, minutely glandular-punctate beneath, the lateral nerves 8-16 pairs; inflorescences often large, cymose-paniculate, pedicels $2-5 \mathrm{~mm}$. long, the flowers very numerous; calyx obpyramidal at anthesis, $2-3.5 \mathrm{~mm}$. long, truncate or minutely apiculate or irregularly lobed, in fruit of ten much enlarged, 2-5 mm. long, 6-10 mm. wide, shallowly cupuliform or patelliform, shallowly or deeply lobed, rarely merely repand; corolla white, creamcolored, pale greenish-yellow or reddish-yellow, the tube $2-6 \mathrm{~mm}$. long, 1-2 $\mathrm{mm}$. wide, minutely puberulous, the 4 lobes oblong lanceolate, $2-4 \mathrm{~mm}$. long; fruit 7-10 mm. long, 6-8 mm. broad, glabrous, orange, with 4 seeds.

The two species described by Moldenke, although far separated in his key, differ in no respect from $A$. martinicensis or from each other if one may judge from specimens determined by him.

A. martinicensis f. falcata (Donn.-Sm.) D. Gibson, Fieldiana: Bot. 32. (11): 176. 1970. A. falcata Donn.-Sm. Bot. Gaz. 18: 7. 1893.

Differs from $A$. martinicensis only by its larger leaves, $14-30 \mathrm{~cm}$. long, 6-14 cm. wide, and in its often more conspicuously thickened and flattened nodes of the branchlets.

Aegiphila monstrosa Moldenke, Trop. Woods 25: 12. 1931. Hulub (British Honduras).

Wet thickets or thin forest, often in second growth, 300 meters or less; Alta Verapaz; Izabal; Petén. Mexico (Oaxaca); British Honduras; Atlantic lowlands of Honduras.

Shrubs or trees, sometimes $9 \mathrm{~m}$. tall but usually lower, the trunk of ten branched from the base, the branches very soft and brittle, the younger ones very thick, whitish or ochraceous, obtusely tetragonal, glabrous or minutely puberulent; leaves on petioles $2-7.5 \mathrm{~cm}$. long, the blades membranaceous, oblong to elliptic or ellipticobovate, $12-35 \mathrm{~cm}$. long, 7-23 cm. wide, acute or subacuminate, acute or attenuate to the base, minutely puberulent or in age glabrate, the lateral veins about 10 pairs; inflorescences sessile, cymose, the cymes numerous, usually at defoliated nodes, very dense and glomerate, many. flowered, the flowers fragrant, on pedicels 1-2 mm. long; calyx campanulate, $2-3.5 \mathrm{~mm}$. long and broad at anthesis, minutely pubescent or almost glabrous, subtruncate, in fruit cupuliform, much enlarged and indurated, verrucose; corolla white, the tube $8-10 \mathrm{~mm}$. long, glabrous or minutely 
puberulent, the 4 lobes 3-4 mm. long; fruit subglobose or ovoid, 7-10 mm. long and broad, glabrous.

\section{Aegiphila pauciflora Standley, Trop. Woods 16: 41.1928.}

Known only from the type, Indian guamil camp VI, Vaca, Western Cayo District, British Honduras, Duncan Stevenson 5.

A tree, the branchlets obtusely tetragonal, puberulent or strigillose; leaves chartaceous, on petioles $1.5-2 \mathrm{~cm}$. long, the blades oblong-elliptic, 7-10 cm. long, 3-4 cm. wide, acuminate, cuneate at the base, entire, grayish-strigillose when young, becoming glabrate, the lateral veins $7-8$ pairs; cymes solitary, axillary, lax, few-flowered, the peduncles 6-15 mm. long, the slender pedicels $1.5-3 \mathrm{~mm}$. long, strigillose; calyx broadly turbinate, $2.5-3 \mathrm{~mm}$. long, grayish-strigillose, truncate; corolla glabrous, the tube $3-4 \mathrm{~mm}$. long, the lobes $2.5 \mathrm{~mm}$. long; ovary glabrous; fruits unknown.

\section{Aegiphila skutchii Moldenke, Phytologia 1: 399. 1940.}

Type collected at Finca Mocá, Suchitepéquez, in forest, 1,400 meters, A.F. Skutch 155. Mexico (Chiapas).

Trees to $15 \mathrm{~m}$. tall, the trunk $50 \mathrm{~cm}$. in diameter, the branchlets minutely puberulent, the nodes 1-2 cm. apart; leaves on petioles 1-3 cm. long, the blades membranaceous, elliptic-oblong, $8-15 \mathrm{~cm}$. long, $1.5-5 \mathrm{~cm}$. wide, acuminate, acute at the base, entire, minutely puberulent, especially on the midrib and near the base, or almost glabrous, the lateral veins 7-9 pairs; inflorescence $5-10 \mathrm{~cm}$. long, the cymes $4-9 \mathrm{~cm}$. long, many-flowered, the peduncles $2-5 \mathrm{~cm}$. long, the pedicels 1-2 mm. long, minutely puberulent; calyx at anthesis campanulate, truncate, 2$3 \mathrm{~mm}$. long, cinereous-puberulent, in fruit first urceolate, later cupuliform, irregularly torn, ca. $3 \mathrm{~mm}$. long; corolla white, the tube $3 \mathrm{~mm}$. long, the lobes $3 \mathrm{~mm}$. long; fruits apparently subglobose (only immature fruits seen).

Aegiphila standleyi Moldenke, in Fedde, Rep. Sp. Nov. 33: 140. 1933.

Damp forest, 1,000-1,250 meters; Sacatepéquez (Barranco Hondo, Standley 65004). Costa Rica.

Large shrubs to $3 \mathrm{~m}$. tall, the branchlets thick, glabrate; leaves on stout petioles 1-2 cm. long, the blades obovate, thick, membranaceous, very large, as much as $45 \mathrm{~cm}$. long and $16 \mathrm{~cm}$. wide, acute or short-acuminate, attenuate to the base, finely and sparsely puberulent or glabrate, the margin somewhat repand-dentate or entire, lateral veins about 20 pairs; inflorescences cymose, axillary, densely flowered, the peduncles $6-10 \mathrm{~mm}$. long, the pedicels ca. $3 \mathrm{~mm}$. long; calyx at anthesis cupuliform, $3.5-4 \mathrm{~mm}$. long, minutely puberulent, subtruncate, immature fruiting calyx cupuliform to campanulate, $4 \mathrm{~mm}$. long, verrucose; corolla not seen, said to be glabrous, the tube said to be $1.5 \mathrm{~mm}$. long and the 4 lobes $2 \mathrm{~mm}$. long; no mature fruits seen.

It should be noted that this record for Guatemala is based on a sterile specimen annotated by Moldenke. 
Aegiphila valerii Standl. Journ. Wash. Acad. Sci. 15: 481. 1925.

Not reported from Guatemala, but as it occurs in Chiapas, Mexico (1,200 meters) as well as in Costa Rica (750-850 meters), it may be expected in Guatemala.

Trees to $20 \mathrm{~m}$. tall, the branchlets stout, covered with pale tomentum of short, appressed hairs; leaves on petioles 1-2 $\mathrm{cm}$. long, the blades obovate, mostly 7$20 \mathrm{~cm}$. long and $4-7.5 \mathrm{~cm}$. wide, acute or short-acuminate, cuneate at the base, entire, sparsely and minutely puberulent or glabrate, of ten more densely puberulent on lower surface, lateral veins 10-16 pairs; inflorescences of short, axillary, cymes, usually densely flowered, peduncles $4-10 \mathrm{~mm}$. long, pedicals $1-3 \mathrm{~mm}$. long, both minutely appressed tomentose; calyx $3-5 \mathrm{~mm}$. long, obconic, truncate, appressed tomentulose; corolla glabrous, the tube $3-5 \mathrm{~mm}$. long, the 5 lobes ca. $3 \mathrm{~mm}$. long; fruits globose.

Often misidentified in herbaria as $A$. anomala Pittier, which has flowers that are twice as large as those of $A$. valerii.

\section{AVICENNIA L.}

Trees or large shrubs of seashores, the branches nodose; leaves opposite, shortpetiolate, without stipules, the blades coriaceous, entire; inflorescences more or less spicate, arising in the axils of the upper leaves, of ten forming pedunculate panicles; flowers bracteate, small; calyx spreading, persistent, its 5 lobes imbricate, divided nearly to the base; corolla broadly campanulate, the short tube cylindric, the limb spreading, the 4 lobes subequal; stamens 4 , the filaments inserted on the corolla tube, the anthers introrse; ovary sessile, unilocular; ovules 4, on a central placenta; style short, bilobate; fruit capsular, oblique, apiculate; seeds pendulous, without endosperm, usually germinating in the capsule.

Three or four species, widely distributed in tropical regions in coastal swamps. Although only one species is known from Guatemala, two are treated here, as $A$. bicolor Standley has been collected in Mexico, El Salvador, Honduras, and Panama, and may be expected here.

This genus is placed by some authors in a separate family, Avicenniaceae.

Leaves broadly elliptic to elliptic-ovate or ovate; flowers opposite, each pair 5$8 \mathrm{~mm}$. distant from the next pair on the rachis; corolla lobes glabrous inside; style nearly obsolete, ca. $0.5 \mathrm{~mm}$. long at anthesis............. bicolor.

Leaves oblong or oblong-lanceolate; flowers congested at ends of rachises; corolla lobes sericeous inside; style $1-2 \mathrm{~mm}$. long at anthesis.......... . germinans.

Avicennia bicolor Standl. Journ. Wash. Acad. Sci. 13:354. 1923.

Swampy areas, sea level to 90 meters; Mexico (Chiapas); Honduras; El Salvador; Costa Rica (fide Moldenke); Panama (type from Aguadulce, Coclé, Panama, Pittier 4968). 
Shrubs or trees to $13 \mathrm{~m}$. tall; trunk to $30 \mathrm{~cm}$. in diameter; young branchlets glabrous; leaves on stout petioles $4-15 \mathrm{~mm}$. long, the blades entire, broadly elliptic to ovate, 5-13 cm. long, 3-7 cm. wide, rounded or obtuse at the apex, the base usually cuneate or acute, often abruptly short-decurrent, glabrous above, densely and finely pulverulent beneath; inflorescences spicate, tomentulose, the numerous rachises forming pedunculate panicles $5-17 \mathrm{~cm}$. long; the flowers opposite, sessile, each pair 5-8 mm. distant from the next; bracts and bractlets ovate, usually rounded and obtuse, tomentulose; corolla tube $2-3 \mathrm{~mm}$. long, glabrous, the lobes 2-4 mm. long, obtuse to truncate, one or two of ten bifid, sericeous outside, glabrous inside; style $0.5 \mathrm{~mm}$. long at anthesis, elongating to only $1 \mathrm{~mm}$. by the time the corolla falls; capsule obliquely oblong-ovate, $2-3 \mathrm{~cm}$. long, pale green, very finely pubescent.

This species closely resembles $A$. schaueriana Stapf \& Leechman of the West Indies and South America, which differs only in having fewer, more congested, less complex inflorescences. If they should prove to be synonymous, the name $A$. bicolor Standley takes precedence.

Called "mangle negro" in El Salvador.

Avicennia germinans (L.) L. Sp. Pl. ed. 3. 2: 891. 1764, pro parte typica; P. Br. Civ. Nat. Hist. Jam. ed. 2, index I: 12, II: 7. 1789; Stearn, Kew Bull. 1958: 34. 1958; Compère, Taxon 12: 150. 1963. Bontia germinans L. Syst. Nat. ed. 10: 1122. 1759; Sp. Pl. ed. 2, 2: 891. 1763, pro parte typica. Avicennia nitida Jacq. Enum. Pl. Carib. 25. 1760. A. africana P. Beauv. Fl. Oware 1: 79-80, t. 47. 1806. Black mangrove (British Honduras).

Common at or near sea level, in salt marshes, tidal flats, mangrove swamps of both coasts; Escuintla; Izabal; Retalhuleu; San Marcos. Florida; Mexico; British Honduras to Panama; along seashores of South America and the Old World tropics.

Large shrubs or small trees, said to sometimes attain a height of $15 \mathrm{~m}$., usually smaller in Central America; the bark shallowly fissured, dark, orange-red within, the young branchlets pale, densely and minutely puberulent; leaves on short, stout petioles, the blades coriaceous, oblong or oblong-lanceolate, $3-12 \mathrm{~cm}$. long, 1-4 cm. wide, obtuse or acute, acute or attenuate to the base, grayish above and glabrous or finely pubescent or puberulent, whitish or grayish beneath, and densely and minutely pulverulent beneath, the veins usually conspicuous; inflorescences short, forming panicles $2-5 \mathrm{~cm}$. long, the flowers sessile, glomerate at the ends of the rachises; bracts and bracteoles ovate-acute, imbricate; corolla greenish, cream, or white, the tube $3-4 \mathrm{~mm}$. long, glabrous, the lobes $3-5 \mathrm{~mm}$. long, rounded, sericeous inside and outside, one lobe of ten bifid; style usually 1-2 mm. long at anthesis, sometimes attaining $3 \mathrm{~mm}$. by the time the corolla falls; capsule obliquely oblong, ovate, or oblong-ovate, laterally compressed, $2-3(4) \mathrm{cm}$. long, pale green, finely pubescent. 


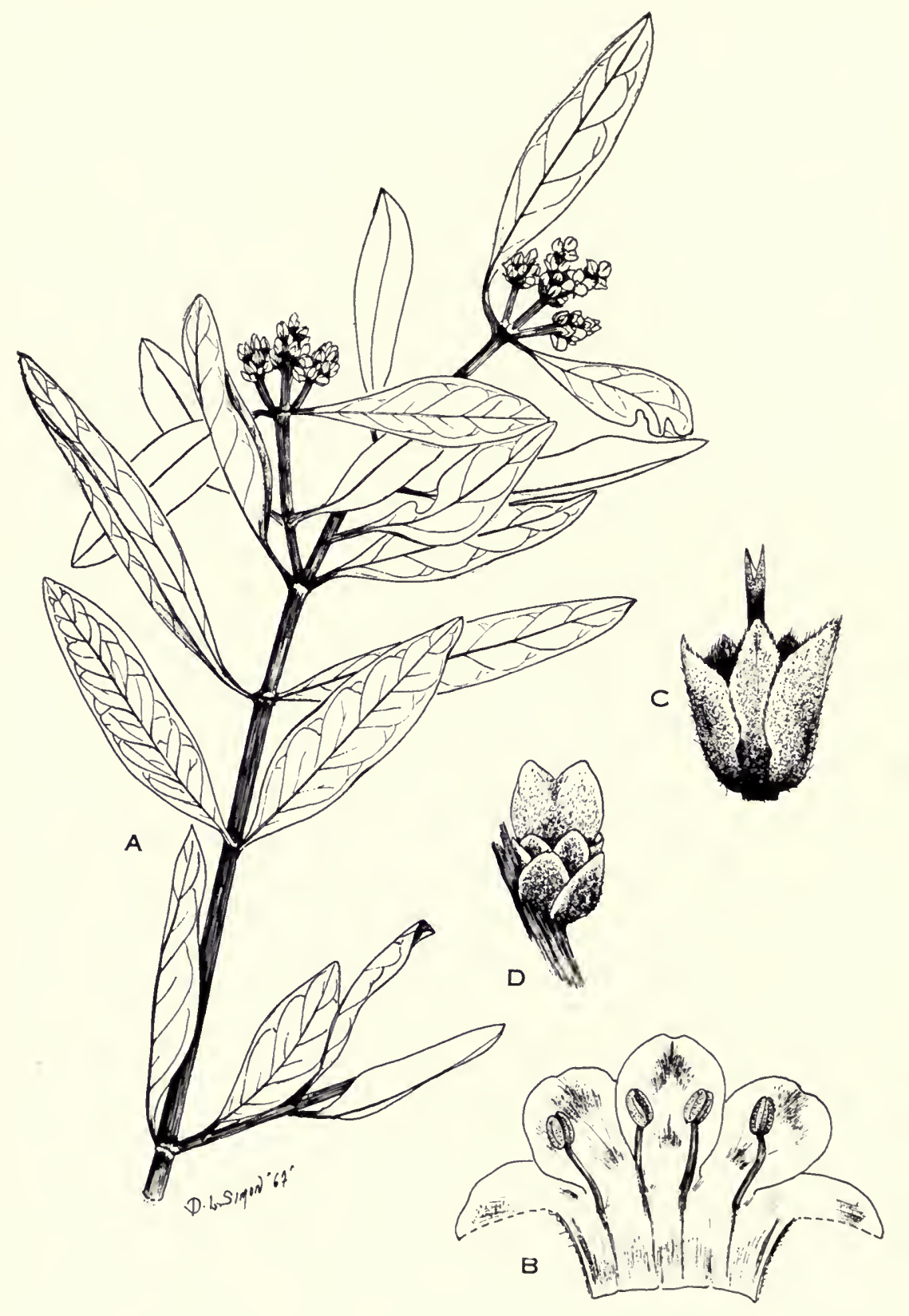

FIG. 32. Avicennia germinans. A, habit, 1/2 natural size; B, corolla dissected to show stamens, $\times 4 ; \mathrm{C}$, calyx showing style and stigma, $\times 4 ; \mathrm{D}$, flower bud showing subtending bracts and indicating sericeous pubescence, $\times 3$. 
Although the corollas have been described by some authors as 10-20 mm. long, I have seen none more than $8.5 \mathrm{~mm}$.

This is one of the plants that characterize most tropical seashores. In Guatemala it is one of the most abundant trees of coastal swamps. The long, heavy roots grow in entangled arches, making almost impassable obstructions, and send to the surface of the mud large masses of irregular asparagus-like aerial roots. The seeds usually germinate on the tree and are growing and ready to take root when they fall into the tidal mud. The flowers are said to be much visited by bees and to supply a good grade of honey.

\section{BOUCHEA Chamisso}

References: Myrle Grenzebach, A revision of the genus Bouchea (exclusive of Chascanum), Ann. Mo. Bot. Gard. 13: 71-90, t. 8-12. 1926 ; Harold N. Moldenke, A monograph of the genus Bouchea. II, in Fedde, Rep. Sp. Nov. 49: 91-139. 1940.

Annual or perennial herbs, erect, glabrous or pubescent; leaves petiolate or sessile, serrate, crenate dentate, or rarely incised, dissected, or entire; inflorescence racemose or spicate, terminal or axillary, elongated, densely or laxly flowered, bracteate; flowers short pedicellate, subsessile or sessile; bracts usually narrowly linear-lanceolate; calyx persistent, tubular, 5-costate, the costae terminating in more or less unequal teeth; corolla blue, lavender, rose, or purple, funnelform, the tube straight or curved, the limb oblique, spreading, the 5 lobes unequal, the 2 posterior lobes shorter than the anterior ones; stamens 4, didynamous, included, the filaments short, inserted on the corolla tube; anthers with 2 cells, ovate or subcordate; ovary bilocular, each locule uniovulate; style filiform, the stigma bilobate; fruit dry, linear, rostrate, included in the calyx or exserted, separating at maturity into 2 cocci.

Ten species, one in Abyssinia, the others in tropical America. Only the following species have been found in Central America.

Mature fruit 14-17 mm. long; beak 4-7 mm. long, densely puberulent; calyx conspicuously pubescent. B. nelsonii.

Mature fruit 6-12 mm. long; beak less than $4 \mathrm{~mm}$. long, glabrous or (rarely) only sparsely and minutely puberulent; calyx puberulent or glabrate.

Fruit less than $10 \mathrm{~mm}$. long.

Fruit $8-9.5 \mathrm{~mm}$. long; beak ca. $1.5 \mathrm{~mm}$. long. ............ prismatica. Fruit 6-7 mm. long; beak $0.5 \mathrm{~mm}$. long or less. .B. prismatica var. brevirostra. Fruit 10-12 mm. long; beak 2-3 mm. long. . . . . R. prismatica var. longirostra.

Bouchea nelsonii Grenzebach, Ann. Mo. Bot. Gard. 13: 83. 1926. Verbena.

Brushy, rocky slopes or plains, 150-800 meters; Huehuetenango; Zacapa. Mexico (Oaxaca and Chiapas); Honduras. 
Plants erect, stout, usually $16-60 \mathrm{~cm}$. tall, rarely to $80 \mathrm{~cm}$., simple or sparsely branched, densely and finely pubescent throughout, the stems terete below, obtusely tetragonal above; leaves on petioles 1-7 $\mathrm{cm}$. long, the blades membranaceous, broadly ovate, $2-6 \mathrm{~cm}$. long, $1-4.5 \mathrm{~cm}$. wide, acute or rounded at the apex, broadly cuneate to subtruncate at the base, the margins coarsely serrate; racemes terminal or axillary, up to $26 \mathrm{~cm}$. long when mature, usually densely flowered, the flowers short-pedicellate or subsessile; bracts linear, 5-6 mm. long; calyx very narrow, 7-9 mm. long at anthesis, $13-15 \mathrm{~mm}$. long in fruit, pubescent, the teeth $2-$ $3 \mathrm{~mm}$. long; corolla blue, rose, or purple; mature fruit 14-17 mm. long, linear, the beak about one-third the total length, 4-7 $\mathrm{mm}$. long, densely puberulent.

Bouchea prismatica (Jacq.) Kuntze, Rev. Gen. 2: 502. 1891. Verbena prismatica Jacq. Coll. Bot. 2: 301. 1788. B. ehrenbergii Cham. Linnaea 7: 253. 1832. Verbena.

Damp or wet fields, near sea level to 1,200 meters; Petén. Southern Arizona; Mexico; Honduras; West Indies; northern South America.

Plants erect, to $60 \mathrm{~cm}$. tall, simple or sparsely branched, the stems terete or subtetragonal, pubescent or glabrate; leaves on petioles $1-6 \mathrm{~cm}$. long, the blades ovate to broadly ovate, $2-8 \mathrm{~cm}$. long, $1-4.5 \mathrm{~cm}$. wide, obtuse or acute, broadly cuneate at the base, serrate to crenate-dentate, sparsely and finely pubescent on both surfaces; racemes mostly terminal, 6-25 $\mathrm{cm}$. long, densely or laxly flowered, the flowers subsessile; bracts linear-lanceolate, $2-4 \mathrm{~mm}$. long; calyx puberulent or glabrate, 4-6 mm. long at anthesis, 5-9 mm. long in fruit, the teeth 1-2 mm. long; corolla blue, rose, or purple; fruit linear, terete, $8-9.5 \mathrm{~mm}$. long, the beak typically $1.5 \mathrm{~mm}$. long and glabrous, rarely minutely puberulous.

Plants of this species usually wither when the rains end and are seldom seen during the dry months.

B. prismatica var. brevirostra Grenzebach, Ann. Mo. Bot. Gard. 13: 80. 1926 (type from Michoacan, Mexico, Arsene 2857). Shep-uón (Huehuetenango).

Damp fields, grassy slopes, vacant lots, 800-1,900 meters; Huehuetenango; Santa Rosa. New Mexico; Mexico; El Salvador; West Indies.

Differs from the typical variety in its shorter fruit, 6-7 $\mathrm{mm}$. long, shorter calyx, 4-6 mm. long, and especially in its very short, sometimes inconspicuous beak, $0.5 \mathrm{~mm}$. long or less.

B. prismatica var. longirostra Grenzebach, Ann. Mo. Bot. Gard. 13: 81. 1926 (type from Jamacia, Harris 11792).

Damp fields, roadsides, 600 meters or less; British Honduras. Southern Mexico; Honduras; West Indies; northern South America. 


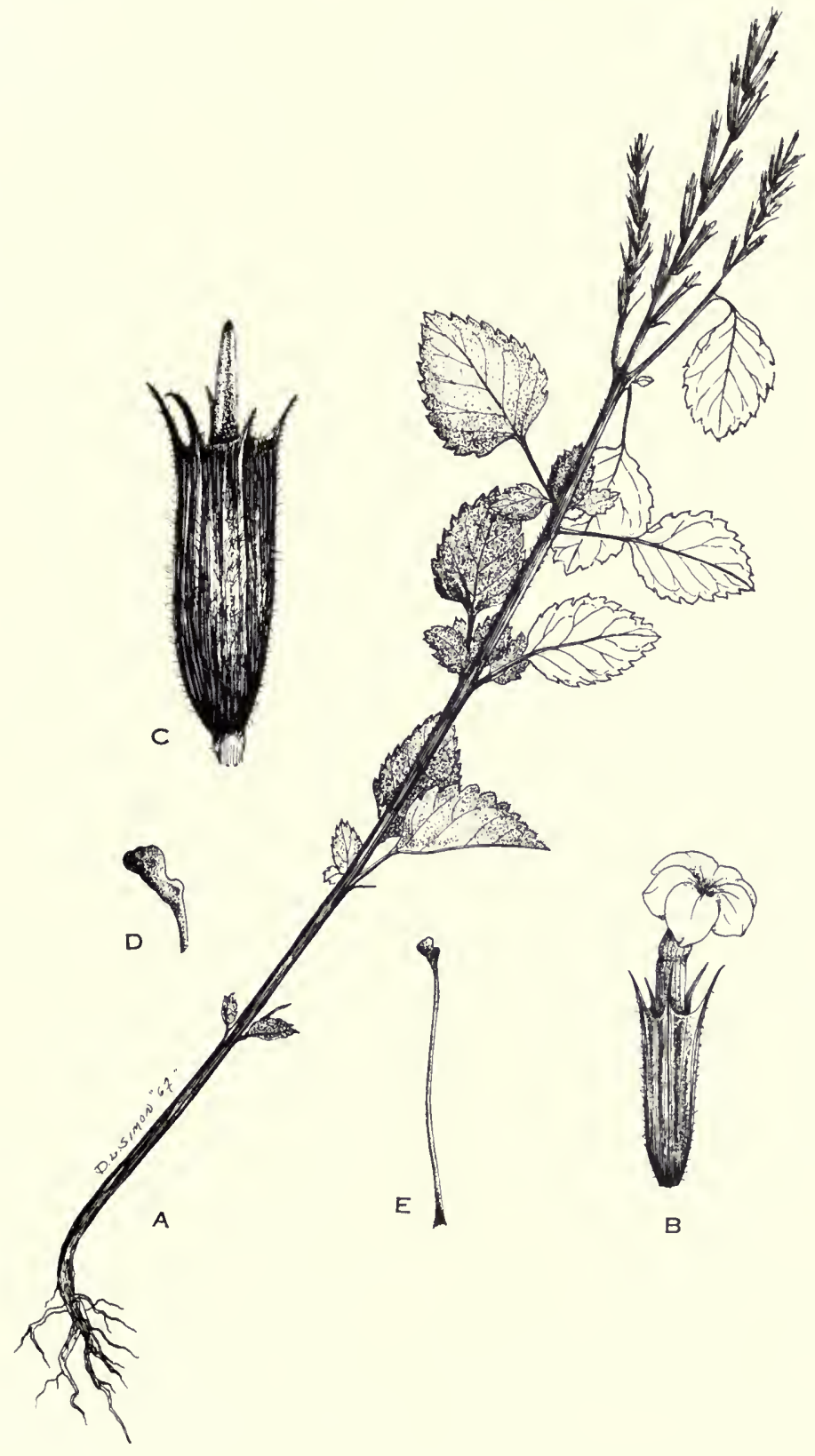

FIG. 33. Bouchea nelsonii. A, habit, $1 / 2$ natural size; $\mathrm{B}$, flower, $\times 3$; C, caly $\mathrm{x}$ enclosing fruit, $\times 3 ; \mathrm{D}$, detail of stigma, $\times 15$; , style and stigma, $\times 5$. 
Differs from the typical variety in its longer fruits, $10-12 \mathrm{~mm}$. long, fruiting calyx 8-11 mm. long, and much longer beak, 2-3 mm long.

\section{CALLICARPA L.}

Reference: Moldenke, H. N. A monograph of the genus Callicarpa as it occurs in America and in cultivation, in Fedde, Rep. Sp. Nov. 39: 288-317. 1936; 40: 38-131. 1936.

Trees or shrubs, the indument of ten of stellate or dendroid hairs; leaves opposite, simple, without stipules; inflorescences cymose, axillary or supra-axillary; flowers usually polygamous, small, actinomorphic; calyx at anthesis tubular or campanulate, in fruit patelliform, with 4 lobes or teeth, or entire; corolla funnelform or salverform, the tube straight, ampliate above, the limb usually with 4 subequal lobes, spreading; stamens 4 or rarely 5, the filaments filiform, glabrous, inserted at or near the base of the corolla tube, usually exserted, anthers oblong or elliptic, dorsifixed near the base, extrorse; style capillary, simple, glabrous, the stigma capitate or peltate; ovary composed of 2 bilocular carpels, each carpel uniovulate; fruit drupaceous, with a fleshy exocarp and hard endocarp, this separating into 4 or by abortion fewer pyrenes; embryo straight; endosperm scant or none.

More than 100 species, widely dispersed in tropical regions of both continents. Only one species is known in Central America.

Callicarpa acuminata HBK. Nova Gen. \& Sp. 2: 252. 1817. Ceniciento (Petén); fruta de chacha (Izabal).

On sand bars along streams, in wet to dry thickets or open forest, sometimes in second growth, near sea level to 1,200 meters; Alta Verapaz; Chiquimula; Guatemala; Izabal; Petén; Zacapa. Mexico; British Honduras along the Atlantic lowlands to Panama; southward to Bolivia.

Shrubs or small trees, usually not more than $5 \mathrm{~m}$. tall, the branchlets densely tomentose with stellate and dendroid hairs; leaves on petioles $0.5-3 \mathrm{~cm}$. long, the blades membranaceous or chartaceous, broadly ovate to lance-oblong or oblongelliptic, 8-25 cm. long, 2.5-11 cm. wide, long-acuminate, acute or acuminate at the base, closely serrate or subentire, dark green above in age and sparsely stellate tomentose, at least along the veins, pale and densely tomentose with stellate and dendroid hairs beneath; inflorescences of numerous pedunculate cymes, appearing corymbiform, borne in the upper leaf axils, usually less than half as long as the leaves, densely flowered; flowers slightly fragrant, the pedicels $1-3 \mathrm{~mm}$. long; calyx campanulate, ca. $1 \mathrm{~mm}$. long, subtruncate, minutely papillate and very sparsely pubescent; corolla white, the tube $1.5-2.5 \mathrm{~mm}$. long, the lobes scarcely $1 \mathrm{~mm}$. long; stamens exserted; ovary glabrous; style glabrous, long-exserted; fruit dark purple, subglobose, juicy, 2-4 mm. long.

In Yucatan, called "zacpukim" or "xpucyim" (Maya). 


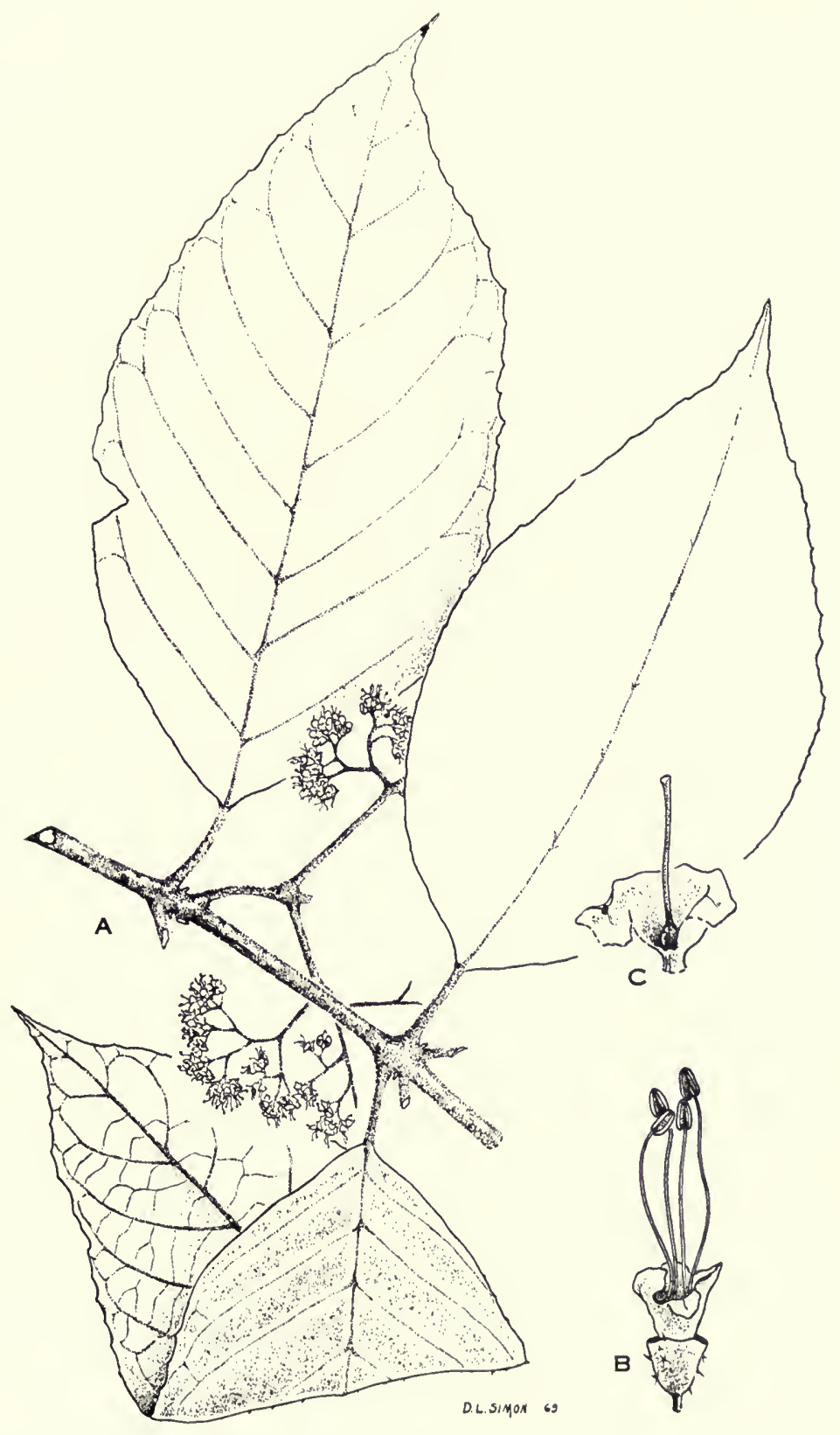

FIG. 34. Callicarpa acuminata. A, section of flowering branch, $1 / 2$ natural size; $\mathrm{B}$, flower, $\times 5$; C, calyx opened to show pistil, $\times 10$. 


\section{CITHAREX YLUM I.}

'Trees or shrubs, the branchlets usually tetragonous, rarely armed with spines; leaf scars of ten large, corky, and elevated; leaves opposite or verticillate, estipulate, entire or dentate, usually with 1 or 2 or more glands at the base of the blade; inflorescences racemose or spicate, axillary and terminal, commonly elongated and many-flowered, erect or nutant; flowers small, each subtended by an inconspicuous bract; calyx at anthesis tubular or cupuliform, in fruit enlarged and indurated, cupuliform or patelliform, the margin truncate or with 5 teeth or lobes; corolla funnelform or salverform, white or yellowish, the limb spreading, the 5 lobes subequal, usually pubescent in the throat; stamens 4, didynamous, inserted at or above the middle of the corolla tube, included, a fifth stamen represented by a rudimentary staminode, filaments very short, the anthers ovate or sagittate, introrse; style of ten thickened toward the apex, the stigma shallowly bifid; ovary with 4 perfect or imperfect locules, each locule with one lateral anatropous ovule; fruit drupaceous, exceeding the calyx, with juicy exocarp and hard endocarp, containing 2 bilocular pyrenes, each with 2 seeds.

More than 100 species, all in tropical and subtropical America. Only ten occur in Guatemala but additional species are known from other parts of Central America.

Indument of stellate hairs.

Bracts of inflorescence minute and inconspicuous, 1-2 (3) $\mathrm{mm}$. long.

Bracts of inflorescence conspicuous, $4-25 \mathrm{~mm}$. long.

C. mocinnii.

Indument of simple hairs.

C. mocinniii var. longibracteolatum.

Corollas lavender, 8-11 mm. long; angles of branches usually narrowly winged or at least winglike........................ pterocladum.

Corollas white, 4-7 mm. long; angles of branches not winged nor winglike.

Calyx at anthesis somewhat striate to conspicuously multistriate.

Lower leaf surface glabrous or obscurely puberulent; calyx $3-3.5 \mathrm{~mm}$. long.

C. hexangulare.

Lower leaf surface pubescent, pilose on costa and veins; calyx 5-7 mm. long.

Calyx at anthesis 5-costate.

C. guatemalense.

Calyx conspicuously 5-lobate, even in fruit, the lobes ca. $1 \mathrm{~mm}$. long; costa and veins of lower leaf surface pilose with hairs ca. $1 \mathrm{~mm}$. long.

C. cooperi.

Calyx sinuately 5-dentate, remotely denticulate, irregularly torn or truncate; costa and veins of lower leaf surface not pilose.

Calyx at anthesis 4-7 mm. long (4 mm. in the short-styled flowers, $4.5-7$ $\mathrm{mm}$. in the long-styled flowers); fruiting calyx campanulate, closely investing the mature fruit for half its length or more..C. hirtellum.

Calyx at anthesis less than $4 \mathrm{~mm}$. long; fruiting calyx cupuliform to patelliform, not closely investing the mature fruit.

Lower leaf surface densely and finely pubescent; calyx more or less pubescent. ..................... crassifolium.

Lower leaf surface glabrous or only minutely puberulent; calyx glabrous or minutely puberulent.

Leaf blades mostly broadest below the middle, usually long-acuminate at apex; calyx sinuately 5-dentate or denticulate.

C. donnell-smithii. 
Leaf blades mostly broadest at or above the middle, obtuse, acute, or short-acuminate at apex; calyx truncate.

Leaves typically 3 to 5 times as long as broad, apex usually obtuse, sometimes acute; rachis of inflorescence glabrous.

C. caudatum.

Leaves typically about twice as long as broad, apex usually shortacuminate: rachis of inflorescence puberulent.

C. steyermarkii.

Citharexylum caudatum L. Sp. Pl. ed. 2.872. 1763. C. erectum Sw., Prodr. Veg. Ind. Occ. 91. 1788; Jacq., Ic. Pl. Rar., ed. 2, 3. t. 501. 1793. C. macradenium Greenm. Field Mus. Bot. 2: 188. 1907.

Wet thickets, mangrove swamps, often in second growth, sometimes on pine ridges, at or near sea level; Izabal. Mexico (Chiapas and Tabasco); British Honduras to Panama, along the Atlantic coast; West Indies; northern South America.

Glabrous shrubs or trees, sometimes $10 \mathrm{~m}$. tall (rarely to $20 \mathrm{~m}$.) but of ten flowering when only 1-2 m. tall, the trunk said to attain as much as $13 \mathrm{~cm}$. in diameter; branches and branchlets subterete to tetragonous; leaves on petioles $0.5-2 \mathrm{~cm}$. long, the blades more or less coriaceous, lustrous above, elliptic or narrowly elliptic-oblong, usually broadest above the middle, 5-17 cm. long, 1.5-5.5 $\mathrm{cm}$. wide, usually obtuse, but some leaves of ten acute, acute at the base, the basal margins usually recurved and enclosing 2 dark, elongated glands; racemes axillary or terminal, erect or pendant, solitary or forming lax panicles, $3-40 \mathrm{~cm}$. long, usually densely flowered; rachis glabrous; pedicels $1-2.5 \mathrm{~mm}$. long, the bracts minute, triangular or subulate; calyx campanulate, $2-3.5 \mathrm{~mm}$. long, glabrous, 5-costate, subtruncate, remotely denticulate, in fruit broadly and shallowly cupuliform; corolla white, the tube $3-4 \mathrm{~mm}$. long, glabrous, the lobes 1-2 $\mathrm{mm}$. long, glabrous or minutely puberulent outside, puberulent inside; ovary glabrous, the style minutely puberulent; fruit ovoid or subglobose, lustrous, yellow or orange to red at first, purple black at maturity, to $12 \mathrm{~mm}$. long.

Called "bird-seed" and "pigeon-feed" in British Honduras.

\section{Citharexylum cooperi Standl. Trop Woods 10: 50. 1927.}

In Guatemala, known only from Izabal, along Río Tameja, alt. 50 meters. Panama.

Small trees, 7-8 m. tall, the branchlets quadrangular, pubescent or glabrate; leaves on petioles 6-15 mm. long, the blades ovate to oblong-elliptic, 6-14 cm. long, acuminate, acute and sometimes decurrent to the base, entire, subcoriaceous, essentially glabrous above, softly pubescent below, pilose along the costae and veins below, lateral veins $5-9$ pairs; inflorescence paniculate, the racemes branching, 2-10 cm. long, densely flowered, the rachis short hirsute to hirtellous; bracts subulate, equalling or exceeding the pedicels; calyx narrowly campanulate, $3-3.5 \mathrm{~mm}$. long, sparsely hirtellous, 5 -costate, the 5 lobes ovate; corolla tube ca. $2.5 \mathrm{~mm}$. long, glabrous outside, the lobes minutely puberulent on both surfaces; fruits subglobose, 6-7 $\mathrm{mm}$. long. 
Called "wild lime" in Panama.

Citharexylum crassifolium Greenm. Field Mus. Bot. 2: 186. 1907.

Damp or dry mixed forest, 1,500-2,000 meters; Baja Verapaz (type from Santa Rosa, Tuerckheim 1308); Chimaltenango; Zacapa. Mexico (Chiapas); British Honduras.

Shrubs or small trees, sometimes $9 \mathrm{~m}$. tall, the branches subterete or tetragonous, stout and stiff, the young ones usually densely pubescent; leaves on petioles 0.5-2 cm. long, the blades rigid-coriaceous, oblong, oblong-elliptic, or obovate, 5-15 cm. long, 2-8 cm. wide, entire or rarely (probably abnormally) coarsely serrate near the apex, short acuminate to obtuse, acute at the base or rounded and abruptly decurrent, essentially glabrous above, densely and finely pubescent beneath with spreading hairs, the veins elevated, the lateral ones 5-8 pairs; racemes simple, 5-15 cm. long, usually few flowered, the rachis hirtellous or puberulent; the bracts minute; pedicels $1-3 \mathrm{~mm}$. long; calyx at an thesis narrowly campanulate, $2-3 \mathrm{~mm}$. long, more or less pubescent, with 5 costae terminating in 5 very short teeth, fruiting calyx broadly and shallowly cupuliform, truncate; corolla white, the tube 3-4 mm. long, glabrous, the lobes 1.5-2 mm. long, pubescent on both surfaces; fruit obovoid-globose, 7-8 mm. long or more, first yellow, doubtless black at maturity.

Citharexylum donnell-smithii Greenm. Field Mus. Bot. 2: 186. 1907. C. recurvatum Greenm. op. cit. 189 (type from Costa Rica, Cooper 5889). Coralillo (Guatemala and Sacatepéquez); cuul, chuul (Quezaltenango).

Damp, mixed forest, sometimes in oak and pine forest, often seen along roadsides, sometimes planted, 1,000-2,700 meters; Escuintla; Guatemala (type from Volcán de Pacaya, J. D. Smith 1879); Quezaltenango; Sacatepéquez; San Marcos; Suchitepéquez; Zacapa. Southern Mexico; Honduras; El Salvador; Costa Rica; Panama.

Trees, glabrous throughout, of ten $15 \mathrm{~m}$. tall with a trunk to $70 \mathrm{~cm}$. in diameter, sometimes flowering when only 2 or $3 \mathrm{~m}$. tall, the branches subterete; leaves on petioles 1-3 cm. long, the blades coriaceous, lustrous, lanceolate or lance-oblong, usually broadest below the middle, $8-20 \mathrm{~cm}$. long, $2-5.5 \mathrm{~cm}$. wide, long acuminate, acute at the base, glabrous on both surfaces; racemes $5-35 \mathrm{~cm}$. long, of ten forming lax panicles; rachis usually glabrous, sometimes puberulent; pedicels $1-3 \mathrm{~mm}$. long, the bracts minute, subulate; flowers numerous; calyx tubular-campanulate, 2-3.5 $\mathrm{mm}$. long, 5-costate, sinuately 5-dentate, ciliolate, in fruit cupuliform to patelliform; corolla greenish white to cream, the tube ca. $4 \mathrm{~mm}$. long, glabrous outside, the lobes 1-2 mm. long, glabrous outside, densely pubescent within; ovary glabrous, the style glabrous or minutely puberulent; fruit oblong-globose, 6-7 mm. long, first yellow-orange to red, purple black at maturity. 


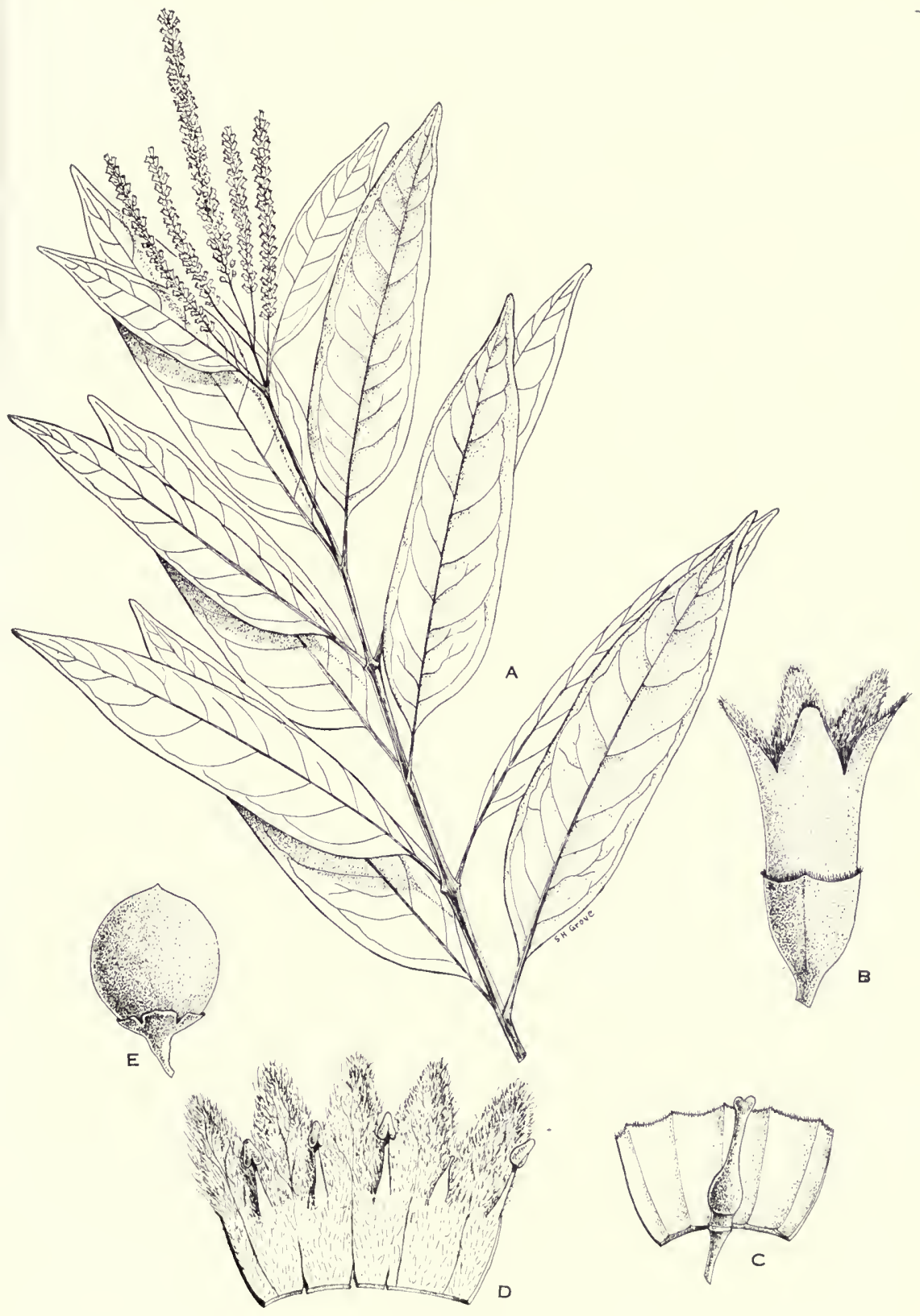

FIG. 35. Citharexylum donnell-smithii. A, habit, 1/2 natural size; B, flower, $\times 10$; C, calyx opened to show pistil, $\times 10$; D, corolla opened to show stamens and staminode, $\times 10 ; \mathrm{E}$, fruit, $\times 2$. 
Citharexylum guatemalense (Moldenke) D. Gibson, Field Mus. Bot. 32. (11) : 176. 1970. C. hirtellum var. guatemalense Moldenke, Phytologia 17: 113. 1968.

Known only from two collections, Steyermark 41818, the type, and Steyermark 41816, both from Izabal, along Río Tameja, alt. 50 meters.

Shrubs or small trees 4-5 m. tall, the branchlets glabrous, tetragonous; leaves on stout petioles 1-2 cm. long, the blades oblong to oblong-ovate, $10-20 \mathrm{~cm}$. long, 4-8 $\mathrm{cm}$. wide, mostly acuminate, some acute, entire, glabrous above, long hirsute to pilose below, sparsely so except along costae and veins, the hairs to $1 \mathrm{~mm}$. long; racemes simple, 10-18 cm. long, somewhat pubescent, densely or remotely flowered; bracts minute; pedicels ca. $2 \mathrm{~mm}$. long; calyx 5-7 mm. long, striate, sparsely pubescent or glabrate, conspicuously 5-lobate, each lobe ca. $1 \mathrm{~mm}$. long; corolla white, essentially glabrous outside, the tube $4-5 \mathrm{~mm}$. long, the lobes ca. $2 \mathrm{~mm}$. long, pubescent within; ovary and style glabrous, the style $2-3 \mathrm{~mm}$. long; fruit obovoidglobose, orange at first, doubtless black at maturity.

Although the flowers of $C$. guatemalense resemble those of the long-styled form of $C$. hirtellum Standley in size of calyx and corolla, the style of $C$. hirtellum is $4-5 \mathrm{~mm}$. long, its calyx is shallowly sinuate and denticulate or irregularly torn, and its leaves are smaller and hirtellous below rather than pilose.

Citharexylum hexangulare Greenm. Field Mus. Bot. 2: 187. 1907.

Wet, mixed forest near sea level to 350 meters; Alta Verapaz (type from Cubilguitz, Tuerckheim 7765); Petén. Southern Mexico; British Honduras; Honduras; Nicaragua.

Trees or shrubs to $12 \mathrm{~m}$. tall, the trunk to $15 \mathrm{~cm}$. in diameter; branchlets mostly acutely quadrangular, the larger ones mostly hexangular, glabrous or nearly so; leaves opposite or sometimes ternate, on slender petioles $0.5-2 \mathrm{~cm}$. long, the blades chartaceous, lanceolate or lance-oblong, sometimes elliptic, 4-16 cm. long, 1-5.5 $\mathrm{cm}$. wide, acute or acuminate at each end, entire, of ten with 2 elongated glands at the base beneath, glabrous above, glabrous or minutely and obscurely puberulent below, lateral veins 5-10 pairs; racemes axillary or terminal, simple or paniculate, mostly erect, $5-30 \mathrm{~cm}$. long, many-flowered, the rachis glabrous or puberulent; pedicels ca. $1 \mathrm{~mm}$. long, the bracts subulate, equalling or exceeding the pedicels; calyx tubular campanulate at anthesis, in fruit first cupuliform, sometimes nearly patelliform in age, $3-4 \mathrm{~mm}$. long, somewhat striate to conspicuously multistriate, essentially glabrous, with 5 teeth or nearly truncate and merely denticulate, ciliolate; corolla white, the tube $3-4 \mathrm{~mm}$. long, glabrous outside, pubescent in throat, the lobes 1-2 mm. long, puberulent outside and inside; style pubescent; fruits ovoid, 6-8 $\mathrm{mm}$. long, first yellow, black when mature. 
The leaves are quite variable; those of some young shoots often very narrow, resembling those of Salix species, while more mature stems may have large, broadly elliptic leaves.

A plant of Costa Rica and Panama, C. viride Moldenke, is very much like $C$. hexangulare and may prove to be synonymous with it. The type of $C$. viride, Cooper \& Slater 157, from Panama, is a fruiting specimen, and the species was described without flowering material. Later collections of flowering material identified by Moldenke as C. viride differ from $C$. hexangulare only in their slightly broader calyces. Although the leaves of $C$. viride are described as densely puberulent beneath, leaves of the type specimen are essentially glabrous beneath or only very minutely pubescent along the lower part of the costae and in the axils of some veins.

Citharexylum hirtellum Standl. Field Mus. Bot. 4: 257. 1929.

On ridges and along creeks, at or near sea level; Izabal; British Honduras (type from Tower Hills, Orange Walk District, J. S. Karling 9).

Shrubs or small trees, the branches acutely quadrangular, hirtellous, or becoming glabrate; leaves on petioles $4-15 \mathrm{~mm}$. long, the blades first chartaceous but usually becoming coriaceous, elliptic or elliptic ovate to elliptic-oblong, acute or acuminate, rarely obtuse, acute at the base, entire, 4-12 cm. long, 3-6 cm. wide, with 5-7 pairs of lateral veins, finely hirtellous above at first, becoming glabrate, sparsely or densely hirtellous below; racemes simple, pedunculate, erect or pendant, 4-14 cm. long, the rachis densely hirtellous, many flowered, the flowers of 2 forms; pedicels ca. $1 \mathrm{~mm}$. long at anthesis, $2 \mathrm{~mm}$. long in fruit; bracts linear subulate, 1-2 $\mathrm{mm}$. long, or the lower ones sometimes elongated and 3-5 $\mathrm{mm}$. long; calyx tubular campanulate, sparsely hirtellous, 5-costate at anthesis, remotely denticulate or irregularly torn, ca. $4 \mathrm{~mm}$. long in the short-styled flowers, $4.5-7 \mathrm{~mm}$. long in the long-styled flowers, fruiting calyx campanulate, closely investing the fruit, 4-7 mm. long; corolla white, ca. $6 \mathrm{~mm}$. long in the short-styled flowers, $7-8 \mathrm{~mm}$. long in the long-styled flowers, the tube glabrous outside, pubescent within, the lobes minutely puberulent outside, puberulent within; ovary glabrous, style minutely pubescent, those of the small flowers ca. $3 \mathrm{~mm}$. long, those of the larger flowers $4-5 \mathrm{~mm}$. long; fruit ovoid, $8-10 \mathrm{~mm}$. long, first red, doubtless black at maturity.

This has sometimes been confused with $C$. cooperi Standley, perhaps partly because $C$. hirtellum was not understood to be heterostylous. The calyx of $C$. cooperi, which is $3-4 \mathrm{~mm}$. long, is always conspicuously and evenly dentate. In addition, the racemes of C. cooper $i$ branch to form short panicles, $2-8 \mathrm{~cm}$. long, and the leaves usually have 8-10 pairs of lateral veins. 
Citharexylum mocinnii D. Don, Edinb. New Phil. Journ. 11: 238. 1831 (type from Mexico). C. rugendasii Cham., Linnaea 7:120. 1832. C. rugendasii var. endlichii Loes. in Fedde, Rep. Sp. Nov. 9: 367. 1911. C. lankesteri Moldenke in Fedde, Rep. Sp. Nov. 37: 229. 1934.

Damp mountain forest, 1,500-2,300 meters; Guatemala; Quezaltenango; El Quiché; Sacatepéquez. Southern Mexico; Honduras; El Salvador; Nicaragua; Costa Rica.

Trees to $18 \mathrm{~m}$. tall, to $60 \mathrm{~cm}$. in diameter, the branches usually stout, tetragonous, stellate-tomentose or in age glabrate; leaves on stout petioles 1-6 cm. long, the blades thick membranaceous to subcoriaceous, broadly ovate, oblong-ovate, oblong-elliptic, lanceolate-ovate, or lanceolate, acute to acuminate (rarely obtuse), the base rounded, acute, or cuneate, margins normally entire but rarely coarsely dentate near the apex, 6-30 cm. long, 3-15 cm. wide, glabrate above except along the costae and veins, pale or yellowish beneath and usually densely stellate tomentose, the lateral veins prominent beneath; racemes solitary or forming panicles, erect or pendent, many flowered, 6-30 $\mathrm{cm}$. long, densely stellate-tomentose, the pedicels short and thick, the bracts subulate, to $3 \mathrm{~mm}$. long; flowers fragrant; calyx tubular-campanulate at anthesis, $2.5-4 \mathrm{~mm}$. long, pubescent or glabrate, the 5 costae-terminating in 5 remote, very small teeth, fruiting calyx ultimately patelliform, 6-7 mm. broad; corolla white, to $7 \mathrm{~mm}$. long, the tube exceeding the calyx, glabrous outside or the lobes somewhat pubescent, densely pubescent within; ovary glabrous, the style minutely puberulent; fruit first subglobose, becoming ovoid, lustrous, first orange or red, black in maturity.

This species is extremely variable in leaf form and size.

Citharexylum mocinnii var. longibracteolatum Moldenke, Phytologia 1: 415. 1940. Caña (Quezaltenango).

Damp forest, 1,500-2,800 meters; Quezaltenango; Sacatepéquez; San Marcos. Southern Mexico; Honduras.

Differs from C. mocinnii only in its persistent, accrescent, conspicuous bracts which may be either subulate or' spatulate and are 4-25 mm. long.

Citharexylum pterocladum Donn.-Sm., Bot. Gaz. 33: 255. 1902.

Dense, wet or dry mixed forest, sometimes in Cupressus forest, sometimes in coffee plantations, 200-1,000 meters; Alta Verapaz (type from Cubilgüitz, Tuerckheim 7922); Chimaltenango; Petén; Quezaltenango. Southern Mexico; British Honduras.

Glabrous trees, of ten to $30 \mathrm{~m}$. tall and to $40 \mathrm{~cm}$. in diameter, the crown loosely branched, open, the bark rough, brown, shed in small scales; young branches very thick, acutely quadrangular, the angles narrowly winged or at least winglike, the 
ultimate branchlets often compressed; leaves on slender petioles 1-8 $\mathrm{cm}$. long, the blades membranaceous, oblong-elliptic to ovate-oblong or lance-oblong, 6-29 $\mathrm{cm}$. long, 3-14 cm. wide, acute to long-acuminate, usually cuneate-attenuate to the base but sometimes nearly rounded; racemes usually branching and paniculate but may be solitary, mostly 15-40 cm. long, many-flowered, very slender and lax, apparently somewhat pendent; pedicels ca. $2 \mathrm{~mm}$. long, bracts subulate-triangular, very short; calyx tubular-campanulate, 5-costate, nearly truncate, remotely repand-denticulate, $3-4 \mathrm{~mm}$. long, in fruit indurated, $5-6 \mathrm{~mm}$. broad; corolla pale lavender with darker purple stripes, the tube $5-6 \mathrm{~mm}$. long, glabrous outside, the lobes $4-5 \mathrm{~mm}$. long, glabrous except within at the base; ovary and style glabrous; fruit yellow, probably black at maturity, ovoid-globose, about $8 \mathrm{~mm}$. long.

Closely related to the Mexican C. affine D. Don. Moldenke separates the two by such tenuous characters as whether the branches are "always alate" or "sometimes alate" and the leaf blades "glanduliferous at the base" or "usually not glanduliferous at the base." The only constant difference is the smaller size of the flowers of C. affine, in which the corolla tube is only ca. $4 \mathrm{~mm}$. long with lobes $2-3 \mathrm{~mm}$. long. Because they are so much alike in every other respect, the flowers of both were examined for heterostyly but in both, the stigma at anthesis is just a little below the anthers.

Citharexylum steyermarkii Moldenke, Phytologia 2:14. 1941.

Dense, wet cloud forest, 2,000-2,600 meters, Chiquimula (type from Volcán de Quezaltepeque, Steyermark 31433); Zacapa.

Shrubs or small trees to $8 \mathrm{~m}$. tall, the branches quadrangular or subterete, glabrous, lustrous, the younger branchlets obscurely puberulent; leaves on stout petioles $0.5-2 \mathrm{~cm}$. long, the blades coriaceous or thick-chartaceous, oblong-elliptic, 6-18 cm. long, 3-8 cm. wide, short-acuminate or acute, acute at the base, entire, essentially glabrous above, glabrous or minutely puberulent below, the veins prominent beneath, the lateral veins $7-8$ pairs; racemes simple, 6-18 $\mathrm{cm}$. long, manyflowered, the rachis minutely puberulent; bracts minute; pedicels $1-3 \mathrm{~mm}$. long; calyx campanulate, ca. $3 \mathrm{~mm}$. long, truncate, glabrous or puberulent and ciliolate, in fruit shallowly cupuliform, lustrous; corolla white, the tube $3-4 \mathrm{~mm}$. long, glabrous outside, the lobes $2 \mathrm{~mm}$. long, puberulent outside, densely pubescent inside; fruit $8 \mathrm{~mm}$. long or more, subglobose, greenish-orange, doubtless black at maturity.

It should be noted that the specimen from Zacapa, Steyermark 42845, is atypical. Although Moldenke previously identified it as C. crassifolium Greenm. the lower leaf surface is not densely pubescent, but is minutely and obscurely puberulent. Some of the leaves are three times as long as broad, as in C. caudatum L., but they are short-acuminate at the apex and the rachis of the inflorescence is puberulent as in C. steyermarkii. It may be that $C$. steyermarkii is only a glabrate form of $C$. crassifolium, or both may represent only a broad-leaved form of $C$. caudatum $\mathrm{L}$. 


\section{GLERODENDRUM L.}

Plants herbaceous or woody, often trees or shrubs, sometimes scandent, glabrous or pubescent; leaves opposite or verticillate, the margins entire or dentate; inflorescences cymose, the cymes borne in the upper leaf axils or (in C. fragrans Vent., an exotic species) diposed in terminal, of ten headlike panicles, of ten bracteate; flowers more or less asymmetric, of ten showy, white to blue, violet, or red; calyx usually campanulate, rarely tubular, subtruncate or with 5 teeth or lobes, of ten accrescent and subtending or enclosing the fruit; corolla salverform, the tube straight or curved, of ten much elongated, the limb 5-parted, the lobes subequal or the 2 posterior ones shorter; stamens 4, didynamous, inserted in the corolla tube, long-exserted; anthers ovate or oblong, the cells parallel, opening by longitudinal slits; ovary bicarpellate, imperfectly 4 -locular, each locule uniovulate, the ovules inserted laterally near the apex of the locule; the style terminal, stigma bifid, the lobes short; fruit drupaceous, globose or obovoid, of ten somewhat 4-lobate, the exocarp fleshy, the endocarp bony or crustaceous, smooth or rugose, separating at maturity into 4 pyrenes, or these sometimes coherent in pairs; seeds oblong, without endosperm.

About 350 species in tropical regions of both hemispheres, most abundant in Asia and Africa, with only a few species in America. Two species are native in Guatemala, but three are treated here, as C. fragrans Vent., a native of Asia, has become established in many places. Four plants previously reported from Guatemala as Clerodendrum are omitted, as C. standleyi Moldenke has been referred to the Acanthaceae, and C. pithecobium Standley \& Steyermark, C. mimicum Standley \& Steyermark, and C. moldenkeanum Standley, all with numerous ovules in bilocular ovaries, have been referred to the Scrophulariaceae.

Leaves almost as broad as long, truncate to deeply cordate or (rarely) rounded at the base, the margins coarsely dentate; corollas double, the limb $2.5-3 \mathrm{~cm}$. across . . . . . . . . . . . . . . . . . . . . . . . . . . . . .

Leaves much longer than broad, acute to cuneate-acute at the base, the margins entire or nearly so; corollas single, the limb less than $2 \mathrm{~cm}$. across.

Calyx nearly truncate and dentate; leaves $1-4 \mathrm{~cm}$. long, obtuse or rounded at the apex, lateral veins $3-5$ pairs, of ten obscure............ pittieri.

Calyx deeply 5-lobate, the lobes lanceolate and acuminate; leaves $2-10 \mathrm{~cm}$. long, acute to subacuminate at apex, lateral veins 5-9 pairs, conspicuous.

C. ligustrinum.

Clerodendrum fragrans Vent. Jard. Malm. 2, t. 70. 1804. C. fragrans var. pleniflorum Schauer ex A. DC. in DC. Prodr. 11: 666. 1847. Boca de Amelia (Escuintla); camelia (Zacapa); jasmín (Huehuetenango); jasmin de Amelia (Alta Verapaz); Spanish jasmine (British Honduras).

Native of Asia, widely cultivated in Guatemala and of ten naturalized, forming dense colonies in damp thickets, in waste ground, or 
near dwellings, 200-1,800 meters, Alta Verapaz; Escuintla; Guatemala; Huehuetenango; Izabal; Sacatepéquez; Santa Rosa; Zacapa. Also escaped in Mexico, British Honduras, El Salvador, Costa Rica and West Indies.

Stout shrubs to $1.5 \mathrm{~m}$. tall or almost wholly herbaceous, simple or sparsely branched, the branches stout, obtusely angulate, pubescent; leaves on long, slender petioles, the blades membranaceous, usually broadly ovate, $6-25 \mathrm{~cm}$. long, 5-25 $\mathrm{cm}$. wide, acute or acuminate, the base usually cordate or truncate, sometimes rounded, short-hirtellous, especially beneath, the margins irregularly and coarsely dentate; inflorescences terminal, cymose, often headlike, densely flowered, sessile or short-pedunculate; bracts numerous, oblong or elliptic, foliaceous; calyx campanulate, 1-1.5 cm. long, red or purple, strigillose-puberulent or glabrate, the 5 lobes lanceolate, acuminate; corolla white, of ten tinged with pink or purple, in Central American plants always double, the limb 2.5-3 cm. across.

One of the common ornamental plants of Central American gardens, maintaining itself when neglected, and blooming through the dry months.

All Guatemalan material is referable to var. pleniflorum.

Clerodendrum ligustrinum (Jacq.) R. Br. in Ait. Hort. Kew. ed. 2. 4: 64. 1812. Volkameria ligustrina Jacq. Coll. Bot. Suppl. 118, t. 5, f. 1. 1796. Clerodendron mexicanum Brandegee, Univ. Calif. Pub. Bot. 3: 391. 1909.

Thickets along stream banks or in forest margins, 50-250 meters; Petén. Mexico; British Honduras; Nicaragua; Panama.

More or less scandent, woody shrubs, the branchlets slender or stout, subterete or obtusely angulate, puberulent or glabrate, the foliar scars large and elevated; leaves on petioles 5-14 mm. long, the blades thick-membranaceous, elliptic to elliptic-oblong or elliptic-lanceolate, $2-10 \mathrm{~cm}$. long, 1-5 cm. wide, acute or subacuminate at apex, acute at base, entire, glabrous, densely punctate beneath, the lateral veins 5-9 pairs; inflorescences axillary, sometimes appearing terminal, the cymes pedunculate, of ten lax, 3-7 cm. long, few-flowered, puberulent or glabrate, the bracts few, foliaceous, caducous, the pedicels slender, 3-6 $\mathrm{mm}$. long; calyx campanulate, 6-9 mm. long, deeply 5-lobate, the lobes lanceolate, acuminate, $3-5 \mathrm{~mm}$. long; corolla white, the tube 10-12 $\mathrm{mm}$. long, the 5 lobes subequal, 4-8 $\mathrm{mm}$. long; stamens long-exserted; fruit subglobose, ca. $1 \mathrm{~cm}$. long, splitting into two 2-seeded halves at maturity.

It is reported that in Petén the leaves are used in cooking to flavor fish.

Clerodendrum pittieri Moldenke ex Standl. Field Mus. Bot. 18: 1003. 1938 (without Latin diagnosis); Moldenke, Phytologia 1: 416. 1940. 


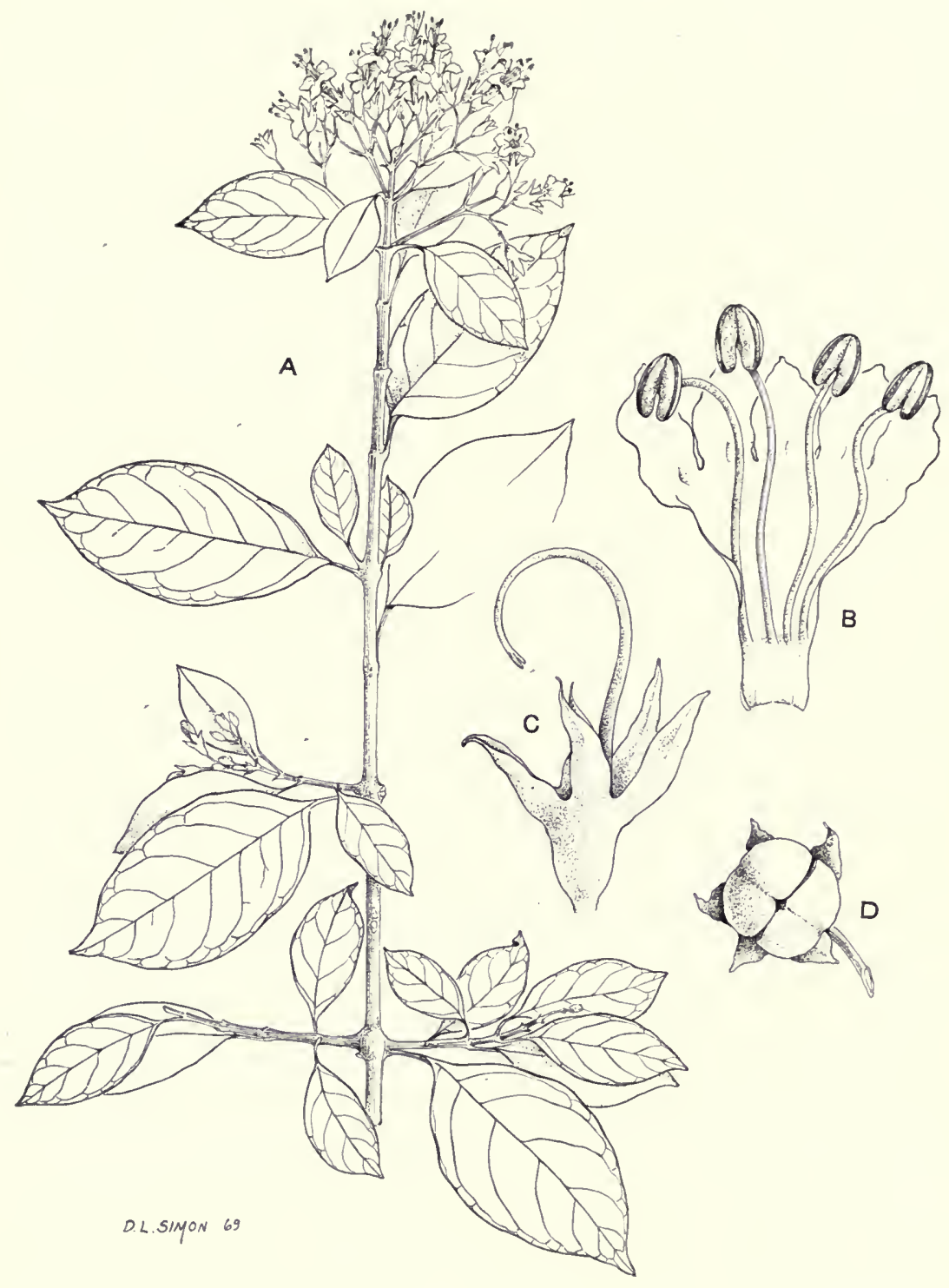

FIG. 36. Clerodendrum ligustrinum. A, habit, 1/2 natural size; B, corolla dissected to show stamens, $\times 3$; C, caly $x$ and style, $\times 3$; D, fruit, $\times 1$. 
Coastal thickets or mangrove swamps; Escuintla; San Marcos. Costa Rica; Panama.

Shrubs of 1-2 m. with stout branches, the young branchlets puberulent or strigillose; leaf scars thickened and pyramidal, of ten somewhat spinelike; leaves on petioles 1-8 mm. long, the blades subchartaceous, oblanceolate-oblong to narrowly elliptic or obovate, 1-4 cm. long and 0.4-2 cm. wide, rounded or obtuse at the apex, cuneate-acute at the base, entire, glabrous, densely punctate beneath, the lateral veins $3-5$ pairs, of ten obscure; inflorescences of solitary axillary cymes, 1-3-flowered, the peduncles to $1 \mathrm{~cm}$. long, the pedicels $5-8 \mathrm{~mm}$. long; calyx $3-5 \mathrm{~mm}$. long, minutely puberulent or glabrate, truncate or nearly so and 5-dentate; corolla white, the tube $2 \mathrm{~cm}$. long, slender, the lobes $4-6 \mathrm{~mm}$. long; fruit subglobose, ca. $5 \mathrm{~mm}$. long.

Closely related to C. aculeatum (L.) Schlecht., which is common from eastern Mexico through the West Indies to northern South America, and which has a smaller calyx tube with definite calyx lobes. It should be noted that no flowering material of $C$. pittieri from Guatemala was seen; the only two Guatemalan collections, both identified by Moldenke, are poor fruiting specimens with only fragmentary calyces and with leaves considerably larger than those of the type of $C$. pittieri. Both might easily be placed in C. aculeatum. It is also interesting that a Field Museum photograph (Neg. No. 24622), of a specimen collected in Peru by Ruiz and Pavón and identified by Moldenke as C. buxifolium (Willd.) Spreng, has the same calyx and corolla as the type of $C$. pittieri.

\section{CORNUTIA Plum. ex L.}

Reference: Harold N. Moldenke, A monograph of the genus Cornutia, in Fedde, Rep. Sp. Nov. 40: 153-205. 1936.

Trees or shrubs with brittle branches and usually abundant pubescence, the branches tetragonous; leaves opposite, petiolate; inflorescences terminal, usually pyramidal-paniculate, the flowers small, zygomorphic; calyx cupuliform to campanulate, or obconic, of ten becoming patelliform in fruit, entire or minutely 4-dentate; corolla salverform, irregular, blue or purple, the tube of ten inflated at the base and ampliate above, straight or curved, the limb spreading, bilabiate, with 4 lobes; 2 fertile stamens inserted in the corolla tube at about the middle, 2 staminodes usually inserted at a point above the middle, the fertile ones usually exserted; filaments usually pubescent, the anthers dorsifixed, the cells widely divergent at the base, dehiscent by longitudinal slits; style terminal, simple, glabrous or pubescent, the stigma bifid, the lobes short; ovary pubescent, composed of 2 bilocular carpels, each locule uniovulate; fruits small, drupaceous, subglobose, the exocarp fleshy and juicy, the endocarp bony, the stone with 4 locules; seeds without endosperm. 
About ten species, in tropical America, usually very showy and attracting attention because of their abundant blue or purple flowers. Two other species are known from southern Central America.

Mature corolla tube abruptly and strongly incurved, $2.5-5 \mathrm{~mm}$. wide, broadest near base and of ten somewhat saccate, the lower lip usually equalling the abaxial side of the tube; style glabrous or minutely pubescent; branchlets, leaves, and inflorescence usually densely velutinous-tomentose.

C. grandifolia.

Mature corolla tube somewhat incurved or nearly straight, 1-3 mm. wide, usually broadest near base but never saccate, the lower lip usually not more than half as long as the abaxial side of the tube; style conspicuously short-pubescent; branchlets, leaves, and inflorescence short-pubescent, puberulent, or tomentulose, often somewhat viscid.

C. pyramidata.

Cornutia grandifolia (Schlecht. \& Cham.) Schauer in DC. Prodr. 11:682. 1847. Hosta grandifolia Schlecht. \& Cham. Linnaea 5: 97. 1830. C. pyramidata var. dentata Kuntze, Rev. Gen. 2: 506. 1891. C. grandifolia var. quadrangularis Moldenke in Fedde, Rep. Sp. Nov. 40: 168. 1936. C. grandifolia var. purpusi Moldenke, op. cit. 169. C. grandifolia var. storkii Moldenke, op. cit. 169 .

Damp thickets or dense forest, often in second growth, 150-1,300 meters; Alta Verapaz; Guatemala; Izabal; Sacatepéquez. Mexico; British Honduras to Panama.

Shrubs or weak trees to $5 \mathrm{~m}$. tall, the branchlets densely velutinous-tomentose with spreading hairs; leaves on stout petioles 1-5 cm. long, the blades ovate, elliptic-ovate or oblong-ovate, 7-30 cm. long, 5-19 cm. wide, acuminate, attenuate to the base and decurrent, usually densely velutinous-tomentose on both surfaces, more densely so beneath (rarely only sparsely puberulent), the margins usually dentate, rarely entire; inflorescences terminal, paniculate, $15-40 \mathrm{~cm}$. long, the flowers numerous, short-pedicellate, the cymes pedunculate, rachis, peduncles and pedicels usually velutinous-tomentose; calyx at anthesis shallowly cupuliform and truncate, sometimes obscurely toothed, 1-2.5 mm. long, densely short-pubescent, in fruit usually patelliform, sometimes shallowly cupular; corolla light blue to deep purple, puberulent, the tube abruptly and strongly incurved, 6-9 $\mathrm{mm}$. long, 2.5-5 mm. wide, broadest near the base and of ten more or less saccate, the lower lip of the limb almost as long as the abaxial side of the tube; ovary densely pubescent, style glabrous or minutely pubescent; fruits subglobose, $3-5 \mathrm{~mm}$. long, puberulent or pubescent.

Cornutia pyramidata L. Sp. Pl. 628. 1753. Hosta pyramidata A. Dietr. in Willd. Sp. Pl. 1, 253. 1831. Hosta latifolia HBK. Nova Gen. \& Sp. 2:248. 1817. Cornutia latifolia Moldenke in Fedde, Rep. Sp. Nov. 40: 179. 1936. C. grandifolia var. intermedia Moldenke, op. cit. 167. C. lilacina Moldenke, op. cit. 181 (type from Gualan, Guatemala, Deam 6383). C. lilacina var. velutina Moldenke, op. cit. 183. C. pyramidata var. isthmica Moldenke, op. cit. 187. C. lati- 


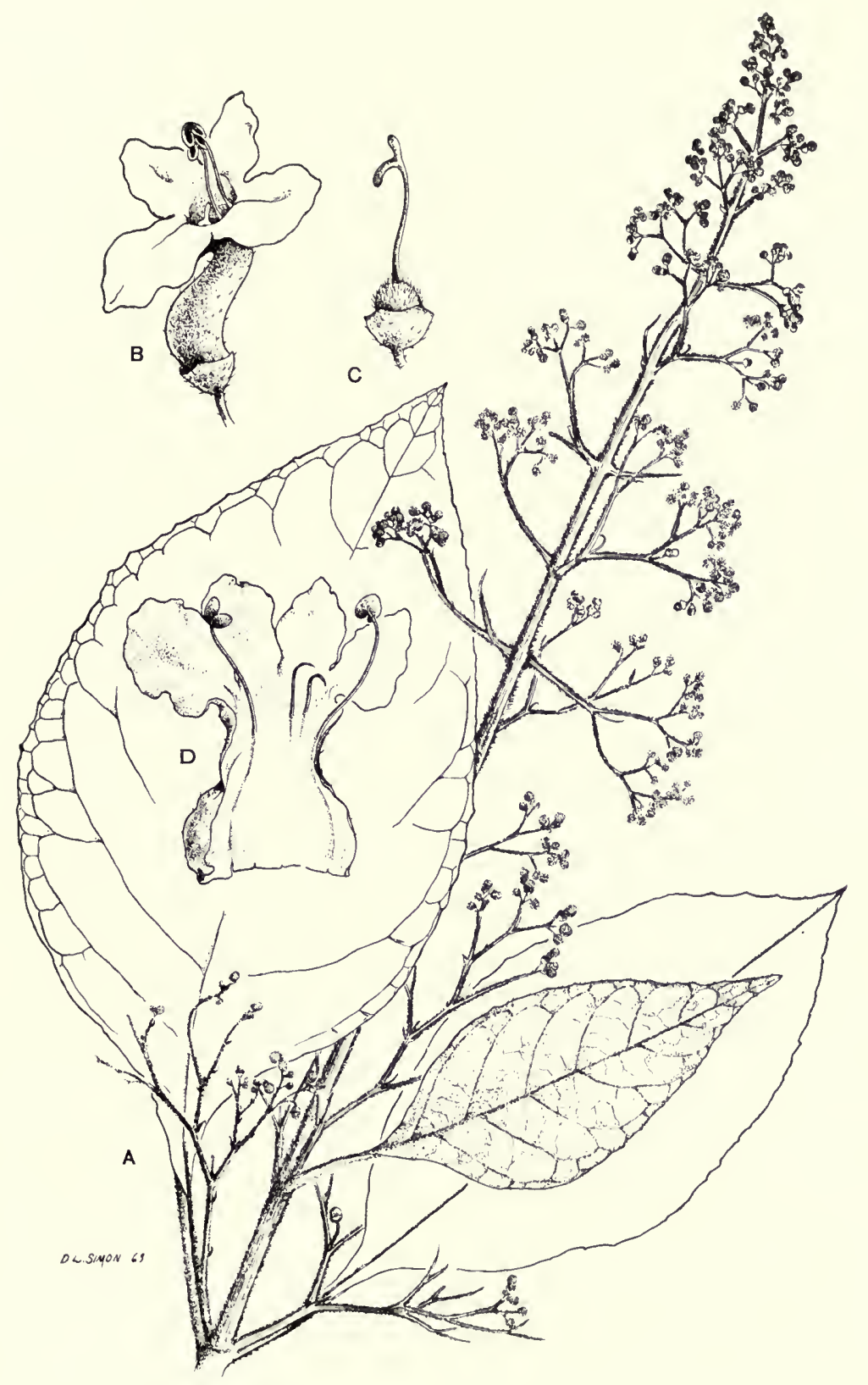

FIG. 37. Cornutia grandifolia. A, flowering branch, 1/2 natural size; B, flower, $\times 3$; C, calyx and pistil, $\times 3 ; \mathrm{D}$, corolla dissected to show stamens and staminodes, $\times 3$. 
folia f. alba Moldenke, Phytologia 2: 131. 1946. Flor lila (Guatemala); hoja de zope (Izabal); lat-che (Maya, Petén); tzultesnuk and matasano (British Honduras).

Damp forest or thickets, often in second growth, 100-1,500 meters; Alta Verapaz; Chimaltenango; Chiquimula; El Progreso; Escuintla; Guatemala; Izabal; Petén; Quezaltenango; Sacatepéquez; San Marcos; Santa Rosa; Sololá; Suchitepéquez; Zacapa. Mexico; British Honduras; El Salvador and Honduras to Nicaragua; West Indies.

Large shrubs or weak trees to $12 \mathrm{~m}$. tall, the trunk reported as sometimes $15 \mathrm{~cm}$. in diameter, the branchlets densely short-pubescent, puberulent, or tomentulose, of ten somewhat viscid; leaves on petioles $0.5-3 \mathrm{~cm}$. long, the blades elliptic, elliptic-ovate, or broadly ovate, $4-20 \mathrm{~cm}$. long, $4-14 \mathrm{~cm}$. wide, acute or acuminate, usually attenuate (rarely acute) to the base and decurrent, the margins repand. denticulate or entire, both surfaces densely short-pubescent or puberulent or the lower surface tomentulose; inflorescences terminal or subterminal, paniculate, 10$40 \mathrm{~cm}$. long, $5-10 \mathrm{~cm}$. wide, the pedicels and peduncles of the cymes densely shortpubescent or puberulent, often somewhat viscid; calyx cupuliform at anthesis, 1-3 mm. long, densely short-pubescent, truncate, sometimes obscurely toothed, in fruit patelliform to shallowly cupular; corolla blue to purple, densely short pubescent or puberulent, the tube 7-11 $\mathrm{mm}$. long, 1-2.2 mm. wide, somewhat incurved or nearly straight, the lower lip of the limb usually half as long as the abaxial side of the tube, or shorter; ovary pubescent, style short-pubescent; fruits subglobose, puberulent or pubescent, 3-6 $\mathrm{mm}$. long.

The indument of West Indian plants is albidous, while that of Central American species is usually fulvous, roseate, or purplish, but they differ in no other respect.

Although specimens determined by Moldenke to be $C$. grandifolia var. intermedia Moldenke tend to have larger leaves and smaller calyces, as in $C$. grandifolia, I have placed them in $C$. pyramidata because of their corollas. Although straight and curved corolla tubes can often be found on the same plant, they are usually straighter, narrower and much less dilated than those of $C$. grandifolia and the lower lip of the corolla is usually not more than half as long as the tube. Their indument is also shorter, as in C. pyramidata.

Because there is such a wide range of variation in both $C$. grandifolia and C. pyramidata, some forms may appear quite different. However, it is not always easy to separate even these two taxa. The fruits are identical. Considerable variation in calyx length and corolla tube width is sometimes seen on a single plant. Attempts to describe separately all the intermediate representatives of such variable plants have resulted in the creation of species and varieties separated only by inconstant and ill-defined characters. 


\section{DURANTA L.}

Shrubs or small trees, glabrous or pubescent, sometimes armed with spines, the branches of ten elongated and recurved or pendent; leaves opposite or verticillate, entire or dentate; inflorescences racemose, terminal or axillary, the flowers bracteate; calyx tubular, truncate, 5 -costate, each costa terminating in a small tooth; corolla blue, lavender, or white, salverform, the tube exserted from the calyx, the limb spreading, regular or oblique, usually pubescent within at the orifice, the lobes 5; stamens 4, didynamous, included, inserted at or above the middle of the corolla tube (occasionally a staminode present), the filaments very short; anthers sagittate, dorsifixed, the cells parallel; ovary more or less completely 8-locular, composed of 4 bilocular carpels, each locule uniovulate; style terminal, the stigma obliquely subcapitate; calyx accrescent in fruit, usually longer than and of ten enclosing the fruit; fruit drupaceous, the exocarp fleshy, the endosperm hard, nutlike; pyrenes 4 , each bilocular, each containing 2 seeds.

About 35 species, in tropical America. There are two species in Guatemala, and a third occurs in southern Central America.

Branches usually armed; branchlets, rachis, and pedicels copiously pilosulous or tomentose; calyx 5-7.5 mm. long at anthesis.

D. guatemalensis.

Branches usually unarmed; branchlets, rachis, and pedicels appressed-pubescent, appressed-puberulent, or glabrate; calyx $3.5-5 \mathrm{~mm}$. long at anthesis.

D. repens.

Duranta guatemalensis Moldenke, Bull. Torr. Bot. Club 68: 501. 1941.

Dry, brushy or wooded slopes, 1,400-2,600 meters; El Quiché (type from Chiúl, Heyde \& Lux 2947); Huehuetenango (between San Ildefonso Ixtahuacán and Cuilco). Mexico (Chiapas).

Shrubs or small trees to $4.5 \mathrm{~m}$. tall, the branchlets densely tomentose or sometimes glabrate in age, armed with stiff spines $3-15 \mathrm{~mm}$. long; leaves short-petiolate, the blades oblanceolate, obovate, or elliptic, 1.5-6 $\mathrm{cm}$. long, usually obtuse or rounded at the apex, sometimes acute, cuneate and often decurrent at the base, the margins entire or sparsely serrate near the apex, sparsely pilosulous above or in age glabrate, paler beneath, puberulent-pilosulous; racemes few-many-flowered, $3-5 \mathrm{~cm}$. long; bracts minute, 1-2 mm. long; pedicels 1-2 mm. long; calyx tubular, accrescent, minutely 5 -apiculate, $5-7.5 \mathrm{~mm}$. long at anthesis, $2-3.5 \mathrm{~mm}$. wide, pubescent outside, densely so within; corolla puberulent outside, the tube 7-9 $\mathrm{mm}$. long, ca. $3 \mathrm{~mm}$. wide, the limb $9-11 \mathrm{~mm}$. across, the lobes densely pubescent within; ovary and style glabrous; fruit yellow, subglobose, almost $1 \mathrm{~cm}$. in diameter, completely enclosed in the yellow, glabrate calyx which is prolonged by the persistent apiculum into a short, curved beak.

Duranta repens L. Sp. Pl. 637. 1753. D. plumieri Jacq. Sel. Stirp. Amer. 186.t. 176, f. 76. 1763. D. repens var. alba L. H. Bailey, Manual Cult. Pl. 843. 1949. Coralillo rosado (Guatemala). 


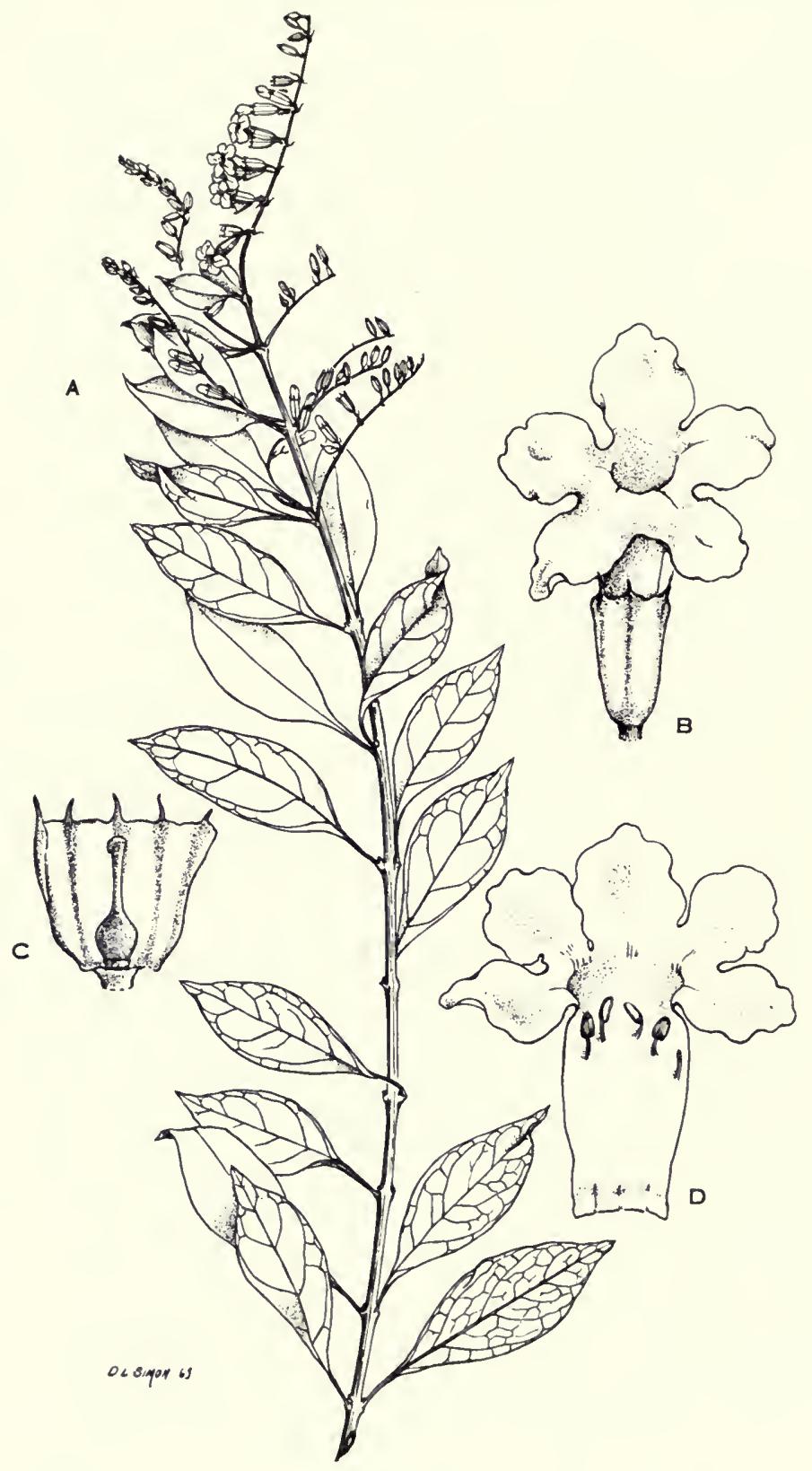

FIG. 38. Duranta repens. A, flowering branch, $1 / 2$ natural size; $B$, flower, $\times 3$; $\mathrm{C}$, calyx opened to show pistil, $\times 3 ; \mathrm{D}$, corolla dissected to show stamens and staminode, $\times 3$. 
In thickets, secondary forest, hedges, along roadsides, 500-2,600 meters; Guatemala; Quezaltenango; Santa Rosa; Sololá; Suchitepéquez. West Indies; Mexico to northern South America.

Shrubs or small trees to $6 \mathrm{~m}$. tall, usually unarmed, the branches tetragonous, commonly long and pendent, the branchlets glabrous or appressed-pubescent or puberulent; leaves short-petiolate, the blades elliptic to obovate, $2-8 \mathrm{~cm}$. long, obtuse or acute at the apex, cuneate and decurrent at the base, the margins entire or serrate above the middle, glabrous or somewhat appressed-puberulent beneath, especially on the costae and lateral veins; racemes $3-16 \mathrm{~cm}$. long, glabrous or appressed-puberulent, laxly many-flowered, of ten recurved or pendent, the bracts 2-4 mm. long and linear, or the lower ones foliaceous and of ten exceeding the calyx; pedicels $2-5 \mathrm{~mm}$. long, usually appressed-puberulent; calyx tubular, accrescent, 3.5-5 $\mathrm{mm}$. long at anthesis, 5-costate, the costae prolonged and forming apicula 0.5-1 mm. long, sparsely appressed-puberulent or glabrous outside, sericeous within; corolla puberulent or essentially glabrous outside, the tube 7-8 $\mathrm{mm}$. long, 1.5$2 \mathrm{~mm}$. wide, the limb $8-15 \mathrm{~mm}$. across, the lobes usually puberulent within; ovary and style glabrous; fruit yellow, globose, 7-12 mm. in diameter, completely enclosed in the yellow calyx which is prolonged by the persistent apiculum into a short, curved beak.

This species, which is frequent in cultivation in Guatemala, is thought by some to have been introduced into Central America. If this is true, it is certainly widely distributed and has become naturalized in a variety of places.

\section{LANTANA L.}

Erect, ascending, or scandent shrubs, the branches aculeolate or unarmed; leaves opposite or verticillate; inflorescences spicate, the spikes often short and headlike, densely flowered, the peduncles axillary, solitary or binary in the leaf axils; flowers small, bracteate; calyx small, membranaceous, truncate or irregularly sinuate-dentate; corolla white, pink, purple, yellow, or red, the tube cylindric, slender, usually more or less minutely puberulent outside, of ten somewhat pubescent within the throat, the limb with 4 or 5 lobes, the lobes obtuse or retuse; stamens 4, didynamous, included, inserted at about the middle of the corolla tube; anthers ovate, the cells parallel; ovary unicarpellate, bilocular, each locule uniovulate; style terminal, stigma thick, oblique or sublateral; ovules basal and erect or attached laterally near the base of the locule; fruit drupaceous, juicy, bilocular or splitting into 2 unilocular pyrenes, the endocarp hard; seeds without endosperm.

Perhaps 50 species, mostly in tropical America, with five in Guatemala.

Many species are separated by poor and variable differences, only a few of those found in North America being clearly differentiated.

Stems usually aculeolate; corolla yellow to orange, or red, the tube $7-10 \mathrm{~mm}$. long. 
Stems never aculeolate; corolla white, cream, pale pink, or purple, the tube $2-6 \mathrm{~mm}$. long.

Lowermost bracts of inflorescence lanceolate, acuminate to cuspidate.

Margins of leaf blades acutely serrate; leaves usually binate; peduncles of ten twice as long as the leaves.................. achyranthifolia.

Margins of leaf blades crenate-serrate; leaves usually ternate; peduncles of ten equalling or exceeding the leaves but not twice as long. ....L. trifolia.

Lowermost bracts of inflorescence ovate, broadly ovate, or oblong-elliptic, acute or obtuse.

Leaf blades subacute to acuminate at apex, margins crenate, indument composed of erect or ascending hairs; lowermost bracts of inflorescence ovate to broadly ovate........................ hispida.

Leaf blades rounded at apex, margins closely crenulate, indument composed of appressed hairs; lowermost bracts of inflorescence lanceolate to oblongelliptic.................................. involucrata.

Lantana achyranthifolia Desf. Cat. Pl. Paris ed. 3. 392. 1829. L. purpurea Benth. \& Hook. f. Gen. Pl. 2: 1142. 1876. L. macropodioides Greenm. Field Mus. Bot. 2: 339. 1912.

Damp or dry thickets, 500-800 meters; Huehuetenango. Mexico; Honduras.

Erect, unarmed shrubs to $1.5 \mathrm{~m}$. tall, the stems appressed-strigose; leaves lanceolate to broadly ovate, short-petiolate, the blades $4-8 \mathrm{~cm}$. long, acuminate to long-acuminate, obtuse or acute at the base and of ten abruptly decurrent, acutely serrate, strigose on both surfaces, pale beneath; inflorescence pedunculate, capitate, the peduncles stiff, straight, much longer than the leaves and of ten twice as long or more, the flower heads short at anthesis but elongating in age, of ten becoming much longer than broad, in fruit sometimes $2.5 \mathrm{~cm}$. long, $1.5 \mathrm{~cm}$. in diameter; bracts lance-ovate or lanceolate, acuminate, pale green, densely hispidulous or strigose, the lowermost ones sometimes to $12 \mathrm{~mm}$. long; corolla usually white but may be purplish, the tube $3-4 \mathrm{~mm}$. long, puberulent.

This is often confused with the Mexican L. macropoda Torrey, which has smaller, less sharply serrate leaves, acute at the apex.

Lantana camara L. Sp. Pl. 627. 1753. L. aculeata L. loc. cit. L. mista L. Syst. ed. XII, 2: 417. 1767. L. horrida HBK. Nova Gen. \& Sp. 2: 261. 1817. L. tiliaefolia Cham. \& Schlecht. Linnaea 7: 122. 1832. L. hirsuta Mart. \& Gal. Bull. Acad. Brux. 11: 326. 1844. L. horrida var. grandiflora Schauer in DC. Prodr. 11: 598. 1847. L. horrida var. parviflora Schauer in DC. loc. cit. L. camara var. crocea Bailey, Cycl. Am. Hort. 884. 1900. L. camara var. mista (L.) Bailey, loc. cit. L. glandulosissima Hayek in Fedde, Rep. Sp. Nov. 2: 161. 1906. L. crocea var. guatemalensis Loes. Verh. Bot. Ver. Brandenb. 53: 76. 1911 (type from Huehuetenango, Seler 2805). L. camara var. macrantha Loes. loc. cit. L. camara var. aculeata (L.) Moldenke, Torreya 34:9. 1934. L. scorta Moldenke, Carnegie Inst. Wash. Pub. 


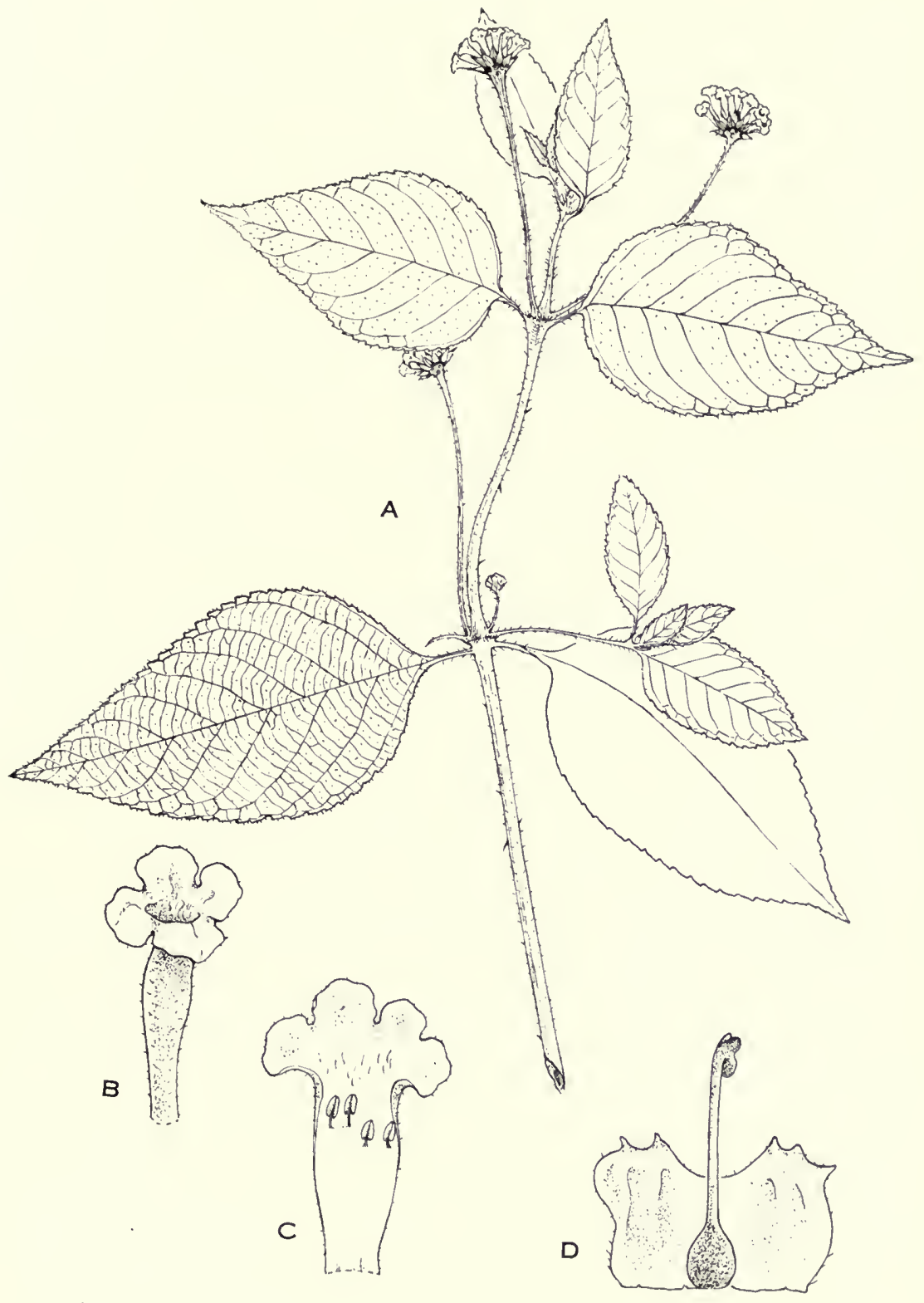

D.L. SHOH is

FIG. 39. Lantana camara. A, flowering branch, $1 / 2$ natural size; B, corolla, $\times 3$; C, corolla dissected to show stamens, $\times 3 ; \mathrm{D}$, calyx opened to show pistil, $\times 10$. 
522. 161. 1940. L. scandens Moldenke, Phytologia 2: 18. 1941. L. hispida var. ternata Moldenke, Phytologia 2: 225. 1947. L. camara var. parvifolia Moldenke, Phytologia 2: 467. 1948. L. hirta f. ternata Moldenke, Phytologia 8:160. 1962. Chiligua nigrita (Jalapa); cinco negritos (Guatemala, Retalhuleu, Sacatepéquez); ek-cuaiyak (Alta Verapaz); mora de muerto (Alta Verapaz); sincuria (Izabal); vivarana (Guatemala).

Common in wet to dry thickets or open forest, sometimes in pine forest, abundant in second growth, frequently on limestone, a weed of banana plantations, of ten invading cultivated ground, sea level to 2,200 meters; Alta Verapaz; Baja Verapaz; Chimaltenango; Escuintla; Guatemala; Huehuetenango; Izabal; Jalapa; Petén; Quezaltenango; Retalhuleu; Sacatepéquez; San Marcos; Santa Rosa; Sololá; Zacapa. Southern Florida; Mexico; British Honduras to El Salvador and Panama. West Indies and South America; naturalized in the Old World tropics.

Shrubs, usually 1-3 m. tall, of ten subscandent, the stems then attaining greater lengths, stems usually aculeolate, rarely unarmed, pilose or hirsute with glandtipped or eglandular hairs; leaves opposite, binate or rarely ternate, petiolate, broadly ovate to oblong-ovate, $2-12 \mathrm{~cm}$. long, the margins crenate-serrate, the apex acute or short-acuminate, acute or rounded at the base and abruptly decurrent or cordate; of ten bullate or rugose, scabrous to scabrous-tomentose above, variously pubescent beneath (densely viscid-tomentose to strigose or rarely glabrate); inflorescences densely flowered heads, the peduncles $2-14 \mathrm{~cm}$. long, the bracts linear, linear-lanceolate, lanceolate, or lanceolate-oblong (rarely spatulate), usually shorter than the corolla tube; calyx ca. $3 \mathrm{~mm}$. long; corolla usually yellow to orange, fading to red, sometimes red from the first, the tube $7-10 \mathrm{~mm}$. long, the limb 2-6 mm. broad (sometimes larger in cultivated specimens); drupes few, blue to black at maturity, lustrous, juicy.

This is a common, weedy shrub in much of tropical America. It is often grown in gardens of temperate America where it is a popular bedding plant. The heads of ripe black fruits often resemble blackberries. Although of poor flavor, they are eaten by children and are sought by birds.

The material here referred to $L$. camara is divided by Moldenke and others into several species but the characters on which the supposed "species" are based are variable and inconstant.

Called "wild sage" in British Honduras.

Lantana hispida HBK. Nova Gen. \& Sp. 2: 260. 1817. L. hirta R. Grah. Edinb. Phil. Journ. 186. 1826. L. velutina Mart. \& Gal. Bull. Acad. Brux. 11, pt. 2: 325. 1844. L. involucrata var. velutina 
Standl., Field Mus. Bot. 11: 172. 1936. L. frutilla Moldenke, Phytologia 1:419. 1940. L. velutina f. violacea Moldenke, l.c. 8: 161. 1962. L. hispida f. alba Moldenke, l.c. 9: 99. 1963. L. frutilla var. obtusifolia Moldenke, l.c. 14: 217. 1967. Chiligua (Jutiapa); chinkuro (Jalapa); corronchocho (Chimaltenango, Guatemala); morita negra and oregano del monte (Guatemala).

Damp forest or thickets, sometimes in oak, pine-oak, or pine forest, occasionally on dry, rocky hillsides, 300-2,700 meters; Alta Verapaz; Baja Verapaz; Chimaltenango; Chiquimula; Escuintla; Guatemala; Huehuetenango; Izabal; Jalapa; Jutiapa; Quezaltenango; El Quiché; Sacatepéquez; San Marcos; Sololá; Zacapa. Mexico to Panama.

Erect, unarmed shrubs, 1-2 m. tall, the branches puberulent to hispidulous; leaves usually opposite, rarely verticillate, usually short-petiolate, rarely subsessile, the blades rugose, broadly ovate to lance-ovate, oblong-lanceolate, or ovateoblong, 1-9 cm. long (mostly $2-5 \mathrm{~cm}$.), subacute to acuminate, acute or cuneate at the base or broad and abruptly contracted, decurrent, usually scabrous above, rarely merely puberulent or pilosulous, glandular-pellucid beneath and thinly hispidulous along the nerves to densely tomentulose or velutinous-pilosulous; margins crenate (usually 18-30 indentations on each side); inflorescence headlike, pedunculate; bracts lance-ovate to broadly ovate, acute, usually as long as the corolla tube or longer, the lowermost ones broadest, sometimes foliaceous, of ten venose; corolla white, cream-colored, pale pink, or purplish, of ten with a yellow throat, the tube 4-6 $\mathrm{mm}$. long; fruits purple black, juicy.

The two most diverse forms of this complex species are those plants with oblong-lanceolate, finely crenate, scabrous to hispidulous leaves (1,300-2,700 meters) and those with broadly ovate, coarsely crenate, always velutinous-tomentulose leaves (600-1,900 meters), and the temptation to retain $L$. velutina as a repository for all plants in the latter category is understandable. However, one would then be confronted with the problem of where to place the numerous intermediate forms with various combinations of leaf shape, margin, and indument that occur throughout the range (300-2,700 meters). A photograph of the type specimen of L. hispida (Field Museum Neg. No. 39493) clearly shows the lower leaf surface to have been fairly tomentose rather than merely hispidulous, and, in fact, is almost identical with some specimens which have previously been identified as L. velutina.

The indument of stems and lower leaf surfaces of a single Guatemalan collection which was reported as $L$. microcephala A. Rich., Watson 458c, is not strigose-canescent but is composed of ascending hairs. Only in the shape of the leaves is it like L. microcephala (which may prove to be synonymous with $L$. canescens HBK.). 
Lantana involucrata L. Cent. Pl. 2: 22. 1756; Amoen. Acad. 4: 319. 1759. L. odorata L. Syst. ed. XII, 2: 418. 1767. L. odorata var. berlandieri Torrey, U. S. \& Mex. Bound. Survey (Bot.) 128. 1858. L. involucrata var. odorata (L.) Moldenke, Phytologia 2: 53. 1941.

Open places, margins of thickets, chiefly along sea beaches; frequently invading coconut plantations; southern Florida; Mexico; British Honduras; West Indies; northern South America.

Erect, unarmed shrubs to $1.5 \mathrm{~m}$. tall, the branches strigose; leaves on petioles 2-10 mm. long, the blades ovate, oblong-ovate or oblong-elliptic to obpyriforme, $2.5-7 \mathrm{~cm}$. long in ours, the apex obtuse or rounded, acute at base or contracted and decurrent, the margins very finely and closely crenulate, rugose and scabrous above, usually strigillose but sometimes glabrate beneath; inflorescences globose, usually densely flowered, long-pedunculate, the bracts oblong to elliptic, strigillose, the lowermost ones 8-11 mm. long; corolla usually pink, lilac, or purple, sometimes white, the tube puberulous, $2-4 \mathrm{~mm}$. long; drupes $2-3 \mathrm{~mm}$. long, blue or purple.

These plants are very aromatic.

Lantana trifolia L. Sp. Pl. 626. 1753. L. trifolia var. geminata Loes. Verh. Bot. Ver. Brandenb. 53: 75. 1911. Comida de paloma (Izabal).

Usually in damp thickets, sometimes in low pine forest, rarely in cleared land, near sea level to 1,200 meters; Alta Verapaz; Guatemala; Izabal (type from Los Amates, Seler \& Seler 3378); Petén; El Quiché. Mexico; British Honduras to El Salvador and Panama. West Indies; South America.

Erect, unarmed shrubs, to $3 \mathrm{~m}$. tall, the stems rather harshly pilose; leaves usually ternate, sometimes binate, short petiolate, the blades lanceolate, oblong. lanceolate, elliptic-lanceolate, or occasionally ovate, 4-14 cm. long, acute or acuminate, acute or attenuate to the base, crenate serrate, scabrous or strigose above, puberulent or pilosulous beneath, resinous-punctate; inflorescences at first headlike, in age elongated and spikelike, sometimes $5 \mathrm{~cm}$. long, densely flowered, pedunculate, the peduncles 1 or 2 in each leaf axil, shorter than, equalling, or longer than the leaves; bracts green, lanceolate or ovate, cuspidate; corolla usually pink, lilac, or purple, rarely white, the tube puberulent, 4-6 mm. long; drupes lilac or purple, juicy.

A common, weedy plant in many parts of the Central American lowlands, often seen in second growth.

\section{LIPPIA Houst. ex L.}

Herbs, shrubs, or small trees, often aromatic, glabrous or pubescent; leaves opposite or ternate, entire or dentate; inflorescences usually pedunculate, the pe- 
duncles solitary to several in the leaf axils, spicate, the spikes short and nearly globose or elongated and cylindrical, dense and many-flowered, the bracts generally conspicuous; calyx small, membranaceous, ovoid-campanulate or compressed and bicarinate; corolla tube cylindrical, straight or incurved, the limb oblique, spreading, somewhat bilabiate, the lobes 4 ; stamens 4 , didynamous, inserted near the middle of the corolla tube, included or only slightly exserted; anthers ovate, not appendaged in ours, the cells parallel; ovary bilocular, 1 ovule in each locule; style terminal, stigma obscurely bilobate, oblique or recurved; ovules basal and erect or affixed laterally near the base; fruit small, dry, included in the persistent calyx, at maturity separating into 2 pyrenes; pericarp hard and dry; seeds without endosperm.

A few herbaceous species of this genus have been treated by Moldenke and some earlier workers as constituting a distinct genus, Phyla, but I prefer to leave them, as most authorities have, in Lippia.

Nearly 200 species have been reported, the majority of them from tropical America. Additional studies may result in the reduction of a considerable number of them to synonymy. Only 13 are known from Guatemala.

Plants herbaceous to suffruticose, of ten prostrate or procumbent; flower heads elongating in fruit; bracts cuneate-obovate to rhombic.

Peduncles much shorter than the flower heads, usually 2 or more in each leaf

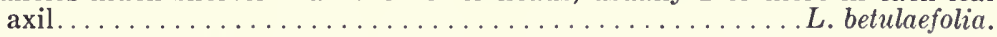

Peduncles much longer than the flower heads, solitary in each leaf axil.

Leaf blades ovate or rhombic-ovate.

Hairs of leaf surface minutely bulbous-based, never malpighiaceous; calyx completely villous. ......................... dulcis.

Hairs of leaf surface malpighiaceous; calyx with a fine line of hairs on each keel............................... reptans.

Leaf blades linear-oblong, cuneate-oblong, spatulate, or cuneate-obovate.

Leaf blades linear-oblong; coarsely dentate along the whole margin; 10 18 pairs of lateral veins, these prominent......... stoechadifolia.

Leaf blades spatulate to cuneate-obovate, usually dentate only above the middle; the 5-6 pairs of lateral veins more or less obsolete.

L. nodiflora.

Plants erect shrubs or small trees; flower heads usually not or scarcely elongating in fruit (except $L$. alba); bracts ovate or lanceolate.

Peduncles normally solitary in each leaf axil. . . . . . . . . . . . . . . . L. alba.

Peduncles normally 2 or more in each leaf axil.

Bracts of the inflorescence conspicuously 4-ranked; leaf blades uniformly small, mostly $2-4 \mathrm{~cm}$. long.................. graveolens.

Bracts of the inflorescence not evidently 4-ranked; leaf blades variable in size, at least some of them more than $4 \mathrm{~cm}$. long.

Leaves densely and softly tomentose or pilose beneath.

Flower heads at anthesis $5 \mathbf{5} \mathbf{9 m}$. in diameter.

Corolla yellow, twice as long as the calyx............ chiapasensis.

Corolla white, scarcely exceeding the calyx........... salamensis.

Flower heads at anthesis $10-16 \mathrm{~mm}$. in diameter........L. substrigosa.

Leaves glabrate beneath, strigose, thinly hispidulous, or scabrous. 
Leaves smooth to the touch, the margins entire or obscurely crenate or serrulate............................ myriocephala.

Leaves rough to the touch, the margins conspicuously crenate, dentate, or serrate.

Flower heads small $(4-8 \mathrm{~mm}$. in diameter at anthesis, in fruit 7-10 $\mathrm{mm}$. in diameter); lowermost bracts $3-8 \mathrm{~mm}$. long . . . . . L. cardiostegia.

Flower heads large $(8-15 \mathrm{~mm}$. in diameter at anthesis, in fruit to 25 $\mathrm{mm}$.); lowermost bracts $10-15 \mathrm{~mm}$. long. . . . . . . L. controversa.

Lippia alba (Mill.) N. E. Browne ex Britton \& Wilson. Fl. Porto Rico 6: 141. 1925. Lantana alba Mill. Gard. Dict. ed. 8, no. 8. 1768. Lippia geminata HBK. Nova Gen. \& Sp. 2: 266. 1818. Orozuz; salvia santa; salvia siga (Alta Verapaz and Guatemala).

Usually on brushy hillsides and along roadsides (where it may have escaped from cultivation), sometimes on riverbanks and sandbars, sea level to 1,800 meters; Alta Verapaz; Chiquimula; Escuintla; Guatemala; Huehuetenango; Sacatepéquez; Sololá. Texas; Mexico; British Honduras to Panama; West Indies; South America.

Shrubs to $2 \mathrm{~m}$. tall, usually sparsely branched, rather densely puberulent to strigose; leaves opposite or sometimes ternate, the petioles 2-10 (14) mm. long, the blades 2-7 cm. long, oblong, lance-oblong, or ovate-oblong, acute or obtuse, cuneate or attenuate to the base and decurrent on the petiole, strigose-hirtellous or puberulent, sometimes canescent, the margins finely serrate; peduncles usually solitary (rarely geminate) in the leaf axils; flower spikes first subglobose, ca. $6 \mathrm{~mm}$. long, usually elongating to 8-12 $\mathrm{mm}$. long; bracts puberulous, ovate, abruptly acuminate, the lower ones sometimes mucronate, $3-5 \mathrm{~mm}$. long; calyx villous, 1.5-2 mm. long; corolla pale lilac, purple, or white with purple, 5-6 mm. long.

Grown frequently in gardens throughout Central America as a medicinal plant, a tea made from the leaves being a favorite domestic remedy for both intestinal and respiratory disturbances.

Lippia betulaefolia HBK. Nova Gen. \& Sp. 2: 264. 1818. Phyla betulaefolia Greene, Pittonia 4: 48. 1899.

Open, wet fields or swamps, sea level to 225 meters; Escuintla: Izabal. British Honduras to Panama; West Indies; South America.

Plants annual or perennial, erect or decumbent, of ten rooting at the nodes, the stems strigillose; leaves on petioles $0.5-2.5 \mathrm{~cm}$. long, the blades ovate or rhombicovate, $1.5-6.5 \mathrm{~cm}$. long, acute or obtuse, cuneate and decurrent at the base, coarsely dentate, densely or sparsely strigose with largely malpighiaceous hairs; peduncles short, 1-4 mm. long, 2-6 or more at each node; flower spikes oblong, $0.5-2 \mathrm{~cm}$. long; bracts of the inflorescence cuneate, cuspidate; caly $\mathrm{x}$ minute; corollas greenish or pinkish, to $1 \mathrm{~mm}$. long.

Lippia cardiostegia Benth. Voy. Sulphur 153. 1844. L. lucens Standl. Trop Woods 37: 30. 1934. L. brenesii Standl. Field Mus. 
Bot. 18: 1009. 1938. L. hypoleia var. ovatifolia Moldenke, Phytologia 14: 217. 1967. Vara fina (Guatemala); chiliqua (Jutiapa); coronchoch (Huehuetenango).

Damp or dry, often rocky, brushy plains and hillsides, sometimes in open, mixed forest, 150-1,500 meters; Alta Verapaz; Chimaltenango; Chiquimula; Escuintla; Guatemala; Huehuetenango; Jutiapa; El Quiché; Sacatepéquez; Santa Rosa. Southern Mexico; El Salvador; Honduras; Nicaragua; Costa Rica.

Shrubs to $3 \mathrm{~m}$. tall, the branches strigose or scabrous; leaves petiolate, the blades lanceolate, oblong-ovate to ovate or elliptic-oblong, usually $2-7 \mathrm{~cm}$. long, 1-3 cm. wide (rarely to $12 \mathrm{~cm}$. long, $4-5 \mathrm{~cm}$. wide), 5-7 pairs of lateral veins, acute or subobtuse at apex, cuneate-attenuate to the base, the margins crenate to serrate, upper surface bullate-rugose, usually hirtellous-scabrous, harsh to the touch, of ten lustrous, usually glabrate beneath but somewhat hirtellous-scabrous on the veins; peduncles 2-several in leaf axils, equalling or shorter than the leaves, usually 1.5$3 \mathrm{~cm}$. long (rarely 4-5 cm. long); flowering spikes nearly globose, variable in size, most often 8-12 $\mathrm{mm}$. long; bracts ovate to rounded-ovate, sometimes cordate, acute, acuminate, or apiculate, puberulent, scabrous, or nearly glabrous, minutely ciliate, the outer ones $3-8 \mathrm{~mm}$. long; calyx $1-2 \mathrm{~mm}$. long, usually densely hirtellous; corolla $2-3 \mathrm{~mm}$. long, pale greenish yellow or greenish white, puberulent, often glandular below lobes.

This species is extremely variable, especially in leaf size and length of peduncles, but there seem to be no definitive characters by which the various forms can be separated. One specimen, Steyermark 31596 , is atypical because of its relatively narrow, oblanceolate to ellipticoblong leaves.

Several collections from Honduras of L. oxyphyllaria (Donn.Sm.) Standley (once thought to be endemic to Costa Rica and Panama) have been misidentified and distributed in herbaria as L. lucens. Those which I have seen, Williams and Molina R. 10802, Molina R. 1456, 1837 and 3213, and Standley 26473 were also incorrectly cited by Moldenke. Although the leaves of L. oxyphyllaria are bullate-rugose and sometimes glabrate and lustrous, they are usually more or less pilose; the flower heads are much larger than those of $L$. cardiostegia, often $2.5 \mathrm{~cm}$. wide, and in fruit $3-4 \mathrm{~cm}$. long, with large bracts, sometimes as long as $1.8 \mathrm{~cm}$.

Lippia chiapasensis Loes. Verh. Bot. Ver. Brandenb. 53: 78. 1911. L. curtisiana Moldenke, Phytologia 1: 425. 1940.

Wet or dry, of ten rocky thickets or forests, frequently in pine-oak forest, sometimes in meadows, 1,500-3,000 meters; Baja Verapaz; Huehuetenango; San Marcos; Sololá; Totonicapán. Mexico. 
Shrubs or weak trees to $4 \mathrm{~m}$. tall, the branches densely pubescent, leaves on petioles 4-14 mm. long, the blades ovate or ovate-elliptic, 2-6(9) cm. long, 1.5$4.5 \mathrm{~cm}$. wide, usually acute, sometimes obtuse, usually cuneate (rarely rounded) at the base, bullate and scabrous above, usually densely and softly pubescent beneath, venation prominent, margins crenate to serrate; peduncles $2-4$ in each axil, densely pubescent, $1.5-2.5 \mathrm{~cm}$. long, the flower spikes $8-9 \mathrm{~mm}$. wide, in fruit to $13 \mathrm{~mm}$. broad, dense and many-flowered; bracts ovate at anthesis, $4-5 \mathrm{~mm}$. long, 3-6 mm. wide, reniform in age, 6-9 $\mathrm{mm}$. wide, venose, puberulent to strigillose, ciliate; calyx 2-3 mm. long, hirsute; corolla yellow, twice as long as the calyx, usually puberulous at apex and within throat.

Although this plant has smaller flowering heads and generally smaller leaves than L. substrigosa Turcz., they appear to be closely related.

Lippia controversa Moldenke, Phytologia 1:423.1940. L. pinetorum Moldenke, Phytologia 2: 20. 1941. L. controversa var. brevipedunculata Moldenke, Phytologia 4: 56. 1952.

Damp or dry, brushy fields or hillsides, 500-1,400 meters; Escuintla; Jutiapa; Sacatepéquez; Santa Rosa. Mexico; Honduras.

Shrubs to $2 \mathrm{~m}$. tall, the branches hispidulous or glabrate; leaves short-petiolate, the blades broadly ovate or ovate-elliptic, mostly $4-9 \mathrm{~cm}$. long, acute, of ten abruptly so, usually rounded or obtuse at the base and abruptly long-decurrent, very rough to the touch, hispidulous above with bulbous-based hairs, sparsely hispidulous beneath, especially on the veins, rugose, the margins crenate or dentate; peduncles 1-2 in each leaf axil, 2-4 cm. long, slender, glandular-pubescent; bracts usually ovate, sometimes nearly lanceolate, acute, the lowest $1-1.5 \mathrm{~cm}$. long, venose, strigillose to puberulent; the spikes in fruit sometimes $2.5 \mathrm{~cm}$. broad; calyx ca. $2 \mathrm{~mm}$. long at anthesis, to $3 \mathrm{~mm}$. in fruit, villous; corolla 4-6 mm. long, puberulent, cream-colored, yellow, or greenish-yellow.

Sometimes confused with L. oxyphyllaria (Donn.-Sm.) Standley, with which it is probably closely related.

Lippia dulcis Trev. Nov. Act. Acad. Caes. 13, pt. 1:187. 1826. Zapania scaberrima Juss. ex Pers. Syn. Pl. 2: 140. 1806, not Lippia scaberrima Sond. 1850. Phyla dulcis Moldenke, Torreya 34: 9. 1934. Phyla scaberrima Moldenke in Fedde, Rep. Sp. Nov. 41:64. 1936. Orozuz (Alta Verapaz).

Damp thickets and waste ground, wooded river banks, borders of ponds, or in open clearings and pastures, sea level to 1,800 meters; Alta Verapaz; Chiquimula; Guatemala; Petén; Retalhuleu; Sacatepéquez; Santa Rosa; Sololá. Southern Mexico; British Honduras to Panama; West Indies. 
Perennial plants, erect or decumbent, rarely to $40 \mathrm{~cm}$. tall, usually more or less fruticose near the base, strong-scented, the stems of ten rooting at the lower nodes, strigillose or glabrate; leaves on petioles $0.5-1.5 \mathrm{~cm}$. long, the blades rhombic to ovate, 1-6 $\mathrm{cm}$. long, acute to somewhat acuminate, broadly cuneate at the base, the margins crenate-serrate, upper surface strigose, rough to the touch, sparsely to densely strigillose beneath and obscurely glandular; peduncles solitary in the leaf axils, 1-5 cm. long; flower spikes ovoid.globose at first, later cylindric, ca. $6 \mathrm{~mm}$. thick, the heads occasionally elongating to as much as $3 \mathrm{~cm}$. long in age but usually shorter; bracts cuneate-obovate, obtuse and abruptly acuminate; calyx minute, villous; corolla white, $1-1.5 \mathrm{~mm}$. long.

Lippia dulcis is one of the group of Lippias which some workers hold to belong to the separate genus Phyla, but does not have malpighiaceous hairs.

This plant is said to be much used in domestic medicine. The leaves are aromatic; the root when chewed has the flavor of licorice, hence the name "Orozuz," common in Central America.

Lippia graveolens HBK. Nova Gen. \& Sp. 2:266. 1818. Lantana origanoides Mart. \& Gal. Bull. Acad. Brux. 11(2): 327. 1844. Lippia berlandieri Schauer in DC. Prodr. 11: 575. 1847. Goniostachyum graveolens Small, Fl. Southeast. U. S. 1012. 1903. Orégano.

Rocky slopes or damp thickets on plains, 350 meters or less; Petén; Zacapa. Southern Texas; Mexico; Nicaragua.

Slender shrubs to $2 \mathrm{~m}$. tall, the branches short-pilose; leaves on petioles usually $5-10 \mathrm{~mm}$. long, the blades oblong to elliptic or ovate to ovate-oblong, $2-4 \mathrm{~cm}$. long, usually obtuse or rounded at the apex, sometimes acute, rounded or subcordate at the base, densely soft-pilosulous above, soft to the touch, glandular and densely tomentose or pilosulous beneath, the margins finely crenate; peduncles 2-6 in leaf axils, 4-12 mm. long; flower spikes subglobose to oblong, 4-12 mm. long; bracts 4-ranked, ovate to lanceolate, acute, glandular and densely pilosulous; calyx 1$2 \mathrm{~mm}$. long, glandular and villous; corolla white, the tube strigollose, 3-6 $\mathrm{mm}$. long.

The aromatic leaves, either fresh or dried, are used in Central America for flavoring food, and the dry leaves are often sold in the markets.

Lippia myriocephala Schlecht. \& Cham. Linnaea 5: 98. 1830. L. hypoleia Briq. Ann. Cons. Jard. Bot. Geneve 4: 236. 1900. L. myriocephala var. integrifolia Loes. Verh. Bot. Ver. Brandenb. 53: 77. 1911 (type from Cobán, Alta Verapaz, Seler 2485). L. hypoleia var. ovatifolia Moldenke, Phytologia 14:217. 1967. Cutujume (Izabal); sacatzum (Alta Verapaz).

Wet or dry, often rocky thickets, open hillsides, outer slopes of cloud forest, often in pine-oak forest, 300-2,700 meters; Alta Vera- 
paz; Baja Verapaz; Chimaltenango; Chiquimula; Guatemala; Izabal; Petén; El Progreso; Quezaltenango; Sacatepéquez; San Marcos; Santa Rosa. Mexico; British Honduras; Honduras to Costa Rica.

Shrubs or trees to $12 \mathrm{~m}$. tall, younger branches pilose with appressed or spreading hairs; leaves on petioles $3-14 \mathrm{~mm}$. long, the blades lance oblong to narrowly elliptic-oblong, oblong-ovate or (rarely) ovate, mostly $5-15 \mathrm{~cm}$. long, $1-5 \mathrm{~cm}$. wide, usually acuminate to long-acuminate, cuneate-attenuate to the base, thinly appressed-pilosulous above or glabrate, not rough to the touch, sparsely pilosulous beneath with spreading or appressed hairs to almost glabrous, the margins obscurely crenulate or serrulate or entire; peduncles $3-10$ in each axil, 1-4 cm. long, the densely flowered spikes small, only 5-6(7) $\mathrm{mm}$. long and broad, in fruit 8$9 \mathrm{~mm}$. long; bracts broadly ovate to subreniform, abruptly acute or short acuminate, puberulent and ciliate, the lower ones $2-3 \mathrm{~mm}$. long; calyx villous, ca. $1 \mathrm{~mm}$. long; corolla white or cream, sometimes tinged with lavender, the tube $0.5-1 \mathrm{~mm}$. long.

The wood is said to be used for rafters and poles in the poorer dwellings in warmer regions.

Lippia nodiflora (L.) Michx. Fl. Bor. Amer. 2: 15. 1803. Verbena nodiflora L. Sp. Pl. 20. 1753. Phyla nodiflora Greene, Pittonia 4: 46. 1899. P. incisa Small, Fl. Southeast. U. S. 1012. 1903. P. nodiflora var. longifolia Moldenke, Phytologia 2: 22. 1941.

In damp soil, usually in open places, often on sandbars, salt flats, beaches, wet meadows, and irrigation ditches, sea level to 1,400 meters; Chiquimula; Esquintla; Guatemala; Huehuetenango; Izabal ; Jutiapa; Petén; Retalhuleu; Zacapa. United States and Mexico; British Honduras to El Salvador and Panama; West Indies; South America; Old World.

Plants herbaceous, creeping and often forming large mats or colonies, the stems strigillose or glabrate; leaves short-petiolate, of ten succulent, the blades spatulate, oblanceolate, or cuneate-obovate, mostly 1-4 cm. long, rounded or obtuse at the apex, cuneate at the base, dentate above the middle, strigillose with malpighiaceous hairs or almost glabrous, peduncles solitary in the axils, usually longer than the leaves; flower spikes at first globose, elongating and becoming cylindric in age, 1-2 cm. long, 6-9 mm. thick in fruit; bracts purplish, closely imbricate, cuneateobovate to rhombic, abruptly acuminate, the lower ones of ten cuspidate; calyx bicarinate, with a line of very fine hairs along each keel; corolla white or purplish, 3-4 mm. long.

Lippia reptans (Spreng.) HBK. Nova Gen. \& Sp. 2: 263. 1818. Zapania reptans Spreng. Pl. Pugill. 2: 70. 1813. Lippia repens Spreng. Syst. 2: 752. 1825. L. strigulosa Mart. \& Gal. Bull. Acad. Brux. 11(2): 319. 1844. L. nodiflora var. reptans O. Ktze. Rev. Gen. 2: 508. 1891. Phyla reptans Greene, Pittonia 4: 47. 1899. P. nodi- 
flora var. reptans Moldenke, Torreya 34:9. 1934. P. yucatana Moldenke, Phytologia 2:140. 1946. P. yucatana var. parviflora Moldenke, Phytologia 2: 141. 1946. P. strigulosa Moldenke, l.c. 233. 1947. P. strigulosa var. parviflora Moldenke, l.c.

Usually in wet, open places, of ten bordering lakes or streams, near sea level to 1,500 meters; Alta Verapaz; Escuintla; Huehuetenango; Izabal; Jutiapa; Petén; Sacatepéquez. Mexico; British Honduras; Honduras; El Salvador; Nicaragua; Costa Rica; northern South America.

Plants herbaceous, usually prostrate and rooting at the nodes, strigillose throughout with largely malpighiaceous hairs; leaves on petioles $2-12 \mathrm{~mm}$. long, the blades rhombic to broadly ovate, $1-5 \mathrm{~cm}$. long, obtuse or acute, broadly cuneate at the base, coarsely and sharply dentate, usually 6-9 pairs of lateral veins, these conspicuous beneath; peduncles solitary in the leaf axils, longer than the leaves, sometimes to $10 \mathrm{~cm}$. long, the flower spikes subglobose to oblong, usually $1 \mathrm{~cm}$. long or less, rarely to $2 \mathrm{~cm}$.; bracts of ten purplish, cuneate-obovate to rhombic, abruptly acuminate, the lower ones sometimes cuspidate; calyx bicarinate with a line of very fine hairs along each keel, $2-2.5 \mathrm{~mm}$. long, corolla white or tinged with purple, or with a purplish throat, ca. $3 \mathrm{~mm}$. long.

Lippia salamensis Loes. Verh. Bot. Ver. Brandenb. 53:77. 1911.

Damp or dry, open hillsides or in oak forest, about 1,600 meters; Baja Verapaz (type from Cuesta Choacuz, Seler 2483 and 3404); collected also in the mountains near Morazán; Jalapa (Chahuite, northwest of Jalapa).

Slender shrubs about $2 \mathrm{~m}$. tall, the branches densely pilose with short appressed hairs; leaves thick, short-petiolate, the blades ovate to ovate-oblong or oblong, (2) 4-10 cm. long, rounded or acute at the apex, acute and decurrent to the base, the margins crenate-serrulate, upper surface somewhat rugose and short-strigose or sericeous-strigose, densely pubescent to velutinous-tomentose beneath with short, more or less spreading, soft hairs; peduncles several in each axil, usually about 5, commonly 1-2 cm. long, slender, appressed-pilosulous; flower spikes subglobose to ovoid, in anthesis $5-7 \mathrm{~mm}$. long and $7 \mathrm{~mm}$. broad, in fruit elongating to $10 \mathrm{~mm}$. long; bracts thin, reticulate-veined, pubescent or hirtellous, ciliolate, broadly ovate to cordate-reniform; calyx 2-2.4 mm. long, hirtellous; corolla white, scarcely longer than the calyx, puberulent.

This closely resembles a fragment of the type of $L$. jurgensenii Briq. from Oaxaca, Mexico (Ann. Conserv. Jard. Bot. Genève 4: 239. 1900). The description is very similar except for the shorter calyx of the Mexican plant. If they should prove to be synonymous, as seems likely, then $L$. jurgensenii would, of course, take precedence. Because of inadequate material, it is probably best to maintain them separately for the present. 
Lippia stoechadifolia (L.) HBK. Nova Gen. \& Sp. 2:265. 1818. Verbena stoechadifolia L. Sp. Pl. 19. 1753. Phyla stoechadifolia (L.) Small, Bull. Torrey Club 36: 162. 1909.

Wet thickets, damp, open fields, swampy land bordering lakes and streams, rarely on open, rocky banks, sea level to 1,500 meters; Alta Verapaz; Huehuetenango; Jutiapa; Petén. Southern Florida; Mexico; British Honduras; Honduras; West Indies; northern South America.

Erect shrubs to $1.5 \mathrm{~m}$. tall, or suffruticose and spreading, of ten much branched, the stems strigose, leaves nearly sessile to short-petiolate, the blades thick, oblonglinear, 2-10 cm. long, $0.3-1 \mathrm{~cm}$. (rarely $1.5 \mathrm{~cm}$.) wide, acute, cuneate at the base, the margins serrate-dentate, both surfaces strigose with both simple and malpighiaceous hairs, the veins very conspicuous beneath, the lateral ones numerous, usually 10-14 pairs; peduncles solitary in the leaf axils, usually longer than the leaves; flower spikes at first globose, in age oblong, $2-3 \mathrm{~cm}$. long, $0.5-0.7 \mathrm{~cm}$. in diameter; bracts cuneate obovate; calyx bicarinate, with a line of fine hairs along each keel, $2-2.5 \mathrm{~mm}$. long; corolla white or purplish, $2.5-3.5 \mathrm{~mm}$. long.

Lippia substrigosa Turcz. Bull. Soc. Nat. Moscou, pt. 2: 202. 1863. L. kellermanii Greenm. Field Mus. Bot. 2: 341.1912 (type from Lago de Amatitlán, Guatemala, W. A. Kellerman 6372). L. guatemalensis Gandoger, Bull. Soc. Bot. France 65: 63. 1918 (type from Guatemala, Tuerckheim s.n.). Chichicaste de venado (Guatemala); salvia santa (Quezaltenango); supup (Alta Verapaz).

Wet or dry thickets, oak-pine forest, sometimes on open, rocky slopes, 1,200-2,800 meters; Alta Verapaz; Baja Verapaz; Chimaltenango; Chiquimula; Guatemala; Huehuetenango; Jalapa; Quezaltenango; El Quiché; Sacatepéquez; San Marcos; Santa Rosa; Sololá; Zacapa. Southern Mexico; British Honduras; Honduras; El Salvador; Nicaragua.

Shrubs or trees to $7 \mathrm{~m}$. tall, the branches usually densely viscid-pubescent with harsh, brownish, spreading hairs, sometimes pilose with pale, spreading hairs; leaves on petioles $0.7-3 \mathrm{~cm}$. long, the blades ovate to broadly ovate, ovate-elliptic or lance-ovate, mostly $5-24 \mathrm{~cm}$. long, $2.5-12 \mathrm{~cm}$. wide, acute to acuminate, cordate to abruptly contracted and obtuse at the base or cuneately long attenuate, the surface rugose or finely bullate, scabrous-hispid, usually very rough to the touch, densely hirsute-tomentose or pilose beneath or both surfaces rarely glabrate, the margins crenate-serrate; peduncles usually $4-8$ in each leaf axil, $2.5-6 \mathrm{~cm}$. long, hirsute and usually glandular-pubescent; flower spikes subglobose, at anthesis 10 $20 \mathrm{~mm}$. long, $10-16 \mathrm{~mm}$. wide, in fruit to $28 \mathrm{~mm}$. long and $25 \mathrm{~mm}$. wide; bracts broadly ovate to subreniform, acute or rounded and abruptly acuminate to cuspidate at the apex, hispidulous or glandular-pubescent and ciliate, the lower ones sometimes to $14 \mathrm{~mm}$. long; calyx $2-2.5 \mathrm{~mm}$. long, villous; corolla pale yellow, 4-6 $\mathrm{mm}$. long. 


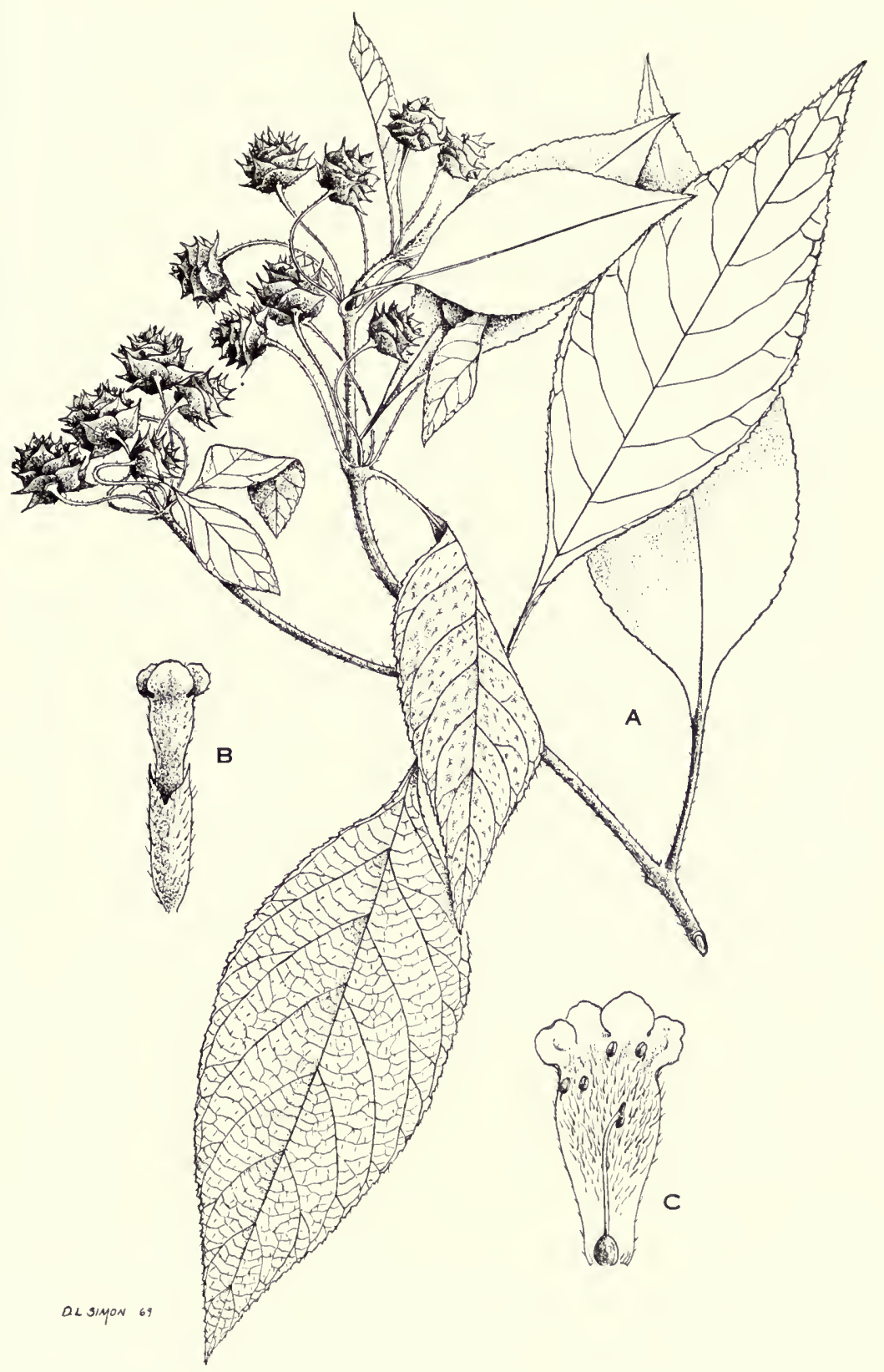

FIG. 40. Lippia substrigosa. A, flowering branch, 1/2 natural size; B, flower, $\times 5$; C, corolla dissected to show pistil and stamens, $\times 5$. 
This plant has been reported from Guatemala as L. umbellata Cav. and some of the material has been determined by Moldenke and cited by him as L. callicarpaefolia HBK. Lippia umbellata, which has been poorly understood and which probably includes $L$. pringlei Briquet, was originally described (Cav. Icon. Pl. 2: 75, t. 194. 1793) as having "flores umbellati, umbellis pluribus axillaribus in ramorum summitatibus" and the illustration clearly shows primary peduncles with several "rays" forming definite dichasia. I have seen no material of $L$. umbellata nor of the closely related $L$. pringlei from either Guatemala or Chiapas. The Mexican L. callicarpaefolia, which in foliage and large flowering heads does resemble L. substrigosa, differs markedly in its dichasial inflorescence and conspicuously colored (rose to purple) bracts.

\section{PETREA L.}

Reference: Moldenke, H. N., A monograph of the genus Petrea, in Fedde, Rep. Sp. Nov. 43: 1-48; 48: 161-221. 1938.

Shrubs, trees, or woody vines; leaves opposite, sub-opposite, or verticillate, the venation prominent, both surfaces often very rough; inflorescences axillary or terminal, racemose, usually elongated and many-flowered; bracts small, caducous; flowers long-pedicellate and often remote on the rachis; calyx tube cylindric or campanulate, costate, 5-lobate, the lobes subequal, elongated, cristate ventrally at the base; corolla salverform, usually blue or violet, rarely white, slightly zygomorphic, the tube urceolate, cylindric, or funnelform, usually pubescent within near the middle, the limb spreading, 5-lobate; stamens 4, didynamous, the filaments very short, inserted near the middle of the corolla tube, included, or the anthers scarcely exserted; anthers oblong or ovate, dorsifixed near the base, the cells opening by an introrse slit; style terminal, the stigma capitate, oblique; overy bilocular, one ovule in each locule; ovules lateral, ascending, sometimes pendent; fruiting calyx accrescent, the lobes subcoriaceous, reticulate-veined; fruit drupaceous, completely enclosed in the accrescent calyx, the exocarp coriaceous, the endocarp hard, of 2 pyrenes.

Perhaps 30 species, in tropical America. One other species occurs in southern Central America.

Petrea volubilis L. Sp. Pl. 626. 1753. P. arborea HBK. f. albiflora Standl. Field Mus. Bot. 11: 140. 1932 (type from Sittee River, Stann Creek District, British Honduras, Schipp 727). P. volubilis var. albiflora (Standl.) Moldenke, Revista Sudamer. Bot. 5: 2. 1937. $P$. volubilis var. pubescens Moldenke in Fedde, Rep. Sp. Nov. 43: 45. 1938. P. volubilis f. albiflora Standl. Field Mus. Bot. 18: 1011. 1938. Colación (Guatemala); corona de la reina and Santa Rita (Petén); cuero de sapo (El Progreso); yochopptzimin (Yucatan, Maya). 


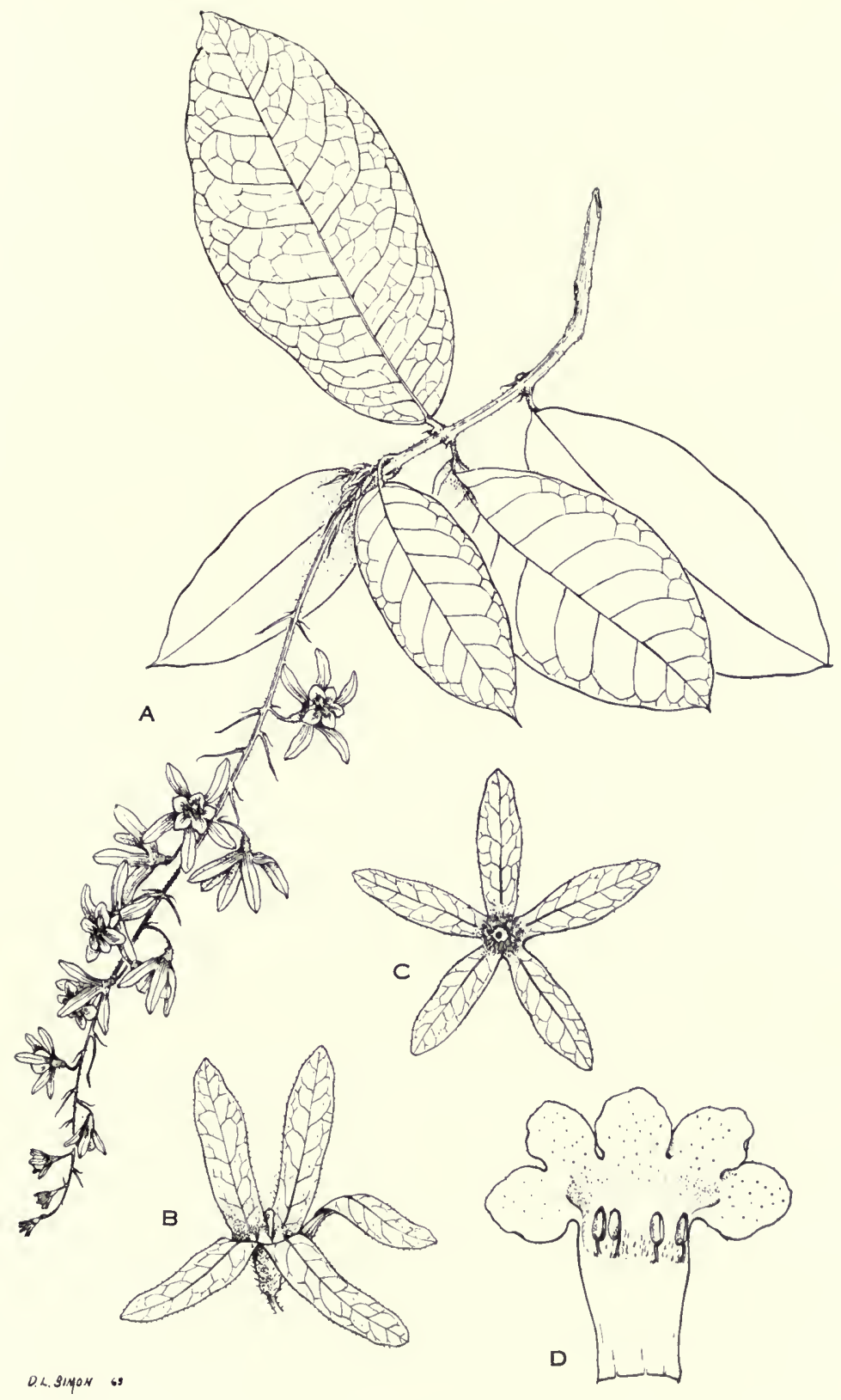

FIG. 41. Petrea volubilis. A, flowering branch, 1/2 natural size; B, accrescent calyx and style, $\times 2 ; \mathrm{C}$, fruiting calyx enclosing fruit, $\times 1 ; \mathrm{D}$, corolla dissected to show stamens, $\times 3$. 
Dry thickets or forest, rocky slopes, near sea level to 1,800 meters; often cultivated; Alta Verapaz; Baja Verapaz; Chimaltenango; Escuintla; Guatemala; Izabal; Jutiapa; Petén; El Progreso; Quezaltenango; El Quiché; Retalhuleu; San Marcos; Santa Rosa; Suchitepéquez; Zacapa. Mexico; British Honduras to El Salvador and Panama; West Indies.

Woody vines or subscandent shrubs, the stems puberulent or hirtellous, sometimes as much as $9 \mathrm{~cm}$. in diameter; leaves short-petiolate, the blades coriaceous, rough to the touch, oblong, obovate, or elliptic-oblong, mostly $6-15 \mathrm{~cm}$. long, acute or obtuse, acute to rounded at the base, entire, scabrous or pilosulous above, scabrous beneath or rather densely pilosulous; racemes usually pendent, solitary in the leaf axils, of ten clustered near the ends of the branches, mostly $8-20 \mathrm{~cm}$. long, lax; bracts linear or linear-lanceolate, $4-8 \mathrm{~mm}$. long, caducous; calyx tube ca. $3 \mathrm{~mm}$. long at anthesis, the lobes oblong, in fruit as much as $2 \mathrm{~cm}$. long, blue or purple (rarely white); corolla tube 6-8 $\mathrm{mm}$. long, usually somewhat puberulent, at least near the top, the lobes minutely puberulent outside, essentially glabrous within; ovary and style glabrous.

This handsome vine is very common in the dry lower Motagua Valley, where it is covered with flowers in late March, and is frequent in many places along the Pacific plains and foothills. It has been introduced into cultivation in many warm regions and in Florida is known as "purple-wreath." This species has been reported from Guatemala as $P$. arborea HBK., a species which is usually arborescent, with sessile or subsessile, often clasping leaves, and apparently confined to the West Indies and South America. The other Central American species is $P$. aspera L., with pedicels and calyx essentially glabrous.

\section{PRIVA Adanson}

References: C. E. Kobuski, A revision of the genus Priva, Ann. Mo. Bot. Gard. 13: 1-35, t. 1-5. 1926; H. N. Moldenke, A monograph of the genus Priva, in Fedde, Rep. Sp. Nov. 41: 1-76. 1936.

Herbaceous annuals or perennials with usually rough pubescence; leaves opposite, sessile or petiolate, the blades membranaceous, dentate; inflorescences racemose, terminal or axillary, the flowers small, pedicellate, bracteate, the small bracts lanceolate or ovate; calyx tubular or cylindric in anthesis, 5-costate, the costae terminating in short teeth, the calyx persistent, accrescent and enclosing the fruit, usually more or less contracted at the orifice; corolla tube cylindric, the limb more or less bilabiate, the 5 lobes spreading, oblique; stamens 4, didynamous, inserted at about the middle of the corolla tube, included or scarcely exserted; anther cells parallel or slightly divergent; ovary bilocular, the ovules 2 or by abortion 1 ; style terminal, stigma bilobate; fruit dry, included in the enlarged calyx, separating at maturity into 2 bilocular or by abortion unilocular cocci, the pericarp hard, the dorsal surface of the cocci echinate, ridged and rugose, or smooth, the inner surface excavated, concave, or plane. 
About 20 species, in tropical America, Asia, and Africa, inclined to be weedy. Only three occur in Guatemala; no others are known in Central America.

Fruiting calyx broadly ovoid, not closely investing the fruit; fruits distinctly

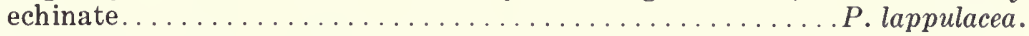

Fruiting calyx globose or nearly so, closely investing the fruit; fruits reticulaterugose to reticulate-verrucose but not echinate.

Pedicels reflexed in fruit; calyx $1.5-2.5 \mathrm{~mm}$. long. ........... mexicana. Pedicels erect in fruit; calyx $3-4 \mathrm{~mm}$. long. ............... aspera.

Priva aspera HBK. Nova Gen. \& Sp. 2: 278. 1817. P. orizabae S. Wats. Proc. Am. Acad. 23: 282. 1888. Chile hueco (Guatemala).

Damp thickets, brushy slopes, sometimes in pine-oak forest, 1,000-2,100 meters; Alta Verapaz; Chimaltenango; Escuintla; Guatemala; Huehuetenango; Jalapa; El Quiché; Sacatepéquez; Sololá. Mexico; Honduras; Nicaragua; Costa Rica.

Erect or ascending annuals, the stems often hollow, acutely tetragonous, puberulent; leaves on petioles $0.3-5 \mathrm{~cm}$. long, the blades ovate or lanceolate-ovate, mostly $4-15 \mathrm{~cm}$. long, rarely to $20 \mathrm{~cm}$. long, acuminate to long-acuminate, cuneate or obtuse at the base, the margins crenate to crenate-dentate, scabrous above, puberulent beneath; racemes terminal or axillary, 6-40 cm. long; flowers of ten remote, short-pedicellate, the pedicels erect in fruit, the bracts lanceolate, usually exceeding the pedicels; calyx at anthesis tubular, $3-4 \mathrm{~mm}$. long, in fruit globose, closely investing the fruit, $3-4 \mathrm{~mm}$. long, obscurely rostrate, usually densely puberulent and bearing some longer, uncinate hairs; corolla blue to purple, 5-7 $\mathrm{mm}$. long; cocci of the fruit 2, the dorsal surface reticulate-rugose, not echinate, the inner surface usually shallowly excavated.

The ripe fruit is black and lustrous.

Priva lappulacea (L.) Pers. Syn. Pl. 2: 139. 1807. Verbena lappulacea L. Sp. Pl. 28. 1753. P. echinata Juss. Ann. Mus. Paris 7: 70. 1806. Pega-pega (Zacapa).

Wet or dry thickets, clearings, waste ground, common near dwellings, sea level to 900 meters; Alta Verapaz; Chiquimula; Escuintla; Guatemala; Izabal; Petén; Retalhuleu; Santa Rosa; Sololá; Zacapa. Southern Florida; Mexico; British Honduras to El Salvador and Panama; West Indies; South America; introduced in the Old World tropies.

Erect, ascending, or decumbent annuals, of ten much branched, to $75 \mathrm{~cm}$. tall, the stems tetragonous, pubescent; leaves on petioles $0.5-4 \mathrm{~cm}$. long, the blades ovate or lanceolate-ovate, $2-10 \mathrm{~cm}$. long, acute or acuminate, rounded or subcordate at the base, the margins crenate-dentate, hispidulous or glabrate above, puberulent beneath; racemes lax, 5-20 cm. long, the flowers short-pedicellate, the 


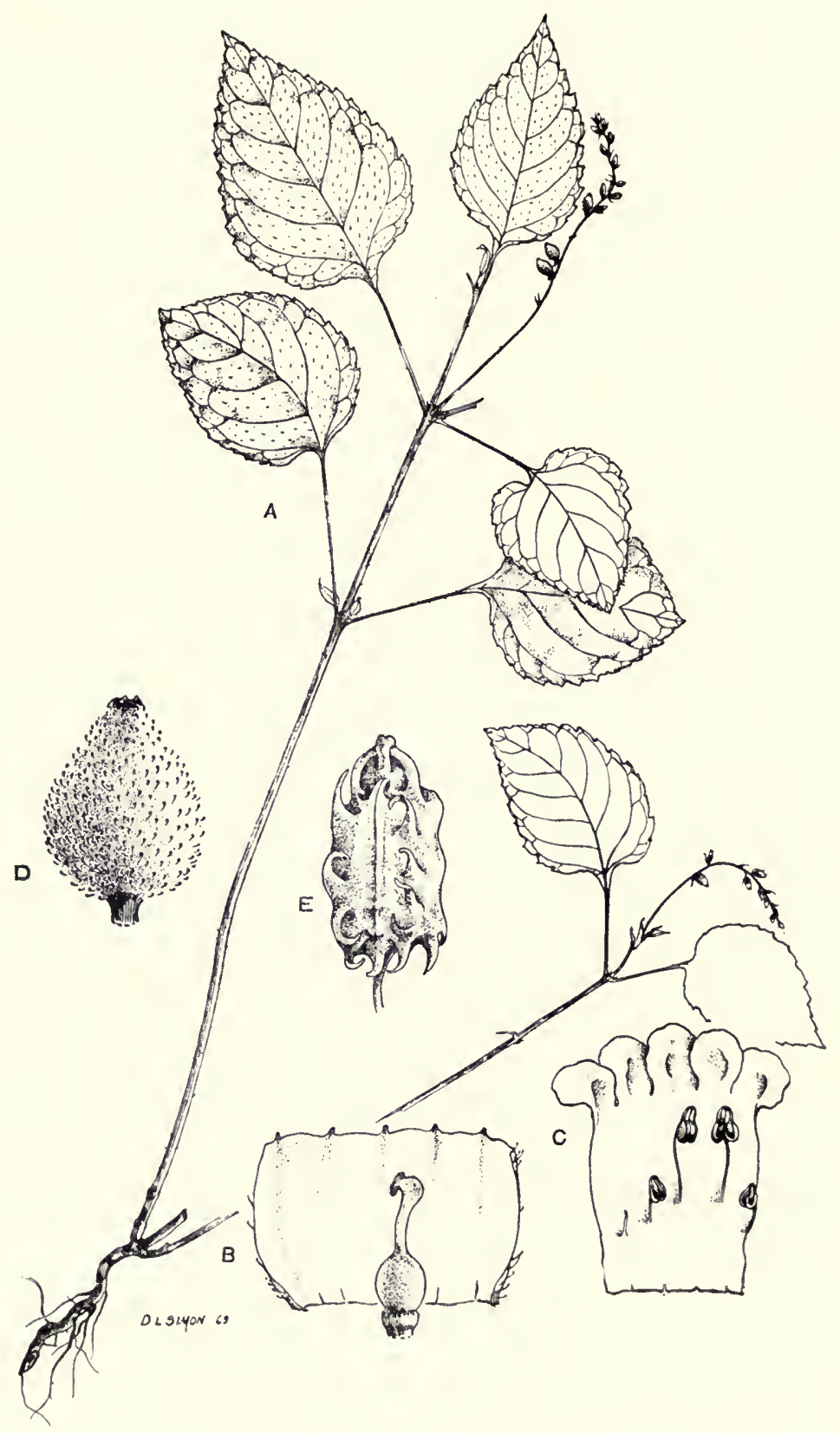

FIG. 42. Priva lappulacea. A, habit, 1/2 natural size; B, calyx opened to show pistil, $\times 10 ; \mathrm{C}$, corolla dissected to show stamens and staminode, $\times 3 ; \mathrm{D}$, fruiting calyx enclosing fruit, $\times 5 ; \mathrm{E}$, mature fruit, $\times 8$. 
bracts narrowly lanceolate, usually shorter than the pedicels; calyx at anthesis tubular, 2-3 mm. long, densely uncinate-hispidulous, in fruit broadly ovoid, appearing inflated, constricted at the apex and often somewhat rostrate, 4-7 mm. long; corolla usually blue or purple, sometimes pink or white, 4-5 mm. long; fruit of 2 bilocular cocci, these echinate dorsally, the inner surface plane or nearly so.

Throughout most of the tierra caliente of Central America this is a common weed, often abundant about dwellings. The fruiting calyces adhere to clothing and even to the feathers of birds by the abundant small uncinate hairs; the common names "pega-pega," and in El Salvador and Honduras "mozote" and "mozotillo," indicate this characteristic.

Priva mexicana (L.) Pers. Syn. Pl. 2: 139. 1806. Verbena mexicana L. Syst. 66. 1784. P. hispida Juss. Ann. Mus. Paris 7: 70. 1806.

Damp thickets and hedges, wooded slopes, sometimes in pine or scrub-oak forest, or a weed in cultivated ground, 50-1,800 meters; Baja Verapaz; Chimaltenango; Escuintla; Guatemala; Jalapa; Petén; Sacatepéquez. Mexico; Honduras.

Erect or decumbent annuals, to $1 \mathrm{~m}$. tall, of ten much branched, the stems tetragonous, pubescent or glabrate; leaves on petioles mostly $0.5-2.5 \mathrm{~cm}$. long, the blades ovate to lanceolate-ovate, acute or acuminate, rounded at the base or the lowest ones subcordate, crenate, hispidulous-strigose above, paler beneath and viscid-puberulent; racemes terminal or axillary, pedunculate, 5-30 cm. long, the bracts lanceolate, equalling or more of ten exceeding the pedicels, these $0.5-1 \mathrm{~mm}$. long, reflexed in age; calyx densely uncinate-hispidulous, cylindric at anthesis, 1.5-2.5 mm. long, in fruit 2-3 mm. long and closely investing the fuit; corolla usually blue to purple, sometimes white, about twice as long as the calyx; fruit composed of 2 unilocular cocci, these reticulate-verrucose dorsally, not echinate, somewhat concave or excavated on the inner surface, separating easily.

\section{REHDERA Moldenke}

Reference: H. N. Moldenke, A monogiaph of the genus Rehdera, in Fedde, Rep. Sp. Nov. 39: 47-55. 1935.

Trees; leaves subcoriaceous, triplinerved or with 5-7 pairs of lateral veins; inflorescences short-racemose, the flowers small, bracteate; calyx tubular, with 5 costae terminating in 5 short teeth, the fruiting calyx usually splitting into 5 segments and early deciduous; corolla salverform, the tube cylindric, about equalling the calyx, the 5 lobes long and narrow, tomentose or pilose within; perfect stamens 4, included, inserted near the apex of the corolla tube; anthers oblong, introrse, dorsifixed near the base; style simple, terminal, the stigma subcapitate, obscurely bilobate; ovary bicarpellate, each carpel bilocular, the ovules attached basally; fruit oblong, dorsally compressed, lustrous, composed of 2 cocci, of ten more or less marginally winged, rounded or subretuse at the apex; seed linear. 
Leaf blades usually obtuse or rounded at the apex (rarely acute or abruptly shortacuminate); fruiting calyces sinuately denticulate. $R$. trinervis.

Leaf blades acuminate to long-acuminate; fruiting calyces subtruncate.

R. penninervia.

Rehdera penninervia Standl. \& Moldenke in Fedde, Rep. Sp. Nov. 39: 50. 1935. Palo blanco (fide Standley); raspa sombrero (Petén).

Upland limestone forest or thickets, 300 meters or less; Petén (type from Uaxactún, H. H. Bartlett 12317). British Honduras.

Trees to $25 \mathrm{~m}$. tall, the trunk $45-75 \mathrm{~cm}$. in diameter, the branchlets glabrate; leaves on slender, of ten minutely puberulent petioles $5-15 \mathrm{~mm}$. long, the blades subcoriaceous, lustrous, 5-10 cm. long, with 5-7 pairs of lateral veins, lance-oblong or elliptic-oblong, long-acuminate, cuneate at the base, the margins entire, glabrous on both surfaces or sometimes barbellate beneath in the axils of the costae and lowermost veins; racemes axillary and terminal, 1-3 cm. long, sometimes branched, with few or many flowers; pedicels $1 \mathrm{~mm}$. long or less; bracts soon deciduous, linear or narrowly triangular, 1-3 mm. long; calyx tubular at anthesis, subtruncate, the 5 costae terminating in 5 minute teeth, glabrous outside, sericeous within, ca. $5 \mathrm{~mm}$. long, in fruit cupuliform, truncate, soon deciduous; corolla white, glabrous outside, the tube 4-5 mm. long, the lobes 3-4 mm. long, tomentose to pilose inside; fruit oblanceolate-oblong, compressed, about $17 \mathrm{~mm}$. long and $8 \mathrm{~mm}$. broad.

The crushed leaves are reported to have a distinctive odor.

Called "hinge hinge" and "roble del mico" in British Honduras.

Rehdera trinervis (Blake) Moldenke in Fedde, Rep. Sp. Nov. 39: 52. 1935. Citharexylum trinerve Blake, Proc. Biol. Soc. Wash. 34: 45. 1921. C. macrocarpum Standl. Journ. Wash. Acad. Sci. 14: 243. 1924. Rehdera mollicella Standl. \& Moldenke in Fedde, Rep. Sp. Nov. 39: 51.1935 (type from Baja Verapaz, Kellerman 7992).

Dry, brushy, often rocky plains and hillsides, 200-800 meters; Baja Verapaz; Chiquimula; Jutiapa. Mexico; Honduras; El Salvador; Nicaragua; Costa Rica.

Trees to $20 \mathrm{~m}$. tall, the branches puberulent or glabrate; leaves on puberulent petioles 5-15 $\mathrm{mm}$. long, the blades subcoriaceous, broadly or narrowly elliptic or obovate, 2-9 cm. long, usually rounded or obtuse, rarely acute or abruptly shortacuminate at the apex, cuneate or obtuse and abruptly contracted at the base, the margins entire, lateral veins 3-7 pairs, plinerved or not, glabrate and of ten lustrous above, glabrous or more or less pubescent beneath, or pubescent only along the costae; racemes axillary, usually 1-2 cm. long, glabrous or puberulent, with few or many sessile flowers; bracts linear or narrowly triangular, puberulent, usually 1-3 mm. long; calyx tubular at anthesis, in fruit cupuliform, glabrous or minutely puberulent outside, sericeous inside, 4-6 mm. long, 5-costate and denticulate; corolla white, cream, or greenish, glabrous outside, the tube 4-6 $\mathrm{mm}$. long, the lobes 


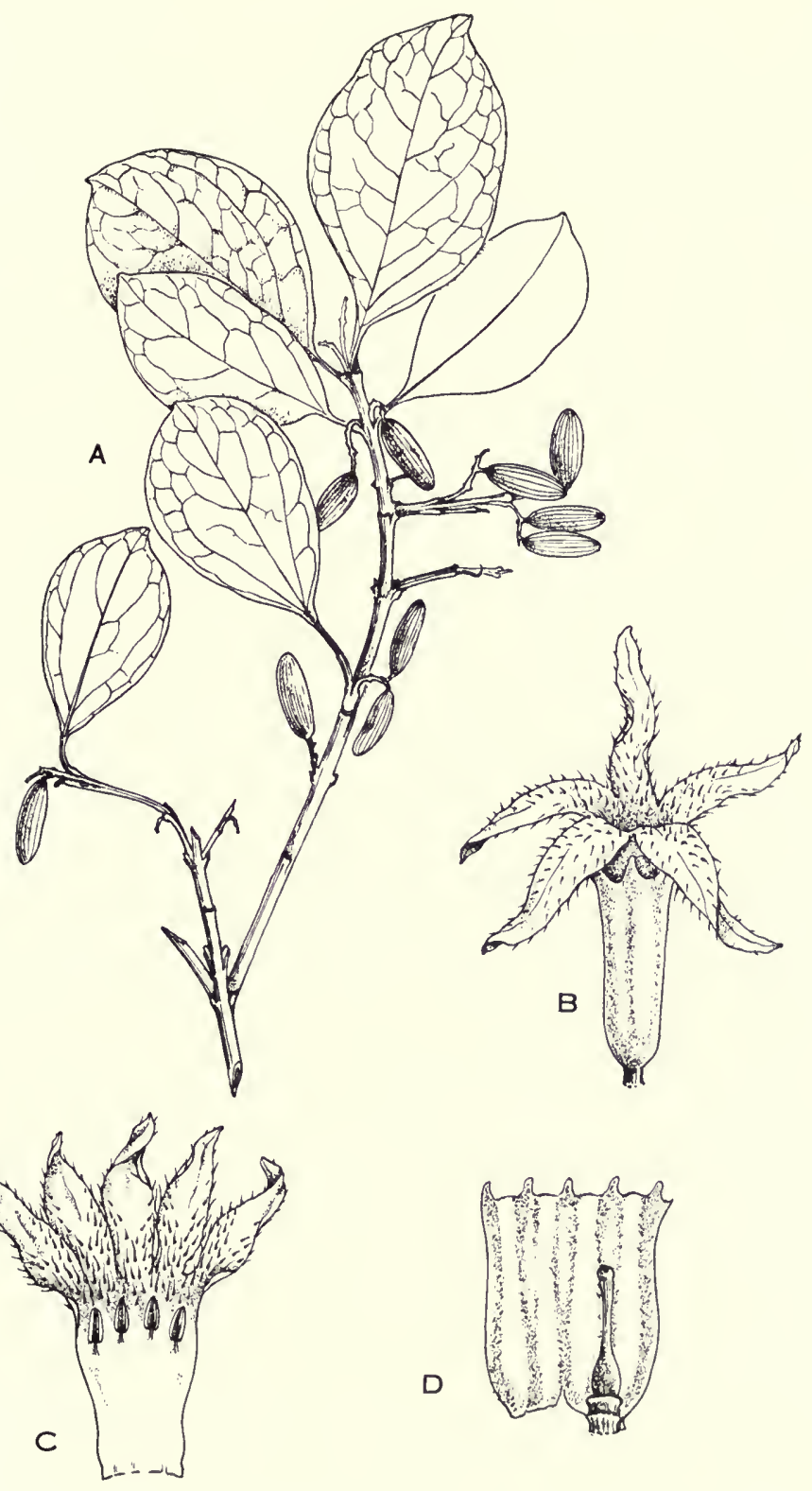

D.LSingN 69

FIG. 43. Rehdera trinervis. A, fruiting branch, $1 / 2$ natural size; $B$, flower, $\times 4$; $\mathrm{C}$, corolla opened to show stamens, $\times 4 ; \mathrm{D}$, calyx opened to show pistil, $\times 5$. 
pilose or tomentose inside, 4-5 $\mathrm{mm}$. long; fruit oblong or obovate-oblong, $820 \mathrm{~mm}$. long, glabrous and lustrous.

Since Standley and Moldenke described $R$. mollicella, numerous intermediate specimens from various localities have been collected, in which some of the smaller leaves appear triplinerved, but with 5-7 pairs of lateral veins in some larger leaves, these anastomosing near the margin or not. Standley 28593 from Honduras, Standley 9412 from Nicaragua, and Jiménez 312 from Costa Rica have leaves that are essentially glabrous but with $5-7$ conspicuous pairs of lateral veins. Standley 28600 from Honduras has uniformly small, triplinerved leaves, but they are densely pubescent beneath. Molina 14321 and 14350 from Honduras have most leaves triplinerved but all have patches of indument along the costae and most have sparsely scattered pubescence on the lower surfaces. Calyces of these intermediate specimens are usually glabrous, but a few on Molina 14321 are somewhat puberulent.

\section{STACHYTARPHETA Vahl}

Annual or perennial herbs or low shrubs, glabrous or pubescent; leaves mostly opposite, the blades dentate to serrate; inflorescences terminal, spicate, the spikes short or long, densely or laxly flowered, the flowers numerous, sessile or partly immersed in the rachis of the spike, each flower solitary in the axis of a bract; calyx tubular, 5-dentate, the teeth usually unequal; corolla small, white to blue, purple, pink, or red, the tube cylindric, the limb spreading, 5-lobate; stamens 2, inserted above the middle of the corolla tube, included, staminodes 2 , small and inconspicuous; anthers not appendaged, the cells divergent, dehiscent in one continuous line; ovary bilocular, each locule uniovulate; style elongated, the stigma terminal, sub. capitate; ovules attached laterally near the base of the locule; fruit dry, oblong: linear, included in the persistent calyx, splitting at maturity into 2 hard cocci; endosperm none.

Perhaps 30 or 40 species, in tropical America. One other species, S. mutabilis (Jacq.) Vahl, is known from Central America.

Leaves linear or oblong-linear, 6-10 times longer than broad ......S. angustifolia. Leaves not as above.

Rachis of inflorescence at maturity thick and stout, $4-7 \mathrm{~mm}$. in diameter.

S. jamaicensis.

Rachis of inflorescence at maturity slender, less than $4 \mathrm{~mm}$. in diameter.

Mature rachis usually less than $2 \mathrm{~mm}$. in diameter; calyx $4-6 \mathrm{~mm}$. long.

Mature rachis 2-3.5 $\mathrm{mm}$. in diameter; calyx $7-12 \mathrm{~mm}$. long.

S. cayennensis.

Bracts conspicuously outcurved; leaves glabrate or the pubescence inconspicuous, usually confined to costae and veins of lower surface.

S. miniacea.

Bracts appressed or only slightly divergent; leaves usually pubescent on both surfaces............................... frantzii. 
Stachytarpheta angustifolia (Mill.) Vahl, Enum. Pl. 1: 205. 1804. Verbena angustifolia Mill. Gard. Dict. ed. 8, no. 15. 1768.

Open places, clearings, weedy fields, often near wet places or along roadsides, sea level to 900 meters; Petén. Mexico; British Honduras; Honduras; West Indies; northern South America.

Erect annuals, to $1 \mathrm{~m}$. tall, essentially glabrous, the stems terete or subterete; leaves linear or oblong linear, 4-14 cm. long, usually less than $1 \mathrm{~cm}$. wide, rarely to $1.5 \mathrm{~cm}$., attenuate at each end, serrate-dentate, often somewhat hirsutulous beneath on the veins; mature spikes of inflorescence usually stout, $3-5 \mathrm{~mm}$. wide, 10-40 cm. long; bracts ovate or lanceolate, subulate-acuminate, 5-6 mm. long; calyx 6-7 mm. long; corolla blue or purple.

Stachytarpheta cayennensis (L. Rich.) Vahl, Enum. Pl. 1: 208. 1804. Verbena cayennensis L. Rich., Act. Soc. Hist. Nat. Paris 1: 105. 1792. S. guatemalensis Moldenke, Carnegie Inst. Wash. Publ. 522: 181.1940 (type from Cobán, Alta Verapaz, Tuerckheim II. 1823). S. tabascana Moldenke, Phytologia 1: 437. 1940. S. guatemalensis f. albiflora Moldenke, Phytologia 9: 99. 1963. Styetolok (Alta Verapaz, Quecchí); San Diego vervena (Petén).

Damp thickets, forest, or swamps, sometimes in pine forest, of ten a weed in waste places, sea level to 1,500 meters; Alta Verapaz; Chimaltenango; Izabal; Petén. Mexico; British Honduras to Panama; West Indies; South America; said to be naturalized in some parts of the Old World.

Plants erect and stiff, branching, to $1 \mathrm{~m}$. tall, sometimes suffrutescent below, the stems subterete, pubescent or glabrate; leaves petiolate, the blades ovate or elliptic, 3-10 $\mathrm{cm}$. long, rounded to acute at the apex, cuneate or attenuate to the base, the margins crenate-serrate, usually scaberulous above, usually glabrate beneath, of ten strigillose on the veins; inflorescence mostly $10-40 \mathrm{~cm}$. long, glabrous or nearly so, the rachis very slender, usually $2 \mathrm{~mm}$. or less in diameter; bracts linear or lanceolate, of ten subulate, $3.5-5 \mathrm{~mm}$. long; calyx 4-6 $\mathrm{mm}$. long; corolla usually blue or purple, rarely pink or white, the limb to $5 \mathrm{~mm}$. broad.

The characters Moldenke uses in separating S. guatemalensis and $S$. tabascana from $S$. cayennensis do not hold in all specimens determined by him.

The Indians of Alta Verapaz employ the plant as a supposed remedy for malaria and other fevers. In British Honduras it is used to treat dysentery.

Called "mozote" in Honduras and "wild verbena" and "camacolal" (Maya) in British Honduras. 


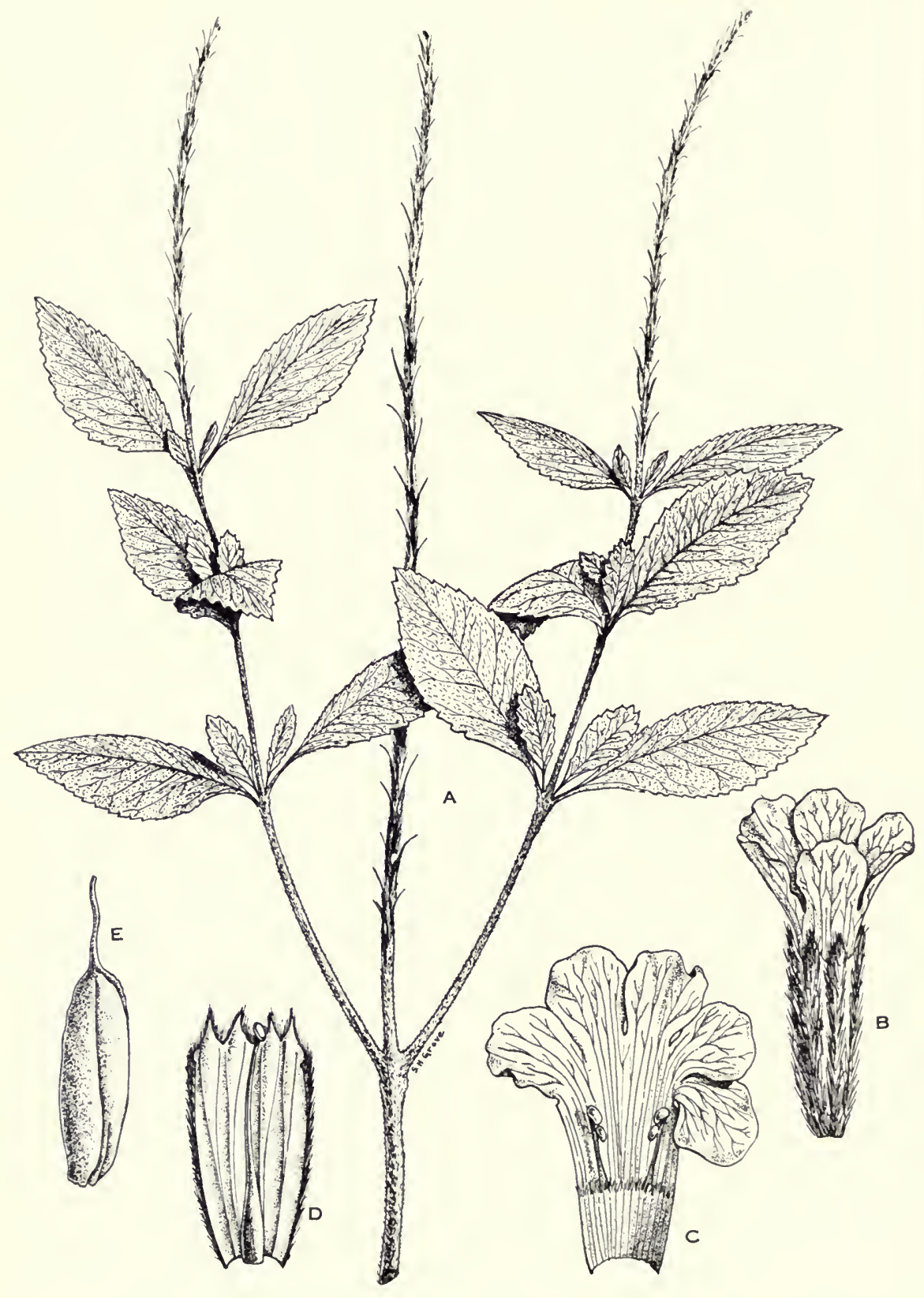

FIG. 44. Stachytarpheta frantzii. A, flowering and fruiting branches, $1 / 2$ natural size; $\mathrm{B}$, flower, $\times 5 ; \mathrm{C}$, corolla dissected to show stamens, $\times 5 ; \mathrm{D}$, calyx opened to show pistil, $\times 5$; E, fruit, $\times 5$. 
Stachytarpheta frantzii Polak. Linnaea 41: 593. 1877. S. frantzii var. patentiflora Moldenke, Phytologia 1: 430. 1940 (type from Guatemala, Tonduz 626). S. guatemalensis var. lundelliana Moldenke, l.c. S. robinsoniana Moldenke, Carnegie Inst. Wash. Publ. 522: 182. 1940. Cola de armado (Guatemala); pije de gato (Jutiapa).

Damp fields or thickets, 150-1,500 meters; Guatemala; Huehuetenango; Jutiapa; Santa Rosa. Southern Mexico to Costa Rica.

Annuals or perennials to $1 \mathrm{~m}$. tall, herbaceous throughout or suffrutescent below, usually much branched, the stems often tetragonous, pilose, tomentose, or glabrate; leaves on winged petioles or the blades often cuneate to the base, ovate or oblong-ovate, $3-10 \mathrm{~cm}$. long, acute or obtuse, coarsely serrate, scabrous to pilose or strigose-pubescent above, pubescent to tomentose beneath, often densely so; inflorescence $8-30 \mathrm{~cm}$. long, the rachis slender, usually $2-3 \mathrm{~mm}$. in diameter, densely or sparsely pilosulous or glabrate, many-flowered; bracts narrowly lanceolate, 6-8(9) mm. long, appressed or slightly divergent; calyx 7-11(12) mm. long; corolla normally blue, violet, or purple, rarely white, red, or pink, the tube 10$16 \mathrm{~mm}$. long.

This has been reported from Guatemala as S. mutabilis (Jacq.) Vahl, a more robust plant with the rachis of the inflorescence often 5-6 $\mathrm{mm}$. in diameter.

Stachytarpheta jamaicensis (L.) Vahl, Enum. Pl. 1:206. 1804. Verbena jamaicensis L. Sp. Pl. 19. 1753. Stachytarpheta jamaicensis f. albiflora Standley, Field Mus. Bot. 4:320.1929. Chilillo (Jutiapa).

Usually on sea beaches, sometimes along roadsides, sea level to 900 meters; Izabal; Jutiapa. Southern United States; Mexico; British Honduras to Panama; West Indies; northern South America.

Erect herbs to $1 \mathrm{~m}$. tall, essentially glabrous throughout, the stems terete or obscurely tetragonous; leaves petiolate, the blades usually broadly ovate to oblongovate, sometimes oblong-elliptic, $3-10 \mathrm{~cm}$. long, obtuse or acute, cuneate at the base and usually long-decurrent, coarsely serrate; inflorescence glabrous, stiff, stout, the mature rachis $4-7 \mathrm{~mm}$. in diameter, $10-70 \mathrm{~cm}$. long; bracts lanceolate or oblong-lanceolate, $4-6 \mathrm{~mm}$. long; calyx 5-7 mm. long; corolla usually blue or purple, rarely white.

Called "verbena" in Honduras and, fide Standley, “mes" (Quecchí); "ibinxiu” and "talche” (Yucatan, Maya).

Stachytarpheta miniacea Moldenke, Phytologia 1: 170. 1935. S. petenensis Moldenke, Phytologia 9: 99. 1963 (type from Dos Lagunas, Petén, Contreras 1563). 
Along roadsides or in thickets or clearings, 200 meters or less, Petén. Mexico (Campeche) and British Honduras (type from Freshwater Creek Reserve, Corozal District, R. S. Pelly 7).

Erect annuals or perennials, sometimes suffrutescent below, to $1 \mathrm{~m}$. tall, the stems subterete, puberulent or glabrate; leaves petiolate, the blades lance-oblong, $3-13 \mathrm{~cm}$. long, 1.5-3.5 cm. wide, acute at apex, long-attenuate and usually decurrent to the base of the petiole, coarsely serrate, glabrate on both surfaces or puberulent beneath; inflorescences slender, the rachis 2-3.5 mm. in diameter, 15-40 cm. long, sparsely pilosulous; bracts narrowly lanceolate, 8-11 $\mathrm{mm}$. long, conspicuously outcurved; calyx about equalling the bracts; corolla dull red.

This appears to be closely related to $S$. frantzii; the bracts of the latter are not as conspicuously divergent and its leaves are usually pubescent on both surfaces.

\section{TAMONEA Aublet}

Erect, essentially annual, branched herbs, sometimes suffrutescent below; leaves small, opposite, short-petiolate, dentate or incised; inflorescences spicate or racemose, terminal and axillary, few-flowered, the flowers remote, small, sessile or short-pedicellate, bracteate; calyx tubular in anthesis, campanulate in fruit, subtruncate, costate, the 5 costae prolonged into short teeth; corolla blue, the tube cylindric, slightly ampliate above, the 5 lobes spreading, oblique; stamens 4 , didynamous, included, the filaments inserted about the middle of the corolla tube, the 2 longer ones usually bearing hump-like appendages below the anthers; anthers ovate, the cells parallel; ovary bicarpellate with 4 almost completely separated locules, each locule uniovulate; style terminal, stigma oblong, oblique; ovules attached laterally near the base of the locule; fruit drupaceous, but becoming nutlike in ours, globose or turbinate, little exserted from the accrescent calyx, obtuse or with 4 obscure lobes at the apex, sometimes spinose at the apex, the exocarp only slightly fleshy, the endocarp hard; endosperm none.

We use the generic name Tamonea Aublet for this verbenaceous genus, following Miss Green in Rehder, Weatherby, Mansfeld \& Green (Kew Bull. 1935: 508. 1936). Dr. Williams has pointed out (Fieldiana: Bot. 29: 574. 1963) that Aublet obviously changed the name of the melastomaceous "Tamonea" while the work in which the two "Tamoneas" was going through press and used Fothergilla for the melastome. Aublet's obvious intent should be followed.

Perhaps four or five species in tropical America. Only one has been found in Central America.

Tamonea spicata Aubl. Pl. Guian. 660, t. 268. 1775. Ghinia spicata Moldenke, Phytologia 1: 169. 1935.

In savannas, about 100 meters; Alta Verapaz. British Honduras; Nicaragua; West Indies; South America. 


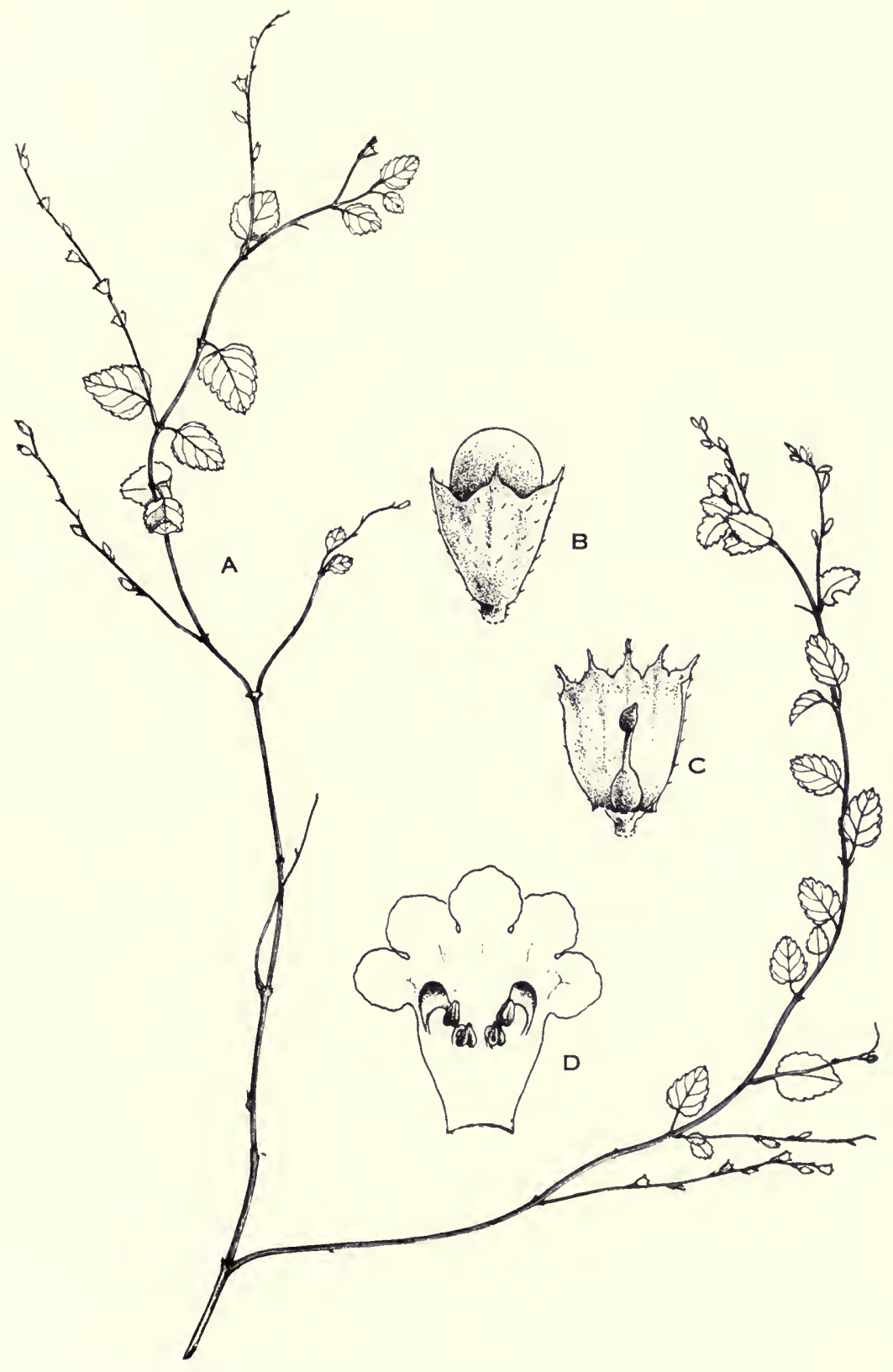

FIG. 45. T'amonea spicata. A, habit, 1/2 natural size; B, fruit partially enclosed in calyx, $\times 5 ; \mathrm{C}$, calyx opened to show pistil, $\times 5 ; \mathrm{D}$, corolla dissected to show stamens, $\times 4$. 
Slender, branched herbs to $1 \mathrm{~m}$. tall, the stems tetragonous, puberulent with small, usually curved hairs; leaves on petioles $3-13 \mathrm{~mm}$. long, the blades ovate to broadly ovate, $0.5-2.5 \mathrm{~cm}$. long, obtuse, truncate at the base, coarsely crenate or incised-serrate, sparsely or rather densely pilosulous; racemes $3-8 \mathrm{~cm}$. long, the pedicels ca. $2 \mathrm{~mm}$. long; calyx at anthesis $4 \mathrm{~mm}$. long; corolla blue, $6-7 \mathrm{~mm}$. long; fruit 3-4 mm. long, glabrous, not spinose at the apex.

The Mexican T. curassavica (L.) Pers. and the West Indian $T$. subbiflora Urb. \& Ekm., which might be confused with ours, have fruits which are spinose at the apex.

\section{VERBENA L.}

Reference: Lily M. Perry, A revision of the North American species of Verbena, Ann. Mo. Bot. Gard. 20: 239-362. 1933.

Annual or perennial herbs, the stems erect to prostrate, glabrous or pubescent; leaves opposite, dentate, serrate, or variously lobate or dissected; inflorescence spicate, the spikes terminal, densely or laxly flowered, short and headlike or elongated, sometimes appearing paniculate, the flowers usually sessile, inconspicuous or showy; calyx tubular, with 5 costae terminating in 5 unequal teeth; corolla salverform or funnelform, the tube straight or curved, the limb obscurely bilabiate, with 5 lobes; stamens 4, didynamous, inserted in the upper half of the corolla tube; anthers ovate, the 2 cells parallel or slightly divergent; style short, the stigma bilobate; ovary bicarpellate, each carpel bilocular, each locule uniovulate; fruit usually enclosed in the calyx, dry, separating into 4 linear or oblong trigonous cocci, each with one seed.

About 100 species, almost all American. Only the following are known from Central America. Two of the garden verbenas, $V$. teucrioides Gill. \& Hook. and V. tenuisecta Briq., both native of South America, are widely grown in Guatemala at all elevations, but there is no evidence of their having become naturalized.

Leaves deeply lobate, cleft, incised, or dissected.

Inflorescence short and compact, 1-2 cm. long; calyx 4-7 mm. long.

V. teucriffolia.

Inflorescence long and slender, $3-45 \mathrm{~cm}$. long; calyx less than $3 \mathrm{~mm}$. long.

V. menthaefolia.

Leaves crenate-serrate to serrate, but never lobate, incised, nor dissected.

Stems hirsute-hispid to pilose; leaves mostly lanceolate to broadly elliptic, the margins coarsely crenate-serrate; bracts usually not more than half as long

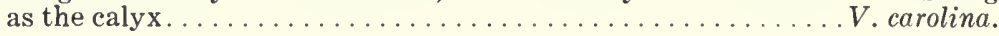

Stems glabrous or sparsely strigose; leaves mostly oblanceolate to spatulate, the margins serrate; bracts usually equalling or two-thirds as long as the calyx

$V$. litoralis.

Verbena carolina L. Syst. ed. 10. 852. 1759. V. polystachya HBK. Nova Gen. \& Sp. 2:274. 1818. V. hirsuta Mar't. \& Gal. Bull. 

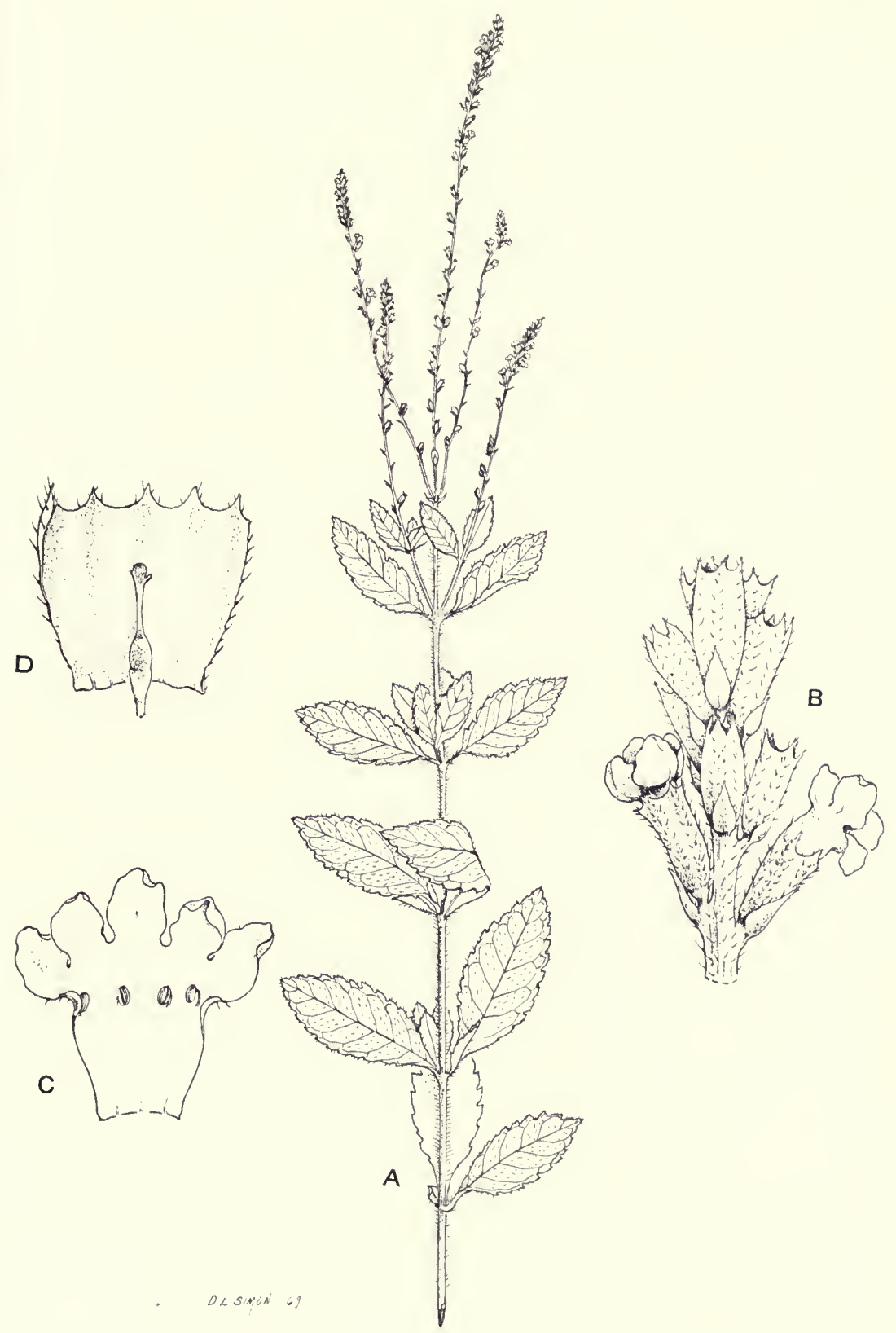

Fig. 46. Verbena carolina. A, habit, $1 / 2$ natural size; B, flowers, buds, and calyces, showing subtending bracts, $\times 6$; C, corolla dissected to show stamens, $\times 8$; D, calyx opened to show pistil, $\times 10$. 
Acad. Brux. 11 (2): 321. 1844. V. mollis Mart. \& Gal. l.c. 323. V. paucifolia Mart. \& Gal. l.c. 324. Dori (Alta Verapaz, Quecchí); chichavac (Chimaltenango); verbena (Guatemala).

Damp or dry thickets, meadows, fields, frequently a weed in cultivated ground, sometimes in pine-oak forest, rarely on sand bars; usually 1,300-3,100 meters, rarely at 85 meters; Alta Verapaz; Chimaltenango; Guatemala; Huehuetenango; Izabal; Jalapa; Quezaltenango; El Quiché; Santa Rosa; Sololá. Arizona; Mexico; El Salvador; Honduras.

Annuals or perennials, erect, usually branching, the stems hirsute-hispid to pilose; leaves subsessile or narrowed into a short petiole, the blades lanceolate to subelliptic, $2-8 \mathrm{~cm}$. long, obtuse or acute, the margins coarsely crenate-serrate, somewhat strigose above, hirsute-strigose beneath, especially on costa and veins; inflorescence often irregularly disposed and appearing paniculate, $3-30 \mathrm{~cm}$. long, many-flowered, of ten interrupted in fruit; bracts ovate, acuminate, ciliate, usually not more than half as long as the calyx; calyx $1.5-2 \mathrm{~mm}$. long, the teeth connivent in fruit; corolla ca. $2 \mathrm{~mm}$. long, pale blue, lavender, or white; fruit ca. $1.5 \mathrm{~mm}$. long.

This has been reported from Guatemala as $V$. ehrenbergiana Schauer.

Verbena litoralis HBK. Nova Gen. \& Sp. 2: 276, t. 13\%. 1818. V. affinis Mart. \& Gal. Bull. Acad. Brux. 11(2): 322. 1844. V. hansenii Greene, Pittonia 3: 308. 1898. V. litoralis var. albiflora Moldenke, Phytologia 1:432. 1940. Verbena; verbena cimarrona; verbena fina; cotacám (Quecchí, fide Standley).

Wet or dry thickets, meadows, rocky slopes, often a weed in cultivated ground, sometimes in pine-oak forest, 85-3,000 meters; Alta Verapaz; Baja Verapaz; Chimaltenango; Guatemala: Huehuetenango; Izabal; Jalapa; Jutiapa; Petén; Quezaltenango; Retalhuleu; Sacatepéquez; San Marcos; Santa Rosa; Totonicapán. Mexico to Panama; South America.

Annual or perennial herbs, to $1.5 \mathrm{~m}$. tall, branched above, the stems tetragonous, glabrous or sparsely strigose; leaves subsessile or short-petiolate, the blades oblanceolate to spatulate, of ten very narrowly so, 2-10 cm. long, acute, serrate, sparsely strigillose on both surfaces, usually rough to the touch, prominently veined beneath; inflorescence often appearing paniculate, the spikes slender, densely flowered or interrupted, the flowers often congested near the end of the rachis; bracts ovate-lanceolate, acuminate, ciliate, two-thirds as long as, or equalling the calyx; calyx 2-2.5 mm. long, strigillose, the teeth minute; corolla tube longer than the calyx, the limb $2.5-3 \mathrm{~mm}$. broad, blue, purple, or white; fruit scarcely $2 \mathrm{~mm}$. long. 
Common weeds of Central America. In Alta Verapaz the plant has been employed as a remedy for various fevers, as well as influenza and small-pox.

Called verbena de montaña in British Honduras.

Verbena menthaefolia Benth. Pl. Hartweg. 21. 1839. V. setosa Mart. \& Gal. Bull. Acad. Brux. 11(2): 321. 1844. Telran; verbena.

Open fields or hillsides, 800-1,200 meters; Huehuetenango (between Nentón and Las Palmas, Steyermark 51655). Southwestern United States; Mexico.

Perennial plants, erect or decumbent, branched, the stems sparsely and minutely hispidulous; leaves tapering at the base into a marginate petiole, the blades 1-5 cm. long, deeply lobed or incised, the divisions narrow, remotely serratedentate, more or less strigillose on both surfaces; inflorescence irregularly disposed and appearing paniculate, very slender, usually much elongated, $3-45 \mathrm{~cm}$. long, many-flowered, interrupted; bracts ovate-lanceolate, acuminate, usually shorter than the calyx, ciliate and sparsely strigillose; calyx $2-2.5 \mathrm{~mm}$. long, strigillose, the teeth minute; corolla ca. $4 \mathrm{~mm}$. long; fruit $2-2.5 \mathrm{~mm}$. long.

Verbena teucriifolia Mart. \& Gal. Bull. Acad. Brux. 11, pt. 2: 322. 1844. Verbena de monte (Huehuetenango).

Usually in open, grassy or stony hillsides, fields, roadsides, sometimes in scrub forest, 1,500-3,100 meters; Chimaltenango; Guatemala; Huehuetenango; Quezaltenango; San Marcos; Sololá; Totonicapán. Southern Mexico.

Annuals or perennials, prostrate, of ten forming small, dense mats, usually much branched, hirtellous or glabrate; leaves 1-3 cm. long, cuneate at the base and short-petiolate, incised-pinnatifid, the segments linear-oblong, obtuse or subacute, strigillose or glabrate; inflorescence sessile or short-pedunculate, $1-2 \mathrm{~cm}$. long, few-flowered; bracts ca. half as long as the calyx, lanceolate; calyx 4-7 $\mathrm{mm}$. long, hirtellous, accrescent, in fruit of ten contracted at orifice with the aristiform lobes twisted together; corolla rose-purple, the tube slightly longer than the calyx, the limb 4-7 mm. broad; fruit 2.5-3 $\mathrm{mm}$. long, the cocci reticulate-scrobiculate, the inner face muriculate or almost smooth.

Inconspicuous plants, common in the region of Quezaltenango.

\section{VITEX L.}

Reference: Moldenke, Harold N. Materials toward a monograph of the genus Vitex, I-X. Phytologia 5: 142-176, 186-224, 257-280, 293-336, 343-393, 404-507. 1955-1957; 6: 13-64, 70-192. 1957. 
Trees or shrubs, glabrous or variously pubescent; leaves opposite, palmately compound, petiolate, the leaflets $3-7$, petiolulate, usually entire, the terminal leaflet largest and the 2 lower ones often greatly reduced; inflorescence cymose, the cymes short and dense or lax and spreading, in axillary or terminal panicles, the flowers more or less zygomorphic; calyx campanulate or cupuliform, with 5 teeth or lobes; corolla usually blue, violet, or white, salverform, the tube short, the limb oblique, spreading, somewhat bilabiate, the upper lip bifid, the lower and larger lip trifid; stamens 4, didynamous, often exserted, the filaments inserted on the corolla tube; anther cells parallel, divergent, or arcuate, attached near their apex, dehiscent by longitudinal slits; ovary bicarpellate, the style terminal, filiform, shortbifid at the apex; the 4 locules of the ovary uniovulate, the ovules attached laterally; fruit drupaceous, the endocarp hard, the exocarp juicy; seeds erect, without endosperm.

Perhaps 250 species, in the tropics of both hemispheres. Three occur in Guatemala and a few others are known from southern Central America.

Leaflets 3 ; calyx cupuliform, subtruncate, remotely and minutely denticulate.

Leaflets 5 (rarely 7); calyx campanulate, lobate or dentate.

V. cooperi.

Leaflets glabrous beneath or nearly so; calyx with triangular-oblong to linear, of ten reflexed lobes $1.5-2.5 \mathrm{~mm}$. long............... kuylenii.

Leaflets tomentulose or velutinous beneath; calyx with acute teeth $0.5-1 \mathrm{~mm}$.

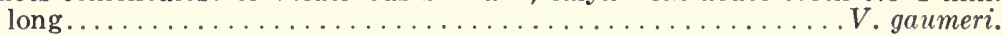

Vitex cooperi Standl. Trop. Woods 16:26. 1928 (nomen); Field Mus. Bot. 4: 256. 1929.

Damp thickets, sea level to 600 meters; Izabal. Atlantic coast of Honduras; Nicaragua; Costa Rica; Panama.

Large trees to $26 \mathrm{~m}$. tall, to $75 \mathrm{~cm}$. in diameter, branchlets first puberulent, then glabrate; leaves on minutely puberulent petioles $1.3-9.5 \mathrm{~cm}$. long, 3 -foliate, the petiolules 1-8 $\mathrm{mm}$. long, the blades mostly $4-22 \mathrm{~cm}$. long, the central blade much larger than the lateral ones, chartaceous, broadly elliptic, elliptic-oblong, or obovate, short-acuminate or abruptly acuminate, acute or abruptly contracted at the base, glabrous above, puberulent beneath when young, glabrate in age; inflorescences axillary, cymose, $3.5-14 \mathrm{~cm}$. long, usually 3 or 4 times dichotomously branched, peduncles $4-8 \mathrm{~cm}$. long, finely puberulent, the flowers on puberulent pedicels 1-3 mm. long; calyx 1-1.5(2) mm. long, cupuliform, subtruncate, puberulent, remotely and minutely denticulate; corolla blue to purple, the tube $3-4 \mathrm{~mm}$. long, densely glandular-puberulent, villous in throat, the lobes $3-6 \mathrm{~mm}$. long, of ten minutely puberulent within; stamens glabrous except villous near base; style glabrous, ovary glabrous; fruit obovoid, to $13 \mathrm{~mm}$. long, glabrous, black.

This has been confused with $V$. floridula Duchass. \& Walp. of Panama, which has larger flowers and short-pedunculate cymes. It more closely resembles the West Indian $V$. divaricata $\mathrm{Sw}$. which has slightly larger flowers and glabrate pedicels and calyces. 


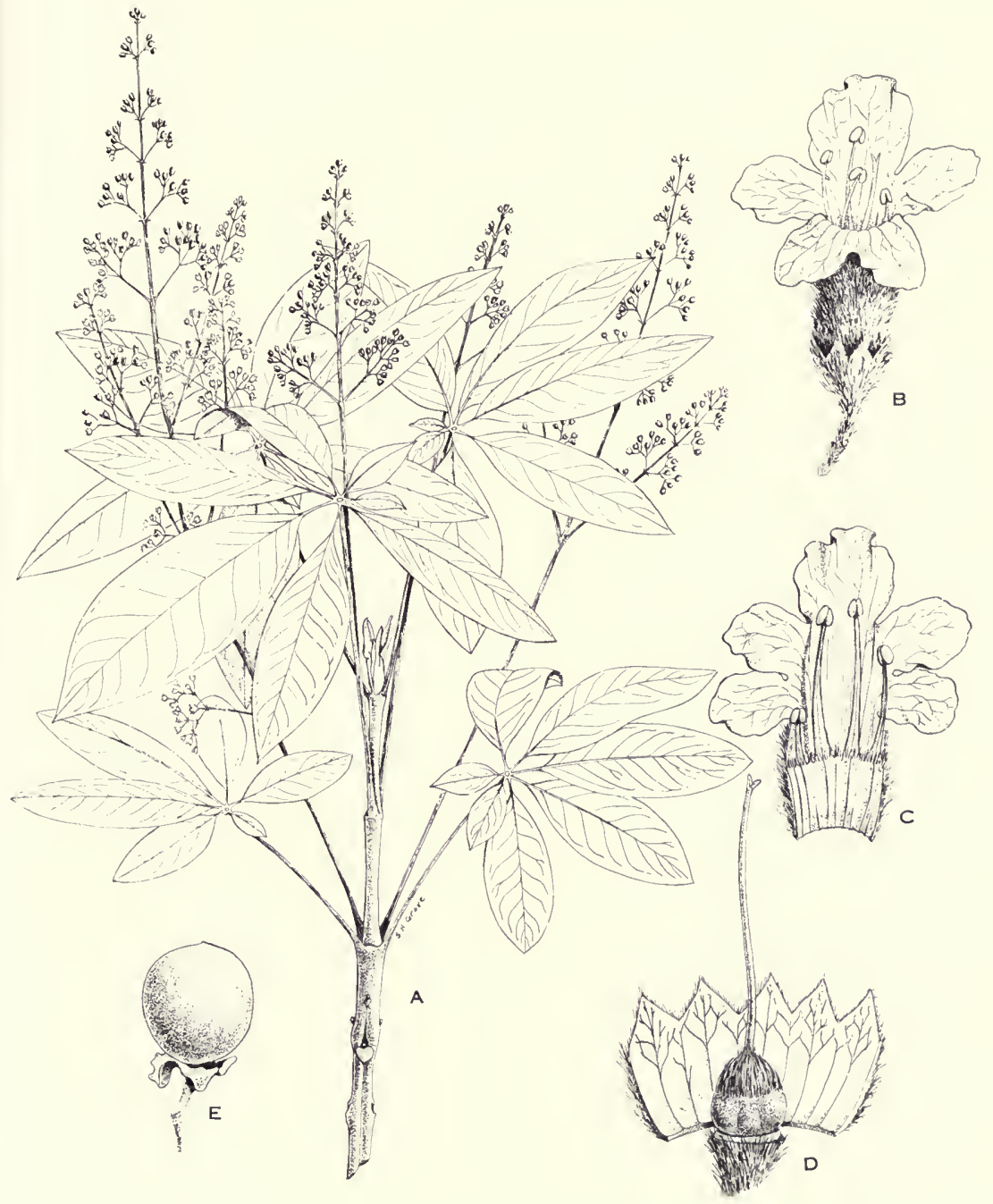

FIG. 47. Vitex gaumeri. A, section of plant with inflorescences, $1 / 2$ natural size; $\mathrm{B}$, flower, $\times 3.5 ; \mathrm{C}$, corolla dissected to show stamens, $\times 3.5 ; \mathrm{D}$. calyx opened to show pistil, $\times 3.5 ; \mathrm{E}$, fruit, $\times 1$.

It should be noted that the only two Guatemalan collections, both determined by Moldenke, are sterile.

Vitex gaumeri Greenm. Field Mus. Bot. 2:260. 1907. V.longeracemosa Pittier, Contr. U. S. Nat. Herb. 20:486. 1922 (type from Quiriguá, Izabal, H. N. Whitford \& L. R. Stadtmiller 74). Jocote de mico (Izabal); yaxnic (Petén, Maya). 
Damp forest, often on limestone, occasional on pine ridges and in poor soil, sometimes in second growth, sea level to 600 meters; Alta Verapaz; Izabal; Petén. Chiapas and Yucatan Peninsula of Mexico; British Honduras; Honduras.

Large trees, sometimes $30 \mathrm{~m}$. tall, with broad, spreading crowns, the trunks to $75 \mathrm{~cm}$. in diameter, with brown, ridged bark, the young branchlets densely puberulent, whitish; leaves on tomentulose petioles $6-16 \mathrm{~cm}$. long, leaflets 5 , rarely 7 , on petiolules $0.5-3 \mathrm{~cm}$. long, the blades chartaceous, elliptic or elliptic-oblong, mostly 6-22 cm. long, entire, acute or acuminate, usually obtuse or rounded at the base, puberulent or glabrate above, usually whitish or grayish beneath and densely tomentulose or velutinous; inflorescences axillary, cymose, in panicles $8-30 \mathrm{~cm}$. long, the flowers short-pedicellate; calyx campanulate at anthesis, patelliform in fruit, $2-3 \mathrm{~mm}$. long, densely puberulent, with 5 acute teeth; corolla blue, sparsely puberulent outside, sometimes minutely papillate, the tube $4-5 \mathrm{~mm}$. long, $2-3 \mathrm{~mm}$. wide, sparsely villous in throat, the lobes equalling or shorter than the tube; filaments of stamens pubescent, more densely so near base; style glabrous or nearly so, the ovary densely pubescent; fruits somewhat fleshy, yellow, depressed-globose, minutely puberulent, $12-20 \mathrm{~mm}$. broad.

A tree of this species from Petén was reported by H. H. Bartlett in 1931 to have been six feet in diameter. In British Honduras, it is sometimes called "fiddlewood," "blue blossom," and "matasano."

$V$. gaumeri is much like $V$. hemsleyi Briq. of Mexico, but differs in its much heavier indument and smaller flowers.

Vitex kuylenii Standl. Trop. Woods 8: 6. 1926. Barabas (Izabal).

Damp forest, sometimes in pine forest, sea level to 150 meters; Alta Verapaz; Izabal (type from Izabal, Henry Kuylen 66); Chiquimula. Southern Mexico; British Honduras; Atlantic lowlands of Honduras and Nicaragua.

Trees, 10-15 m. tall, with trunks $25 \mathrm{~cm}$. in diameter or perhaps larger, the branchlets glabrate; leaves on petioles 4-9 $\mathrm{cm}$. long, leaflets usually 5 (rarely 7), on petiolules $4-13 \mathrm{~mm}$. long, the blades chartaceous, glabrous or nearly so, of ten lustrous, entire, elliptic or oblong-elliptic, $4-20 \mathrm{~cm}$. long, acute or acuminate, acute at the base; inflorescence axillary, cymose, in long-pedunculate panicles, $10-15 \mathrm{~cm}$. long, the branches minutely puberulent; flowers short-pedicellate; calyx campanulate in anthesis, patelliform in fruit, puberulent, the tube $2-3 \mathrm{~mm}$. long, the lobes triangular-oblong to linear, subacute, $1.5-2.5 \mathrm{~mm}$. long, usually becoming reflexed; flowers fragrant, corolla light blue to purple, minutely puberulent outside, villous in throat, the tube 6-7 mm. long, 1-2 mm. wide, the longest lobe 5-6 mm. long, 4-6 mm. broad; filaments of stamens pubescent, villous near base; style pubescent, ovary densely pubescent to velutinous; fruits fleshy, yellow, depressed-globose, minutely puberulent, to $15 \mathrm{~mm}$. broad. 


Publication 1100 





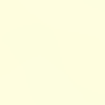

(n) 

UNIVERSITY OF ILLINOIS-URBANA

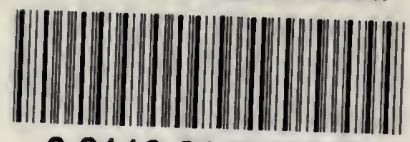
30112018259827 